\title{
The Mongols and the Armenians (1220-1335)
}

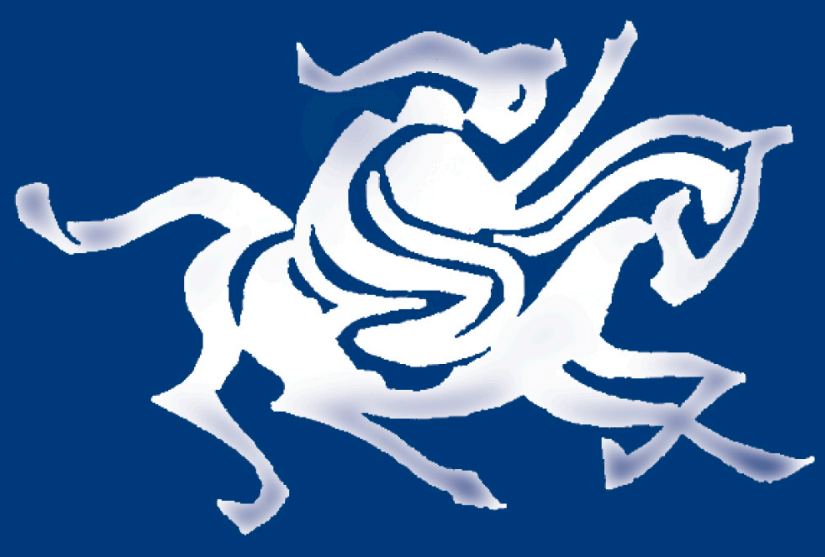

\section{B Y}

BAYARSAIKHAN DASHDONDOG

\author{
B R I L L
}


The Mongols and the Armenians (1220-1335) 


\title{
Brill's \\ Inner Asian Library
}

\author{
Editors \\ Michael R. Drompp \\ Devin DeWeese
}

VOLUME 24 


\section{The Mongols and the Armenians (1220-1335)}

By

Bayarsaikhan Dashdondog

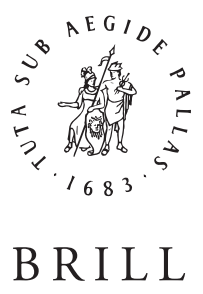


B R I L L This is an open access title distributed under the terms of the CC-BY-NC License, OPEN which permits any non-commercial use, distribution, and reproduction in any medium, provided the original author(s) and source are credited.

An electronic version of this book is freely available, thanks to the support of libraries working with Knowledge Unlatched. More information about the initiative can be found at www.knowledgeunlatched.org.

Library of Congress Cataloging-in-Publication Data

Dashdondog, Bayarsaikhan.

The Mongols and the Armenians (1220-1335) / by Bayarsaikhan Dashdondog.

p. cm. - (Brill's Inner Asian library, ISSN 1566-7162 ; v. 24)

Includes bibliographical references and index.

ISBN 978-90-04-18635-4 (hbk. : acid-free paper)

1. Mongols-History. 2. Armenians-History. 3. Mongols-Armenia-History.

4. Armenia-History-428-1522. 5. Mongolia-Relations-Armenia.

6. Armenia—Relations--Mongolia. 7. Middle East—History, Military. I. Title.

DS19.D37 2010

956.6'2014-dc22

2010042551

ISSN $\quad 1566-7162$

ISBN 9789004186354

(c) Copyright 2011 by Koninklijke Brill NV, Leiden, The Netherlands.

This work is published by Koninklijke Brill NV. Koninklijke Brill NV incorporates the imprints Brill, Brill Hes \& De Graaf, Brill Nijhoff, Brill Rodopi and Hotei Publishing.

Koninklijke Brill NV reserves the right to protect the publication against unauthorized use and to authorize dissemination by means of offprints, legitimate photocopies, microform editions, reprints, translations, and secondary information sources, such as abstracting and indexing services including databases. Requests for commercial re-use, use of parts of the publication, and/or translations must be addressed to Koninklijke Brill NV.

This book is printed on acid-free paper and produced in a sustainable manner. 
To my mother, Ichinkhorloo BATJARGAL and memory of my father, Samdan DASHDONDOG 



\section{CONTENTS}

List of Acronyms ........................... xi

Note on Transliterations $\ldots \ldots \ldots \ldots \ldots \ldots \ldots \ldots \ldots \ldots$ xiii

Note on Translations $\ldots \ldots \ldots \ldots \ldots \ldots \ldots \ldots \ldots \ldots \ldots \ldots \ldots \ldots \ldots$ xiii

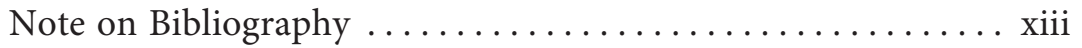

List of Maps .......................... xiii

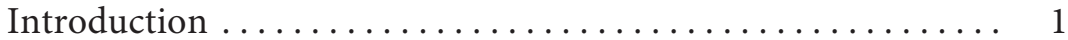

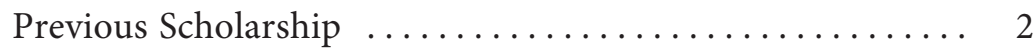

Primary Sources $\ldots \ldots \ldots \ldots \ldots \ldots \ldots \ldots \ldots \ldots \ldots$

Chapter One A Brief Historical Background of the

Armenians and Mongols ....................... 31

The Armenians in Greater Armenia $\ldots . \ldots \ldots \ldots \ldots \ldots . \ldots 31$

The Armenians in Cilician Armenia $\ldots \ldots \ldots \ldots \ldots \ldots . . . . .34$

The Mongols ......................... 37

Chapter Two Mongol Noyans in Greater Armenia (1220-1245) 43

The first Mongols in the lands of the Armenians ........ 43

The advance of Chormaghan on Greater Armenia

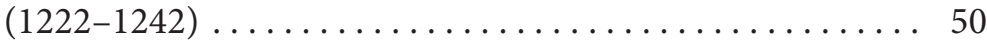

The Mongol noyans in the land of the Armenians ....... 55

The final Mongol conquest of Armenia by Baiju and its

impact on the Armenian Kingdom of Cilicia (1242-1245) ... 60

Factors that impacted the Mongol conquest of Armenia ... 66

Chapter Three Strategic Submissions by the Armenians ..... 71

Individual submissions and contacts of Greater Armenian princes with the Mongol Khans and Il-Khans ........ 71

State submission and its development: The Armenian

Kingdom of Cilicia ...................... 79

Conflicts of local interests in Greater Armenia in the 1240s-1270s ............................... 90

Other factors influencing Mongol-Armenian relations..... 93 
Chapter Four Mongol Administration in Greater Armenia (1243-1275) .............................. 99

Darughachis in Greater Armenia . . . . . . . . . . . . . 100

Mongol census-taking in Greater Armenia . . . . . . . . . . 107

Tributes and Taxes ....................... 111

Chapter Five Mongol-Armenian Military Cooperation:

Stage I: The Conquest of the Middle East (1258-1260) . . . . 121

Hülegü (r. 1256-1265) and the Greater Armenian forces

against the Muslim supremacies . . . . . . . . . . . . 122

The Mongol penetration into Upper Mesopotamia . . . . . . . 132

The implementation of a Cilician Armenian dream . . . . . 135

Chapter Six The Il-Khans' Wars and Mongol-Cilician

Armenian Collaboration: Stage II (1260-1265). . . . . . . . . . . 143

Joint ventures of Hülegü and Het'um I in Syria . . . . . . . . 143

The participation of the Armenians in the Il-Khanid war

against the Golden Horde ... . . . . . . . . . . . . . . 149

Chapter Seven Mongol-Armenian Cooperation: Stage III (1265-1295) ..................................... 159

The strongest pairing of Abaqa and Het'um I against

Baybars ........................... 160

Greater Armenia and the struggle with the Golden Horde . 166

Lewon III and Abaqa against Baybars .............. 169

The Mongols' appeal to Latin Christendom . . . . . . . . . . 171

Mongol-Armenian relations in the time of Tegüder Ahmad

(r. 1282-1284) ......................... 175

The second pairing of Arghun and King Lewon III against

Sultan Qalāwūn . . . . . . . . . . . . . . . . . . . . . . . . . . . . . . 179

The weakest link: Het'um II and the Mongol Il-Khans:

Geikhatu (r. 1291-1295) and Baidu (1295) ........... 184

Chapter Eight The End of Mongol-Armenian Relations (1295-1335)

The last chance to save the alliance: Het'um II and the

Il-Khan Ghazan (r. 1295-1304)

The vanquished Armenian hope: Öljeitü (r. 1304-1316) and

his Armenian counterparts ................. 203

The aftermath of cooperation: Lewon V (r. 1320-1341/1342)

and Abū Sa'ìd (r. 1316-1335) ................. 208 


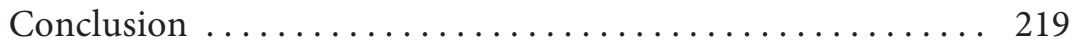

Dynastic Tables ............................. 227

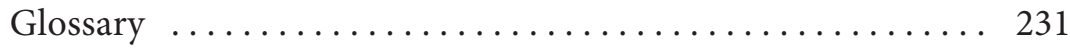

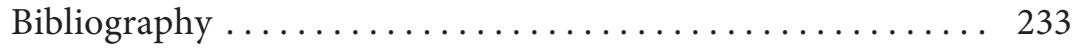

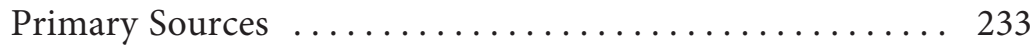

Secondary Literature $\ldots \ldots \ldots \ldots \ldots \ldots \ldots \ldots \ldots . \ldots \ldots$

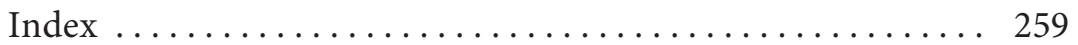





\section{LIST OF ACRONYMS}

AOASH

BSOAS

CAJ

CIA

E-ASPAC

EB

EI

IAMS

IJMES

JESHO

JRAS

JSAI

JSAS

JTS

HAP

HJAS

MNT

OCD

OUD

REA

RHC/DA.

RHC/OR. Recueil des Historiens des Croisades. Historiens Orientaux

SHM

SOAS

Acta Orientalia Academiae Scientiarum Hungaricae Bulletin of the School of Oriental and African Studies Central Asiatic Journal

Corpus Inscriptionum Armenicarum (Divan Hay Vimagrut'yan)

Electronic Journal in Asian Studies on the Pacific Coast

Encyclopaedia Britannica

Encyclopaedia of Islam

International Association for Mongol Studies

International Journal of Middle East Studies

Journal of the Economic and Social History of the Orient

Journal of the Royal Asiatic Society

Jerusalem Studies in Arabic and Islam

Journal of the Society for Armenian Studies

Journal of Turkish Studies

History of the Armenian People

Harvard Journal of Asiatic Studies

Mongolyn Nuuts Tovchoo (The Secret History of the Mongols), classical text

Oxford Classical Dictionary

Oxford Universal Dictionary

Revue des Études Arméniennes

Recueil des Historiens des Croisades. Documents

The Secret History of the Mongols, trans. Urgunge Onon, Curzon, 2001

School of Oriental and African Studies 



\section{NOTE ON TRANSLITERATIONS}

The Armenian transliteration has followed the convention used in JSAS, except that $\cap$ is transcribed R. For Arabic and Persian, the English transliteration system used in IJMES is followed, except ض is D for Persian. For Mongolian, the system of Vladimirtsov's Comparative Grammar is adopted, except Q replaces $\mathrm{KH}$ in some words that are already established with Q in English, like Quriltai instead of Khuriltai; SH replaces Š, and GH replaces $\gamma$.

Well-known places and names are given in their accepted English forms, in some cases in parenthesis along with the forms that are found in the original sources.

\section{NOTE ON TRANSLATIONS}

The extracts of the sources, especially from Armenian, quoted in this study are translated by the author of this work, unless a particular translated edition is indicated.

\section{NOTE ON BIBLIOGRAPHY}

The titles of Armenian primary sources are given in Armenian along with the first names of authors as far as possible.

\section{LIST OF MAPS}

1. Caucasia in the $12-13$ th century $\ldots \ldots \ldots \ldots \ldots \ldots \ldots$ xiv

2. Armenian Kingdom of Cilicia $(1199-1375) \ldots \ldots \ldots \ldots$ xv

3. The Mongol Empire ..................... xvi

4. The Mongols Noyans in Greater Armenia ........... xvii

5. The Mongols in the Middle and Near East ......... xviii 


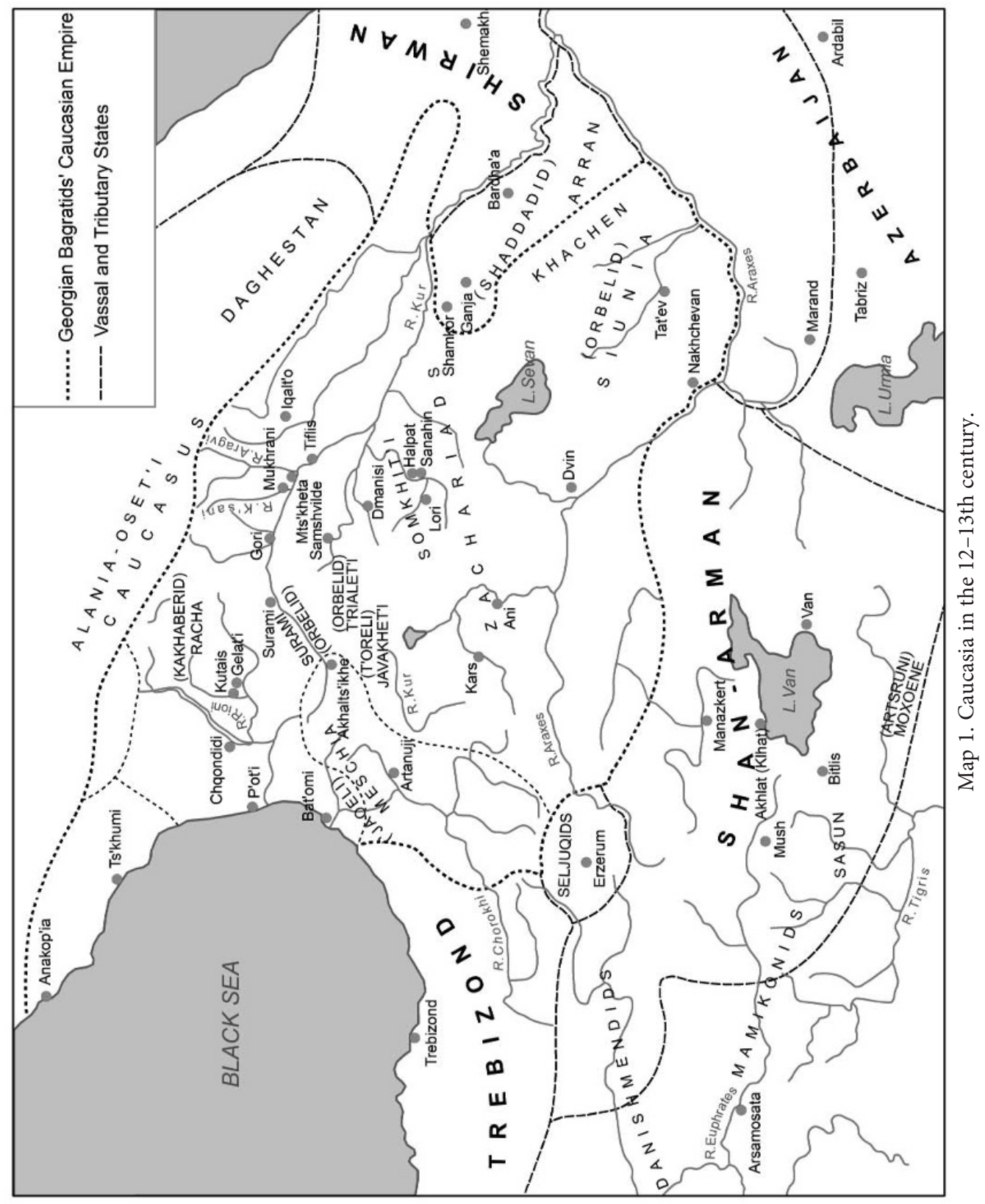




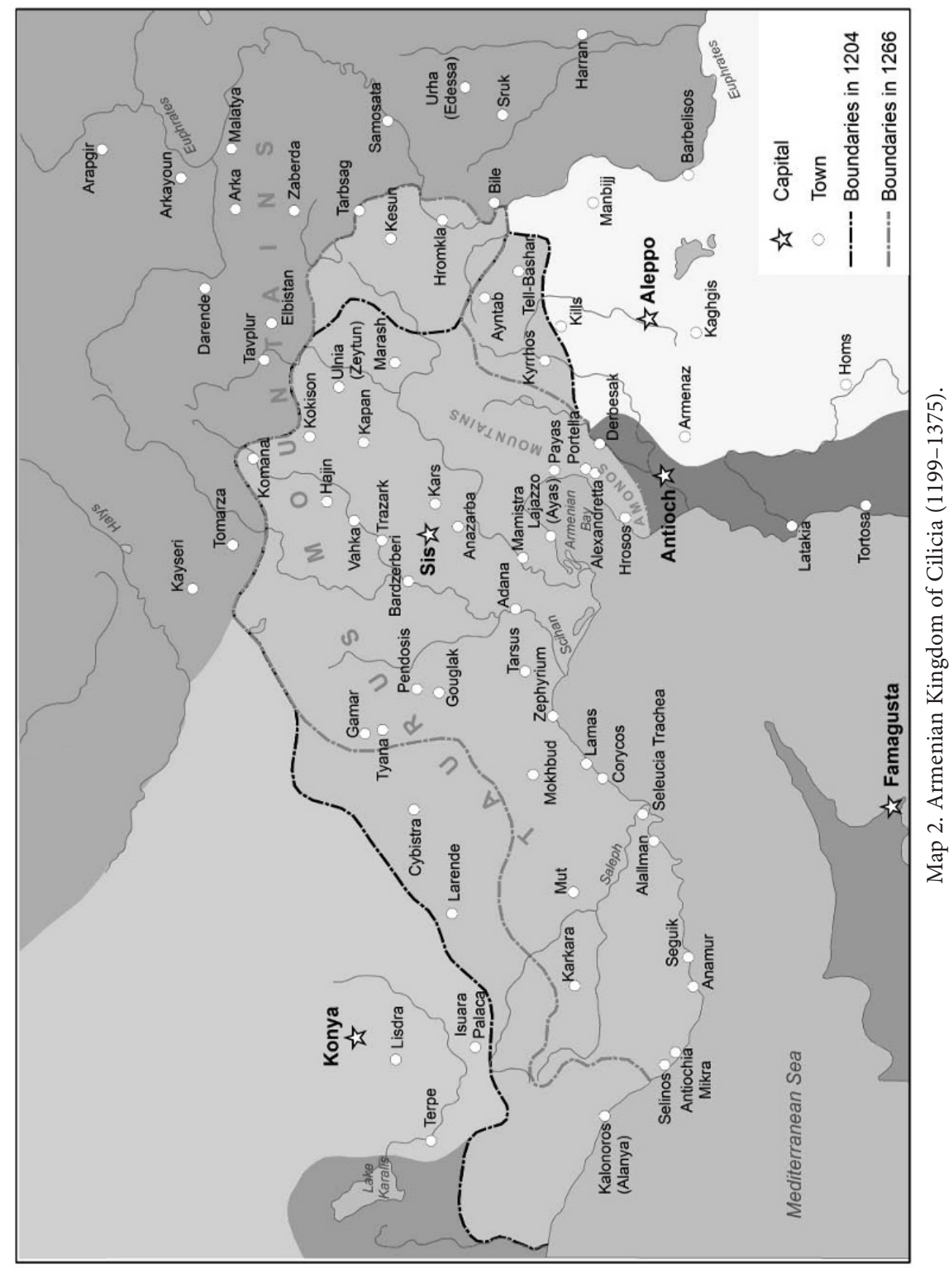




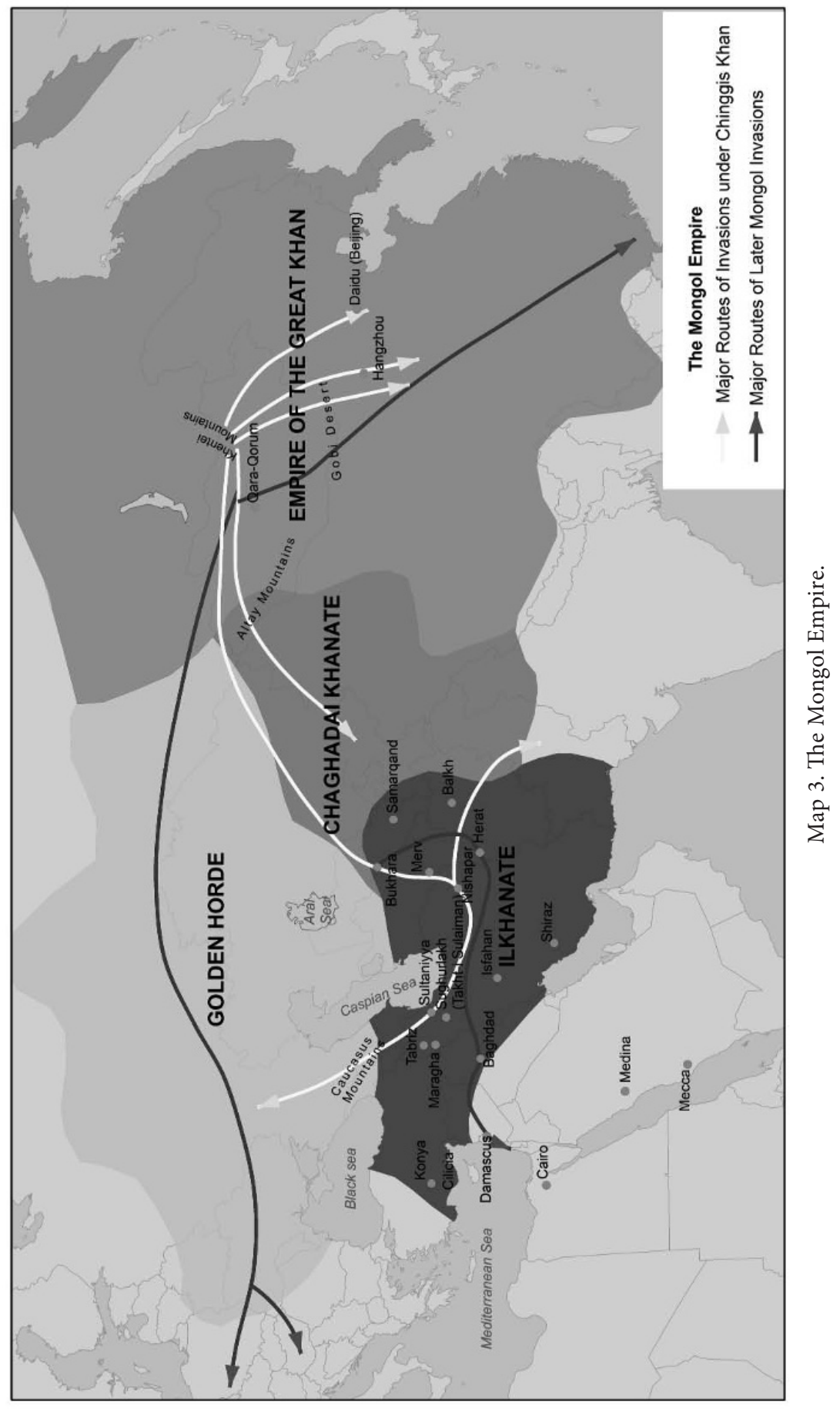




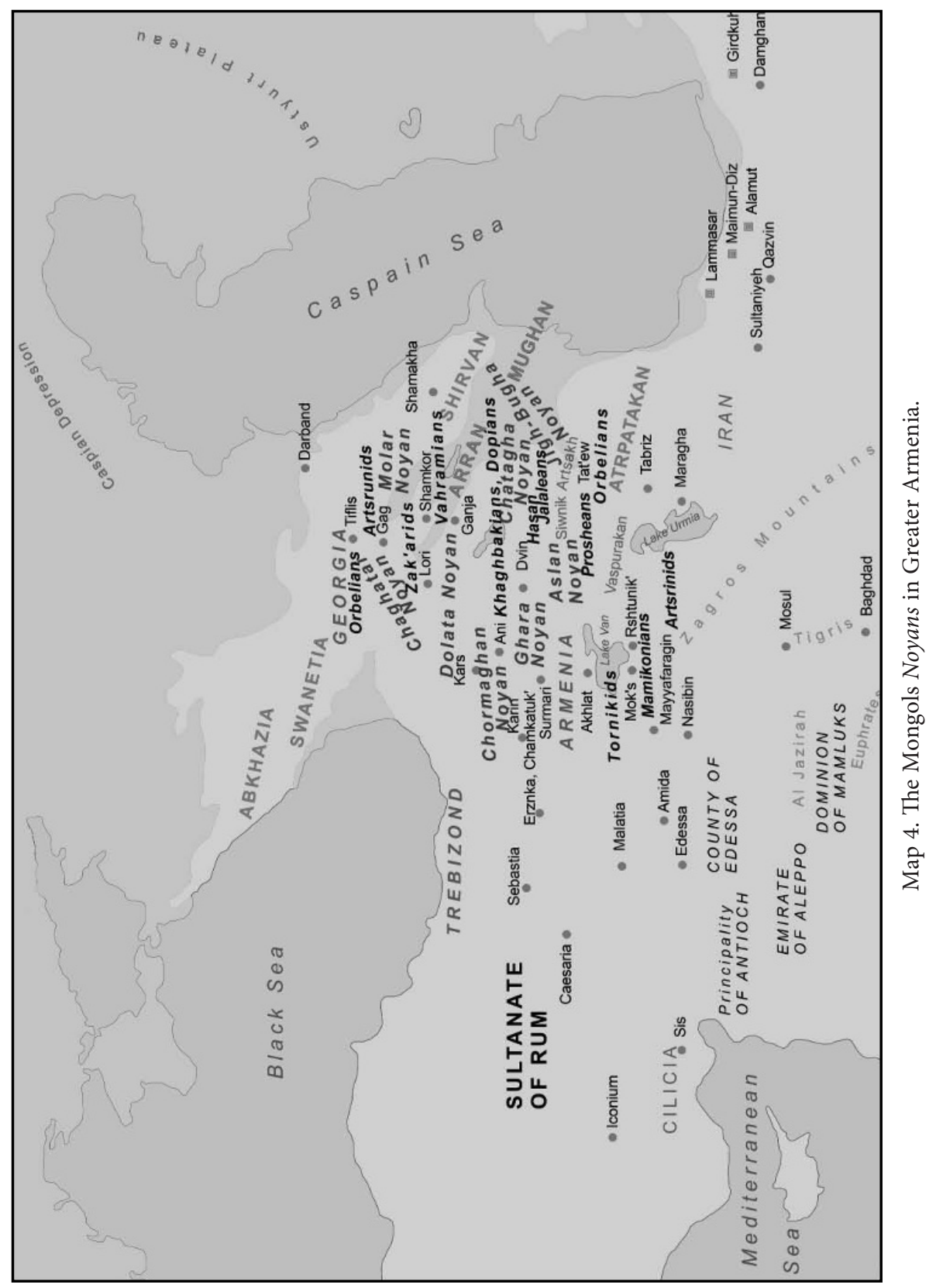




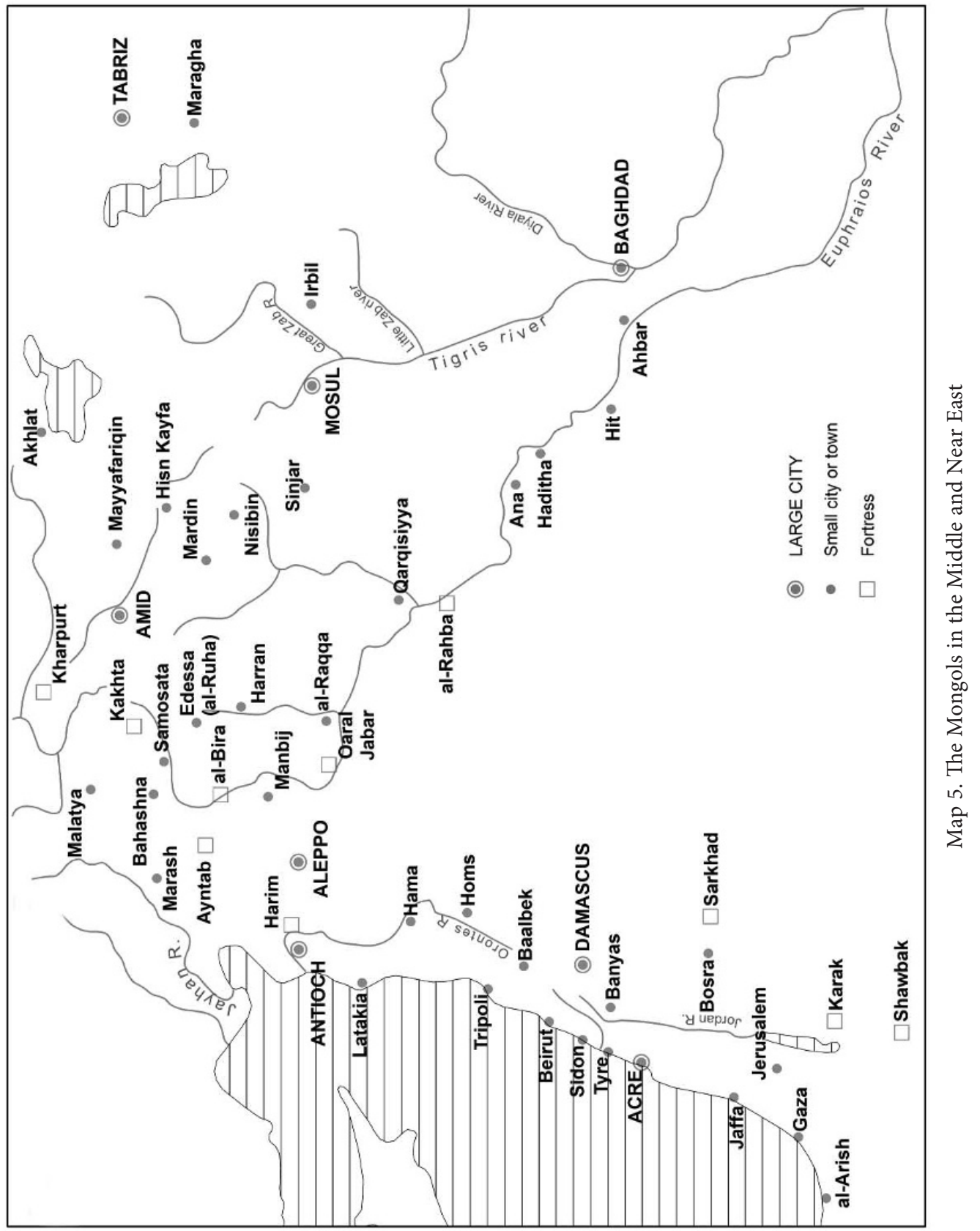




\section{INTRODUCTION}

This book is an invitation to a journey to the medieval world, which, in author's opinion, is the most picturesque period of human history to embark back to, and it is definitely one of the fascinating moments of the Great Mongol Empire. It is an interesting journey in many ways: historically, geographically and culturally. It will take the reader from the Inner Asian plateau to the Caucasus, Anatolia, Middle and Near East; from a nomadic culture to sedentary civilisations; from a warrior's mindset to the subjects' survival policy.

The present work tries to understand the connection between the various aspects of East and West in Medieval times by exploring relations between two nations, the Armenians and the Mongols, who began interacting with each other during the thirteenth century. During that time the Mongols became widely known to the world for building the most extensive land empire in human history that stretched from the Pacific Ocean to the Adriatic Sea, covering most of Asia all the way to Korea, excluding India and Eastern Europe, but including Hungary.

Conceptualising the Mongol conquest, Armenian historian Grigor Aknerts' $i$ named the Mongols a 'Nation of Archers.' The phenomenon of the Mongol Empire has become the subject of extensive recent academic publications. ${ }^{1}$ The relationship of the Mongols with their subject peoples still remains the chief area of interest among modern scholars. Likewise, this book explores the relationship between the Armenians and the Mongols during the thirteenth and fourteenth centuries, which was developed quite differently between the Mongol Empire and Greater Armenia on the one hand, and between the Mongol Empire and the Armenian Kingdom of Cilicia on the other. The fact that part of Greater Armenia, having been conquered before by the Georgians, tried to sustain its sovereignty through the individual contacts of the Armenian princes with the Mongol conquerors, illustrates one pattern of their relations. Another pattern of the

\footnotetext{
${ }^{1}$ We are indebted to the fairly recent works and valuable expertise of Thomas Allsen on cultural exchanges within the Mongol Empire, Reuven Amitai on Mongol and Mamluk relations, Peter Jackson on the relations between the Mongols and the West, David Morgan on the Mongols' rule and administration, Christopher Atwood on the Mongol Empire, and many others.
} 
Mongol-Armenian relationship was the accepting of tributary status by the Armenian Kingdom in Cilicia without suffering Mongol assaults. In both cases, the Armenians entered into direct contact with the Mongols: The Greater Armenians acted as subjects of the Mongols to assist the latter with further conquests of the Middle East; the Cilician Armenians, being vassals, participated in conquests as the Mongols' partners, thus both of them enhanced Mongol imperial ideology. As such, the Cilician Armenians not only played an essential role as a Mongol ally, but also contributed to the Mongol conquest of the Near East, intending to liberate the Holy Land, bringing into political and religious confrontation the Christian West, the Mamluk Sultanate and the Mongol Il-Khanate.

Based on the political course of the conquest and the actual presence of the Mongols in Armenian lands, the book aims to illustrate that without local political ties it was impossible to rule the vast domain and the interactions of the Mongol commanders with the Greater Armenian princes brought gains for both parties. Besides this, the basis of Mongol administration, which dealt with the complex issues of taxes and tributes of nomadic origin, was introduced to the sedentary society of Greater Armenia. These affairs represented a completely new challenge for nomads, as the guiding principle of acquiring booty was no longer viable; awareness of this among the Mongol rulers led to the establishment of economic institutions instead. The physical participation of the Greater Armenians in Mongol wars and the actual co-operation of the Cilician Armenian monarchy in Mongol conquests were challenged in stages, since the breakdown of the issues of Mongol-Armenian cooperation was applied until the last Il-Khan. These themes form the subject of this book and which I aim to achieve through the study of primary sources written in Mongolian, Armenian, Persian and Arabic, together with additional literature written on the subject.

\section{Previous Scholarship}

Despite extraordinary geographical mobility and ethnic-cultural diversity of the Mongol Empire as a subject for study, research on the Mongols and Armenians is relatively meagre and has generally been undertaken only in the light of the damage brought by the Mongols to Greater Armenia. The reasons for this are twofold. First, 
the historical events are often evaluated only in the light of local conditions. Second, the sources are sometimes biased to conform to the ideology of a particular time. Since the studies of the Mongols are based on what was written by their vassals, most of the information about the conquerors and their image is understandably more negative than positive. However, my approach is to look at the issues relating to the Armenians as part of the larger framework of the Mongol Empire and to highlight their role in Mongol affairs, which was made possible by direct access to a range of sources.

Indeed, there is substantial modern scholarship on the subject of the Mongol invasion of Armenia; however, their influence is usually addressed as 'destruction.' The Soviet scholar H. Manandian was no exception when exploring the subject in depth as a separate topic in the third volume of his K'nnakan Tesut'iwn Hay Zhoghovrdi Patmut'yan (Critical View of the History of the Armenian People) in 1952. The main consideration of this work concerning the Mongol period in Greater Armenia is tackled as a dismal moment in the history of Armenia. His statement that the Armenians and Georgians were at a much higher level of social development than the Mongols and that the Mongols were unable to alter the social formation of the Armenians was possibly dictated by the ideology of the time when the work was written. ${ }^{2}$ Regardless of the fact that Manandian believes that the Mongol nomads impeded Armenian culture by their ferociousness, his detailed study of the initial Mongol conquest of Armenia, the locations and names of the battlefields, and the economic issues of the country, especially regarding the trade circumstances under the Mongol governors, are worth consulting.

This seems to be a common approach taken by Soviet scholars in seeing the Mongols only as a regressive force. The second volume of the Sketches of the History of the USSR, edited by Grekov in 1953, which covers the medieval period and relates to the issues of this study, is also biased by Soviet ideology, comparing the Mongol invasion with a huge devastating machine that halted the progress of the world. Surely, a polity of a 'Tartar Yoke' existed. A definition of this kind is the most common; however, as every human is equally cultural, it limits the issues of cultural transmission of the Mongol Empire, becoming a popular subject for recent research. ${ }^{3}$ In favour

\footnotetext{
2 Manandian, 1952:245.

Allsen, 2001:5.
} 
of Grekov's work, his approach in highlighting the local conditions under Mongol dominion in each region of the former Soviet territories is of value. Of greatest interest, the economic conditions of the Caucasus region, including Greater Armenia, are examined in depth to demonstrate the damage brought on by the Mongols. However, it is clear that the volume uses a range of primary Armenian sources, unfortunately without mentioning them in most cases.

Another prominent work, the Social Economic and Political History of Armenia in the 13th-14th Centuries by L. Babayan, written in 1969, as well as his chapters on the Mongol period in Greater Armenia in the third volume of Hay Zhoghovrdi Patmut'iwn (The History of the Armenian People) written in 1976, remain the basic works to consult, although they are not free from Marxist-Leninist ideology either. Nevertheless, Babayan has extensive references to the primary sources of the Armenian Houses and their history. Moreover, he made a comparative study of Armenian and Persian sources to find out that Armenian authors, such as Kirakos Gandzakets'i, Vardan Arevelts'i and Step'annos Orbelian, were known to Rashìd al-Din, a discussion of which follows below in the section on the sources.

Although indebted to the Soviet period, A. Galstyan has a different approach to the ones mentioned above. In his Armjanskije istochniki o Mongolakh (Armenian Sources for the Mongols), written in 1962, he examines the primary Armenian sources with an aim to demonstrate that, in their writings, Armenian historians shared more sympathy with the Mongols and particularly with the development of Mongol-Armenian relations. The essential point in assessing Galstyan's work remains the fact that he is inclined to confirm the possible existence of the actual document of the Mongol-Armenian agreement of cooperation, mentioned by Het'um Patmich' (Hayton). Therefore, he makes extensive references to this document in his Russian translation, based on the French and Latin texts. ${ }^{4}$

Another point of view is expressed by R. Bedrosian in his doctoral dissertation "The Turco-Mongol Invasions and the Lords of Armenia in the 13th-14th Centuries" in 1979 needs to be acknowledged as a meticulous work. However, Bedrosian tends to see the Mongols or external factors as a main motive in the decline of the Armenian

${ }^{4}$ Galstyan, 1962:124-126 (n.164). 
Houses, although this process of the failing powers of the princely Armenian Houses started much earlier.

The Armenian Kingdom of Cilicia has been studied by a number of scholars in connection with the history of the Armenians or with the Crusades and the history of Byzantium. The works by W. RudtCollenberg, ${ }^{5}$ T. Boase, ${ }^{6}$ C. Mutafian ${ }^{7}$ and G. Dédéyan ${ }^{8}$ have contributed greatly to the study of the political history of Cilician Armenia, its internal and external affairs, and its involvement with the Mamluks, Crusaders and Il-Khans. In particular, S. der Nersessian's textual study of the different editions of Smbat Sparapet's Chronicle known as the Royal Chronicle, ${ }^{9}$ along with the partial translation into English, needs to be acknowledged. Her edition of the Chronicle discovered an important detail regarding the reason of the Mongol failure in Syria in 1260; this was explained by the excessive heat of the place and sickness among the Mongol horses. ${ }^{10}$

With the invaluable scholarship of R. Amitai and A. Stewart, the extensive Arab sources could be tackled in this study in which the dynamics of Mongol-Mamluk relations and Mamluk-Cilician Armenian affairs are highlighted. ${ }^{11}$

Peter Jackson's assessment of Western sources for the Mongols and especially his opinion of the Cilician Armenian source of Hayton written in 1307 inspired this study to look at the reasons where and for whom the primary sources were written. ${ }^{12}$

Recent research on the Mongols through Syriac sources by Pier Giorgio Borbone, as well as an apologetic view of the facts and their interpretation for a Muslim and Christian readership in Bar Hebraeus by Denise Aigle, should be also mentioned. ${ }^{13}$

A wide range of modern Western and Russian scholarship on the recent and early period was consulted with regard to the Mongols, Armenians, Mamluks and the Crusades. In addition to these, the use

\footnotetext{
${ }^{5}$ Rudt-Collenberg, 1963.

6 Boase, 1978.

Mutafian, 2001.

Dédéyan, 1996.

9 Der Nersessian, 1973.

10 Ibid., 370.

11 Amitai, 2004, 2005; Stewart, 2001.

12 Jackson, 2005a.

13 Borbone, 2004, 2005, 2006; Aigle, 2005:87-107.
} 
of the works of Mongol scholars, such as Sh. Bira, ${ }^{14}$ B. Shirendyb, ${ }^{15}$ Ch. Dalai, ${ }^{16}$ Sh. Choima ${ }^{17}$ and S. Dulam ${ }^{18}$ is brought into focus, some for the first time, further enhancing scholarship on the Mongol Empire. The main arguments of this study comment on these modern scholars and their hypotheses, and will be presented in due course.

\section{Primary Sources}

The information from different historiographical traditions is often contradictory and varies according to their views of certain historical events, which are based on their culture, locality, time and style of writing, as well as the character of the sources. While reading primary sources in the original is important, it is not enough. It is crucial to understand the patterns of thought of medieval Armenians, Mongols and the neighbours who wrote about them.

Since there are no sources compiled by historians of the Mongol dynasty for the Armenians, the issues connected with the MongolArmenian relationship are mainly based on what the Armenians and others chose to mention in their historiographical traditions. However, comparative reading of a large variety of contemporary sources allows a reconstruction of the details of historical events that can build a distinctive picture of the relationship between Mongols and Armenians in the thirteenth and fourteenth centuries. For that reason, the object of this study is to bring together essential knowledge of contemporary Armenian sources for the Mongols. The overall impact of this study is to add one more dimension to understanding the relationships established between the conquerors and their subjects in the Mongol Empire.

\section{Mongolian Sources}

The Mongolian sources are limited to the Secret History of the Mongols (Mongyol-un Ni iuča Tobčiyan), the only surviving text,

\footnotetext{
${ }_{14}$ Bira, 2002, 2006.

${ }_{15}$ Shirendyb, 1966.

16 Dalai, 1992.

17 Choimaa, 2007.

18 Dulam, 1999.
} 
translated into many languages and several times into English. ${ }^{19}$ The existence of this single source tends to be explained by the claim that the Mongols were illiterate before the time of Chinggis Khan and even after his reign. ${ }^{20}$ If this is a plausible view, how could these supposedly illiterate people have produced at their first attempt such a significant work of historiography, literature and style as the Secret History of the Mongols ${ }^{21}$ Professor Kara implies that the writings of the Uighurs from the ninth century and of the Kidans (Khitans) of the tenth and eleventh centuries, who were a Mongolic-speaking people that inhabited the southern region of Mongolia, were already known. ${ }^{22}$ The Kidan words that are preserved in Chinese transcription, mostly in the Liao Shih (The Annals of the Liao Dynasty) compiled by the Mongolian historian $\mathrm{T}^{\mathrm{t}} \mathrm{o}-\mathrm{t}^{\mathrm{t}} \mathrm{o}$, helped to determine the role of the Kidan language among the Altaic languages. ${ }^{23}$ The existence of Sogdian borrowings in the Mongolian language shows that the Mongols adopted the Uighur script in the early period of the Uighur state. ${ }^{24}$ Recent linguistic research by Ts. Shagdarsurung shows that the Mongols borrowed their alphabet not from the the Uighurs, but from the Sogdians directly and simultaneously as the Uighurs did. ${ }^{25}$ The Sogdian-Uighur script, that goes back to the PhoenicianAramaic system of writing, was used in its fully-fledged form in the chancellery practice of the Mongol state. ${ }^{26}$ Moreover, it is attested that the Uighurs used the Orkhon script. ${ }^{27}$ This script is named after the Orkhon valley in Mongolia.

The fact that there are no other extant works at our disposal does not indicate the illiteracy of the Mongols. The royal chronicles that were kept at the courts of the Khans were not permitted to be on public display, so the histories were called Secret and the books

19 The Secret History of the Mongols was translated by Cleaves in 1982; by Onon Urgunge in 2001; and the most recent English translation with a historical and philological commentary was done by I. de Rachewiltz in 2004 in two volumes.

${ }^{20}$ Morgan, 1990:9.

${ }^{21}$ Bira, 2002:40-42.

${ }^{22}$ Kara, 2005:7.

${ }^{23}$ Ibid., 8-9. The Liao Dynasty ruled over Manchuria, Mongolia and northern China from 907 until 1125.

${ }^{24}$ Okladnikov, 1983:116.

25 Shagdarsurung, 2001:25.

${ }^{26}$ Bira, 2001:345.

27 Shirendyb, 1966:95. 
Golden. ${ }^{28}$ It is obvious that at the time of dissolution of any rule, the royal chronicles, glorifying the deeds of former rulers, would be targets for destruction as much as their court or their leader. Therefore, it is more prudent to assume a loss of sources rather than supposed illiteracy. With regard to the limitation of the written sources in Mongolian, some scholars suggest that knowledge of Mongolian is the least important among the wide range of languages for the study of the Mongol Empire. ${ }^{29}$ Considering the fact that the Mongols were nomads whose lifestyle was not conducive to written activity, one surely cannot ignore their oral tradition and insights, nor their 'nomadic historiography,' knowledge of which can be gained only through knowing the language. ${ }^{30}$

The name of the author of the Secret History of the Mongols is not known. ${ }^{31}$ It was written in the Year of the Rat (1228/1240/1252). ${ }^{32}$ Agreeing with Ozawa, I tend to believe that the first ten chapters were completed in 1228 and, as historical events show, the last two chapters might have been added later. In 2004, a group of Mongolian scholars re-produced the classical text of the Secret History of the Mongols that consists of 12 chapters and 282 paragraphs. This edition does not resolve the issue of the authorship, nor the date of the

28 A copy of the Altan Debter (Golden Book/Register) was at the disposal of Rashìd al-Dīn at the Il-Khanid court and was in circulation at the Mongol court in China (Allsen, 2001:88).

${ }^{29}$ Morgan, 1990:6.

${ }^{30}$ The epics, and other üligers, orally-transmitted epic stories in verse, constitute a bulk of narratives. For instance, Chinggisyn Er Hoyor Zagalyn Tuuj (The Story of Chinggis Khan's Two Horses), is a very famous story of the horses that Chinggis Khan abandoned after his victory over his enemies. Chinggisyn 9 Örlögtei Önchin Huugiin Tsetselsen Shastir (An Orphan Child's Debate with 9 Commanders of Chinggis Khan) tells of a child who shamed the renowned generals of Chinggis Khan by his wise advice. Both these narratives had morals that show the value of simple things or behaviour, Mongolyn Uran Zohiolyn Deejis, 1959:39-42, 60-68.

${ }^{31}$ There are disputes regarding the author of the Secret History of the Mongols. The most recent study on dating the Secret History was done by I. de Rachwiltz (2008:150-184). Ozawa denies the authorship of Shikhi Khutugtu claimed by Professor Haihish. According to Ozawa, the writer of the first ten chapters of the work was a representative of the Borjigin tribe or of the Altan Urag (Golden Clan). He argues that the writer was probably from the Ögedeids. The remaining two chapters were written by representatives of the Toluids (Ozawa, 2002:110-138).

${ }^{32}$ MNT, 2004:100. The date of composition of the work is disputed as well. Among the possible Years of the Rat $(1228,1240$ or 1252), scholars incline to 1228 (Rachwiltz) and 1252 (Atwood) as the more plausible years (see Ozawa, 2002:91108; Atwood, 2007:1-48; Rachewiltz, 2008:150-184). Bira considers that the Secret History of the Mongols was probably written between 1228 and 1240 (Bira, 2001:345). 
composition; however, it suggests that there is no discrepancy in style or language within the work as a whole. This edition provides some clarification as to the names and tribes of the Mongols, and of geography and locations. Since the Chinese characters of the surviving text had a corrupted transliteration, the rules of classical Mongolian were adopted in transcribing not only the Mongolian words, but also the poetic insertions that are so distinctive in the text.

The Secret History of the Mongols begins with the mythical origin of the Chinggisid house from Börte Chino (Blue Wolf) and Goa Maral (Beautiful Doe) in legendary times and continues until the reign of Chinggis Khan's first successor, Ögedei Khan (r. 1229-1241). The work can be divided into three parts: the genealogy of the ancestors of Chinggis Khan; narrations of his life and deeds; and short references to Ögedei Khan. The main emphasis is found in the second part, where accounts are given of historical events and data. ${ }^{33}$ This is the only surviving major source that expresses a Mongol perspective on the Mongol conquest and it is important for this study as it provides a chance to compare the relevance of its contents with other contemporary sources written by non-Mongols in the same period.

Among the lost annals was a written work called Ünen Teüke (True Annals). ${ }^{34}$ This work was a detailed chronicle of the deeds of the Mongol Khans. Professor Dalai suggests that the lost True Annals was mostly a continuation of the Secret History of the Mongols; however, in style it follows the canon of Chinese chronicle composition and it was written in both the Mongolian and Chinese languages. ${ }^{35}$ The existence of such a book is mentioned in the Yüan Shih. ${ }^{36}$

Besides this, among the lost written works was the above-mentioned Altan Debter (Golden Book), which was circulated at the Mongol courts in Iran and China. The Great Register of Qara-Qorum, another work written in Mongolian and mentioned in the Yüan Shih, was used to compile the latter. ${ }^{37}$ The Čayan Teüke (White Annals) that was in circulation during the fourteenth century was published

\footnotetext{
33 Bira, 2001:345.

34 Dalai, 1992:9.

35 Ibid., 9.

36 Yüan Shih, 1978 (\$171, 103).

37 Dalai, 1992:10.
} 
in 1981 in Inner Mongolia. ${ }^{38}$ The authorship of the White Annals is attributed to Qubilai Khan. It has 151 pages, with the narration following the tradition of Buddhist sutras. Dalai suggests that this book was probably written in the 1280s-1290s, and it relates to the biography and history of the Mongol Great Khans until the reign of Qubilai Khan. ${ }^{39}$ Bira suggests that the White Annals was written in the 1260 s-1280s. ${ }^{40}$

Another Mongolian source, written, however, in Tibetan, is the Marbo (Red Book). ${ }^{41}$ It was compiled in 1363 by Tsalba Gungaadorj (1309-1365) and it took him 17 years to complete; it has not yet been translated into other languages. The Sheng-wu Ch'in-cheng lu (Description of the Personal Campaigns of the Holy Martial) attributed to Tsagaan, written in Chinese in the thirteenth century, was considered to be a copy of the Altan Debter. ${ }^{42}$ However, recent scholarship claims that this work is not a copy, but an independent work that depicts the world conquest of the Mongols. ${ }^{43}$ To my great disappointment, the framework of my work and the language barrier did not allow me to consult these sources.

\section{Armenian Sources}

The twelfth to thirteenth centuries formed one of the richest periods in Armenian historiography, giving rise to more than ten historians and chronologists, like Samuel Anets' $i$, Mkhit'ar Anets'i, Matheos Urhayets'i, Mkhit'ar Ayrivanets'i, Vardan Arevelts'i, Kirakos

${ }^{38}$ Arban Buyantu Num-un Čayan Teükhe (White History of the Doctrine Possessing the Ten Virtues) (Köke-Qota, 1981).

${ }^{39}$ Dalai, 1992:10-11.

${ }^{40}$ Bira, 2001:399. The book was translated into German by Klaus Sagaster in 1976.

${ }^{41}$ Choimaa suggests that Luvsandanzan in his Atan Tobchi borrowed an extract on the son of Behir Bahatur, which is not found in the Secret Histories, from the Red Book by Tsalba Gungaadorj and from the Blue Annals (Devter Ombo) written in 1476-1478 by Shonnubal. Gungaadorj, in turn, mentioned that the section of the lineage of the khans was taken from the Mongolian source of 'Great Annals' (Choimaa, 2006:38).

${ }^{42}$ A comparison study of the first chapter of Yüan Shih, entitled Taizu Shilu (Biography of Tai Tzu), composed in 1303 with Sheng-wu Ch'in-cheng lu, shows that these sources have much in common with the Jämi al-Tawarikh (Compendium of Chronicles) by Rashīd al-Dīn. Moreover, Sheng-wu Ch'in-cheng lu likely was a basis for the Altan Debter, while the latter was a source for Jāmi al-Tawarikh (Choimaa, 2007:17-21).

${ }^{43}$ Dalai, 1992:11-12; Bira, 2002:72-75. 
Gandzakets'i, Grigor Aknerts'i, Vahram Rabuni, Smbat Sparapet, Het'um Patmich', Step'annos Orbelian, etc. This study uses Armenian sources of the thirteenth and fourteenth centuries where the information on the Mongols is extensive. However, Armenian sources for the Mongols differ in their attitudes towards the Mongols, expressing both neutral and personal views and depending on where they were written, i.e., in Greater Armenia or in Cilician Armenia. Of the many primary sources consulted, the most important sources with direct access to Mongol-Armenian relations will be treated below according to the chronological order in which they may have been written or compiled.

The essential source for this study remains the Patmut'iwn Hayots' (History of the Armenians) by Kirakos Gandzakets'i (1200-1271) which has 65 chapters that review the political history of Armenia from its Christianisation until 1266/1267. ${ }^{44}$ It has several thematic sections, such as political history and biographical accounts of clerics in Greater and Cilician Armenia, as well as in Caucasian Albania. Much of this work is devoted to the events of the historian's own day: The Mongol invasion and Mongol domination. From Chapter 11 onwards, Kirakos Gandzakets'i gives an extensive and in-depth account of the Mongols, starting from the emergence of the Mongols in the lands of Greater Armenia, Georgia and then in Cilician Armenia. The reason for this is that, in 1236, Kirakos was captured along with his teacher Vanakan Vardapet ${ }^{45}$ by the Mongol commander Molar in a village called Lorut, south of Tavush Fortress, where they had taken shelter from the Khwārazmian onslaught. On Molar's order, Kirakos was taken to serve the Mongols' secretarial needs, writing and reading letters during the whole of the Summer of $1236 .{ }^{46}$ This gave him a certain understanding of the history and

${ }^{44}$ In 1961, K. Melik' Ohanjanyan published a complete critical edition of the work. The work was translated into French by E. Dulaurier in 1858 (extracts only), by M. Brosset in 1870, into Russian by T. Ter-Grigorian in 1946 and A. Khanlarian in 1976, and into English by R. Bedrosian in 1975/1986. For details on various editions and translations, see Thomson, 1995:141-142; Greenwood, 2007:245-246.

${ }^{45}$ Vanakan Vardapet or Yovhannēs Tavushets'i (1180-after 1251) was a scholar and teacher of Kirakos Gandzakets'i, Vardan Arevelts'i and Grigor Aknerts'i, and the author of the History of the Tatars' Invasion, which was lost (Galstyan, 1962:118 [n. 127]).

${ }^{46}$ In the Autumn of 1236, Vanakan and Kirakos were taken to the fortress of Gag, where only Vanakan Vardapet was allowed by the Mongols to be bought by the local people for eighty dahekans (Kirakos Gandzakets'i, 1961:244-252). Dahekan is Persian for dahgān, the name of the silver coin corresponding to the Greek drakhme 
religion of the Mongols, as well as knowledge of Mongolian, which he elaborates in Chapter 32. ${ }^{47}$

Several points can be highlighted in this work with regard to the Mongols. The first relates to Mongol vocabulary. Kirakos spelled the Mongol words in the way they were pronounced at that time, which is itself one of the contributions of this Armenian author to Mongol studies. An important point that caught my attention is the way Kirakos interprets the words for 'sea' as naur-tangez, and 'river' as moran-ulansu. 'Sea' in Mongolian is dalai, 'lake' is naur, 'ocean' is tengez, and 'river' is mörön. Ulansu is an archaic expression for 'river' that is preserved in some dialects of Mongolian. However, for the Mongols in both the past and present whose country was and still is land-locked, the dual use of any water element is very common and it is remarkable that Kirakos' vocabulary shows this usage. The middle-Mongolian köke (qnquj) is given for 'heaven,' 'God' is given as tengri, and $e l\left(\zeta_{l}\right)$ and irgen ( $\left.k p l u w i\right)$ for 'earth.' Around 70 words and their meanings that Kirakos includes in his Mongol vocabulary still await linguistic analysis, which will certainly contribute to the study of middle-Mongolian.

The second point is that his work deals in depth with the history of his own age: The crushing of the Georgians by the Mongol armies in 1220/1221 and the sacking of the cities of Gandzak (Ganja), Shamkor (Shamk'or), Lori (Lorii), Ani, Karin (Erzurum) and of many other districts, including Khachen. ${ }^{48}$ Kirakos is very explicit about the extent of the destruction wrought by the Mongols in Greater Armenia and Georgia, and also shows great concern about the Armenian lords' actions under Mongol pressure. He observes the hopeless situation of Prince Awag in resisting the Mongols and his decision to submit to them. ${ }^{49}$ The author also comments on the breach of international etiquette in the handing over of Seljuk refugees to the Mongol commander Baiju by the Cilician Armenian King Het'um I (r. 1226-1269), which was justified on the grounds of the safety of his kingdom. ${ }^{50} \mathrm{He}$ records that Het um I followed the exam-

(Hübschmann, 1962:133; Bedrossian, 1985:132). It is 50 dahekans in Vardan Arevelts'i (1991:146). Kirakos escaped captivity. Vanakan Vardapet and Kirakos Gandzakets'i were in Mongol captivity for about one year (Kirakos Gandzakets'i, 1961:243-252; Davit' Baghishets'i in Hakobyan, 1956:346).

47 Kirakos Gandzakets'i, 1961:271-275.

48 Ibid., 235-237, 241-243, 254-255, 258-262, 267-269.

49 Ibid., 254-257, 262-267.

${ }^{50}$ Ibid., 285. 
ple of the Georgian king who went to the Mongol Khan to express his submission. The Armenian monarch sent his brother Smbat to the Mongol court and later he himself went to Mongolia. ${ }^{51}$ The author also recounts Het um's campaigns in Syria and describes the sacking of Baghdad by the Mongols. ${ }^{52}$

The third point is that Kirakos wrote his observations of early Mongol administrative-fiscal policies in Armenia and Georgia prior to the Mongol governor Arghun's census of 1243/1244. ${ }^{53}$ Furthermore, Kirakos notices the important fact that Hülegü (1256-1265), on coming to Armenia, was a royal prince but not yet a Khan and so refers to him as 'Khan-like' (quiquál) Hülegü. ${ }^{54}$ According to Kirakos, the Mongol army stationed in Armenia under the command of General Baiju feared Hülegü as if he were Khan. ${ }^{55}$ Unfortunately, his history abruptly breaks off for unknown reasons after describing the war between the Il-Khan Abaqa (1265-1282) and Berke Khan (12571267) of the Golden Horde in 1266.

The fourth point is that Kirakos mentions the Mongol-Armenian agreement, established between the Mongol Khan and the Cilician Armenian monarch, the reference to which follows in later chapters.

Finally, the work relies on oral reports of the informants and firsthand witnesses the historian met and interviewed, which reflect the plausibility of this source. Since his main account is of the Zak'arid princes' deeds and their relations with the Georgians and the Mongols, the work possibly was written for the Zak'arids.

Nonetheless, some discrepancies over the location of certain events are found in his history that contradict the accounts given by Muslim historians, which will be mentioned later. As is common in medieval historical records, Kirakos' history is not free from fanciful tales about the non-human shapes of barbarian peoples or their nonhuman behaviour.

Despite these, the Patmut'iwn Hayots' remains one of the most valuable thirteenth-century Armenian sources for the Mongols due to its abundant information about the dynamics of Mongol-Armenian relations.

\footnotetext{
51 Ibid., 314-317, 364-372.

52 Ibid., 377-384, 387-389.

${ }^{53}$ Ibid., 312-314.

${ }^{54}$ Ibid., 373.

55 Ibid., 375.
} 
Another significant source to complement Kirakos' writings is the work of Vardan Arevelts'i (ca.1200-1271), entitled the Hawak'umn Patmutean (Historical Compilation). ${ }^{56}$ Since Kirakos and Vardan were students of the same teacher, Vanakan Vardapet, and they wrote their histories at more or less the same time, the sources tend to reinforce each other. However, the key point is that this source is different in that Vardan introduces Armenian clerical attitudes towards the Mongol invasion of Greater Armenia, which stands alone among the Armenian sources. For this alone, it is important to look at his biography. From the comments he left about himself, we may conclude that Vardan Arevelts'i was born around 1200 in the region of Gandzak in north-eastern Armenia. ${ }^{57}$ It is also clear that Vardan taught in several monasteries and then went to Jerusalem. On his way back, he stopped in Cilicia and remained there for five years. ${ }^{58}$

According to Kirakos Gandzakets'i, in Cilicia, Catholicos Kostandin Bardzrberdts'i (1221-1267) was very concerned about the devastation of Greater Armenia under the Mongols, attributing these sufferings to their sins. Therefore, the Catholicos entrusted Vardan with an Encyclical Letter written for the ecclesiastics of Greater Armenia, which was comprised of 25 points of instruction for the religious canons..$^{59}$ In 1246, Vardan travelled through the districts of Greater Armenia collecting the signatures of the monks and lords and then sent this letter back to the Catholicos. ${ }^{60}$

Vardan stayed for a while in the district of Kayen, teaching. ${ }^{61} \mathrm{He}$ returned to Cilicia later and remained there until 1251 and then left for Greater Armenia again with a Letter of Spiritual Advice from the Catholicos Kostandin for the congregations to help in the theological disputes about the Son of God between Armenians and Roman Catholics. ${ }^{62}$ He spent the rest of his life in Greater Armenia.

Unlike Kirakos' writing, the Historical Compilation of Vardan falls into the category of chronicles, rather than of histories, in the early

${ }^{56} \mathrm{He}$ also wrote on geography and Commentaries on Grammar, the Psalms, and the Song of Songs; (Thomson in Vardan Arevelts'i, 1991:5-7).

${ }^{57}$ Ibid., 6.

${ }^{58}$ Ibid., 6.

${ }^{59}$ Kirakos Gandzakets'i, 1961:293-310.

${ }^{60}$ Ibid., 310-311.

${ }^{61}$ Ibid., 311.

${ }^{62}$ Vardan Arevelts'i, 1991:148; Kirakos Gandzakets'i, 1961:329-338; Thomson, in Vardan Arevelts'i, 1991:7. 
Armenian tradition and is based on a wide range of previous Armenian sources. ${ }^{63}$ Vardan reviews in a very condensed manner the general course of human history based on the narratives of Genesis and brings the history of Armenia up to 1267 . He engages with the Mongols only at the end of his chronicle. He dates the first arrival of the Mongols in the land of Greater Armenia to 1220 and describes the division of the Armenian land into lots by the Mongol commanders, as does Kirakos Gandzakets'i, albeit very briefly. ${ }^{64}$

More of his insights are also found in his narration of his visit in 1264 to Hülegü in Tabriz. He depicts the Mongol Il-Khan as having a very positive attitude towards the Christians. However, he was most impressed by Hülegü's Nestorian Christian wife Doquz (Toquz) Khatun, who is mentioned in his work with a degree of excitement. ${ }^{65}$ An important detail which is found in his source, along with those of Step'annos Orbelian and Kirakos Gandzakets'i, is the Il-Khan Abaqa's marriage to Maria Despina, the daughter of the Byzantine Emperor. ${ }^{66}$ At this point, the script of the Historical Compilation for some reason was lost and was found again by a relative of Vardan 18 months later in the bazaar of Tiflis. Vardan added only a few more pages, however, and ended his Chronicle in 1267 with the death of Catholicos Kostandin. ${ }^{67}$

This work is well addressed in terms of the author's opinion of the Armenian ecclesiastical position in relation to the Mongol invasion. Vardan's personal view of the first two Mongol Il-Khans, the Cilician King's visit to the Mongol court, ${ }^{68}$ and the attitude by which he dealt with the information available to him reflects the plausibility of this source.

Another important source which supports the main goal of this study is the work of Grigor Aknerts'i (1250-1335) or Akanets'i, entitled the History of the Nation of the Archers, or T'at'arats' Patmut'iwn (Patmut'iwn vasn Azgin Netoghats') in Armenian. His work has long been accessible in French, Russian and English translations. ${ }^{69}$

${ }^{63}$ Thomson, 1999:126; Thomson in Vardan Arevelts'i, 1991:5, 9.

${ }^{64}$ Vardan Arevelts'i, 1991:142-144.

${ }^{65}$ Ibid., 149-150, 157-161; for the details, see Chapter 6.

${ }^{66}$ Ibid., 161; Kirakos Gandzakets'i, 1961:399; Step'annos Orbelian, 1910:470. On Abaqa and Despina, see Chapter 7.

67 Thomson, in Vardan Arevelts'i, 1991:9.

${ }_{68}$ Vardan Arevelts'i, 1991:148-148.

${ }^{69}$ French translation by M. Brosset in 1851, Russian by Patkanov in 1871 and English by Robert P. Blake and Richard N. Frye in 1954. 
The authorship of this source is associated with three different names: Vardan Patmich', Maghak'ia Abegha and Grigor Abegha Aknerts'i. N. Pogharean, in his introduction to the critical edition of 1974, proved that the first two could not be the authors of the work, however. ${ }^{70}$

Grigor Aknerts'i in his History of the Nation of the Archers describes the events relating to the Armenians from the reign of Chinggis Khan down to $1271 / 1273 .{ }^{71}$ The work was written in 1273 in Akants' Anapat (the Hermitage of Akan) in Cilicia. ${ }^{72}$ Unlike traditional Armenian historiography, although the author introduces himself as a student of Vanakan Vardapet, along with Vardan and Kirakos, this source is far from being a universal history. Its main consideration is the history of the thirteenth-century Cilician and Greater Armenians. The analysis of this source, in terms of our main topic, concerns the following:

First, unlike the work of Kirakos Gandzakets'i, the History of the Nation of the Archers has some discrepancies in dating some events that occurred in Greater Armenia before the 1250s, such as stating the first appearance of the Mongols in Armenia in 1214 instead of 1220, and the defeat of the Sultan of Rūm in 1239 instead of 1243. The reason may well be that the author was not an eyewitness of these events. Of course, these might be scribal errors as well.

Second point is that, from the 1250s onwards, Grigor accurately provides some details on the Mongols, Mamluks and Armenians, on a history that was well known to him and was connected to Cilician Armenia, that make this source very important to this study, as well as to researchers of this particular period.

Thirdly, Grigor Aknerts'i contributes to Mongolian studies by mentioning many names of the Mongol chieftains who governed in Greater Armenia. ${ }^{73}$ Akinean, Alishan, Oskean and Blake suggest that

${ }^{70}$ Grigor Aknerts'i, 1974:5-15. Prior to Pogharean, Vardapet Nersēs Akinean and Fr. Hamazasp Oskean of the Vienna Mekhitarist Congregation raised the issue of excluding the name of Maghak'ia from the authorship of the work; Grigor of Akanc', 1954:271-274.

${ }^{71}$ Grigor Aknerts'i, 1974:28, 36.

72 Ibid., 54. According to Pogharean, the manuscripts are found in the Hakobeants' collection of the Armenian Patriarchate in Jerusalem, MS no. 32 (v. 1, Jerusalem, 1966:144-147); and MS no. 960, (v. 3, 1968:518, 527-528). Pogharean found the Armenian text edited with an English translation and notes by Robert P. Blake and Richard N. Frye with many misprints; Grigor Aknerts'i, 1974:5-15.

${ }^{73}$ Grigor Aknerts'i, 1974:26. 
Grigor had possibly used Vanakan Vardapet's lost annals as his source, which is possible. However, the series of Mongol names and expressions, which are not found in other works, show that Grigor added his own knowledge to his History of the Nation of the Archers. ${ }^{74}$

The fourth point is that the source has some colourful details of the Mongol-Armenian relations, like the reception of the Cilician Armenian King by the Mongol Khan, his readiness to fulfil all wishes of the King, ${ }^{75}$ and the Mongol-Armenian treaty established by Smbat Sparapet and the Mongol general Baiju. ${ }^{76}$

Another significant author is Step'annos Orbelian (1250/60-1304), the metropolitan of the province of Siwnik', who wrote the Patmut'iwn Nahangin Sisakan (History of the Siwnik' Province). ${ }^{77}$

The History of the Siwnik' Province has 73 chapters, starting with the creation of the world, recounting the time of Sisak, the predecessor of the Orbelian House, until the author's own days in 1299, when the History was completed.

From Chapter 66 onwards, information on the Mongols is found. Since Step'annos Orbelian personally interacted with the Mongols, his history is essential for information on the Orbelians and their relations with the Mongols that is not found in other works. His opinion of the Il-Khans is in line with the policy of the Orbelian House, which aimed to get power over other Armenian families through the Mongols. ${ }^{78}$ From his work it is clear that Step'annos himself paid a visit to Arghun Khan (r. 1284-1291), who honoured him. After the death of Arghun Khan, he had to visit Tabriz again, this time to meet the Il-Khan Geikhatu (r. 1291-1295), who re-estab-

74 Grigor of Akanc', 1954:6-8.

75 Grigor Aknerts'i, 1974:37-38.

76 Ibid., 31; see Chapter 2.

77 Relatively detailed information about his life is to be found in his work. In Chapters 65 and 71 of the History of the Siwnik'Province, he writes about himself as metropolitan and prelate. From childhood, he was brought up by the great prince Smbat Orbelian. Tarsaich Orbelian was the father of the historian. Step'annos Orbelian was ordained a priest in 1280 and in 1285 was sent to Hromklay, the Catholicosal See, to be anointed as a bishop. Before he arrived, however, news reached him at Sis that Catholicos Hakob Klayets'i (1268-1286) had died. Therefore, he spent three months in Adana, as a guest of King Lewon III (1269-1289) until the appointment of a new Catholicos. On 14 April 1286 (on Easter day), Step'annos was ordained by Catholicos Kostandin as a bishop, the metropolitan of Siwnik', and spiritual leader of Eastern Armenia. In the same year, he returned home (Step'annos Orbelian, 1910:477-482).

78 Step'annos Orbelian, 1910:410-420. 
lished the Orbelians' rights. In connection with the accession to the throne of Ghazan Khan (r. 1295-1304), Step'annos was in Tabriz for the third time when he was given more rights than under former rulers. ${ }^{79}$ The source can be viewed as a narration of the glorious deeds of the Orbelian House, although for the early part of his work, Step'annos Orbelian probably used the sources of his predecessors, namely Kirakos Gandzakets'i and Vardan Arevelts'i.

Apart from Step'annos Orbelian, there is another Step'annos called Episkopos, a chronicler of the thirteenth century, who wrote a Chronicle. ${ }^{80}$ He started his work from the events occurred in 1193, when the Chronicle of Samuel Anets'i ended. ${ }^{81}$ This source was mistakenly attributed to Step'annos Orbelian and, in 1942, Ashot Abrahamian published this Chronicle under the name of Step'annos Orbelian. ${ }^{82}$ Due to events described in common by Step'annos Episkopos and by Step'annos Orbelian in the Patmu'tiwn Nahangin Sisakan, it was claimed that this Chronicle was written by the latter. However, L. Khach ikian and V. Hakobyan expressed their doubts and argued that it was a different Chronicle, written by Step'annos Episkopos of Siwnik'. ${ }^{83}$

Step'annos Episkopos' Chronicle begins in 1193 with a short introduction and ends in 1290, thus covering almost 100 years; however, due to confusion around its authorship, this Chronicle was left out of the orbit of scholars' use. Without a doubt, it is one of the most important Armenian sources that relates events that occurred in Greater Armenia, Georgia and Cilicia, and involves the Zak'arids, the Mongols and the Mamluks, as well as the Il-Khans.

This study uses the Chronicle of Step'annos Episkopos and values it for its details that are not found in other sources relating to the historical events in the Caucasus, Cilician Armenia, and the Near and Middle East. The Chronicle has some colourful moments regarding the depiction of the conquest of Karin by the Mongols and his surprise about how quick and suddenly the country was found full of Tatars and how these Tatars considered the manuscripts and church utensils as their booty. These details are without doubt impor-

79 Ibid., 482-483.

80 The Chronicle is held in Matenadaran, MS no. 8481; Hakobyan, 1951:32; Galstyan, 1962:n.80, 33.

${ }^{81}$ Hakobyan, 1951:35-44.

82 Ibid., 33.

83 Ibid., 33-34. 
tant in order to understand the Armenians' reaction to the Mongol invasion. ${ }^{84}$ Therefore, the Chronicle of Step'annos Episkopos indisputably augments the list of Armenian historical records for the Mongol period.

The Annals, by an unknown author of the thirteenth century who lived in Sebastia (Sivas) and was thus named Sebastats'i, is another source that requires our attention because previous scholarship has paid insufficient attention to it. ${ }^{85}$ The importance of this source is enormous; it gives a full account of the Mongol conquest of Armenia and of its regional history. The Annals cover the period from the first century AD until 1220. Then, after an interruption because the pages describing the events of 1221-1254 were lost, ${ }^{86}$ the chronicle goes on until 1300 , which is corroborated better by other sources.

An important characteristic of the Annals of Sebastats'i is that the author describes historical events along with natural calamities that preceded or followed warfare or the devastation of Armenian lands. For example, he observes that the earth cracked and oozed black water before the Mongol commander Chormaghan penetrated the Caucasus, and notices the earthquake that occurred before the Mongol governor Arghun started the census in Erznka and Sebastia in 1254. The comet, which appeared in 1264, foretold the death of Hülegü Khan who died in 1265. After the death of King Lewon, a great earthquake killed many people and, when Ghazan Khan battled against the Mamluks, a severe famine followed in Sebastia in $1300 .{ }^{87}$

Some mysterious signs preceding the plunder of Gandzak described by Sebastats'i are very similar to what Kirakos Gandzakets'i mentions. ${ }^{88}$ These few similarities in the descriptions in these two texts may suggest that Sebastats 'i was well aware of Kirakos' writing; however, it does not indicate that these texts are related to each other.

\footnotetext{
${ }^{84}$ Step'annos Episkopos in Hakobyan, 1951:35-42; in Gastyan, 1962:35.

${ }^{85}$ Three manuscripts of Sebastats'i that held in Matenadaran were published by G. Manvelian and G. Abrahamyan in 1940 and later as the Minor Chronicles of the Thirteenth-Eighteenth Centuries in the second volume by Hakobyan in 1956; extracts of it were translated by Galstyan into Russian in 1962.

${ }^{86}$ According to both Hakobyan and Galstyan, the text of the oldest of the three manuscripts, attributed to Sebastats'i in the Erevan Matenadaran, (no. 2174) goes as far as the events of 1220 and was carried on by a continuator with some slips until 1309; the other two manuscripts each end in different years (1297 and 1300) (Hakobyan, 1956:115; Galstyan, 1962:106, n.1).

87 Hakobyan, 1956:139, 141, 148, 151.

${ }^{88}$ Kirakos Gandzakets'i, 1961:235-237. For the example of the poplar tree, see Chapter 2.
} 
The names of battlefield locations and the consequences of certain events given by Sebastats'i expand the information from other sources, and suggest that he had access to some alternative information, making it as important as those mentioned above.

Before introducing the next sources, it is important to see from the works described above that the Armenian historiography of the thirteenth century, especially those written in the 1270s, are rich and often very detailed in their information about the Mongol-Armenian relationship. The six major authors offered for consideration above deal in general with the issues of the Mongol invasion and the events that occurred in the Armenian territories and beyond them. These sources undoubtably reflect the growth of medieval Armenian historiography. In addition to that, they represent additional excellent examples of world medieval historiography.

The following sources represent the historical writings of the Cilician Armenians. The Chronicle of Smbat Sparapet (1208-1276), a brother of King Het'um I, is one of the major works on the Armenian Kingdom of Cilicia and a valuable source for the Crusades and the Mongol-Armenian affiliation, as well as for ArmenianByzantine, Armenian-Persian and Armenian-Arabic relations. ${ }^{89}$ The first section of the Chronicle, which covers the period from 951 to 1162, mainly follows the Chronology of Matthew of Edessa (d. ca. 1140) and of his continuator Gregory the Priest. Smbat's original work covers the period from 1163 to 1272 and for an unknown reason terminates there. An anonymous writer continues the Chronicle up to the year $1331 .{ }^{90}$

The Mongols are mentioned in the Chronicle of Smbat Sparapet in connection with the flight of the members of the Seljuk Sultan's family to Cilicia. He also gives detailed information on the penetration of the Mongols into Khwārazmia, Central Asia and the Middle East. The author is explicit about the capture of the city of Samarqand since he stayed there on his way to the Mongol court in Qara-Qorum and from Samarqand he wrote a letter to his brother-in-law, King

89 Galstyan, 1962:47-64.

${ }^{90}$ Der Nersessian, 1973:353. There are three Armenian editions of the Chronicle published in Moscow in 1856, Paris in 1859 and in Venice in 1956. Extracts from this work were translated into French by V. Langlois in 1862, by E. Dulaurier in 1869, and by G. Dédéyan in 1980, into English by Der Nersessian in 1973, and into Russian by A. Galstyan in 1962 and in 1974 (Thomson, 1995:198-199). Smbat Sparapet is also the author of a Lawcode and the translator of the Assises d'Antioche. 
Henry I of Cyprus or Henri de Lusignan (1218-1253). In his letter, Smbat mentioned many places he passed through and many Christians he saw scattered in the East. ${ }^{91}$

The interesting point of the Chronicle of Smbat Sparapet is that the author offers his own reasoning behind the historical events to many of which he was an eyewitness. Thus, he attributes the failure of the Mongols in Syria in 1260 to illness among Mongol troops and horses as a result of the hot climate. ${ }^{92}$ Since the source was written for the Het'umids, Smbat was well aware that this failure had a negative consequence for Mongol-Armenian military cooperation, as had been established by the Het'umids. Being delegated to attend Batu Khan and then to travel to Mongolia to open negotiations with the Mongol Khan, Smbat Sparapet has written a valuable work for consultation.

Another important Armenian source that merits consideration is La Flor des Estoires de la Terre d'Orient by Hayton..$^{93}$ The author is also known as Het'um Patmich' (d. ca. 1311) or Het'um the Historian. This is a major source for the medieval history of Mongolia, as well as the Middle East, and is as renowned as Marco Polo's or William Rubruck's travel books. ${ }^{94}$ By order of Pope Clement V (1305-1314), the Armenian monk Het'um (Hayton), Lord of Korikos, a member of the royal family, dictated this history in French in the city of Poitiers in 1307. In the same year, it was translated into Latin by Nicole Falcon (Nikoghayos Salkon), ${ }^{95}$ then in the last third of the fourteenth century into Spanish ${ }^{96}$ and later it was re-translated into French by Jean le Long in $1351 .{ }^{97}$ There are two Tudor English translations (probably made in the 1520s), ${ }^{98}$ as well as German, Italian and Dutch versions. The edition I used the most is the second edition of the translated version from Latin into Armenian by the Rev. H. Mkrtich`Awgerean. ${ }^{99}$

${ }^{91}$ Galstyan, 1962:64-66.

92 Der Nersessian, 1973:370; Halperin, 1985:48.

93 Hayton, 1869.

${ }_{94}$ On Marco Polo and his travels, see Jackson, 1998b:82-101 and edition by Komroff, 2003. On Rubruck, see Jackson, 1990, 1987a:92-97; Komroff, 1989.

${ }_{95}$ Hetoum, 1529.

${ }_{96}$ Hethum, 1934.

97 RHC, DA, 2, lvii; liii-lv.

${ }_{98}$ Het'um, 1988.

99 Het'um Patmich', 1951. 
This work is valued in terms of the historiography of the Western Crusades, the Armenian Christians and Papal diplomacy. ${ }^{100}$ But also it appeals to the Muslims and Mongols and is a remarkable account of the history, culture, ethnology and geography of the people who inhabited the Near and Middle East and Central Asia during the thirteenth and fourteenth centuries.

However, according to Bundy and Jackson, this work represents early fourteenth-century Armenian propaganda aimed at promoting the Latin-Mongol-Armenian relationship and reflects the engagement of the Armenian elite to justify their action to ally with the Mongols. ${ }^{101}$ Indeed the author was not a contemporary of the first submissions of the Armenians to the Mongol Khan and the final section of this source deals with a proposal for a Crusade to reconquer Palestine, especially the Holy Land, in cooperation with the Mongols and Armenians.

Putting aside this notion of appealing for a Crusade, I would rather propose to look at La Flor des Estoires de la Terre d'Orient as a source of Mongol-Armenian relations written by an Armenian historian, since this source is, according to Bundy, 'the most sophisticated example of medieval Armenian historiography.' ${ }^{102}$

La Flor des Estoires de la Terre d'Orient begins with an account of the 14 oriental kingdoms that existed in the thirteenth century, with details of their inhabitants, natural resources and political status. The part that relates to the Mongols begins with a description of the realm of Cathay or Northern China. ${ }^{103}$ Many details of the Mongols and their history, from this historian's viewpoint, are found in this work. For instance, Chinggis Khan in La Flor des Estoires de la Terre d'Orient is a poor old man who had a vision of a white man riding a white horse, and who addressed him as Chinggis. This white man told Chinggis that, by the providence of God, he would rule over the

${ }^{100}$ Bundy, 1987:223-235.

101 Ibid., 233; Jackson 2005a:120-121.

102 Bundy, 1987:233.

103 The term Cathay (Khitai) emerged after the fall of the T'ang dynasty (685-907), when the empire was divided into regions under the domain of the Tangquts, the Ch'i-tan, the Chin and the Sung (Shirendyb, 1966:95-103). After 947, the people called Khitan were sinicised and became a native Chinese dynasty, the Liao. In the twelfth century, the Qara-Khitai, a group of people who took refuge in Central Asia after the overthrowing of the Khitan/Liao Empire, entered eastern Iran but affected only Transoxania (Boyle, 1968:147-148). On Qara-Khitai, see Biran, 2005. 
Mongols. The enthroning ceremony of Chinggis, according to the nomads' tradition, was held on a black carpet. ${ }^{104}$ Lifting him up, the Mongols named him Chinggis Khan. The administrative and military systems of the Mongols were characterised in the History by the decimal system ${ }^{105}$ and by their obedience to the legislation, called Yasa. ${ }^{106}$ The story continues that God told Chinggis Khan to go west and conquer countries. Before setting out, the Mongols had to kneel down nine times and, as Het'um emphatically states, from this, the worship of the number nine started among the Mongols. After kneeling and worshipping, the sea receded to open the road to the west. ${ }^{107}$ The accounts of some of the Mongol customs in existence at that time, as well as the myths and legends of Mongolian origin, are given, as is consistent with reports by Marco Polo and other Western travellers. The issues of the faith, customs and behaviour of the Mongols are reported in depth:

Murder and prostitution were not considered a sin among the Mongols, but taking the bridle away from the horse's mouth is a mortal sin. It is not shameful to flee if it is worthy. It is difficult to chase them, as they are good archers from the rear. They know how to seize countries, but they do not know how to keep them. They do not allow others to lie, however they could lie freely. But in wartime, they keep their word. ${ }^{108}$

Despite the fact that the source was written for the special purpose of persuading the Latin powers to ally with the Mongols, as well as a few lapses on dates and details, the History of the Tatars still has value as a contemporary source for the Mongols for several reasons. First, it has a reconstruction of the history of Mongol-Armenian relations as far as it was available for the purpose of attracting the attention of Western kings.

${ }^{104}$ In the Mongolian tradition, it is a white felt blanket. However, Het'um explained the choice of black colour, saying that 'the Mongols never had fine cloth, or maybe they were so foolish and vile that they did not know how to get it' (Het'um Patmich', 1951:33).

${ }^{105}$ Any military unit was based on the decimal system, where the nuclear number increased in multiples of ten to tumen, or 10,000. Each commander was in charge of ten people. It was an easy way to be accountable and to take responsibility (Shirendyb, 1966:109).

${ }^{106}$ Yasa or Jasa is the derived version of the Mongolian Code of Law Ikh-Jasag. The yarliks or decrees issued by the Khan should never conflict with the Yasa (Shirendyb, 1966:129).

107 Het'um Patmich', 1951:39.

${ }^{108}$ Ibid., 74. 
Second, it is clear that the Mongols were seen by the Armenian author as the Christians' only allies against the Muslims in order to liberate the Holy Land and to save the Crusader states along the Syrian coast, thus resolving a long-standing battle against the Muslim world. This was also a common point of view of the lords in both Greater and Cilician Armenia.

Third, although the reference of Het'um Patmich' to the preparations made to convert Möngke Khan to Christianity does not seem to be historically accurate, this act is also mentioned by other Christian travellers. Therefore, this source cannot be dismissed as mere propaganda. As in the case of every medieval historian, we have to understand and take account of his outlook and aims in making use of the materials he records.

Fourth, one of the interesting points of this source lies in the fact that the text of a Mongol-Armenian agreement between the Cilician Armenians and the Mongols is included in detail. Although the details of this agreement are not found in other sources, the actual fact of his mentioning that the Armenians entered into an alliance with the Mongols is supported by other Armenian sources written long before Het'um Patmich', in particular that by Kirakos Gandzakets' $i .^{109}$ This may reflect a belief held true at the time. Therefore, it is impossible to exclude this source from our discussion if only because the Armenian interpretation of historical events is put forward.

Besides these major sources, there are many minor ones, such as the Chronicle of King Het'um II, written in 1296, which covers the period from the tenth century until his own ruling days. The work was continued by different people up to $1351 .{ }^{110}$ Due to this work, the issues of Mongol-Armenian cooperation under Mamluk pressure became possible to discuss. The Chronicle of Mkhit'ar Ayrivanets'i (1222-1291) goes up to 1289, though the dates are not specified. At the end of his Chronicle, there is some information about the Mongols, starting from the first raids of Jebe and Sübedei into Greater Armenia until the enthronement of the Il-Khan Arghun (1284) and the death of the Cilician King Lewon III (1289). Mkhit'ar has some details that are not found in other Armenian annals, such as Hülegü

\footnotetext{
109 For more details, see Chapter 2.

110 Extracts of the Chronicle are translated in Hakobyan, 1951:65-101; in Galstyan, 1962:71-78.
} 
killing all the Chaghataids (qupuiur; who were the Chinggisid princes) and Tegüder fleeing to Swanetia to escape execution. ${ }^{111}$

Some other Armenian authors are also worth noting. Frik (d. ca. 1300), the Armenian poet of the thirteenth century, is the author of many Poems, written in colloquial Armenian, and was originally from Siwnik' but wandered and died in Cilicia. His reference to the conditions of the Armenians under the Mongols and his sympathy towards the Il-Khan Arghun makes this source worth studying. Nersēs Palients', the chronicler of the fourteenth century, reports the historical events relevant to the Mongol-Mamluk-Armenian relationship and to the Armenian Catholicosate in Hromklay.

The Armenian colophons are important sources for this study, ${ }^{112}$ not only because of their detailed information about the year and place the manuscripts were made, along with the copyist's and recipient's names, but also due to their references to the dates of the Mongol destructions or census-taking; this includes, for example, the colophon of the Gospel of the monastery in Getik dated in the early 1230s. ${ }^{113}$

More particularly, I found them useful for their explicit references to the Mongol Il-Khans (e.g., the colophon of the Armenian Gospel from Vaspurakan dated 1304), ${ }^{114}$ and the political and economic conditions under which the manuscripts were copied, as well as their descriptions of the circumstances of a particular event that was characteristic of a certain village, town or monastery (the colophon written in Glajor monastery in 1314). ${ }^{115}$ They were also helpful in establishing the family relationships of some of those who were mentioned as patrons or recipients. ${ }^{116}$

In general, although the Armenian colophons of the thirteenth century describe the Mongol invasion as a human disaster, they express more neutral views about the Mongols, whereas the Armenian

\footnotetext{
${ }^{111}$ Mkhitar Ayrivanets'i, 1860:68.

112 The colophons are collected and published by Khach'ikyan in 1950 in the Colophons of the Armenian Manuscripts of the Fourteenth Century, by Mat'evosyan in 1984 in the Colophons of the Armenian Manuscripts of the Thirteenth Century, and selectively translated into English by Sanjian in 1969 in the Colophons of Armenian Manuscripts, 1301-1480.

${ }^{113}$ Mat'evosyan, 1984:183.

114 Sanjian, 1969:48.

115 Ibid., 58.

116 Even in the thirteenth century, historians like Step'annos Orbelian made great use of the colophons in their works (Bedrosian, 1997:52).
} 
manuscript colophons of the early fourteenth century interpret the Mongols as God's chastisement for human sins.

In spite of there being no direct link to the subject of MongolArmenian relations, the large collection of inscriptions of western and eastern Armenia represents another important source for this study. These inscriptions explore the details of taxes and tributes levied in Greater Armenia in the thirteenth and fourteenth centuries (e.g., the inscription of the city of Ani, dated 1270 or the edict of Abū Sa īd [r. 1316-1335] in Ani), as well as the deeds of certain people inhabiting a certain area, and the memorials they left behind (e.g., the inscriptions in Gandzasar, dated 1280 and 1286). ${ }^{117}$

\section{Muslim Sources}

This study uses a range of Muslim sources mainly with regard to the Mongols, although there are also some references to Greater Armenia and more to Cilician Armenia. If the majority of Armenian sources for the Mongols fall into the category of chronicles with a chain of events related to their dates, the Muslim sources, especially the Persian ones, are more like histories dedicated to a specific people, area or theme. Even the titles of the works speak for themselves. The major work remains the Jämi al-Tawarikh (Compendium of Chronicles) written in $704-710 \mathrm{H}$. (1305-1310/1311) by Rashīd al-Din (ca. 645-718 H./ 1247-1318), a general history of the world from the earliest time to 1310-1311 with special accounts devoted to the Mongols. ${ }^{118}$ This is the first systematic and comprehensive history of the known world and is unique in its research methods. ${ }^{119}$ When Rashīd al-Dīn was commissioned to compose the history of the Mongols by the order of the Il-Khan Ghazan (1295-1304), he clearly needed some sources and informants for consultation and advice. The collaboration of Rashid al-Dīn, the Il-Khan's vizier and Bolad Chinksank or Pūlād Chīnksānk, the Great Khan Qubilai's representative in Iran, on state business is well known. ${ }^{120}$ However, less well known is his role in the writing of Jämic al-Tawarikh. A thorough examination of the facts described in this famous work suggests

117 The Annals of the Inscriptions by K. Kostaneants' and the eight volumes of Corpus Inscriptionum Armenicarum published in Erevan from 1960-1999 remain the foremost collections of Armenian inscriptions.

118 For the complete reference to this source, see Melville, 2008a:462-468.

119 Jahn, 1967:79-87; Boyle, 1971:19-26; Morgan, 1982b:119-121.

120 Allsen, 2001:72-80. 
that Bolad was much more than an informant and it is likely that the Compendium of Chronicles was a joint venture with Rashīd al-Dīn. ${ }^{121}$

Scholars believe that Rashìd al-Dīn is most likely to have used the Secret History and the lost Altan Debter (Golden Book), the compendium of ritual texts for the Chinggisids mentioned above, copies of which were at the Mongol courts in Iran and China. ${ }^{122}$ According to Babayan, the Armenian scholar, among his many sources Rashīd al-Din also used the works of the Armenian authors of Kirakos Gandzakets 'i, Vardan Arevelts i, Step'annos Orbelian and Het'um Patmich'. Babayan made this suggestion after making a comparative study of some extracts of the above-mentioned authors' works. ${ }^{123}$ Indeed, Rashìd al-Dīn's description of famine in the city of Martyropolis (Mayyāfāriqīn), while Hülegü's army besieged the city, follows Kirakos Gandzakets i without any alterations. ${ }^{124}$ However, Babayan's claim to see parallels between Step'annos Orbelian and Rashīd al-Dīn's accounts of affairs between Arghun Khan and Bugha are debatable. ${ }^{125}$ First of all, the extract he compares is attributed to Step'annos Episkopos, not to Step annos Orbelian. ${ }^{126}$ Although the text is more or less the same and the order of narration is similar, it is not identical. Rashīd al-Din has more details of the events and names. ${ }^{127}$ Nonetheless, the similarities in the narration of Tegüder's (Negüder) rebellion against Abaqa Khan and its aftermath in Grigor Aknerts $i$ and in Rashid al-Dīn are striking. ${ }^{128}$ Therefore, the assumption that Rashīd al-Dīn used the works of the Armenian historians is more than convincing, especially for the narration of historical events that took place in the Caucasus and nearby regions.

The final version of Jämi al-Tawarikh included a history of the Mongol and Turkic tribes, the history of Chinggis Khan, his ancestors and successors, a history of Biblical prophets, and the emergence of Islam, the Caliphates and the major sultanates, with an extensive description of genealogy and geography along with the accounts of

${ }^{121}$ Bira, 2001:397; Allsen, 2001:79, 85-88, 96-97.

${ }_{122}$ The Altan Debter and the Secret History of the Mongols were two independent works, by no means identical (Morgan, 1990:12).

123 Babayan, 1965:81-94.

${ }_{124}$ Ibid., 91; Kirakos Gandzakets í, 1961:385-386; Rashīd al-Dīn, 1946:55.

125 Babayan, 1965:92.

126 Step annos Episkopos in Hakobyan, 1951:48-49; Step'annos Episkopos in Galstyan, 1962:41-42.

127 Rashīd al-Dīn, 1946:119-122.

${ }^{128}$ Grigor Aknets'i, 1974:63-65; Rashīd al-Dīn, 1946:72. 
the Chinese, Jews, Turks, Indians and Franks. Unlike the mainstream of non-Armenian sources, the Jämi al-Tawarikh refers to the Armenians separately from the Georgians but as part of a larger canvas of Mongol subjects, which is very valuable.

Before Rashīd al-Dīn, there were Persian authors who wrote about the Mongols. The most famous of them is Juvayni $(623-681 \mathrm{H}$. I 1225-1283) who wrote the Ta'rikh-i Jahān-Gushā (History of the World Conqueror) in the 1260s. ${ }^{129}$ Juvaynï's family was employed by the Mongols. His father was Amir Arghun's deputy over a large area, including Georgia and Armenia, and his brother was a Minister of Finance under the Il-Khans, Hülegü and Abaqa. Juvaynī himself travelled twice to Mongolia. The information he gathered on the Mongols, Qara-Khitais, Uighurs and Khwārazmians gave him a chance to commence his history of the career and life of Chinggis Khan, followed by warfare, law and customs. The Mongol invasion of Islamic lands, the Ismā îlīs and other historical events are included in his history. Juvayni is not explicit about the Armenians. The facts that reflect Greater Armenia in his history are hidden under a general reference to Georgia, even when he talks about the Khwārazm-Shah Jalāl al-Dīn and his activities, destruction and executions in Armenia.

Another source, the Tabaqāat-i- Nāșirī (Nasiri Tables) was written in 1259-1260 by Jūzjānī (589-664 H. / 1193-d. after 1265), contemporary with the Mongol conquest. ${ }^{130}$ This is a history of the Ghurids in Afghanistan, written in India, outside the Mongol sphere of influence. The 23rd and last section (Tabaqa) contains information about the Mongol invasion. ${ }^{131}$ The source is mainly consulted for the first stage of the Mongol invasion of Greater Armenia. Jüzjānī considers the Mongol disaster as God's judgement on the sins of the Muslims; however, he sees in the fall of the Ismāi îlis the triumph of orthodox Muslims. ${ }^{132}$ Although there is no direct connection between this source and the Armenian sources, the notion of seeing the reason for the Mongol conquest as a punishment for sin is relevant. The Armenian view of this point will be introduced in due course in this study.

129 For full reference to Juvaynī's work, see Melville, 2008b:378-382.

${ }^{130}$ Jūzjānī, Juvaynī and Rashīd al-Dīn are discussed in detail in Morgan, 1982b:109-124.

${ }^{131}$ Jūzjānī, 1970:869-1296.

132 Ibid., 935, 1187-1211. 
Apart from these major sources for the latter period of the Il-Khanate's administration, this study also consulted Vașșāf. ${ }^{133}$ For the geography of Gurjistan Vilayet and the administration of taxes by the Il-Khanate, use was made of the Nuzhat al-Qulüb (Pleasure of the Hearts) (ca. 740 H. / 1340) and the Ta'rīkh-i Guzìda (Selected History) $(730$ H. / 1330) by Ḥamd Allāh Mustawfī Qazvīnī (ca. 680-744 H. / ca. 1281-1344). ${ }^{134}$ These Persian sources are constructive in giving a broader picture of Mongol administration in Iran, which allow me to examine some details concerning Greater Armenia.

The principal Arabic sources related to this study refer mostly to the Cilician Armenians and their relations with the Mongols and Mamluks, such as the Kitāb al-Mukhtașar (Compendious Book) by Abu'l-Fidā' (d. 1332) ${ }^{135}$ or the Dhail ta'rìkh Dimashq (Continuation of the Chronicle of Damascus) by Ibn al-Qalānisī (1070-1160), ${ }^{136}$ along with al-Maqrīzī, Ibn Shaddād and many others. The al-Kāmil fi'l-ta'rìkh (Complete History) by Ibn al-Athïr (1160-1233) is useful to compare the first appearance of the Mongols in Greater Armenia with the situation in Islamic countries. ${ }^{137}$ Nasawi is consulted in connection with Jalāl al-Dīn Khwārazm-Shāh. ${ }^{138}$ The Arabic sources assisted my work by providing more details on Mongol-Armenian joint actions in Syria. In contrast to the Armenian sources where anti-Muslim notions are not very prominent, the anti-infidel approach in Arabic sources is quite conspicuous. Regardless of their didactic tone, the Arabic sources are full of direct information relating to the Mongols and their ventures in Syria, which confirms in general what is mentioned in the Armenian sources of the relevant period.

133 Vașșaf was a Persian official (panegyrist) who continued Juvaynīs History from 1257 to 1328 (Saunders, 1971:257). Vașșaf's style is extremely convoluted compared with the clarity and simplicity of Rashīd al-Dīn (Morgan, 1988:166, 1990:21). On Vașșaf's literary achievements and on the critical edition of Tajziyat al-amșar, see Pfeiffer, 2007:107-129.

${ }_{134}$ On Mustawfī and his works, see Melville, 2003b:631-634.

135 The French translation of Kitāb al-Mukhtașar is included in RHC/Or., 1872:1-115, 181.

136 Gibb, 1932.

137 The extracts are translated into French in RHC, Or.1, 1872:187-744.

138 Nasawī, 1996. 


\section{Other Sources}

To supplement the major sources, I have used other works of contemporary Western travellers, such as Marco Polo, Carpini and Rubruck, as well as some Chinese sources, the Yüan Shih and the Liao Shih in translation or as quoted. The second volume of The Georgian Sources for Armenia and the Armenians, including K'art'lis Chovreba (History of K'art'li), compiled and translated into Armenian by L. Melikset-bek in 1936, added to my understanding of the Georgian side of events because a substantial proportion of the important officials at the Georgian court were Armenian. ${ }^{139}$ This study found the Melikset-bek's edition useful in considering the actual relationship between the Georgian kings and their vassals, the Greater Armenian lords.

Syriac sources available in English translation are used in this study with regard to Mongol-Christian and Muslim-Christian relationships. The French translation of the History of Mar Yaballaha III by anonymous author and the two volumes of The Chronography of Gregory Abū al-Faraj by Bar Hebraeus (translated by Wallis Budge in 1932) undeniably assist in comparing Syriac and Armenian Christian sources.

139 Bedrosian has a detailed introduction to the Anonymous Chronicle included in the History of K'art'li (Bedrosian, 1979:8-10). 


\section{A BRIEF HISTORICAL BACKGROUND OF THE ARMENIANS AND MONGOLS}

Before moving on to the relationship set up between the Mongols and the Armenians, it is necessary to give a short historical background about the origin, location and history of them. It is especially important to mention the historical conditions of the Armenians on the eve of the Mongol conquest, when Greater Armenia and Cilician Armenia existed separately from each other with no major political contacts, although with constant cultural, religious and trading links. The Mongols were dealing with two different vassal states, of which the Greater Armenians were their subjects, while the Cilician Armenians were their allies.

\section{The Armenians in Greater Armenia}

The history of the Armenian people goes back to Hittite and Assyrian times and it has formed a part of the history of the north-eastern region of the Mediterranean world, existing and being influenced by Aegean-Anatolian, Mesopotamian, Iranian, Hellenistic and RomanoByzantine civilisations. ${ }^{1}$ A description of earlier Armenian geography is given by Strabo (63/64 BC-24 AD), the Greek geographer and historian. ${ }^{2}$ The historical Armenian plateau is the highest among the three land-locked plateaus that form the northern part of the Middle East. In the west, it borders with the Anatolian plateau, and in the south-east with the Iranian plateau. ${ }^{3}$ Mount Ararat (Masis) is about 17,000 feet (about 5,200m) above sea level and represents the highest point not only in Armenia, but also in West Asia. The southern frontiers of Armenia reach the lowland steppes of Syria and Mesopotamia; to the north, they extend to the trench plains of South Caucasia (Georgia and Azerbaijan) backed by the great wall of the

\footnotetext{
1 Toumanoff, 1966:593; Redgate, 2000:2-6, 18-24.

2 Strabo, XI, xiv, 1969:317-341. On the geography of Armenia according to Strabo, see Syme, 1995:27-83.

3 The subsequent description of Armenia follows Hewsen, 1997:1-17.
} 
Caucasus mountain range which stretches between the Caspian and Black Seas. Hewsen notes that the natural frontiers of the Armenian plateau are clearly defined in the east, the north-west and the south, while the borders in the west, the south-east and the north are obscure. ${ }^{4}$ This point enables us to make an assumption that the people inhabiting those frontier areas would have had reasons not only to mingle with each other, but also to fight for possession and control of these lands.

Scholars' views differ on the origin of the Armenian people. Some agree that the Armenians were not the original inhabitants of the plateau. ${ }^{5}$ The predominant view is related to the migration of people, particularly the Indo-European Hittites, to Transcaucasia and Asia Minor at the beginning of the second millennium BC. According to some historical and archaeological studies, they migrated into the Armenian plateau, forming a federation of people known as the Armens. This version of the Armenians' origin is suggested by Russell, who through linguistic research into the other inhabitants of the Armenian plateau, such as the Phrygians, Persians, Babylonians, etc., proposes that the people who moved from far south-eastern Europe into Anatolia became the Armenians. ${ }^{6}$ However, according to another hypothesis, which suggests no mass migration, it is considered that the proto-Armenians were the native inhabitants of this territory situated on the highlands of the Anatolian plateau between the Black and the Caspian Seas. This recent account of the Armenians' origin, though having its supporters, has not gained wide approval. ${ }^{7}$ However, the common outcome of both hypotheses is that by the development of bronze in the Middle East, the Armenian people ended up inhabiting the region around the Biblical Mount Ararat. ${ }^{8}$

From the middle of the second millennium $\mathrm{BC}$ to the thirteenth century $\mathrm{AD}$, the Armenian plateau lay at the crossroads of rival

${ }^{4}$ Hewsen, 1997:2.

${ }^{5}$ Ibid., 2.

${ }^{6}$ Russell, 1997:19-24.

7 Ibid., 24.

${ }^{8}$ Mount Ararat, towering over the great river valleys of Araxes (Armenia), Lake Van (in present day Turkey) and Lake Urumiah (in present day Iran) has the status of a holy site to the Armenians. One of the six major Armenian rivers, the Araxes, watering the vast Ararat plain and passing through many of the great cities of Armenian antiquity, has played a considerable part in the national life of the Armenians. It is the only true river of modern Armenia and it has become, like Mount Ararat, a national symbol to the Armenian people. 
empires: Assyrian, Median, Achaemenid, Parthian, Sasanian, Arab, Seljuk and Mongol to the south and east, and Seleucid, Roman, Byzantine and Crusader to the west.

The migration of Turks to Asia Minor that occurred between the eleventh and fifteenth centuries also directly involved a change in the policy, demography and economy of the Armenian people who populated vast areas across that region. From $c a .1016$ onwards, most of the Armenian highlands underwent several invasions of various Turkic speaking people from different regimes. ${ }^{9}$

The growing Georgian military power in the late eleventh century established temporary supremacy in eastern Asia Minor. Georgia was transformed into a powerful pan-Caucasian empire. ${ }^{10}$ (see Map 1). During the reign of David the Builder (1089-1125), the Armenian territories of Lori, Agarak, the Kiurikian holdings, eastern Gugark, western Utik, Gag, Kavazin, Kayan, Terunakan, Norberd, Tavush and many others were freed of nomadic Turkomans by the Georgian army from 1110-1123. ${ }^{11}$ Ani was taken in $1123 .{ }^{12}$ Several noble Armenian families, joining the Georgian army, participated in the liberation of their country from the Turks. ${ }^{13}$ During the reigns of Demetrē I (1125-1155) and Georgi III (1156-1184), the Georgian conquest continued, when the Armenian lords of the Zak arian (Mkhrgrtseli), Orbelian (Orbeli), and Artsruni (Mankaberdeli) were brought within the ruling structure of the country. When the Georgian Bagratids achieved their apogee under Queen Tamar (1184-1213), the Armenian Zak'arid brothers Zak'arē and Iwanē were appointed as the commanders of the Armeno-Georgian armies. ${ }^{14}$

In the first decades of the thirteenth century, north-eastern Armenia was under the rule of the Zak'arid family. The land was received by the Zak arids as the reward from the Georgian crown for their military service. ${ }^{15}$ Although the Zak arids paid tributes to the Georgian court, Armenian economic and cultural life reached new heights. ${ }^{16}$ The lands of Lorí, Ani, Aragatsotn, Bagrewand, Tsaghkotn, Kogovit, Surmari and other north-western territories were under the

\footnotetext{
9 Cahen, 1968:27, 32-50.

10 Toumanoff, 1966:623.

11 Babayan, 1976:525.

12 Bedrosian, 1997:251.

13 Ibid., 88.

14 Step'annos Orbelian, 1910:391-392; Kirakos Gandzakets'i, 1961:162-163.

15 Babayan, 1976:541-542.

16 Bedrosian, 1997:253, 255.
} 
jurisdiction of the amirspasalar (commander-in-chief) Zak'arē and his son Shahnshah. Subject to the Zak'arid House were the families of the Vachutians, Pahlavunis, Mamikoneans, Artsrunids and others. ${ }^{17}$

The eastern areas Bjni, Geghark'unik', Vayots'-Dzor, most of Artsakh, Siwnik', Nakhichevan, Dwin and Erevan were under the jurisdiction of the atabeg (atabek) Iwanē Zak'arian and his son Awag. First Dwin and later Bjni were centres of this division. The subjects of Iwanē's family were the Orbelians, Khaghbakians, Dopians, HasanJalalians and others (see Map 4). ${ }^{18}$ The representatives of these major Armenian families entered into direct contact with the Mongols in order to retain their conquered lands, the discussion of which follows in next chapters.

\section{The Armenians in Cilician Armenia}

In the history of the Armenian people, the Cilician period is defined principally through the actions of two Armenian families, the Rubenids and the Het umids; ${ }^{19}$ by the political union with Byzantium and the Catholic Church; and by the involvement in the Frankish Crusades.

Geographically, the area was surrounded by three mountain ranges: the Taurus Mountains, the Anti-Taurus Mountains and the Amanus Mountains (see Map 2). ${ }^{20}$ Topographically, it consisted of two distinctive regions: The one, Cilicia Pedias, a fertile plain bounded by the Taurus and Anti-Taurus Mountains and the Mediterranean Sea, and the other, Cilicia Tracheia, a stony, rugged region that stretched to the west. The Taurus Mountains, reaching heights of about 11,500 feet $(3,500 \mathrm{~m})$ separated Cilicia from Cappadocia and were a natural means of defending the land from the north and the west. In particular, the mountains protected the land from neighbouring countries, and the main entry from the Taurus Mountains was by the Cilician Gates, a long and narrow pass leading to the city of Tarsus. Through this Gate, Alexander the Great, as well as the

\footnotetext{
17 Babayan, 1976:543.

18 Step'annos Orbelian, 1910:397; Babayan, 1976:546-550.

19 On the Pahlawunis (ca. 1071-ca. 1149), see Dédéyan, 1996:169-173.

20 The geographical description of the terrain follows Mikaelean, 1952:5-14.
} 
Crusaders, entered Asia Minor. ${ }^{21}$ Abū al-Fidā', an Arabic geographer, writing in the fourteenth century, comments that the kingdom of Little [Cilician] Armenia is called the Bilād Sìs, the northern frontier of which stretches from Balis besides the Euphrates to Tarsus and the Mediterranean Sea. ${ }^{22}$ Access to the Mediterranean Sea in the south was the potential advantage of this location.

In medieval European historiography, this land was called Ermenie, Armenia or Lesser Armenia, causing some confusion in the naming of different states of Armenia. ${ }^{23}$ In order to differentiate Cilicia of the eleventh to fourteenth centuries from Lesser Armenia, which existed from the first century BC to the south and south-west of Pontus, modern historians refer to Cilicia as the Armenian Kingdom of Cilicia. In this work, Cilician Armenia stands for the territory of the Armenian Principality (1080-1199) and the Armenian Kingdom of Cilicia (1199-1375; see Map 2). Contemporary Armenian historians referred to Cilicia (Kilikia) also as Ashkharh Kilikioy (Cilician Land), or Ashkharh Kiliketswots (Land of the Cilicians) ${ }^{24}$ or Koghmank'Kiliketswots (Country of Cilicians). ${ }^{25}$

Over the centuries, Greeks, Arabs and Jews populated the region. The Byzantine Emperor Justinian II (685-695), due to the threat from the rapid spread of Islam and as a measure of defence against it, started to implement a policy of relocation of the native population and their mass transfer deeper into the empire. ${ }^{26}$

Among the earliest Armenian settlers in Lambron (Cilicia) was Oshin from the House of Het'um, as well as Baron Gogh Vasil (Basil the Robber) and many other noblemen. ${ }^{27}$ When the Seljuk Sultan

21 Mikaelean, 1952:11.

22 Abu-l Fidā, quoted in Le Strange, 1890:27.

$23 \mathrm{RHC} / \mathrm{DA}, 1869$. The term Lesser Armenia has denoted either Armenia Minor since the third century BC or the provinces of Armenia west of Euphrates, which, after the administrative reorganisations of the Roman Emperor Justinian I (527-565), were named as Armenia I and Armenia II (see Hewsen, 2001, 1997:1-17.

24 Smbat Sparapet, 1869:610, 667.

25 Kirakos Gandzakets'i, 1961:27, 354.

26 Byzantine policy encouraged the emigration of the Armenians from their main lands to the western part of the Euphrates. This flow continued during the Arab invasion (from the seventh to the ninth centuries) as well as the Seljukid incursion (eleventh century), when the repressive taxes levied by new governors caused massive Armenian immigration into Cilicia (Der Nersessian, 1962:631).

27 The Armenian lieutenant Gogh Vasil inherited Raban and Kesun upon the death of Philaretus in 1092. He also held Hromklay for a time (Der Nersessian, 1962:632). 
Alp Arslan defeated the Byzantine emperor in the battle of Manzikert in 1071, the Armenians, especially the chieftains, came to hold the strategic fortresses and, consequently, positions of dominance in Cilicia. ${ }^{28}$ In other words, an Armenian Principality emerged in this territory, which was under the control of the two main Armenian families already mentioned, the Rubenids and the Het'umids. The conflict between two princely families over each others' territories troubled the Catholicos Gregory III (1113-1166), who, after his failure to reunite them, sought refuge in Hromklay (Qal'at ar-Rūm) where later, in 1151, the See of the Cilician Armenian Catholicos was transferred. ${ }^{29}$

On the eve of the Mongol conquest, the prosperous and powerful reign of Lewon II (1187-1219), known as King Leon (Leo I) the Magnificent (r. 1199-1219) ${ }^{30}$ promoted the economic development of Cilicia through several trade routes: Syria-Konya-Constantinople; Tabriz-Marash-the Mediterranean; and the Persian Gulf-SyriaCilicia, which converged towards the Cilician ports of Ayas (Lajazzo), Korikos and Tarsus. ${ }^{31}$

His reign was continued by the joint rule of his daughter Zabel (Isabel) and Het'um I (1226-1269), the son of Kostandin of Lambron, finally bringing the two contending Rubenid and Het'umid families into an alliance. ${ }^{32}$ The period of Het'um's rule marked a golden age in Cilician Armenia. He strengthened the Armenians' ties with the Frankish states, especially with the Kingdom of Cyprus and the Principality of Antioch through family marriages. ${ }^{33}$ Nevertheless, peace was relative. Het'um faced problems on his eastern frontiers. The Mongol expedition approached Asia Minor.

${ }^{28}$ Bournoutian, 1997:276.

${ }^{29}$ Hromklay was offered to Gregory by Beatrice, the wife of Joscelin II, Count of Edessa / Courtenay (d. 1159), who was imprisoned by the Turks. Later, Gregory purchased it from his son, Joscelin III (1159- 1200) for 15,000 dahekans (Der Nersessian, 1973(I):338.

${ }^{30}$ Der Nersessian, 1973(I):340.

31 Toumanoff, 1966:633.

32 Zabel, Queen of Armenia (1219-1252), Lewon's daughter from his second marriage to Sybille Lusignan of Cyprus.

33 Burger, 1988:xvi. 


\section{The Mongols}

According to archaeological discoveries, the vast steppes of the Mongolian plateau have been populated since 800,000 BC. ${ }^{34}$ The Mongol, Turkic and Tungusic pastoral tribes made this plateau their homeland, which lay between the northern edge of the Tien Shan and the southern end of the Altai Mountain range. The Mongolian plateau is divided into taiga forest in the north, steppes and river valleys, which stretch from west to east, and the desert area in the south. The excessive heat of the Gobi desert in summer and the bitter wind from Siberia in winter made the Mongol tribes settle and master the steppes or the grassy plains that were located between the mountain ranges, where the Onon, Orkhon, Tuul and Kherulen rivers flowed. The development of herding in Mongolia dates from 2000 $\mathrm{BC}$, long before the construction of the Great Wall in China (ca. 209 $\mathrm{BC})$ that was used to protect the Chinese border from the nomadic peoples that swept across the region..$^{35}$

From ancient times, various peoples have inhabited the territory of modern Mongolia, before or besides the Mongols proper. The earliest kingdoms were the Xiongnu (Hsiung-nu /Hun /Hunnu) (209 BC-93 AD), ${ }^{36}$ the Xianbis (Hsien-pi) (the first to the third centuries), ${ }^{37}$ the Jujan or Juan-Juan Empire (the fourth and fifth centuries) and the Turkic Khanate (the sixth to the seventh centuries) with its centre in the Orkhon valley. ${ }^{38}$ In 745 , the Turkic Khanate was replaced by the Uighurs. The capital of the Uighur Khanate was Qara-Balgasun or Ordu Baliq on the right bank of the Orkhon River. Uighur Khan Peilo (d. 756) and his heir Moyun-Chur (746-759) sat on the throne in 747 and succeeded in expanding his territories from the Altai Mountains in the west to the Khingans in the east, from the Gobi in

34 Tseveendorj, 2003:57-66.

35 Barfield, 1989:20-24, 28-30.

36 On Huns, see Maenchen-Helfen, 1973; Thompson, 1996. Much later, when the northern branch of Huns broke into four groups, the very last remnants of Huns travelled to the far west and became known to Europeans. Their notorious leader Attila (AD 406-453) caused terror in Europe and created an ephemeral state in Central Europe, which collapsed after his death (Shirendyb, 1966:82).

37 While Xianbis absorbed some Huns, the southern Huns moved to China and Central Asia (Shirendyb, 1966:82). More on steppe pastoralism and the interactions of steppe empires with neighbouring Chinese dynasties in late BC and early AD in Barfield, 1989:20-24, 32-45, 85-101, 120-127.

38 Shirendyb, 1966:88. On early steppe Empires and their relations with China, see Barfield, 1989:20-97, 120-127. 
the south to the Sayan Mountains in the north. ${ }^{39}$ The economy of the Uighurs was based on animal husbandry, hunting as well as agriculture, since some of them practised a sedentary lifestyle. Those who were settled were also engaged in the construction of buildings. ${ }^{40}$ The outstanding achievement of both the Uighurs and the Mongols was the adoption of a script based on the Sogdian alphabet, which was derived from Aramaic. ${ }^{41}$ Although the Uighurs were Buddhists, through the transmission of Sogdian culture, Manichaeism was declared the state religion in 763 . At the end of the tenth century, Nestorian Christianity entered Uighuria. Nevertheless, the majority of the Uighurs practised Shamanism. ${ }^{42}$ In 840, the Yenisei Kyrgyz tribes took the Uighur capital and expelled the native population. Some of the Uighurs fled to Western Turkestan and Dzungaria, some were absorbed by the Kyrkyzs, while others fled to Manchuria. ${ }^{43}$

The empires of Kyrgyzs (in the ninth century) and Kidans (Khitans, during the tenth and eleventh centuries) were the masters of the steppe until their role passed to many other Turkic and Mongol pastoral tribes of the Mongolian plateau of the twelfth century. Among these tribes the Naimans, Keraits, Merkits and Tatars were the most powerful. Mention must be made of the Oirats, Taiji'uts, Onggirats, Jalayirs, Onguts, Besuts and many others who were amalgamated into the Yeke Monggol Ulus (the Great Mongol State) in 1206. The man who led this nation to victory was Temüjin (Temuchin) of the Borjigin obogh (clan, tribe), better known by the title Chinggis Khan (r. 1206-1227). ${ }^{44}$ The representatives of these tribes made a great impact on the history of the Mongols and the Mongol Empire and for that reason, where it is possible, I give the tribes' names along with the names of the Mongols stated in this work.

39 Shirendyb, 1966:92-93.

40 Ibid., 94; Morgan, 1990:44-48.

${ }^{41}$ Before the invention of the Uighur script, the Uighurs used the Orkhon script (Shirendyb, 1966:95).

${ }_{42}$ Okladnikov, 1983:116.

${ }^{43}$ Shirendyb, 1966:93.

${ }^{44}$ Temüjin means the smith and the most popular explanation for his title as Chinggis Khan is that it stands for the Oceanic Khan or Universal Ruler. Another explanation for this name is that it derives from the Mongolian word 'chinga' (strong, solid, powerful) to mean unbeatable and firm (cf. Tsevel, 1966:823; Lessing, 1973:189). The etymology and meaning of Chinggis is still a subject of dispute. For the various explanations of Chinggis, see De Rachewiltz, 1989:281-298. 
With the assistance of his relatives and friends, Chinggis Khan was able to build up a disciplined army that expanded a steppe confederation into a world empire. The great achievement of Chinggis Khan in uniting the Mongol steppe tribes under one rule was dictated by his instinctive sense of survival, in terms of both politics and economics. For the most part, the union was the result of the emerging need to develop a nomadic infrastructure throughout the Inner Asian plateau. In addition, there was a power vacuum in most lands conquered by the Mongols. China was disunited and relatively weak due to the internecine strife between the Chin (Jin) and Sung dynasties. ${ }^{45}$ Central Asia was fragmented into several khanates and citystates. In the Middle East, the 'Abbasid dynasty that had ruled from Baghdad for five centuries was in decline. Russia was also disunited and fragmented. All of these areas suffered from a lack of centralised control, which was exploited by the Mongols.

The Yeke Monggol Ulus was the largest contiguous land empire at its apogee in the mid-thirteenth century (see Map 3). After Chinggis Khan's death in 1227, the conquered territories were ruled by his sons, by his senior wife Börte and by his grandsons. These territories later became autonomous separate Mongol Uluses (States). The Ulus of Jochi (1237-1357), later known as the Golden Horde (Altan Ordyn Ulus) or Qipchak Khanate (1243-1502) was the inheritance of Chinggis Khan's eldest son Jochi and grandson Batu. It included at its peak most of European Russia from the Urals to the Carpathian Mountains, with its southern borders on the Black Sea and its key base in the Pontic and Caspian steppe and its capital at Sarai. ${ }^{46}$ The Chaghatai Ulus or Chaghatai Khanate (1224-1678) formed the inherited territories of the second son of Chinggis Khan, Chaghatai, who controlled Transoxiana or most of what is now Central Asia. The Il-Khanate (1256-1353) that included Iran, Iraq, Afghanistan, Asia Minor and the Caucasus was ruled by the offspring of Tolui Khan, the youngest son of Chinggis. The Toluid Qubilai (Kublai) Khan (1260-1294) declared Mongol rule in China in 1271, which became known as the Yüan Empire or the Yüan Dynasty that lasted until

${ }^{45}$ Morgan, 1990:50-51.

46 In the Quriltai (Great Assembly) of 1235, it was decided to launch an expedition to Russia and Eastern Europe. In 1236, Batu started his conquest of Russia. The Golden Horde ruled over Russia from 1243 to 1480. 
1368 and expanded into Korea, Japan, Myanmar (Burma), Vietnam and Java (Indonesia). ${ }^{47}$

According to Morgan, 'the major difference between the Mongols and previous conquerors is that no other nomadic empire had succeeded in holding both the Inner Asian steppe and the neighbouring sedentary lands simultaneously. ${ }^{3} 8$ It is always challenging to understand how the Mongols were able to establish the largest land empire in world history with a population of about two million, ${ }^{49}$ when China alone had a population of a hundred million. ${ }^{50}$

The Mongols' intention to create a world empire was driven by their successful campaigns for expansion. ${ }^{51}$ Ratchnevsky, analysing Chinggis Khan's actions, indicates that there were prevailing political and military reasons. ${ }^{52}$ Scholars agree that each of Chinggis Khan's decrees to launch expeditions was based on specific circumstances, such as the assault on his diplomatic missions, trade disputes or the breakdown of agreements. ${ }^{53}$ Nevertheless, Chinggis Khan was vengeful, taking revenge on the Taiji'uts, the Tatars and the Tangquts. ${ }^{54}$ Verbal insults against the Mongols by Gürbesü, the Queen of the Naimans, were avenged. ${ }^{55}$ However, Chinggis Khan and his descendants launched attacks only after giving full warning of their intention. ${ }^{56}$ Mongol war techniques and tactics were surely connected to military organisation, and scholars agree that during sieges, the Mongols mastered the art of raiding independently several surrounding cities and places so that the rumours of terror would shock the entire population; this was true of Mongol tactics in Greater Armenia

${ }^{47}$ Qubilai's election in May 1260 was contested by his brother Arïgh Böke, who was proclaimed the Great Khan in June 1260 (Rossabi, 1988:53, 136).

${ }^{48}$ Morgan, 1986:5.

49 Saishiyal, 1987(I):564-565. During the time of Chinggis Khan, the population of the eastern steppe, modern Mongolia, was somewhere between 700,000 and 1,000,000 (Allsen, 2001:5).

${ }^{50}$ The population of China in the Sung and Chin periods was over 100 million (Langlois, 1981:20). No steppe power had ever fought against Chinese dynasties so persistently, like the Mongols (Barfield, 1989:198).

${ }^{51}$ Ratchnevsky, 1991:160.

52 Ibid., 121.

53 Allsen, 2001:17; Ratchnevsky, 1991:170;

${ }_{54}$ MNT, 2004:37(\$148-149), 39(\$153-154), 84(\$249).

${ }_{55}$ Ibid., 54(\$189).

${ }^{56}$ Ratchnevsky, 1991:129-130. 
as well. Chinggis Khan used terror as a strategic weapon. Purposeful terror with fewer losses was as useful as siege-craft. ${ }^{57}$

Chinggis Khan, who, according to Fletcher, after reaching a certain level of power, deviated from the 'supratribal' ruler, ${ }^{58}$ established the institution of loyalty through three important ties: anda, the tie of sworn brotherhood; khuda (quda), the tie of marriage; and nöker, the tie of friendship. ${ }^{59}$ This institution proved itself and worked as a basic concept to recruit people when he needed reliable support. Organising a military decimal system, where the units were divided into tens, hundreds and thousands, increasing up to ten thousands (tümens), Chinggis Khan broke the patriarchal tribal clan (obog) network, intermixing the tribes under 95 elite commanders. ${ }^{60}$ These commanders were appointed from different social strata: tribal chiefs, humble herdsmen and even vassal members. The most faithful followers and nökers (friends) formed the kheshig (kesig), ${ }^{61}$ the imperial guard, recruited from across tribal boundaries, which became a 'nursery of the new Empire's ruling class.'62

When Chinggis Khan set up the administration of his Empire, it bordered with the Chin Empire to the southeast, the Tangqut kingdom of Hsi-Hsia to the south-west and the kingdom of Qara-Khitai (Liao) to the west. ${ }^{63}$ These neighbours sought to destroy this newlyemerged kingdom, while it was still weak, so Chinggis decided to launch a pre-emptive strike. The weakest of them was the kingdom of Hsi-Hsia, and it was the first to experience Mongol attacks. The invasion of the Chin Empire followed. Learning that Western Liao planned to attack him, Chinggis Khan turned his attention to QaraKhitai in $1218 .^{64}$

This expansion brought the Mongols into direct contact with the territory of the Khwārazm-Shāh, Qara-Khitai's western neighbour. Embassies were exchanged between the two rulers. In the same year,

57 Ratchnevsky, 1991:160; Hildinger, 1997:128.

58 Fletcher, 1986:20.

59 MNT, 2004:17(\$92-93), 21(\$105), 26(\$118), 45-46(\$170-171), 78-79(\$238), 66(\$203).

60 Ibid., $74-75(\$ 220-225)$.

61 Ibid., 55(\$191), 75(\$226). On Kheshig in Iran, see Melville, 2006a:135-163.

62 Morgan, 1986:90.

63 The Chin Empire was located in northern China, with its capital at Peking (Beijing); the Kingdom of Tangqut lay in the upper reaches of the Yellow River, ruled by a people of Tibetan origin.

64 MNT, 2004:85-86(\$250-253). 
1218, a great caravan of Muslim merchants with about 500 camels loaded with gold, silver, Chinese silk, sables and other goods was sent to Khwārazm-Shāh by Chinggis Khan. Accompanying them were several Mongols sent on a special mission to the Khwārazm-Shāh's court. The local governor of Utrār, the border city in Kh"ārazmian territory, massacred the travellers, which was the direct cause of the Mongols' advance into Central Asia and further into the Middle East. ${ }^{65}$ The Mongols penetrated Transoxiana, Afghanistan and Khurasan. The Mongol generals Sübedei and Jebe then pursued the $\mathrm{Kh}^{\text {warazm}-S h a ̄ h ~ w e s t w a r d s, ~ b r i n g i n g ~ t h e ~ M o n g o l s ~ t o ~ A r m e n i a ~ i n ~}$ 1220.

${ }^{65}$ Barthold, 1977:397-398. 


\section{CHAPTER TWO}

\section{MONGOL NOYANS IN GREATER ARMENIA (1220-1245)}

The Mongols entered the Caucasus only at the beginning of the thirteenth century after their occupation of territories in Central Asia and defeat of the $\mathrm{Kh}^{\mathrm{w}}$ arazmia. ${ }^{1}$ By that time, the Mongols were hardly known to the region including the Armenians; Armenia was not on the Mongols' list of priorities either. The political circumstances of Armenia on the eve of the Mongol conquest embodied different powers in different regions. Thus, the Seljuks (Saljuqs) of Rūm had been in power in the western part since the end of the twelfth century; ${ }^{2}$ the Georgian Bagratid dynasty ruled the northern and eastern parts since 1089; and the political domination of the Ayyubids was still functional in some parts of the south since 1208. Only some of the southern territories were under the control of the Armenian ishkhans (princes). ${ }^{3}$ Of these, the Tornikids/Mamikonians ruled in Sasun and the Artsrunids in the districts of Mokk' and Rshtunik' in Vaspurakan. ${ }^{4}$

\section{The First Mongols in the Lands of the Armenians}

Greater Armenia stayed under Mongol lordship for more than one hundred years, from 1220 to $1344 .{ }^{5}$ In his doctoral thesis on the

${ }^{1}$ After the massacre of the merchants and of the Mongol Embassy, Chinggis Khan sent his envoys to the Khwārazm-Shāh protesting at his deceitful action and demanding the surrender of Innālchik, the governor of Utrār, but his envoys were killed by order of the Shāh, according to Nasawī, or were freed after their beards had been shaved, according to Ibn al-Athīr (Barthold, 1977:399).

2 The first Seljuk Turks arrived in Caucasia probably in the late 1020s (Peacock, 2005:211).

${ }^{3}$ For details, see the Introduction and Map 1. Cf. Hewsen, 2001:107-109.

${ }^{4}$ Ter-Ghewondyan, 1955:85-96. Contemporary Armenian sources refer to the lords as the ishkhans, the princes. To my knowledge in the sources, which were at my disposal, there is no single reference claiming them as nakharars. There is disagreement among scholars about the duration of the nakharar system both as a concept and as terminology; however, it is highly unlikely that the nakharar system, which existed in Armenia from antiquity, lasted until the Mongol invasion (Adonts, 1970:183; Garsoïan in Hovannisian, 1997:150). Therefore, I use the term ishkhans for princes and lords.

${ }^{5}$ Manandian, 1952:244. 
Turco-Mongol invasions of Armenia, R. Bedrosian analyses the Mongol conquest of Armenia within a chain of co-related TurcoMongol incursions into Armenia that occurred at the beginning of the thirteenth century, after the Seljuks, although he states that these invasions were hardly coordinated. ${ }^{6}$ Overall, he identifies them as invasion-migration. ${ }^{7}$ Disagreeing with this view, which is more relevant to the Seljuks, I have tried to analyse the actual size of the Mongol army that invaded Armenia. It is difficult to assess the number of Mongols who came to Greater Armenia or their physical presence during the conquest. Without doubt, it fluctuated within the limits of the nomadic army that included households, women and children. ${ }^{8}$ It is also debatable as to whether these armies aimed to settle in Armenia or to move forward following the conquest. Therefore, this study examines the Mongol conquest of Greater Armenia as a separate matter, excluding its connection with the conquests of Armenia by the Khwārazmians, by the Seljuks or by some Turkomans later in the abovementioned period, but considering it instead as an essential part of the Mongol conquest of the world. ${ }^{9}$

The Mongol occupation of Armenia proceeded in several wellcoordinated phases: scouting expeditions; initial allotment of Armenian land under Mongol lordship; and the final invasion. According to Armenian sources, the first Mongols emerged in Armenia in 1220 (669 Arm.). ${ }^{10}$ The years given in Grigor Aknerts $i$ as 1214 (663 Arm. $)^{11}$ and in Mkhit'ar Ayrivanets'i as $1211^{12}$ are not supported by any other sources and need to be considered as scribal errors as they both describe the battle of Georgio-Armenian troops against the Mongols near the river Kotman, which took place in the

6 Bedrosian, 1979:94.

7 Ibid., 64.

8 Kirakos Gandzakets'i, 1961:203. For the actual size of the Mongol armies, see Turnbull, 1980:22-24. The whole Mongol population did not participate in actual conquest, but only the army (Hildinger, 1997:11).

9 The invasion of the Caucasus by the Qipchak Turks in 1222 was not part of the Mongol conquests. Defeated by the Mongols, they withdrew to the Caucasus. The Khwārazm-Shāh Jalāl al-Dīn penetrated Armenian lands several times from 1225 to ca. 1230, fleeing from the Mongols. However, it was rather a consequence than a part of the Mongol conquests.

10 Step'annos Episkopos, 1951:38; Kirakos Gandzakets‘i, 1961:201; Vardan Arevelts'i, 1991:142.

11 Grigor Aknerts'i, 1974:22.

12 Mkhit'ar Ayrivanets'i, 1860:65. 
winter of $1220-1221 .{ }^{13}$ The most corroborated dates for this event are recorded by Vardan Arevelts'i (ca. 1200-1271) and by the anonymous author from Sebastia in his Chronicle. The latter states that, in the year 669 Arm. (1220), 20,000 Tatars under Commander Sübedei came to the land of Gugark from Albania (Aghvank'). ${ }^{14}$ The account given in Kirakos Gandzakets' $i$ that the Mongols came to Albania through the Derbent (Darband) Gates, is contradicted by the Muslim sources of Ibn al-Athīr (1160-1233), al-Kämil fi'l-ta'rīkh, and Rashīd al-Dīn (ca. 645/1247-718/1318), Jāmi al-Tawarìkh. According to them, the Mongols more correctly came to Armenia from the direction of Tabriz through the Mughan (Mūghān) Steppe. ${ }^{15}$

The occupation of the lands of the Armenians was not a main concern of the Mongols. If one follows the general scheme, it is obvious that the decision to launch a Mongol expedition was made at the quriltai (assembly) or by the order of Chinggis Khan. From the sources, it is understood that, in the year of the Hare (1219), in pursuit of 'Alā' al-Dīn Muḥammad Khwārazm-Shāh (r. 1200-1220), Chinggis Khan sent General Jebe as a vanguard, Sübedei as Jebe's rearguard and Toghachar (Toghuchar) as Sübedei's rearguard. ${ }^{16}$ It is worth noting here the triple figure of commanders. Triplication was one of important numbers in Mongol custom, especially in a military context, and it meant coordination and a prudent approach. ${ }^{17}$ Three persons were designed to act as one, hence 30 or 300 or even 30,000 persons, according to the decimal system of the nomadic army. The Secret History of the Mongols has several sets of triples, like this set of Jebe- Sübedei-Toghachar, or Chormaghan- Ogotor- Mönqetü, who will be mentioned later.

${ }^{13}$ Kotman (Touz) is a river near the fortress of Terunakan (Manandian, 1952:183-184). The name of the place of battle is recorded differently in the Armenian sources; it is the river Kotman in Vardan Arevelts'i, the river Kroman in Step'annos Episkopos and the plain of Kotman opposite the castle of Terunakan in Grigor Aknerts'i.

${ }^{14}$ Sebastats'i in Hakobyan, 1956:137. Aghvank' in the Armenian sources refers to Caucasian Albania (Barkhutareants', 1902:9).

${ }_{15}$ Ibn al-Athīr, 1940:140; Rashīd al-Dīn, 1952(Vol. 1, part 2):227.

${ }_{16}$ MNT, 2004:90(\$257); Rashīd al-Dīn, 1952(Vol. 1, part 2):209. On Jebe and Sübedei, see below, p. 54. Toghachar in Muslim sources is identified as Toghachar Küregen, a son-in-law of Chinggis Khan (Juvaynī/Boyle, 1997:174; Nasawī, 1996:91). Toghachar was from the noble Qongirat tribe, the male repressentatives of which used to marry the girls of Chinggis Khan's family (Rashīd al-Dīn, 1952[Vol. 1, part $1]: 162)$.

${ }^{17}$ For the symbolic meanings of the number three, see Dulam, 1999:45-78. 
According to Rashīd al-Dīn's narration of the Jāmi al-Tawarìkh, Chinggis Khan ordered the generals to return through Dasht-i Qipchak (Qipchak) and to join him in Mongolia only after the capture of Sultan Muhammad. ${ }^{18}$ In fact, as a result of the Mongol siege, the $\mathrm{Kh}^{\mathrm{w}}$ ărazmian Empire fell, causing its rulers to flee. Since Muhammad Khwārazm-Shāh had fled to a lonely island in the Caspian Sea and died there in 1220 and his son Jalāl al-Dīn (12201231) had fled to India in $1221,{ }^{19}$ the Mongols, after passing through Hamadan, withdrew to the Mughan plain. ${ }^{20}$

It is interesting to speculate why the main attention of these generals, who were sweeping across Iran, was suddenly focused on another direction, towards Armenia and Georgia. Probably the severe winter of 1220-1221 made Jebe and Sübedei choose the Mughan plain as a winter camping ground, which was found to be suitable for launching reconnoitring expeditions westwards, in which Armenia was discovered by the Mongols for the very first time.

Therefore, it is important to note that the abovementioned expedition of the Mongols to Khwārazmian territory signified not only the incursion of the Mongols into Western Asia, but also their emergence in the Caucasus. Through the Caucasus, they launched campaigns against the Qipchaks, Bulgars, Mordvins and the Bashkirs in 1229-1237. Then they devastated Rus' [Russia] in 1238-1240 and entered the territories of Eastern Europe in 1240-1242. ${ }^{21}$

In earlier literature relating to the Mongol conquest, the Mongols were frequently represented as a monolithic barbarous force under the name Tatars (Tartars). Actual study of the Mongol invasion of Armenia reveals that, under the general name 'the Mongols' or 'the Tatars,' there existed a range of individuals or groups of people representing different tribes at different times and thus different powers pursuing different goals.

Armenian sources record the names of the first Mongols to appear in Armenia as the generals Jebe and Sübedei. ${ }^{22}$ Jebe, also known as Jirgudai, was from the Besüt tribe. ${ }^{23} \mathrm{He}$ was the one who resisted

18 Rashīd al-Dīn, 1952(Vol. 1, part 2):209.

19 For Jalāl al-Dīn's conquest of Panjāb and Sind, see Jackson, 1990b:45-54.

${ }^{20}$ According to an Arabic source, there was a cold winter and snow in Hamadān (Ibn al-Athīr, 1940:137).

${ }_{21}$ Buell, 1992:19; Jackson, 2005a:40.

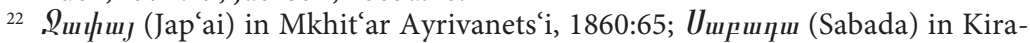
kos Gandzakets'i, 1961:240.

${ }^{23}$ It is the Yisüt tribe in Rashīd al-Dīn, 2002:151. 
Temüjin $^{24}$ in the fight in Khuiten (Köyitan) in 1202, shooting an arrow from a mountain top and wounding Chinggis Khan. However, in the Secret History, it is noted that Jebe wounded the so-called 'yellow war-horse with the white mouth' supposedly belonging to Chinggis Khan. ${ }^{25}$ When Jirgudai later came to submit to the Khan and confessed that it was he who had shot the arrow from the mountain top, Chinggis Khan valued his courage, accepted him as a man worthy of being his companion and called him Jebe or 'arrowhead.' ${ }^{26}$ In the quriltai of 1206 on the bank of the river Onon when Chinggis Khan was proclaimed the Great Khan of all the Mongols, Jebe was granted the title of Miangatyn Noyan or Commander of a Thousand. ${ }^{27}$ Ninety-five commanders were appointed that day. Among them was Sübedei, known as Sübedei-Baghatur, who was from the Urianqat tribe. $^{28}$

After Toghachar was dismissed for disobeying orders, ${ }^{29}$ Jebe with one tuman (tümen/tümān; ten thousand) soldiers and Sübedei with

${ }^{24}$ Temüjin was already honoured with the title Chinggis in 1189, after reaching agreement with Altan, Quchar and Sacha-beki, the chiefs of the Mongol tribes (MNT, 2004:28[\$123]; SHM, 2001:100).

${ }^{25}$ MNT, 2004:36(\$147); SHM, 2001:121. The reference to the 'yellow war-horse' in MNT is more allegorical than representative, for according to Mongol custom, it was taboo to address the Khan directly and here the white-mouthed horse is a symbolic representation of the Khan (MNT, 2004:35[\$145]; SHM, 2001:118). It is supposed that because of this taboo, Rashīd al-Dīn later suggests in his version that Jebe wounded the white horse, which was ridden by Burji Noyan, not by Chinggis Khan himself (Rashīd al-Dīn 1952[Vol. 1, part 1]:194).

${ }^{26}$ MNT, 2004:36, 90(\$145, 257); SHM, 2001:118, 250. For types of arrowhead, see MNT [military terms], 2004:246. In 1204, Jebe successfully fought Küchlüg, a Naiman refugee prince. In 1211, 1214 and 1231, he led the Mongol army against China (MNT, 2004:266-267).

${ }^{27}$ Jebe was a commander of the 48th thousand out of abovementioned 95 thousands. In 1211 and 1214, Jebe was sent to investigate China (MNT, 2004:266).

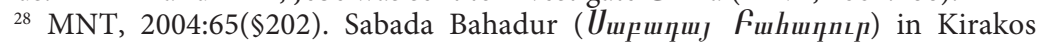
Gandzakets'i, 1961:204. Sübedei was a commander of the 52nd thousand (MNT, 2004:267). He was a brother of Jelme, a commander of the 9th thousand (MNT, 2004:254); Jelme was a close friend of Temüjin [Chinggis Khan], who saved Temüjin's life three times, including during the incident in Khuiten (MNT, 2004:35(\$145); SHM, 2001:98).

${ }^{29}$ Toghachar disobeyed the order of Chinggis Khan to act peacefully as the rearguard of Jebe and Sübedei in their reconnoitring expedition in 1219 and infringed on the territories of Amīn Malik (Amīn al-Mulk, a cousin of a Qangli Turk, malik of Herāt; Boyle, 1968:318; Nasawī, 1996:215-216). Due to this, Chinggis Khan wished to have Toghachar executed but forgave him and demoted him from his command (MNT, 2004:90(\$257); SHM, 2001:250). According to Rashīd al-Dīn, Togachar was killed in battle by the highlanders of Ghūr soon after (Rashīd al-Dīn, 1952(Vol. 1, 
another tuman marched towards Arran/Arrān. On their way, they met the Georgian and Armenian army and defeated them. Armenian and Muslim sources do not name the location of this first Mongol battle with the Caucasians. According to Rashīd al-Dīn and Ibn al-Athīr, the Mongols defeated a Georgian army of 10,000 men (half the size of the Mongol army) on a short reconnoitering expedition and returned to Tabriz. ${ }^{30}$ According to Kirakos Gandzakets'i, many well-organised soldiers suddenly passed from Caucasian Albania to Armenia putting to the sword 'men and beasts.' They came up to the city of Tiflis and then they went to the borders of the city of Shamkor. ${ }^{31}$ The Muslim sources do not give the exact date of this military incident. Armenian sources say that this battle took place in December 1220 and January 1221. ${ }^{32}$ According to Kirakos Gandzakets'i, after this battle, Jebe and Sübedei dwelt in a very safe place, known by the Mongols as Beghamej, which was between the cities of Partaw (Barda'a) and Bailakan (Bailaqān) in Arran. ${ }^{33}$ This they used as a base from which to launch attacks.

According to the Muslim sources, Jebe and Sübedei then besieged Maragha, Hamadan, Nakhichevan, Ardabil, Sarab and Bailakan in August-September 1221. Then Jebe and Sübedei attacked the city of Ganja (Gandzak), from where they went again to Georgia and crushed the Georgians. ${ }^{34}$ Consulting the contemporary Armenian sources, it becomes clear that the second and big battle occurred on the plain of Khunan, according to Kirakos Gandzakets'i, and on the banks of the Kotman river, according to Vardan Arevelts'i and Step'annos Episkopos. ${ }^{35}$ Manandian's study shows that both the Khunan valley and the river Kotman can be found along the banks of the river Kur. ${ }^{36}$

part 2):220. As Nasawī and Juvaynī state, he was killed in battle by an arrow near Nīshāpūr in November 1220 (Nasawī, 1996:93; Juvaynī/Boyle, 1997:175).

30 Ibn al-Athīr, 1940:137; Rashīd al-Dīn, 1952(Vol. 1, part 2):227.

${ }^{31}$ Kirakos Gandzakets'i, 1961:201.

32 Step'annos Episkopos, 1951:38; Kirakos Gandzakets'i, 1961:201; Vardan Arevelts'i, 1991:142.

${ }^{33}$ Kirakos Gandzakets'i, 1961:202-203.

${ }^{34}$ Ibn al-Athīr, 1940:137-142; Rashīd al-Dīn, 1952(Vol. 1, part 2):227-229.

${ }^{35}$ Step'annos Episkopos, 1951:38; Kirakos Gandzakets'i, 1961:201; Vardan Arevelts'i, 1991:142.

${ }^{36}$ Manandian, 1952:183. According to Hakobyan, Kotman is the right tributary of the river Kur (Hakobyan, 1951:55). Galstyan states that it is the modern river Touz, which passes through the fortress Terunakan (Galstyan, 1962:114[n. 81]). 
Thinking that the Mongols would stay in Arran until the Spring, the Georgians began gathering an army, asking for help from the governors of Azerbaijan (Āzarbāijān) and Khlat (Akhlāt) ${ }^{* *},{ }^{37}$ but Jebe and Sübedei did start their expedition to Georgia. They also had some Turkish and Kurdish reinforcements. ${ }^{38}$ In the plain of Khunan, the army of Lasha (r. 1213-1223), the Georgian king and Iwane Zak'arian, the atabeg, met two tumans of the Mongol army. ${ }^{39}$ With 5,000 men, Jebe set up an ambush while Sübedei went forward with the rest of the army. When the battle started, the Mongols used their old expedient of feigned retreat and the Georgians chased them up to the river Kotman until Jebe's sudden advance from the ambush ended the battle. ${ }^{40}$ The king and Iwanē fled, leaving Prince Vahram Gagets'i to fight on the right flank. ${ }^{41}$ Having pursued the rest of the Georgian army, the Mongols withdrew soon after.

It is worth mentioning here that Jebe and Sübedei carried a cross among their front line. This ruse is referred to in Western scholarship in relation to King David's army and Prester John. ${ }^{42}$ The Georgian queen, Rusudan, and the atabeg, Iwanē Zak'arian, must have been confused to see a cross in the hands of the invaders. According to Kirakos Gandzakets i, false information had preceded the Mongols that they were Christians who carried a portable tent-church and a miracle-working cross and had come to avenge their fellow-Christians from the tyranny of the Muslims. ${ }^{43}$ The Armenians were not ready to face the Mongols. A complaint about the Mongol invasion was addressed to Pope Honorius III (1216-1227) by Iwanē and later it was left to the queen to explain the reason why no precautions

37 Ibn al-Athīr, 1940:137.

38 Ibid., 138.

39 According to some sources, it was a Georgian army of 60,000 men (Step'annos Episkopos, 1951:39; Grigor Aknerts'i, 1974:21).

${ }^{40}$ Kirakos Gandzakets'i, 1961:203; Rashīd al-Dīn, 1952(Vol. 1, part 2):228.

41 Vardan Arevelts'i, 1991:142.

42 In 1141, when the Seljuk Sultan Sanjar was defeated by a Qara Khitan Emperor, it was believed that a Christian king called John, who was also an ordained priest, existed in Central Asia. The Latin world wanted to believe in this legend and, from the 1160s, circulated within Catholic Europe a Letter of Prester John, a forgery, which was copied and translated into several languages during the next two or three centuries (Jackson, 2005a:20-21). In 1221, when the Crusaders were in Egypt, another legend spoke of the Mongols as the army of a mysterious David, the Christian King in India, who was on his way to aid the Crusaders (Morgan, 1990:178). On various articles about Prester John, see Spuler, 1960:29; Beckingham and Hamilton, 1996; Morgan, 1996:159-167; Rachewiltz, 1971:30-40; Jackson, 1999a:711).

${ }^{43}$ Kirakos Gandzakets`i, 1961:202. 
were taken. ${ }^{44}$ It is not clear whether the 'cross' idea was executed deliberately as a consequence of good intelligence gathering, with the intention of misleading the Armenians and Georgians, or whether the Mongol front-line was composed of representatives of Nestorian Christian tribes. However, as Jackson states, this strategy remained one of the tactics of Mongol diplomacy and warfare. ${ }^{45}$

In 1222, when the Mongols returned to Armenia and Georgia, their scouts found that the Georgians and Armenians were ready to fight, so they decided not to wage war and went 'somewhere else. ${ }^{46}$ In fact, the troops of Jebe and Sübedei went to the Gates of Derbent. ${ }^{47}$ On their way to Derbent, they besieged the city of Shamakha in Shirvan. After many days of brave defence by the inhabitants, the city fell to the Mongols. ${ }^{48}$ In 1223, after defeating the Russian troops on the river Kalka, Jebe and Sübedei departed to the east to join Chinggis Khan. ${ }^{49}$ Their scouting expedition through Azerbaijan, Armenia, Georgia and the Northern Caucasus to Russia was completed. The army of Jebe and Sübedei did not stay in Armenia any longer. ${ }^{50}$

\section{The Advance of Chormaghan on Greater Armenia (1222-1242)}

After the withdrawal of the Mongols from the Caucasus, the political condition of the region was very tense. In 1222, the Qipchaks, pursued by the Mongols, crossed into Georgia, Shirvan and Arran. The

${ }^{44}$ Mutafian, 1999:149; Jackson, 2005a:49. Reality showed that the Mongols were not saviours of the Christians at all. This disappointment for the Armenians gave rise to the idea that the Lord in his anger had roused the Mongols in order to rebuke them (Grigor Aknerts'i, 1974:20).

45 Ibid., 49.

46 Vardan Arevelts'i, 1991:142.

47 Kirakos Gandzakets'i, 1961:203.

${ }^{48}$ Ibn al-Athīr, 1940:141.

49 The withdrawal from the Caucasus probably had to be sanctioned by Chinggis Khan and approved by the quriltai (great assembly) of January/February 1221 which was held near the river Benaket (Syr Darya) when Chinggis Khan decided to go back to Mongolia (Rashīd al-Dīn, 1952[Vol. 1, part 2]:226).

50 Afterwards, Sübedei headed the expedition to North China in 1233 (Munkuev, 1965:66). He marched on Carpathia towards Hungary and Poland in 1241 (Liddell Hart, 1927:22). Sübedei died in 1248, when he was 72/73 years old (Yüan Shih, Chapter 121, 1a-5a). Jebe probably died after 1231, when he was sent by Ögedei to invade Northern China (MNT, 2004:95[\$272]). 
Georgio-Armenian lords, after their defeat of the Qipchaks, continued their expeditions to the city of Gandzak and to Azerbaijan in 1222-1225. ${ }^{51}$ However, they faced another danger from Jalāl al-Dīn Khwārazm-Shāh. In 1225, after his failure to find shelter in northern India, Jalāl al-Dīn returned to Iran, taking part of Khuzistan and then Azerbaijan (Maragha and Tabriz). ${ }^{52}$ Taking advantage of the situation following the Georgians' defeat by the Mongols, he also took the cities of Dvin, Gandzak, Nakhichevan, Lorii and Tiflis. ${ }^{53}$ After a short break, in 1226 he failed to capture Ani, Kars, Khlat and Manazkert (Manzikert/Malāzgird)..$^{54}$

The next Mongol general to be sent in pursuit of Jalāl al-Dīn $\mathrm{Kh}^{\mathrm{w}}$ ārazm-Shāh was Chormaghan (Chormaghun) (fl. 1218-1242). Chormaghan came to Armenia as a conqueror after invading Turkistan and northern Iran. The lands he controlled in Iran and Transcaucasia later paved the way for the Chinggisids to establish the Il-Khanate in the 1250s. In the Secret History of the Mongols, he was known as Chormaghan Qorchi (Quiver-bearer) of the Öteged tribe ${ }^{55}$ or of the Sunit tribe according to Rashīd al-Dīn. ${ }^{56}$

When Jochi, Chaghatai and Ögedei, the three eldest sons of Chinggis Khan, joined the latter in Țāliqān in 1221, after they brought the Khwārazmian capital Gurganj into submission but failed to set aside a share for Chinggis Khan, the latter condemned them. Chormaghan Qorchi, along with two other qorchis, Qongqai and Qongtaqar, supplicated Chinggis Khan as follows:

Like young falcons about to enter training, your sons are on the point of learning how to go to war. Why then do you reprimand your sons and constantly dishearten them? We fear that your sons, being afraid, will neglect their thoughts. Our enemies extend from where the sun sets to where it rises. When you incite us, your huge sheep-hounds [generals], go out against the enemy, Heaven and Earth increase our

${ }^{51}$ Sebastats'i in Hakobyan, 1956:138; Vardan Arevelts'i, 1991:142-143.

52 Ibn al-Athīr, 1940:153-155; Manandian, 1952:187.

${ }^{53}$ Melikset-bek, 1936:52-53; Ibn al-Athir, 1940:158-159; Kirakos Gandzakets'i, 1961:226. Gandzak city was plundered many times in 1225, first by the Georgians (Ibn al-Athīr, 1940:151), followed by the Khwārazm-Shāh, pursued by the Mongols, and later, in 1231, by Chormaghan (Vardan Arevelts'i, 1991:144).

${ }^{54}$ Manandian, 1952:190.

${ }^{55}$ SHM, 2001:253. Qorchi is transcribed as $\eta n\llcorner p<$ (ghurchi) in Kirakos Gandzakets'i, 1961:279.

${ }^{56}$ Rashīd al-Dīn, 1952(Vol. 1, part 1):98. 
strength and our one wish is to bring you gold, silver, satin and other goods, together with people and kinsmen. If you ask, 'Which people?' we reply that the presence of Caliph-sultan of the people of Baghdad is reported in the west-let us go to war against him... He [Chinggis Khan] sent Chormaghan to attack the Baghdad people and the Caliphsultan. ${ }^{57}$

From this account, it is apparent that firstly, Chormaghan was a high-ranking commander very close to the great Khan, even able to petition him, and secondly, that Chinggis Khan sent Chormaghan to complete the conquest of north-western Iran. Since Chormaghan was quite sure about the wealth of that region, one can speculate that he had already participated in the expeditions to the Middle East and knew the terrain and most likely was with Jebe and Sübedei in their first reconnoitering raid to the Caucasus. ${ }^{58}$

The fact that Chormaghan was sent to this region by Chinggis Khan is confirmed by Grigor Aknerts' $i$. In his narrative, he says that Chormaghan departed from Armenia and went back to Chinggis Khan, who approved his peaceful proposal to stay in the land of Armenia and 'gave C'awrman his kindly wife Aylt'ana Xat' 'un [Altuna Xatun] and dubbed him Č'awrmaghan. ${ }^{59}$

Later, in 1229, Ögedei Khan (r. 1229-1241), who succeeded his father as Great Khan, sent in 1229 another two commanders, Ogotor and Mönqetü, as rearguards for Chormaghan while the latter was campaigning against Jalāl al-Dīn. ${ }^{60}$ According to Juvaynī, Ögedei dispatched armies to all the countries of the world and sent Chormaghan with a number of amirs and 30,000 warriors to

${ }^{57}$ MNT, 2004:91(\$260); SHM, 2001:252.

${ }^{58}$ The same conclusion has been reached by May, 1996:14.

${ }^{59}$ Grigor Aknerts'i, 1974:25. Babayan argues that Chormaghan departed to meet Ögedei Khan not Chinggis Khan, who died in 1227, and that Grigor Aknerts'i mistook the names of the Mongol Khans (Babayan, 1969:144). In my opinion, his argument is not plausible, since the Secret History of the Mongols supports Grigor's statement (MNT, 2004:91[\$260]; SHM, 2001:252). The event described by Grigor Aknerts'i does not suggest that it happened after 1227 and examples of Chinggis Khan presenting a wife to his generals and vassals are found frequently in the Secret History of the Mongols. Cleaves suggests that ghan / qan added to Chorman may be used to indicate precisely the degree of affection and intimacy applied in the Armenian text. For names, see Cleaves, 1954:151, 132-175. Aylt'ana (Altuna) Xatun or Eltina Xatun (in Kirakos Gandzakets'i) was a pro-Christian wife of Chormaghan who held authority after her husband's deafness in 1242 (Kirakos Gandzakets'i, 1961:290).

${ }^{60}$ MNT, 2004:147(\$270); SHM, 2001:262. The set of triples applies in this case as well. 
Khurasan (Khurāsān) and Iraq, where Sultan Jalāl al-Dīn was still active ${ }^{61}$ In September and October 1229, Jalāl al-Dīn Khwārazm-Shāh took Khlat. ${ }^{62}$ Soon after retreating from the onslaught of Chormaghan, Jalāl al-Din fled to Amida. He was probably killed there in 1231 by local bandits. ${ }^{63}$ The most powerful opponent of the Mongols in this region was thus eliminated. ${ }^{64}$

In 1230, three years after Chinggis Khan's death, Azerbaijan was already permanently reoccupied under Commander Chormaghan. ${ }^{65}$ He set up his camp with all its families, goods and herds in the fruitful and fertile plain of Mughan. ${ }^{66}$ Ögedei-Khan issued a decree that Chormaghan should remain in that land as garrison commander. ${ }^{67}$ Azerbaijan was found to be a very suitable place to settle. Strategically, it was important because of its pasturelands. Moreover, it was a crossing point connecting Iran with Armenia and Georgia.

Mongol activity in the Caucasus, recorded in connection with Chormaghan in 1231, started with the conquest of the city of Gandzak. There is disagreement in Armenian sources over the date of capture of the city of Gandzak by Chormaghan. Mkhit'ar Ayrivanets'i says nothing about the capture of Gandzak. Grigor Aknerts'i states that it happened three years after the Kotman valley battle (in 1224), which is less certain. ${ }^{68}$ Sebastats'i says it happened in $1229 .{ }^{69}$ Kirakos Gandzakets i does not give any precise date, stating that, after the capture of the city the Mongols departed and a few

${ }^{61}$ Juvaynī/Boyle, 1997:190.

${ }_{62}$ Nasawī, 1996:240-243.

${ }^{63}$ According to Vardan Arevelts'i, Jalāl al-Dīn fled towards Amida (modern Diyarbakir/Diyārbakr) and died there (Vardan Arevelts'i, 1991:144). According to Nasawī, Jalāl al-Dīn was captured in the mountains of Amida and was killed by the Kurds (Nasawī, 1996:287).

${ }^{64}$ At that time, Chormaghan occupied most of Iran above the 32nd parallel. Chormaghan already controlled Khurasan, Mazandaran, Kirman, and Fars as well as Ray, Qum and Hamadan. Isfahan held out until 1237 (May, 1996:23, 31).

65 Patton, 1991:52.

${ }^{66}$ Kirakos Gandzakets'i, 1961:234-235.

${ }^{67}$ As tamghachi, in MNT, 2004:96(\$274); SHM, 2001:267. The Great Khan, knowing that the land was said to be good and its possessions fine, ordered Chormaghan to send him each year yellow gold, gilt, naqut (gold brocade), brocades, damask, small pearls, large pearls, sleek Arab horses with long necks and legs, dull brown work-horses, camels, small-humped camels, pack-mules and riding mules (MNT, 2004:96(\$274); SHM, 2001:267. When Khurasan was subjugated, Ögedei-Khan was told about the wrestlers of Khurasan and Iraq, and he sent a messenger to Chormaghan and ordered him to send one of them (Juvaynī/Boyle, 1997:227).

${ }^{68}$ Grigor Aknerts'i, 1974:21.

${ }^{69}$ Sebastats'i in Hakobyan, 1956:139. 
years after the destruction of Gandzak the Mongol army divided up the lands of Armenia, Georgia and Albania by lots. He continues that the city remained desolate for four years and then the Mongols ordered the citizens to rebuild it. ${ }^{70}$ Based on Step'annos Orbelian's Chronicles, Manandian argues that Gandzak was plundered by Chormaghan in $1231 .{ }^{71}$ The most plausible year of 680 Arm. (1231) is found in the Annals by Step annos Episkopos ${ }^{72}$ because the capture of Gandzak happened after Chormaghan had disposed of the remnants of the Khwārazm-Shāh in 1231 and the great camp of Chormaghan was transferred to the city of Gandzak, which had previously been devastated and afterwards restored. ${ }^{73}$

In Armenian sources, the name of the city of Gandzak is recorded in two different ways, Gandzak and Gandzak-shahastan [shahristān]. Vardan Arevelts'i and Sebastats'i mention Gandzak-shahastan. ${ }^{74}$

According to Sebastats'i, in 1229, 'countless multitudes under the leadership of Charmaghan entered Gandzak-shahastan, seized it and brutally slaughtered the inhabitants, taking women and children into captivity. Mystical pictures of their plunder appeared: the earth cracked and black water came out; a poplar tree (dun uh unuh) called chandari, which was near the city turned around and stood again as before; this has happened three times, then it fell and did not stand any more. ${ }^{75}$ A similar story is found in earlier work of Kirakos Gandzakets' $i$, where he describes Gandzak as a city densely populated with Iranians and a small number of Christians. He says that before the Mongols arrived, 'an extremely large poplar tree (dun uh uou h), chandari, had turned around three times; suddenly the T'at'ars arrived and besieged the city of Gandzak with numerous war machines from all sides for a week. After the capture they departed. ${ }^{376}$

70 Kirakos Gandzakets'i, 1961:235-237.

71 Manandian, 1952:194.

72 Step'annos Episkopos, 1951:40.

73 Grigor Aknerts'i, 1974:26.

74 Shahastan is an Armenian borrowing from Persian shahristān, large fortified city (Sanjian, 1969:453). Patkanov claims that Gandzak-shahastan in Armenian sources stands for the city of Tabriz, which is not relevant to our case (Patkanov, 1873:117(n.10). However, in Orbelian, Tabriz is called Davrezh shahastan (Step'annos Orbelian, 1910:419). In Vardan Arevelts'i the scribe mistook the year, in 1225, Gandzak was taken by Jalāl al-Dīn, not by Chormaghan (Sebastats'i in Hakobyan, 1956:138).

75 Sebastats'i in Hakobyan, 1956:139. One assumes that this natural phenomenon was an allegorical prediction of disaster or calamity.

76 Kirakos Gandzakets'i, 1961:235-237. 
Armenian sources provide only scarce information about Chormaghan's activities in the Caucasus from 1231 until 1236. One of the Armenian colophons, dated 1231, states:

In this year appeared a nation called $\mathrm{T}^{\prime}$ at'ar, [which] caused the Persian king [Jalāl al-Dīn] to flee, who plundered the land of Persia and reached the Mediterranean lands as far as the places Edessa and Samosat, slaughtered many Turks, Kurds and Christians, and besieged many. ${ }^{77}$

Step'annos Episkopos states that, in 680 Arm. (1232), the Mongols entered Khlat and destroyed much. ${ }^{78}$ Kirakos Gandzakets'i mentions only the fact that the disorder in Armenia increased because Commander Chormaghan had become deaf from his wounds. His disability may explain why Chormaghan did not complete his task of subduing the 'people of Baghdad' and the caliph, which was a major reason for him to be sent to Western Asia by the order of Chinggis Khan. ${ }^{79}$ However, from 1232 he was steadily approaching to Greater Armenia. Until 1242, Chormaghan was in charge of all affairs in the region. After his sickness, his wife, together with his children, and officials, held authority in the region. ${ }^{80}$

\section{The Mongol Noyans in the Land of the Armenians}

As stated earlier, according to Juvaynī, Chormaghan came to the region with an army of three tumans or 30,000 men. ${ }^{81}$ The number of this detachment assumes that there were three main commanders in charge of a tuman or 30 commanders in charge of every 1,000 soldiers, although it is not clear how many of them Chormaghan placed in Armenia. However, it is fortunate that Armenian historians provide some of the names of Mongol noyans (commanders) to whom Armenian land was allotted in 1236. These noyans in a short, one-year period conquered the northern and eastern parts of Armenia, which were under the Georgian crown. According to contemporary Armenian sources, Georgian and Armenian lords chose less destructive ways to resist the Mongols. The Georgian Queen Rusudan (r. 1223-1245) was a witness to Chormaghan's presence in

\footnotetext{
77 Mat'evosyan, 1984:175.

78 Step'annos Episkopos, 1951:40.

79 MNT, 2004:91(\$260), 94(\$270).

80 Kirakos Gandzakets`i, 1961:265.

81 Juvaynī/Boyle, 1997:190.
} 
the region. She and many lords of Georgia and Armenia fled to their fortresses in fear of the Mongols. ${ }^{82}$ This withdrawal gave the Mongols a chance to chase the fugitives using their own famous tactics: Dividing districts up among themselves and conquering them one by one. This implies that the Mongols knew the terrain well before they conquered it.

Grigor Aknerts'i records that ' 110 chieftains' with winter residences in Mughan divided the country and that 'thirteen chieftains divided the countries of the Georgians and the Albanians, highland and lowland, among themselves. ${ }^{83}$ The main organiser of this conquest remained Chormaghan, who, at that time, had established himself on the shores of Lake Geghark'unik' (Sevan). ${ }^{84}$ According to contemporary Armenian sources, Chormaghan sent out his military detachments under various noyans to capture the key fortresses of the Armenian lords. Kirakos Gandzakets'i gives extended accounts of the Mongol noyans' siege of the cities and fortresses one by one and of the techniques they applied. ${ }^{85}$ The following includes descriptions of the Mongol noyans' conquest of the Armenian lands according to their order of submission.

The lands of Awag Zak'arian, the son of Iwanē, were taken by Itughata Noyan from the Jalayir tribe, whose name is also given as Tulata (Dolata). ${ }^{86}$ Awag Zak'arian fled to his fortress Kayen along with the people of the district. Itughata Noyan and his men blocked the access to water of the fortress and commanded the 'people to come down and live among them,' which was another technique applied by the Mongols to force castles and their inhabitants to surrender ${ }^{87}$ Kirakos Gandzakets $i$ describes the way the inhabitants and animals, cut off from the water supply, began to suffer from thirst and the Mongol noyan gradually took their horses and all their livestock, which were valuable to the Mongols. ${ }^{88}$

The lands of Vahram Gagets'i, a nephew of Iwanē' Zak'arian, consisting of the city of Shamkor, the fortresses of Tavush, Katsaret', Terunakan, Ergavank', and the impregnable forts of Gavazin and

${ }^{82}$ Mkhit'ar Ayrivanets'i, 1860:66.

${ }^{83}$ Grigor Aknerts'i, 1974:26.

${ }^{84}$ Ibid., 255.

${ }^{85}$ Kirakos Gandzakets 'i, 1961:241-243, 253-255, 258-261.

${ }^{86}$ Rashīd al-Dīn, 1952(Vol. 1, part 1):98; Dolata Noyan, in Vardan Arevelts'i, 1991:144.

${ }^{87}$ Kirakos Gandzakets'i, 1961:255.

${ }^{88}$ Ibid., 255. 
Gag $^{89}$ fell to the lot of Molar Noyan, or probably Molghor Noyan, who was from the Sunit tribe (see Map 4). ${ }^{90}$

The Mongols' main tactic in taking the cities was to surround the location or block the entrance to the city, as Molar Noyan did with the city of Shamkor. The city was under the authority of Vahram and his son Aghbugha, who were in Gardman at the time of the Mongol siege and who refused to help the residents of Shamkor despite their appeal. Moreover, Vahram ordered them not to resist. Molar Noyan ordered his men to fill the trench that surrounded the city walls with wood and branches so that they might easily climb onto the walls. However, at night the citizens of Shamkor hurled down fire and burned the brushwood. Seeing this, Molar ordered each soldier to bring a load of soil and to throw it into the trench until it reached the level of the wall. ${ }^{11}$ After the capture of Shamkor, Molar Noyan attacked the Kiurikian Prince Vasak's fortress of Matsnaberd and Nor Berd. ${ }^{92}$

The Zak'arid city of Lori fell into the hands of Chaghatai Noyan of the Arulat tribe. ${ }^{93}$ It is recorded in the sources that Chaghatai had heard about the fortifications of Lori because Prince Shahnshah Zak'arian had kept his treasury there. ${ }^{94}$ Prince Shahnshah himself fled westwards to Adjaria with his family, leaving the city under the supervision of his father-in-law. ${ }^{95}$ After all his preparations, Chaghatai Noyan ordered his men to dig at the base of the walls of the city until they collapsed. This was another effective Mongol tactic for besieging cities and fortresses. Chaghatai Noyan took the city and Shahnshah's treasure and he did the same to the cities of Dumanis, Shamshulde and Tiflis. ${ }^{96}$

${ }^{89}$ Ibid., 241, 263. On the Zak'arid Princedoms, see Babayan, 1976:541-550. The first cousin of Iwanē and Zak'arē Zak'arians, named also Zak'arēe, ruled lands in Tawush, P'aŕisos and Gardman. The centre of his realm was Gag fortress. This line became known as Vahramean after Zak'arē Gaghets'i’s son, Vahram of Gag (Babayan, 1976:541).

${ }_{90}$ Rashīd al-Dīn, 1952(Vol. 1):100.

91 Kirakos Gandzakets'i, 1961:241-242.

${ }_{92}$ Ibid., 243; Vardan Arevelts'i, 1991:144.

${ }_{93}$ Rashīd al-Dīn, 1952(Vol. 1):100.

${ }^{94}$ Vardan Arevelts'i, 1991:144; Kirakos Gandzakets'i, 1961:253.

${ }_{95}$ Melikset-bek, 1936:54.

${ }^{96}$ Kirakos Gandzakets'i, 1961:253-254. 
In the same way, the city of the Surb Mari (Holy/Blessed Mary) fell under Qara Noyan or Ghara Baghatur from the Baarin/Sukanut tribe. ${ }^{97}$ The city had been under the rule of Shahnshah [and Awag]. ${ }^{98}$

The cities of Ani and Kars, the centres of Zak'arid authority, were looted and captured by Chormaghan, who used the catapults and siege techniques in bringing down the fortresses. ${ }^{99}$

The same applied to the territories of Utik: Gardman, Charek (the northern part of Artsakh), Getabak and Vardanashat (southern Utik), ${ }^{100}$ fell into the hands of Ghatagha Noyan, who was perhaps Ghadaqan Qorchi or Qatagan, a relative of Jebe, from the Besüt tribe. ${ }^{101}$

The lands of Khachen, namely the fortress of Khokhanaberd, fell to Jukh-Bugha Noyan. ${ }^{102}$ He waged war against fortified places filled with fugitives and the people of Prince Hasan Jalal, a nephew of Zak'arē and Iwanē, using a massive army with many siege machines and weapons, enslaving or killing those he defeated. ${ }^{103}$

In almost all cases in which the Mongols undertook a siege, this was followed by negotiations with the Armenian lords, requiring them to submit in exchange for sparing their possessions, including their lands and people. However, it was not always true that, after a voluntary submission, the Mongols kept their promises, as happened with the city of Kars. After learning what the Mongols had done to Ani, the inhabitants of the city of Kars hastened to give the keys of the city to them in the hope that they might be spared. Nevertheless, the destiny of Kars was similar to that of Ani, though not because of the booty that attracted the Mongols. Perhaps in order to discourage densely populated cities from confronting and resisting in future, the Mongols slaughtered the inhabitants, took some residents into captivity, and then ravaged and ruined the city. ${ }^{104}$ However, after the Mongols had left the cities, the troops of the Sultan of Rūm, Ghiyāth

\footnotetext{
${ }^{97}$ Rashīd al-Dīn, 1952(Vol. 1):189; Kirakos Gandzakets‘i, 1961:260-261.

98 Step'annos Episkopos, 1951:41.

${ }_{99}$ Kirakos Gandzakets'i, 1961:258-59.

100 Vardan Arevelts'i, 1991:144.

101 Rashīd al-Dīn, 1952(Vol. 1):195; Ghadaghan Qorchi in Juvaynī/Boyle, 1997:590.

${ }^{102}$ The origin of Jukh-Bugha is uncertain.

103 This information is not found in primary sources, but is mentioned in Chamchiants, 1789/1984:210.

104 This slaughter might have had the opposite effect, encouraging resistance or revolt, because the population would be killed anyway.
} 
al-Dīn Kay Khusraw II (1237-1246), arrived and mercilessly led into slavery those who had escaped the Mongols. ${ }^{105}$

On the whole, the Mongols took fortresses and cities without having to engage in large battles. The occupation of the Armenian lands in general did not last long. The Armenian lords were clever enough to show their loyalty to the conquerors and in this way did get back their lands, as was the case with the Orbelians, who retained Siwnik' province ${ }^{106}$ which had fallen into the hands of Aslan (Arslan) Noyan. ${ }^{107}$ This happened in a very exclusive manner: In 1236, Elikum, the eldest son of Liparit and one of the Siwnik' princes, fortified the impregnable fortress of Hrashkaberd. Having found that it was impossible to capture this fort, Aslan Noyan sent messengers to negotiate with Elikum, saying that as he would not leave this land, given him by God, 'the sooner you and your family come out to us the better and you will be rewarded.' Elikum agreed with this proposal and asking for his safety to be assured, he went with many gifts to Aslan Noyan. Seeing this, the Mongol commander received Elikum with honour and, moreover, appointed him as a leader of his troops. Aslan Noyan and Elikum subjugated all lands up to the city of Ani: Vayots' Dzor, Eghegis up to Ereron, a village situated opposite Garni. However, all these lands Aslan Noyan returned to Elikum saying that 'both those taken by the sword and those purchased by gold are equally the dominion of the people, now whatever place may be taken by my sword will be your patrimony. ${ }^{108}$ After that, these lands came under the dominion of the house of the Orbelians.

Single or individual submissions by Armenian lords and their direct negotiations with local Mongol governors made it easy for the Mongols to divide and rule. However, this brought about a unique situation where the land was formally under Mongol overlordship

\footnotetext{
${ }^{105}$ Kirakos Gandzakets'i, 1961:260.

106 After the death of King Gregory IV (ca. 1105/1124-ca. 1166), the territories of the kingdom of Siwnik' passed to the Muslims. Around 1200, Elikum I Orbelian received the Siwnik' districts of Chahuk and Ernjak (Julfa) from the atabeg of Azerbaijan. Liparit, the son of Elikum was granted by the Georgian Queen T'amar the districts of Orotn (Vorotn) and Bargiwshat in addition to Hrashkaberd in Chahuk. Elikum II (d. 1243) obtained from the Mongol noyan Aslan Vayots' Dzor and Egeis in 1236. Elikum's brother Smbat II (1243-1273) received from the Mongols Orotn, Egegis, Vayots' Dzor, Urts, Vedi and other lands (Step'annos Orbelian, 1910:404; Hewsen, 1975-1976:220-221; Grigoryan, 1990:65-69, 84-89).

107 According to Armenian and Muslim sources, the origin of Arslan is impossible to identify.

108 Step'annos Orbelian, 1910:404.
} 
but was actually ruled by local Armenian lords. The forms of administrative institutions in Greater Armenia will be analysed in Chapter Four.

To sum up, the course of 1236, the Mongol commanders conquered the Georgian territories of the Zak'arids, along with the regions of Geghark'unik' (Sevan), Arts'akh, Siwnik', Khachen, and Utik; the cities of Ani, Kars, and Kayen; Shirvan with the city of Shamakha; Arran with the cities of Gandzak (Ganja) and Shamkor; Mughan and Azerbaijan (see Map 4). Thus, the Mongols' conquest of eastern and northern Armenia progressed either by force or by negotiation and met with no major opposition.

\section{The Final Mongol Conquest of Armenia by Baiju and Its Impact on} the Armenian Kingdom of Cilicia (1242-1245)

As was mentioned, the Mongols' conquest of eastern and northern Armenia progressed either by force or by negotiation and met with no major opposition. From 1242 to 1245, the Mongols advanced further to the west and south of Armenia. At the beginning of 691 Arm. (1242), because of his deafness, Chormaghan was replaced by Baiju Noyan from the Yisüt/Besüt tribe. ${ }^{109}$ After Baiju had assumed authority, he mustered troops from all of the peoples under his dominion and went to the western part of Greater Armenia, which at that time was under the dominion of the Sultan of Rūm, Ghiyāth al-Dīn Kay Khusraw II (r. 1237-1246). ${ }^{110}$ In 1242/1243, Baiju first besieged T'eodupolis (Karin/Erzurum), erecting numerous catapults and ordering his men to demolish the city walls. ${ }^{111}$ According to Kirakos Gandzakets'i, he demolished the city walls and mercilessly

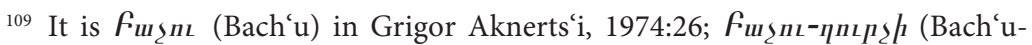

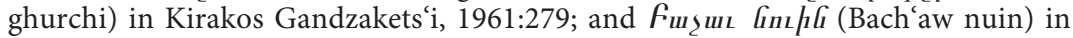
Vardan Arevelts'i, 1991:147. Western travellers depicted his name as Baachu (Rubruck in Komroff, 1989:200-201; Rubruck, 1990:263). Baiju was a relative of Jebe; he was appointed as commander by Ögedei Khan and participated in the capture of Baghdad with Hülegü (Rashīd al-Dīn, 1952 [Vol. 1, part 1]:99). Baiju is one of the Mongol noyans with extensive references in Arabic, Seljuk, Persian and Armenian sources (Korobeinikov, 2002:126-129). In 1254, one of Baiju's residences was in the city of Kars (Kirakos Gandzakets'i, 1961:367). Baiju stayed as chief commander in Armenia until 1257 (Kirakos Gandzakets'i, 1961:374). Mamluk sources say that Baiju was converted to Islam (Melville, 2009:51-101).

${ }_{110}$ Kirakos Gandzakets'i, 1961:279; Manandian, 1952:219.

111 Grigor Aknerts'i wrongly dates the siege of Karin by Baiju to 688 Arm. (1239). 
put everyone to the sword. Baiju's army destroyed goods and property and set fire to the city in revenge for the perceived insult to the Mongol ambassadors sent to demand a peaceful submission. At that time, the city was densely populated by several different communities, Christians and Muslim. ${ }^{112}$ With regard to the Christians, it is said that in the city there were many valuable Gospels written in gold; the Mongols took the valuable ones and sold them cheaply to the Christians amongst their troops, who then distributed them to their own district churches and monasteries. ${ }^{113}$ The Armenian Princes Awag, Shahnshah, Vahram's son Aghbugha, and Dop'i’s son Grigor Khachenets'i, ransomed from captivity as many men, women, children, bishops, priests and deacons as they could. ${ }^{114}$

After the two-month siege of Karin (Erzurum), the key to expansion to Asia Minor, Baiju destroyed many other districts under the rule of the Sultan of Rūm and returned to Mughan with much booty. ${ }^{115}$ He spent the Winter at his base in Azerbaijan, but in the Spring of 1243, he returned to crush the forces of the Seljuk Sultan of Rūm, Ghiyāth al-Dīn Kay Khusraw at Köse Dagh, near Erznka (Erzinjan/ Erzincan). ${ }^{116}$

The cause of this battle that occurred in June 1243, according to Kirakos Gandzakets'i, was the boastful and threatening words of Ghiyāth al-Dīn who said that next Summer the Sultan would come over the Mughan plain with his women and soldiers to Winter there. ${ }^{117}$ When the Mongols heard this, after grazing their horses, they gradually gathered their troops and approached the camp of the Sultan, which was near the village named Ch'mankatuk or Köse Dagh. ${ }^{118}$ The Sultan was there 'with a countless multitude, with women and concubines, gold and silver' and all his valuable possessions. ${ }^{119} \mathrm{He}$ had

\footnotetext{
112 Kirakos Gandzakets'i, 1961:279.

113 Grigor Aknerts'i, 1974:28.

114 Kirakos Gandzakets'i, 1961:280.

115 Ibid., 280. Step'annos Episkopos states that, after the capture of Karin, the Mongols took with them many of the writings [manuscripts] and church ornaments (Step'annos Episkopos, 1951:41).

${ }_{116}$ Cahen, 1968:138.

117 Kirakos Gandzakets'i, 1961:281.

118 According to Armenian sources, the battle took place on a plain situated between Karin (Erzurum) and Erznkay[n] (Erzinjan) (Grigor Aknerts'i, 1974:29). Kirakos Gandzakets'i names the place Ch'man-katuk, which Manandian believes is the present day village of Chimin, east of Erznka (Manandian, 1952:215). The place is called كوسه دا (Bald Mountain or Köse Dagh) by Rashīd al-Dīn, 1946:33.

119 Kirakos Gandzakets'i, 1961:281-283.
} 
appealed for reinforcements to his vassals and allies, the rulers of Aleppo, Trebizond, Nicaea, Cilician Armenia and the 'Frankish' warriors and knights from the Crusader states. According to Het'um, the historian, the Sultan promised gifts to all. ${ }^{120}$ However, the Cilician Armenian reinforcements delayed joining him and the Sultan went without waiting for them. ${ }^{121}$ The delay was caused by the fact that there was a disagreement among the Cilician Armenian lords about this war. ${ }^{122}$ King Het'um I had seen already that the Mongol army was a far more serious opponent than the Seljuk sultan. The size of the Sultan's army was 160,000 men according to Grigor Aknerts 'i. ${ }^{123}$ Friar William of Rubruck gives a different number. In his journey from Mongolia in 1254/1255, he passed through the valley in which he says 200,000 men of the Sultan were defeated by the Tatar army of $10,000 \cdot{ }^{124}$ Het' um, the historian, has 30,000 for the size of the Tatar army for this incident. ${ }^{125}$

Although the Mongols were outnumbered, General Baiju divided his soldiers, putting them under pre-eminent and brave commanders. To avoid treachery, he mingled the troops who were made up of various nationalities. Then, selecting the most valiant and brave ones, he organised a vanguard, which battled with the Sultan's troops, causing the Sultan to flee. ${ }^{126}$ If Kirakos attributes the success in Köse Dagh to Baiju's profound knowledge of warfare, Grigor Aknerts'i attributes the victory to the Georgio-Armenian army. ${ }^{127}$ According to Āqsarā' $\overline{1}$, the cause of the Seljuks' failure in Köse Dagh was disunity within the Sultanate. ${ }^{128}$ Ibn Bìbī is in agreement with this; he says that various discords and upheavals within the Seljuk state led to the defeat. ${ }^{129}$ The Anonymous Seljuk author blames the Seljuk sultan for his passivity and his amirs for their imperious advice,

\footnotetext{
${ }^{120}$ Het'um Patmich', 1842:38.

${ }^{121}$ Cahen, 1968:137.

122 Ibid., 270.

${ }^{123}$ Grigor Aknerts'i, 1974:29.

124 Rubruck in Komroff, 1989:205. The more reliable number for the Sultan's army is 80,000 and 30,000 for that of the Mongols; Rubruck, 1990:272.

${ }^{125}$ Het'um Patmich', 1842:38.

126 The Sultan escaped to Ankara seeking further assistance, while his mother, wife and daughter sought refuge in Cilicia. Kay-Khusraw died in the winter of 12451246 (Cahen, 1968:138, 271).

127 Kirakos Gandzakets'i, 1961:281-283; Grigor Aknerts'i, 1974:29.

128 Āqsarā'î̀, 1944:61-62.

129 Ibn Bībī, 1956:510-512; Melville, 2006b:158.
} 
which aided the Mongols' triumph in Köse Dagh. ${ }^{130}$ The sources put forward the advantages and disadvantages for the battle from their own points of view.

After this victory at Köse Dagh, the Mongols under Baiju besieged Caesarea (Kayseri/Qaysāriyya) in Cappadocia. ${ }^{131}$ Then they came to Sebastia (Sivas); since the inhabitants had surrendered in advance, coming out with gifts and presents, the people were spared, although part of the city was looted. After conquering the city, the Mongols set up overseers and left. ${ }^{132}$

The defeat of the Seljuks at Köse Dagh had important political consequences for the history of Asia Minor. ${ }^{133}$ It was the turning point which led to the submission of the Seljuk Sultanate of Rum to the Mongols. ${ }^{134}$ Baiju established himself as the representative of the Great Khan in the lands of Armenia, Georgia, Azerbaijan, Syria, Rūm and Western Iran.

By 1243, the major cities of central Asia Minor, Erznka, Melitene and Divriği had also fallen to the Mongols. In 1244, Baiju started to launch a number of raids on Ayyubid territory, as he moved south. In 1245, Baiju Noyan captured Khlat, which was under the political domination of the Ayyubids, and also Amida, Uŕha (Ruha/Edessa), and Nașīiin (Nisibis). ${ }^{135}$ After the submission of the Seljuk Sultanate to the Mongols, Baiju held an important position among Mongol representatives in West Asia. In May 1247, Baiju received an embassy from Innocent IV (1243-1254) headed by the Dominican monk Ascelin. ${ }^{136}$ According to the letter sent to Pope Innocent IV in July 1247, Baiju had a residence in Sisian, near Nakhichevan. ${ }^{137}$ In 1254 ,

${ }^{130}$ Melville, 2006b:158.

${ }_{131}$ When the inhabitants did not surrender, the Mongols took the cities forcibly and put the populations to the sword, destroying whatever was in the cities and leaving them deserted (Vardan Arevelts'i, 1991:147).

${ }_{132}$ Kirakos Gandzakets'i, 1961:281-283; Vardan Arevelts'i, 1991:147; for overseers, see Chapter 4 .

${ }^{133}$ Cahen, 1968:138.

${ }^{134}$ In $642 \mathrm{H}$. (1244), the Seljuks issued a new coinage in Rūm to pay tribute money to the Mongols (Kolbas, 2006:123).

${ }^{135}$ In 694 Arm. (1245), the Mongols captured Khlat, and handed it over to T'amt'a, the sister of Awag, who was a former ruler of the city after her marriage to Ashrap' Melik (Kirakos Gandzakets'i, 1961:292-293). She was sent to the Mongol Khan and stayed there for many years (Sebastats'i in Galstyan, 1962:26).

136 Saint-Quentin, 1965:94-118.

${ }_{137}$ Ibid., 115; Lupprian, 1981:190; Rubruck, 1990:31; Korobeinikov, 2002:126. 
one of his residences was in the city of Kars. ${ }^{138}$ Baiju stayed as chief commander in Armenia until 1257. ${ }^{139}$ Later, in 1258, he participated actively in the Mongol campaign against the caliph of Baghdad. ${ }^{140}$

By the middle of the thirteenth century, all of Greater Armenia had fallen under the rule of the Mongol noyans. Further names of Mongol noyans who were allotted Armenian lands are given by Grigor Aknerts'i, namely Khul/Xul, (who 'called himself a brother of God'), Balakhē, Tut'ar, T'agughar, Ghataghan, Bawraghan, Asut'u (who was the companion of the Khan), Chaghatai (who was surnamed Khan), Sanit'ay, little Chaghatai, Asar, Xut't'u, T'ut'tu, Awgawtai, Xojay, Xurumchi, Xunan, T'enal, and Angurag. ${ }^{141}$ Many on this list are not found in other contemporary Armenian sources. Since the names are mentioned briefly, it is difficult to identify who was whom, although Awgawtai, Xojay, Xurumchi, Angurag and many others might have been well-known people in Mongol and Muslim sources. Yet another spelling of Ghataghan as Ghada-khan who raided the city of Khamakh in 705 Arm. (1256) is found in Sebastats ${ }^{\prime}$ i. ${ }^{142}$ Step'annos Episkopos mentions the same Ghada-khan who destroyed the city of Erznka in 706 Arm. (1257). ${ }^{143}$ In his Chronicles, the seventeenth-century author David Baghishets'i gives the names of Fulpuup (Iskrar) Noyan and 2numnzis (Ghutun) Noyan, together with Chormaghan. ${ }^{144}$ It is worth noting that a Mongol noyan Eljigidei is mentioned by Kirakos only once as $E_{l} h^{-}$ quinu (Elch'i-Gada), whilst he talks about the revolt against Möngke Khan by the Mongol princes. It implies that the Mongol commander Eljigidei (Eljigidai) ${ }^{145}$ was not well known to the Armenians. Eljigidei, who had previously participated with Chinggis Khan in his expedition to Tangqut and China, was ordered by Güyük Khan (1246-1248)

\footnotetext{
${ }_{138}$ Kirakos Gandzakets i, 1961:367.

${ }_{139}$ Ibid., 374. On Baiju's activities in Anatolia after 1257, see Melville, 2009:51101.

${ }^{140}$ For the Mongol conquest of Baghdad, see Chapter 5.

${ }^{141}$ Grigor Aknerts'i, 1974:26, 38.

${ }^{142}$ Sebastats'i in Hakobyan, 1956:142.

${ }^{143}$ Step'annos Episkopos, 1962:35.

144 Davit' Baghishets'i, 1956:346.

145 According to Rashīd al-Dīn, there was a Mongol commander called Eljigidei, who was from Jalayir tribe and who was sent to Iran with instructions to assume supreme command in demolishing the Muslim forts, beginning with the Ismā'îlis (Rashīd al-Dīn, 1952(Vol. 1):95, 1960:120, 1996:50, 570. For Eljigideis, two Mongol generals, see Jackson, 1998a:366-367.
} 
to replace Baiju. ${ }^{146}$ Güyük appointed Eljigidei as his representative in the west, responsible for Anatolia, Georgia, Armenia, Aleppo and Mosul. He was dispatched to head the reinforcements for the Mongol armies already stationed there, so that the local rulers would be directly answerable to him for their tribute. ${ }^{147}$ However, his name is known initially from his message sent to Louis IX (1226-1270) in 1248, in which he wished success for the Crusade and gave assurance of protection for Christians under Mongol rule. ${ }^{148}$ While he was on the road to Iran, Eljigidei received news of the death of Güyük Khan and stayed where he was to see who would take the throne. Möngke Khan (1251-1259) was enthroned with the assistance of Batu Khan (d. 1255), the son of Jochi (d. 1227). ${ }^{149}$ According to Kirakos Gandzakets' $i$, learning that Eljigidei was among the rebel princes who were against his enthronement, Möngke Khan ordered Eljigidei to be sent to him. Eljigidei was seized and killed because among the rebel noyans were his two sons. ${ }^{150}$

In Cilician Armenia, the advance of the Mongol armies on the Sultanate of Rūm was watched with due care. Once the Mongols reached Erznka, a city close to the boundary of Cilicia, they destroyed it cruelly in revenge for the residents' resistance; ${ }^{151}$ the Armenian King Het'um I made a decision that greatly aided Cilician Armenia. On the one hand, he faced possible problems from Rome, as the papacy questioned the legitimacy of his marriage and insisted on his formal submission to the Roman Catholic Church. ${ }^{152}$ On the other hand, Iconium (Konya) and the Egyptian Sultanate waged war against the Near Eastern Crusader states and threatened to attack small Cilicia as the next target. ${ }^{153}$ Besides that, Het'um was aware of Greater Armenia's devastation at the hands of the Mongols, because thousands of Armenians had fled to Cilicia from Greater Armenia

\footnotetext{
146 MNT, 2004:305.

147 Melville, 2009:51-101.

${ }_{148}$ Jackson, 1998a:336, 1999:713-714. The envoys of Eljigidei claimed that Eljigidei and Güyük Khan were Christians. The letter was forwarded to Louis' mother, Queen Blanche in France, who in her turn forwarded it to the English King Henry III (1216-1272) (Jackson, 2005a:98-99).

${ }_{149}$ Kirakos Gandzakets'i, 1961:357.

${ }^{150}$ MNT, 2004:305.

151 Vardan Arevelts'i, 1991:147. According to Sebastats'i, Erznka was captured once by the Mongols in 1231 (Galstyan, 1962:24).

${ }^{152}$ Bundy, 1987:227.

${ }^{153}$ Der Nersessian, 1969:49.
} 
in order to escape the Mongol savagery. ${ }^{154}$ Similarly, he also learned that Georgia had been spared after the Georgian king's submission to the Mongols. Therefore, there were two options open to Het'um: Either he could choose an alliance with the papacy, which was in conflict with the national religious interest of the Armenians, or form an alliance with the Mongols before they overran his land. Both options were risky but the Armenian nobles and clergy supported Het'um's decision of voluntary submission to the Mongols. ${ }^{155}$ This was the most important event of the reign of Het'um I. He ruled Cilician Armenia for 44 years, the longest reign of any Cilician king. His brother Smbat Sparapet (Constable) and his father Baron Kostandin (Constantine), who lived for many years during his son's reign, played a great part in King Het'um's success. His own people respected Het'um as a wise monarch. ${ }^{156}$ Unlike his Western allies, Het'um did not waste time, but shrewdly analysed the shift in world and regional politics. ${ }^{157}$ At this time, the world experienced the fall of the Chin dynasty of the northern China and annexation of Korea (1231-1234) to the Mongols; the occupation of northern Iran (12301233); the conquest of central Russia (1237-1239); and the invasion of Ukraine, Poland and Hungary (1241). Now, the Mongols had overrun Anatolia. Het'um sought an alliance with the Mongols, understanding the necessity of establishing a new strategy to balance the Cilician position. He must have realised that by fostering a friendship with his immediate aggressor he could resist the neighbouring Muslim states and safeguard his relationship with the Catholics. Without delay, he sent his delegation, headed by Baron Kostandin, to Caesarea in 1243, in order to open negotiations with Baiju and Altuna-khatun, the wife of the late Chormaghan. ${ }^{158}$

\section{Factors that Impacted the Mongol Conquest of Armenia}

It is obvious that the lack of centralised power in the territory of Armenia attracted the Mongols, who were driven at that time by the imperial ideology of world conquest. Greater Armenia was found to

\footnotetext{
154 Galstyan, 1976:30.

155 Bundy, 1987:227.

156 Burger in Het'um, 1988:xvi.

157 Boase, 1978:25; Burger in Het'um, 1988:xvii.

158 Kirakos Gandzakets'i, 1961:285. For the negotiations, see Chapter 3.
} 
be on the crossroads connecting Iran with Anatolia and the Caucasus with the Russian steppes. Besides that, the Arran and Mughan fertile plain was just nearby and was used by the Mongols as a safe place to retreat to and from which to launch new campaigns. Therefore, from the strategic point of view, Greater Armenia was chosen as an important location to hold. Mongol scouting expeditions found Armenia a suitable place from which to mount campaigns not only into Georgia, but also into Anatolia, which was accomplished in 1243, bringing the Seljuk Sultanate of Rūm into submission. Armenia, as part of the region, was now incorporated into the Mongol Empire.

The attachment of Armenia to the Mongol Empire was brought about by conquering Armenian strongholds one by one, as the ishkhans took refuge in their fortresses. Pursuing the Armenian lords, the Mongol noyans brought them into submission either by the sword or through negotiation. The success of the invasion can be studied from various perspectives. Politically, the very passive rule of the Georgian Queen Rusudan and the absence of a unified defence policy for the country contributed to the victory of the Mongols in Armenia.

In practice, the Mongols' adoption of certain models of military tactics achieved success in the case of Greater Armenia as well. ${ }^{159}$ The target for attack was discussed carefully and sufficient time was allocated to preparing men and horses, as happened with Baiju before his march to Köse Dagh. The timing of expeditions was always related to the animals' grazing season, since the core of the Mongol army consisted of cavalry. Attacks on small citadels preceded attacks on key or big cities and fortresses, as in case of Molar Noyan in Armenia. The population of occupied lands was used as a supporting labour force or a home guard that reinforced the Mongol infantry, as was the case in Armenia, and these home guards participated in Chormaghan's and later in Baiju's conquests. ${ }^{160}$ Often, they were used as 'human arrow shields' and for handling the most dangerous war vehicles. ${ }^{161}$ Military weapons used by the Mongols were more

159 This general pattern for battles was applied in Central Asia and southern Russia (Vernadsky, 2001:122-126).

160 A local or domestic army was always in the vanguard, such as Awag's detachment used by Chormaghan to take Ani and Kars. Later on, Armenian and Georgian troops under Commander Baiju were placed in the front lines in the battle of Ch'mankatuk (Grigor Aknerts'i, 1974:29).

161 Koh Byong-ik, 1969:154. 
advanced than their opponents, especially for besieging fortresses. ${ }^{162}$ The mobility of the lightly-armed Mongol army was a crucial factor in defeating its more heavily-armed opponents. ${ }^{163}$

Psychologically, the Armenians were not ready to face the Mongols. As Kirakos Gandzakets'i states, the Armenians' hopes for the Mongols to be the avengers of the Christians from the tyranny of the Turks turned out to be false. ${ }^{164}$ Realising that the new enemy was unbeatable, they decided that God had given the Mongols power and the only way that was left for the Armenians was to reconcile themselves to this and to be obedient. ${ }^{165}$

With the advance of the Mongols on non-Mongol territories, a system of conquest emerged. As Kirakos Gandzakets'i, Grigor Aknerts'i and other contemporary Armenian sources indicate, Armenian lands were divided by the Mongols into lots during their conquests. This partition can be analysed from several viewpoints: Firstly, it was a part of the Mongols' military tactics, by which they safeguarded not only mobility for themselves, but resisted their opponents' consolidation. Secondly, as the sources indicate, the division was informal. The Armenian lords retained their occupied lands, a fact that allows one to state that Mongol rule in Greater Armenia from 1236 to 1243 resulted in almost no change in the lifestyle of Caucasian Armenians. ${ }^{166}$ The method of land division that occurred in the earlier stages of Mongol expansion may be explained also by the nomadic mindset of the steppe people, in which the concept of maintaining the conquered land and its people had not yet been developed. At this stage, the Mongols sustained supremacy over their conquered lands in a passive way, rather than with direct rule. In our case, the existing indigenous system of Armenian rule was preserved at the local level but was taken under Mongol lordship. ${ }^{167}$ This 'indirect rule' relates to the third point of view, in which the Mongols

${ }^{162}$ For more on Mongol siege machines, see Kennedy, 2002:132-136; Kirpichnikov, 1976.

${ }^{163}$ Liddell Hart, 1927:32.

164 Kirakos Gandzakets'i, 1961:202. For Prester John, see Morgan, 1996:159-170; Jackson, 1997:425-432. For 'King David' or the Ten Lost Tribes of Israel, see Jackson, 2001a:93-105, 2005:143.

165 Ibid., 23.

166 Bedrosian, 1979:116.

167 The category of territorial ruling among the Mongol noyans was applied also in the Chaghatai Khanate and in the Ulus of Jochi /Golden Horde (Koh Byong-ik, 1969:157). 
considered the conquered territories in general as their personal possessions. ${ }^{168}$ Regardless of this notion, the Mongol penetration of Greater Armenia was a 'conquest' and by no means a 'migration' as Bedrosian indicates.

This system of personal territorial possession is particularly illustrated in the case of Greater Armenia before 1256; there was a direct relationship between the Armenian lords and the Mongol noyans. Early Mongol commanders exercised great freedom in acting and making decisions regarding local matters. Each had autonomous power in their respective areas that perfectly served the Armenian lords.

Tracing the names of the Mongol chieftains who conquered Armenia, I found that none of them was from the Chinggisid dynasty or the Borjigid tribe. This fact was taken into account later when Prince Hülegü of the Chinggisid lineage was sent to Iran, and Armenia was incorporated as part of the Il-Khanate.

168 Schurmann, 1956:305. 



\section{STRATEGIC SUBMISSIONS BY THE ARMENIANS}

By examining the establishment of the Mongol protectorate in nonMongol lands, one can see that a conventional set of demands was made for newly-conquered peoples or lands. These demands included the local king's or lord's personal presentation at the Mongol court; the delivery of hostages, usually sons of the nobility; the provision of armed forces; the submission of household registers and payment of taxes; and the provision of stations (yams) for the Mongol governors. The first of these requirements, the personal visits of Armenian lords to the Mongol court represents the most interesting matter along with their policy towards the new reality of the Mongol presence in their lands between 1236 and 1256 and their individual and collective decisions to ally with the Mongols making explicit use of this cooperation. Conflicts that existed among the Armenian princes which led to local revolts against the Mongol regime and the Georgian crown in 1245 and 1259-1261, did not hinder the actual factors to facilitate a Mongol-Armenian alliance.

\section{Individual Submissions and Contacts of Greater Armenian Princes with the Mongol Khans and Il-Khans}

During and after the completion of the Mongol conquest of the Caucasus, some of the Georgio-Armenian princes, recognising the authority of the Mongols, decided to support the Mongol regime and in this way to secure their rights and lands. One of the key decisions of the lords, either on Mongol demand or on a voluntary basis, was to visit the Mongol Great Khans. This factor is identified by Dr. Bedrosian as one of the methods of the 'de-nakhararisation' of Greater Armenia, by which the Mongols aimed in various ways to remove powerful men from the Caucasus. ${ }^{1}$ This statement is debatable, firstly because the process of 'de-nakhararisation' had been

\footnotetext{
${ }^{1}$ Bedrosian, 1979:195.
} 
started before the Mongols' arrival. ${ }^{2}$ Secondly, it only reflects external factors of the process; in my opinion, there was an internal factor as well. Apart from being required by the Mongol overlords, the travels of the Armenian lords to Mongolia also aimed to resolve personal or local matters and the far-reaching result of these journeys was to remove their own potential Georgian or Armenian competitors from the political arena, an aim which perfectly suited Mongol policy.

Awag (d. 1250), the son of Iwanē Zak'arian (d. 1234), was the first Caucasian noble to submit to the Mongols. Kirakos Gandzakets'i gives a detailed account of how this happened. ${ }^{3}$ In 1236, Awag, seeing that the Mongols continued to besiege his stronghold, Kayen, even after taking his daughter and gifts, sent one of Khachen's nobles, Grigor called Tghay to meet the Mongol leader Chormaghan, who was camped at the time by the shores of Lake Geghark'unik' (Sevan). When the great Commander Chormaghan heard about Awag's intention to submit, he ordered his troops to stop besieging the fortress. Soon after, Awag was received by Chormaghan. An interesting conversation between Awag and Chormaghan followed, which can be interpreted from different angles. I am interested in seeing how the interaction between the conqueror and his subject proceeded. The Mongol commander asked Awag why he had not come earlier, when he crossed the borders of his land. Awag replied:

That time you were remote, my father was alive and he served you [the Mongols] in all ways, and since he has died, I will serve you according to my ability, and now, as you have come to my land, here I come to you. ${ }^{4}$

As has been said previously, Awag's father Atabeg Iwanē Zak'arian faced the Mongol advance into Armenia. He fought against Jebe and Sübedei. There is no record in contemporary Armenian sources of the exact relationship between Iwane Zak'arian and the Mongols; however, Awag's answer shows that his father had already given service to the Mongols. Chormaghan told a proverb to Awag: 'I came to the dormer window, you did not come. I came to the door, behold, you have come. ${ }^{5}$ This proverb is associated with a famous Mongolian saying, sükh dalaital üher amrakh (the cow rests until the axe swings),

\footnotetext{
2 Adonts, 1970:183.

${ }^{3}$ Kirakos Gandzakets'i, 1961:254-257.

${ }^{4}$ Ibid., 256. Iwanē Zak'arian died in 1234 (Manandian, 1952:410).

${ }^{5}$ Kirakos Gandzakets'i, 1961:256.
} 
which means 'to rest until real danger comes.' When the Mongol commander ordered a meal in Awag's honour, he sat the latter below all his nobles. Awag was offered a large quantity of meat 'both from clean and unclean animals' and khmuzs (kumis), fermented mare's milk, but Awag said that the Christians were not accustomed to eat such food or to drink such a beverage; they ate meat from permitted animals and drank wine. ${ }^{6}$ Therefore, Chormaghan gave an order to bring what he requested. The next day, Awag was seated above many nobles, and day after day, he was honoured more and more until he sat among the ranks of the great lords. ${ }^{7}$

The plausibility of this conversation is contentious, but surely, Kirakos wants to highlight the pride and bravery of the Armenian prince and the details of his submission. Referring to the customs of the Mongols and Armenians, Kirakos tries to engage with the cultures of both sides and thus to show the diversity of the people coming into contact for the first time. We can assume that the Mongol recognition of Armenian nobility by the Mongols was a very important start in the relationship between conqueror and subject. Perhaps the way Awag was received by the Mongols had a significant influence on the other lords' decision-making.

Indeed, Awag Zak'arian was the first Caucasian lord to exemplify individual submission to the Mongols. This act secured Awag's land. ${ }^{8}$ He obtained a status of invulnerability for all his dominions and established a strong friendship with Chormaghan. In return, Awag was obliged to take his troops with him to march against the city of Ani and to participate in the conquest of the west [Asia Minor]. ${ }^{9}$ After the escape of Queen Rusudan to Swanetia out of fear of the Mongols, Awag became the most influential figure at the Georgian royal court. ${ }^{10} \mathrm{He}$ was de facto ruler of Armenia, and the Mongol administrators sent him to the Great Khan. The exact date of Awag's

${ }^{6}$ Ibid., 256. Friar William of Rubruck gave the same answer to the Mongol host's offer, namely that the Christians do not drink kumis, and that once they had drunk it they would renounce their Christian faith (Rubruck in Komroff, 1989:77). The same answer was given by al-Kāmil Muhammad, the Ayyubid ruler of Mayyāfāriqīn to Mönkge Khan (Jūzjānī, 1970:1266).

${ }^{7}$ Kirakos Gandzakets'i, 1961:254-257.

8 Ibid., 257.

9 Awag participated in Baiju's conquest (Kirakos Gandzakets'i, 1961:280).

${ }^{10}$ Ibid., 238. Queen Rusudan, being under constant pressure from the Mongols, took poison voluntarily and left a will entrusting the kingdom to Awag Zak'arian (Kirakos Gandzakets'i, 1961:316). 
journey to Mongolia is not known, although he paid this visit before the replacement of Chormaghan by Baiju, presumably in 1240/1241. According to Kirakos Gandzakets'i, Awag himself was happy to make this journey so that his visit would help the situation in his country. ${ }^{11}$ In fact, the Great Khan, presumably Ögedei Khan, received the prince with affection, gave him a Mongol wife and sent him home. ${ }^{12}$

It is worth mentioning that the practice of giving vassals a Mongol girl in marriage was exercised extensively by Chinggis Khan and his successors. ${ }^{13}$ However, to my knowledge, there are no records in the Armenian historical annals or church council documents about the regulation of Mongol-Armenian marriages. In view of the fact that the children of such marriages were baptised, one can conclude that these mixed marriages were accepted by the Armenian Church. ${ }^{14}$

After his return from the Mongol court, Awag restored his lordship over his dominion. Nevertheless, in 1245, with increasing anarchy caused by tax collectors, as Kirakos Ganzakets'i testifies, Awag fled to Queen Rusudan, who was still living in a fortress. The Mongols considered this action as rebellion, so Awag wrote a letter to the Khan explaining that his action was not a revolt, but that he was only escaping from disorder. A messenger called Tonghus-aqa came from Güyük Khan to Awag with proof of his immunity. In return, Awag was obliged to convince the Queen to submit voluntarily to the Great Khan. ${ }^{15}$ However, Queen Rusudan died in 1245 before this order came; Awag himself died in $1250 .{ }^{16}$

Awag's submission had a domino effect on the other lords. The Armenian princes, such as Shahnshah (d. 1261), the son of Zak'arē, Vahram Gagets'i (fl. 1240-1250) and his son Aghbugha, and Hasan Jalal, the prince of Khachen, all followed his example in 1236.

On seeing that the other lords retained their lands, the Armenian princes of the Orbelian, Pŕoshian, Dop'ian, Vach'utian and Jalalian houses aimed to cooperate with Mongol administrators in order to retain their principalities, which had been under the suzerainty of

11 Ibid., 262.

12 Ibid., 263.

${ }^{13}$ MNT, 2004:78(\$235), 79(\$238-239).

14 Vasil Tatar, the son of Smbat Sparapet by his Mongol wife, was baptised and knighted in 1265 and was a general-in-chief of the Cilician Armenians (Smbat Sparapet in Der Nerssessian, 1973:373-374).

${ }_{15}$ Kirakos Gandzakets'i, 1961:266.

16 Vardan Arevelts'i, 1991:148; Sebastats'i in Hakobyan, 1956:140. 
the Zak'arids during the previous century. ${ }^{17}$ It was understood that they could regain their own land from the Mongol commanders, as mentioned in the previous chapter concerning a deal between Elikum Orbelian and Aslan Noyan. ${ }^{18}$ This desire of the Armenian lords was welcomed by the Mongols who gave them enchü (injü) status, that of the Khan's personally-owned people, which in Orbelian's History of the Siwnik' Province is interpreted as unknnula (tēruni) or lordly. ${ }^{19}$ Although this status meant that the Mongols imposed some direct obligations on these lords, it did give the latter, who had previously allied with the Georgian King, and their lands some privileges, such as immunity in terms of tax and sovereignty vis-à-vis the Mongols. The outcome of this act brought about the detachment of ties they had formed earlier, for the princes started to alter their attachment to the Georgian King, allying themselves with the Mongols.

This was true as well for Hasan Jalal Dawla (d. 1261) of the Khachen province, the next Armenian noble to support the Mongols. Receiving honour and trust from the Mongols, Hasan Jalal arranged his own affairs in practice. According to the Armenian source, he was the one who supported the Mongol elchis, or messengers, and did whatever was possible for them, whether this meant providing food or horses. ${ }^{20}$ Perhaps because of this, or because he exercised some privileges in arranging his own and Mongol affairs, Amir Arghun (d. 1275/1277), the administrator of Mongol taxation, dis-

${ }^{17}$ Hovsep'ean, 1928:16-17. Iwanē Zak'arian granted the Orbelian house the lands in eastern Vayots' Dzor, in Kotayk', Geghark'unik' and Kayen in 1184 (Step'annos Orbelian, 1910:397). In the 1210s, the Pŕosians or Khaghbakeans helped the Zak'arians in the re-conquest of Vayots' Dzor, Bjni and Dvin (Dwin). As a reward, they were given lands in western Vayots' Dzor, Shahapunik', Varazhnunik' and parts of Kotayk and Ayrarat. The head of the Vach'uteants' family, Vach`ē was a loyal follower of Zak'arē who gave him all the districts of Aragatsotn, Shirak, Nig and Anberd as far as Eraskhadzor. Iwanē's sister Dop'i married Hasan, the prince of Arts'akh in eastern Armenia, receiving a large area on the southern shore of Lake Sevan and the district Sot'k in Siwnik'. They were known as Dop'ians'. Another sister of Iwane married Vakht'ang, the lord of Khachen province; the house took on the name of Jalalians after Hasan Jalal (Babayan, 1976:546-550).

${ }^{18}$ Step'annos Orbelian, 1910:402-403.

19 Ibid., 409; For enchü/injü, see Scherbak, 1997:194; cf. Doerfer, 1963(Vol. 1):220-225. The etymology of enchü is Mongolian emčü, which means a private property (Lessing, 1973:635). Shiraiwa suggests that injül injū is Persianised form of the Mongolian emčü and Rashīd al-Din gave the term three meanings, namely 'personal property,' 'crown land' and 'immediate vassal' (Shiraiwa, 1988:371-376).

${ }^{20}$ Kirakos Gandzakets'i, 1961:269, 284. 
liked him and treated him harshly. ${ }^{21}$ In 1251, in order to escape from Amir Arghun, Hasan Jalal paid a visit to Sartakh (r. 1255-1256) of the Golden Horde. ${ }^{22}$ Sartakh took Hasan Jalal to his father, Batu Khan (r. 1205-1255), who returned to Hasan Jalal his patrimony of Ch'araberd, Akanay and Karkaŕn, which previously the Seljuks and the Georgians had taken from him. ${ }^{23}$ Using his close relationship with Sartakh, he succeeded in separating Khachen from Georgia and the Zak'arid Princes, as reflected in his title. Armenian inscriptions of Mama-Khatun, the daughter of Hasan, in Gandzasar, dated 1280 and 1286, mention his name as 'Prince of Princes, the Lord of Khachen.' In the inscription of Amaghu-Noravank', dated 1292, Mina-Khatun, the other daughter of Hasan, refers to her father as 'Great King.'24

In 1255, when Sartakh went to visit Möngke the Great Khan, Hasan Jalal joined him with his family, as is mentioned in the colophons of a Gospel in $1261 .{ }^{25} \mathrm{He}$ was granted enchü status by Möngke Khan in 1255. In return, he was obliged to perform military service every year. ${ }^{26}$ His position was secured by the marriage of his daughter to Bora Noyan, the son of Chormaghan. ${ }^{27}$ However, his daughter's marriage could not guarantee his life. In 1261, because of his failure to pay tax to the Mongols, and mainly because he had lost the protection of Sartakh who died in 1256, Hasan Jalal was tortured and killed by Amir Arghun in Qazvin. ${ }^{28}$

Another prince to whom Möngke Khan granted enchü status was Smbat Orbelian of the Siwnik' province, who visited Qara-Qorum in $1251 / 1252$. He went there to secure his land from Gontsa, the wife of the late Awag, who had infringed on his territory. In the narration

21 Ibid., 373.

${ }^{22}$ Kirakos Gandzakets'i, 1961:358. This was a master stroke of Hasan Jalal, to use the conflict between two Mongol powers in Iran and Russia. The Caucasus became an occasional arena of conflicts between the Il-Khanate and the Golden Horde from 1261 until 1266.

${ }^{23}$ Ibid., 1961:359.

${ }^{24}$ Orbeli, 1963:158; CIA, 1982:80.

25 Mathevosyan, note 258, pp. 311-312; Orbeli, 1963:155-156, 163 (note 26).

${ }^{26}$ Kirakos Gandzakets'i, 1961:269. Hasan Jalal had already participated with Baiju in the battle of Ch'man-katuk (Köse Dagh) between the Seljuks of Rüm and the Mongols in 1243 (Kirakos Gandzakets'i, 1961:283-284).

${ }^{27}$ Kirakos Gandzakets'i, 1961:391.

${ }^{28}$ Vardan Arevelts'i, 1991:152. Hasan Jalal's son At'abek brought his father's body to be buried in Jalal's ancestral cemetery at Gandzasar monastery (Kirakos Gandzakets'i, 1961:390-391). 
of his journey written by Step'annos Orbelian, Smbat, in return for a valuable precious stone (a ruby) presented to the Great Khan, retained the lands of Vorotan up to the boundaries of Borotna and Bghen, within which the Siwnik' court of Tat'ew was located. Besides this, he received Eghegis with the district of Vayots' Dzor; P'oghahanos; Urts, Vēdi with the valley of Ererawn, and many villages in Kotaik and Geghark'uni. ${ }^{29}$

Just before the vital shift of Mongol power from Baiju to Hülegü in Greater Armenia, Smbat Orbelian secured sovereignty over his dominions from the Zak'arid suzerains and the Georgian king by his second journey to Möngke Khan in $1256 .{ }^{30}$ The independence of the Orbelian prince was reflected in his title as 'King Smbat' in the inscription in Noravank in $1275 .{ }^{31}$ Smbat remained an important vassal of the Mongols in the time of the Il-Khans. He was sent by Hülegü Khan (r. 1256-1265), the first Mongol Il-Khan, to Ala Taq (Daŕn Dasht) to assist the latter in building a large royal palace. ${ }^{32}$

Having support from Hülegü Khan to implement his political goals, Smbat Orbelian encountered a serious opponent, Sadun Artsruni /Mankaberdeli (d. 1284), the atabeg and army commander of Awag. Seeing that Smbat possessed strong ambition, Sadun Artsruni decided to support Gontsa, the wife of the late Awag, who later married the Georgian King David (r. 1259-1270). ${ }^{33}$ While Smbat was in Qara-Qorum, Sadun replaced him as the guardian of Khoshak, ${ }^{34}$ the daughter of Awag and Gontsa, according to an anonymous Georgian source of the thirteenth century, and he was consequently recognised by the Georgian Court. ${ }^{35}$ Thus, Sadun became an influential figure in the political arena. Later, he was also recognised and honoured by Hülegü when he defeated the most valiant Mongol wrestler. ${ }^{36}$ The wrestling match at the Mongol Court was perhaps equivalent to the Christian knights' jousting tournaments. Being a successful wrestler in the ring meant being a good warrior in the field. Therefore, according to Grigor's perception, Sadun's victory

${ }^{29}$ Step'annos Orbelian, 1910:411.

${ }^{30}$ Ibid., 414.

${ }^{31}$ Kostaneants', 1913:118; Grigoryan, 1990:72, 75.

${ }^{32}$ Step'annos Orbelian, 1910:415.

${ }^{33}$ Melikset-bek, 1936:58.

34 The names of Khoshak and Sadun, the atabeg, are found in the inscription of the church of the Mother of God in Noratus (Avagyan, 1978:277).

${ }^{35}$ Melikset-bek, 1936:58.

${ }^{36}$ Grigor Aknerts'i, 1974:49. 
impressed the Mongols. This may serve as another example of an Armenian historian's insights into the development of MongolArmenian relations, as well as may illustrate Armenian lords' internal rivalry.

When Abaqa Khan (r. 1265-1282) succeeded to the Il-Khanid throne, Sadun befriended Shams al-Dīn Juvaynī, the șāhib-dīvān (executed in 1284), whom Khoshak, Sadun's protégée, married in $1269 .{ }^{37}$ After Hülegü's death, Smbat Orbelian lost his influential role in the political life of Armenia and Sadun became the favourite of Abaqa Khan. Moreover, he strengthened his position as atabeg of Georgia. ${ }^{38}$ The cities of Kars, Telavi and Bailaqan were separated from royal Georgian control and given to Sadun Artsruni. ${ }^{39}$

In order to re-establish the Orbelian House's authority, a brother of Smbat, Tarsaich, showed his loyalty to Abaqa Khan by participating many times in his battles. ${ }^{40}$ On becoming regent in 1270, Tarsaich enthroned young King Demetrē II (r. 1270-1289) on the Georgian throne. ${ }^{41}$ Tarsaich was welcomed by Arghun Khan, who gave Demetrē all the territories of the Zak'arids, Gagets'i and Sadunians (Artsrunids).$^{42}$ Demetrē also appointed Tarsaich as atabeg of the Georgian lands. ${ }^{43}$

As can be seen, the above examples are cases of individual submission and of negotiations to ally with the Mongol Empire. Individual contacts between Armenian lords and either the Mongol Khan or his representatives during the early period of the Mongol presence secured Greater Armenia from major Mongol repression. Later, obtaining support from the Il-Khans, the Armenian lords once again secured authority over their Houses and lands.

\footnotetext{
${ }^{37}$ Step'annos Orbelian, 1910:418. Khoshak and Shams al-Dīn Juvaynī had a daughter Khuandze and a son Zak'arē (Rashīd al-Dīn, 1946:115-116; Melikset-bek, 1936:60; Babayan, 1969:175).

${ }^{38}$ Melikset-bek, 1936:60.

${ }^{39}$ Ibid., 60.

40 Step'annos Orbelian, 1910:423. The first wife of Tarsaich, Aruz Khatun, was

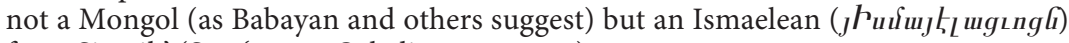
from Siwnik' (Step'annos Orbelian, 1910:416).

${ }^{41}$ Ibid., 426.

42 Ibid., 426.

${ }^{43}$ Ibid., 426.
} 


\section{State Submission and Its Development: The Armenian Kingdom of Cilicia}

If the princes of Greater Armenia dealt with the Mongols through their individual submissions to the Mongol Empire, the king of the Armenian Kingdom in Cilicia followed a different paradigm. The Armenian Kingdom in Cilicia held a unique historical position among the Christian states of the Levant, with its ties to the kingdom of Cyprus and principality of Antioch, and its very tense diplomatic relations with the Papacy. The attempt by Rome to force the Armenian Church to adopt Catholicism ${ }^{44}$ together with the direct threat from Egypt, made King Het'um I await the outcome of the battle in Köse Dagh or Ch'man-katuk (2uul-Guunnzl) with great interest. Once it was clear that the Sultanate of Rum had become a vassal of the Mongols, the Armenian Kingdom in Cilicia chose to begin negotiations with the Mongols prior to their advance on Cilician lands. In 1243, King Het'um sent his brother Smbat Sparapet, the Armenian commander from 1226 to 1276, along with his father, Baron Kostandin, to Baiju to propose their 'obedience. ${ }^{35}$ Baiju, who was advancing on Western Asia Minor, demanded that Cilician Armenia deliver to him the mother, wife and daughter of the Seljuk Sultan. ${ }^{46}$ For an account of this, we have the Chronicle of Smbat Sparapet, which states the details of the negotiations ${ }^{47}$ Fearing that the Mongols would progress onto his land, Het'um decided to hand over the Sultan's relatives. For its assistance to Outremer, Cilician Armenia was constantly under pressure from the Seljuks. The Syriac source of Bar Hebraeus reacts to this incident critically, saying: 'This most hateful and blameworthy act appeared in the sight of all kings as a thing which should never have been done. ${ }^{38}$ This act was the reason

${ }^{44}$ Bundy, 1987:227; Der Nersessian, 1947:15.

${ }^{45}$ Kirakos Gandzakets'i, 1961:285; Smbat Sparapet, 1868:649; Bar Hebraeus, 1932(II):408; Davit‘ Baghishets'i, 1956:346.

${ }^{46}$ Kay-Khusraw II, whose wife and daughter had sought refuge at the Armenian court at the time of the Mongol attack on Konya (Iconium) (cf. Cahen, 1969:138).

${ }^{47}$ When the talks began, the Mongols threatened Het'um's delegation with an ultimatum: Either the refugees of the Sultan should be handed over or the Mongols would devastate their country (Smbat Sparapet, 1868:649). Bar Hebraeus records this act differently, stating that Baron Kostandin (Constantine), the father of King Het'um, himself revealed the secret whereabouts of the Sultan's relatives to please the Mongols (Bar Hebraeus, 1932[II]:408).

48 Bar Hebraeus, 1932(II):408. Modern scholars discuss this act as well. Some accuse Het'um of breaching the code of eastern hospitality by surrendering his guests to Baiju (Gordlevskii, 1941:36-37). 
that some Armenian nobles rebelled against Het'um, joining the Seljuks and occupying a few Armenian fortresses. ${ }^{49}$ However, Het'um was determined to submit to the Mongols and, by handing over the Sultan's family and turning the Sultanate of Rūm into his irreconcilable enemy, he gained Mongol confidence. Het'um's foreign policy towards the Mongols started in Caesarea and paved the way for securing the survival of the Armenian kingdom in Cilicia. He reached an agreement whereby Cilician Armenia recognised its dependence on the Mongol Empire and was obliged to supply forces and provisions when necessary, and also to send a delegation to the Mongol court. The Mongol commander, in turn, promised to provide military protection against attacks by Muslim neighbours. ${ }^{50}$

According to this agreement, as Armenian sources claim, Baiju sent Smbat Sparapet to the Great Khan Güyük. ${ }^{51}$ Smbat Sparapet and his father Kostandin left Cilicia in 1246 for the Mongol court at Qara-Qorum, where Smbat, as the ambassador of the Armenian king, on his behalf made his submission to Güyük. ${ }^{52}$ The following story narrated in detail by Grigor Aknerts'i is an example of the Armenian historian's intention to explore the cause and the process of these events:

The pious and Christ-crowned king of Armenia, Het'um, with his father endowed with all wisdom, and [with his] God-fearing brothers and princes, entered council, and decided in their own minds to become subject to the Tatars and to pay taxes and xalan, ${ }^{53}$ and not allow [the Mongols] to enter their own God-created and Christian country, and so it happened. After they first saw Baiju, the commander of the Tatars, they confirmed treaties of love and submission. Then after that, they sent the brother of the King, the sparapet of Armenia, Baron Smbat to Sayin Ghan [Great Khan Güyük], who was seated on the throne of Chinggis Khan, and he went with God's blessing to see Sayin Ghan, because this Ghan was pious and very fond of Christians. ${ }^{54}$

49 Boase, 1978:25. The Armenian noble, Constantine of Lambron, sought to revolt against King Het'um and appealed to Kay-Khusraw. After the affirmation of Mongol protection over Cilician Armenia, Constantine took refuge with his Turkish friends (Cahen, 1968:270-271).

${ }^{50}$ Grigor Aknerts'i, 1974:31-32; Galstyan, 1976:31.

${ }^{51}$ Grigor Aknerts'i, 1974:31.

52 Smbat Sparapet in Galstyan, 1962:48; Davit' Baghishets ‘i, 1956:346.

${ }^{53}$ For xalan or qalan, a tax imposed on military service or on land use, see Chapter 4.

${ }^{54}$ Güyük had strong leanings towards Christianity, though he actually remained a Shamanist. 
Because of this, his race called him Sayin Ghan, which in their language means 'good Ghan.'

Sayin Ghan, seeing the Sparapet of Armenia, rejoiced very much because of his Christian faith, and even more because of the skilful and wise words, which the Sparapet of Armenia, Smbat spoke before him. And he [Sayin Ghan] made him a subject prince, and gave him a big yarlax $^{55}$ and golden p $^{6}$ ayzays ${ }^{56}$ and a Tatar xatun [wife], ${ }^{57}$ and this was for them [the Mongols] an expression of great love; whomsoever they [the Mongols] loved and respected, they gave in marriage a wife from among their honoured women. Thus, having bestowed great honour on the Armenian Sparapet, they sent him to his lands, to see Het'um, the Christian king of Armenia, ordering him [Het'um] to go himself and see him [Great Khan]. The pious King Het'um, seeing that Baron Smbat, his brother, was favoured with such honour and respected by the Ghan, rejoiced greatly, even more for having obtained documents freeing [from taxation] the country and monasteries and all Christians. ${ }^{58}$

There is an opinion that Smbat Sparapet did not reach Güyük Khan or the Mongol Court and that he only journeyed to Batu Khan of the Golden Horde. ${ }^{59}$ The reason for such an assumption is that the name Sayin Khan was usually associated with Batu Khan, grandson of Chinggis Khan. ${ }^{60}$ Therefore, it is concluded that Smbat Sparapet visited Batu Khan, since after Güyük's death, Batu Khan (r. 12271255), according to seniority among the Chinggisids, was in charge of all affairs until the enthronement of Möngke Khan. ${ }^{61}$ It is hard to agree with this view because the association between Sayin and Batu Khan does not mean that the other Khans could not be referred to as 'good' or Sayin, as was the case with Güyük Khan. ${ }^{62}$ From the cited episode, it is clear that Smbat Sparapet undertook his journey in 1246 , so it is very likely that he reached Mongolia before Güyük Khan's death in $1248 .{ }^{63}$ Secondly, the act of submission, which was

\footnotetext{
${ }^{55}$ Yarligh (Jarlig), a decree and a patent guaranteeing immunity ( $c f$. Doerfer, 1963(Vol. 4):153.

${ }^{56}$ Paiza, a metal tablet that served as a passport guaranteeing safe passage ( $c f$. Doerfer, 1963(Vol. 1):239.

57 By this Mongol wife, Smbat had a son called Vasil Tatar (Smbat Sparapet in Der Nerssessian, 1973:373, 374; Galstyan, 1958:xi).

${ }^{58}$ Grigor Aknerts'i, 1974:31-32; cf. R. Blake and R. Frye’s translation, 1954:313, 315.

59 Manandian, 1952:220.

${ }^{60}$ Grekov and Yakubovsky, 1937:103.

${ }^{61}$ Manandian, 1952:220.

${ }^{62}$ Cf. Cleaves, 1954:425.

${ }^{63}$ On foreign delegation at Mongol court in 1248, see Bar Hebraeus, 1932(Vol. 2):320-322; Carpini in Komroff, 1989:40-44.
} 
accompanied by the grants of yarligh and paiza, indicates a royal reception. ${ }^{64}$ Moreover, the giving of a Mongol woman in marriage and thus the creation of a vassal as son-in-law is more a royal gesture than that of a ruler of one of the Uluses, as was seen in the case of Awag Zak'arian. ${ }^{65}$ Chinggis Khan exercised this practice widely among his subordinates and subjects and thus pursued his diplomacy. ${ }^{66}$

Furthermore, a brief account of Smbat's journey to Mongolia can be found in a letter from Smbat to his brother-in-law, Henry I Lusignan of Cyprus, written in 1248 at Samarkand. ${ }^{67}$ According to Galstyan, this document is attributed to Smbat because the term Constable is used in the text for the sender of this message. It is known that, between 1226 and 1276, only Smbat Sparapet held the office of Gundstable (Armenian version of Constable) in the Armenian Kingdom of Cilicia. This letter is important for the detailed description of the places Smbat passed through during his journey to the Mongol court, which took him more than eight months in each direction. The letter also mentions political conditions in Mongolia, stressing that there had been several years of interregnum after the death of the present Khan's father (Great Khan Ögödei [r. 12291241]). ${ }^{68}$ Smbat says that since the Mongol princes were dispersed all over the kingdom, it took five years for them to gather and to crown the successor (Güyük Khan). ${ }^{69}$ In his letter, Smbat also points out a chapel built in front of the Great Khan's court, which allegedly

${ }^{64}$ There were cases when Mongol governors or residing princes granted paiza or yarligh to their vassals; however, the privileges they granted were more of economic concern, like taxation or compulsory labour. Thus, Sartakh granted these privileges to Hasan Jalal and to Nersēs, the kat'oghikos of the Caucasian Albanians, as well as to churches and mosques (Kirakos Gandzakets'i, 1962:358). Later, these unsanctioned acts by princes were abandoned by the central court by sending Amir Arghun to the region to bring order to the peripheries of the Mongol Empire (Juvaynī/Boyle, 1997:507). Hülegü was also dispatched to put an end to the provisional regime of the Mongol military rule and fiscal administration in the region (Rashīd al-Dinn, 1946:23).

${ }_{65}$ Although Prince Hủlegủ gave a Mongol wife to the Ismāîlī Imam Rukn al-Dīn Khur-Shāh, Hülegü sent the latter to the Mongol court in Mongolia for approval (Juvaynī/Boyle, 1997:721-722).

${ }^{66}$ MNT, 2004:78, 79, $84(\$ 235,238,248)$.

${ }^{67}$ Jackson, 2005a:98. Galstyan suggests that the letter was written in 1247 (Galstyan, 1962:64, 122-123 [note 155]).

${ }_{68}$ A Russian translation of Smbat Sparapet's letter to King Henry I Lusignan of Cyprus is found in Galstyan, 1962:64-66.

${ }_{69}$ Ibid., 66. 
indicates that the Khan and his people had become Christians. ${ }^{70}$ The most interesting part is the ending of his letter. He tells Henry that the Pope had sent his mission to the Khan inquiring whether he was Christian, at which the Khan told him that God knew it, and if the Pope wished to know, he should come and find out for himself. ${ }^{71}$

From this letter, we conclude that Smbat visited Qara-Qorum in 1248. Smbat's contemporary, Bar Hebraeus, in his Chronography clearly states that the Sultan of Rūm, Rukn al-Dīn, the Constable of Cilician Armenia, the Georgian crown princes, the senior and junior Davids and many other ambassadors from Asia and Europe went to Great Khan Güyük. ${ }^{72}$ Indeed, Smbat could possibly have met those who were in Mongolia after Güyük's coronation ceremony, such as the Papal ambassador Friar Plano Carpini, ${ }^{73}$ the Alamut delegation of Shihāb al-Dīn and Shams al-Dīn, ${ }^{74}$ the officials of Cathay (Northern China) and Korea, as well as amirs of Transoxiana, Khurasan, Iraq, Lur, Azerbaijan, Shirvan, the Sultanate of Rūm, and Georgia. Besides these, there were the Russian ambassador, Prince Yaroslav of Suzdal, the ambassadors of Aleppo, Mosul and Baghdad. ${ }^{75}$ They all had different purposes in visiting Qara-Qorum. Thus, in delivering the Pope's letter to Güyük Khan, Plano Carpini had three goals: First, to convert the Mongol Khan to Christianity, second to establish an alliance of friendship, and third, to assess the real threat to Europe posed by the Mongol Empire. ${ }^{76}$

The Cilician delegation came to the Great Khan to make a vow of peace and to become a subordinate state. They were well received

${ }^{70}$ Ibid., 66. This letter was presented to King Louis IX (1226-1270) on his arrival in Cyprus with the Seventh Crusade in 1248, who found it important enough to be forwarded to Pope Innocent IV (1243-1254) (Jackson, 2005a:98).

${ }^{71}$ Galstyan, 1962:66; Jackson, 2005a:98.

72 Bar Hebraeus, 1932(Vol. 2):320-321.

73 The Franciscan Plano Carpini left Lyons in April 1245. After travelling for fifteen months across Russia and the steppes of Central Asia, he reached the Imperial camp near Qara-Qorum in August 1246 to witness the Quriltai that elected Güyük to supreme power (Carpini in Komroff, 1989:40-41).

${ }^{74}$ Daftary, 1998:150.

${ }^{75}$ Carpini in Komroff, 1989:41.

76 The Great Khan Güyük, who had many Nestorian Christians among his advisers, received the Papal envoy kindly. However, after he read Pope Innocent IV's letter, requiring him to accept Christianity (the Latin text in Lupprian, 1981:179-181), he wrote a reply ordering the Pope to acknowledge his suzerainty and to come with all princes of the West to do him homage. This letter dated November 1246, written in Qara-Qorum in Persian, still exists in the Vatican archives (the Latin version in Lupprian, 1981:182-189) (Pelliot, 1923:3-30, 1924:225-335). 
and after a four-year journey, which also confirms that their journey was not to Batu Khan of the Golden Horde, they returned to the Armenian capital at Sis in $1250 .{ }^{77}$ Unfortunately, the Chronicle of Smbat Sparapet, despite being one of the most important Armenian sources for the history of Cilician Armenia, the Crusades and the Mongols, contains little information about his visit to Mongolia. ${ }^{78}$ It states only that 'in 697 [Arm.] (1248) I, Smbat Gundstable, went to the Tatars, and in 699 [Arm.] (1250), I returned to my brother, King Het'um. ${ }^{79}$ Galstyan agrees that it is obvious that the date of 1248 for Smbat's journey to Mongolia is a scribal error. ${ }^{80}$ This could well have been the date of his arrival in Qara-Qorum.

The success of the Cilician Armenian delegation in negotiating with the Mongols is a matter of interest. Through their intelligence network, the Mongols came to know well the internal and external preoccupations of the region. ${ }^{81}$ They knew that Cilician Armenia was a small Christian state that was in conflict with surrounding hostile Muslim sultanates and that the Armenians needed an alliance with those who were more powerful. On the other hand, the Sultanate of Rūm was still 'a stumbling block'on the way to the Mongol expansion beyond the borders of their empire, and having a loyal vassal state to rely on would be an advantage for the Mongols. This situation assured the success of the first stage of Mongol-Armenian negotiations.

The Great Khan sealed a memorandum with the Cilician delegates, ensuring that no-one would oppress the Armenian princes and that they might rule their kingdom without fear. However, there was one demand: King Het'um was requested to visit the Mongol Court personally. ${ }^{82}$ Therefore, following this 'invitation,' Het'um I visited the

77 Het'um Patmich', 1951:44.

78 Smbat's Chronicle is known as the Royal Chronicle or Cilician Chronicle (Der Nersessian, 1973:365).

${ }^{79}$ Smbat Sparapet, 1869:651. Armenian tradition says that Smbat was a wise Armenian Sparapet or Gundstable [Constable] (Grigor Aknerts'i, 1974:31-32).

${ }^{80}$ Galstyan, 1962:121(note 139). The discrepancy in dates between different editions of the Chronicle is studied in Der Nersessian, 1973. A manuscript of Smbat's Chronicle, dated 1315 and published in 1956 in Venice is used by Galstyan, 1962. The manuscript quoted in this study (no. 1308, the Library of San Lazaro) is less informative. There are several lacunae in this manuscript and many parts are missing (cf. Der Nersessian, 1973:353).

${ }^{81}$ Cahen, 1968:273.

${ }^{82}$ Kirakos Gandzakets'i, 1961:366-367; Grigor Aknerts'i, 1974:31-32; Davit Baghishets'i, 1956:346; Galstyan, 1976:31. 
court of the Mongol Khan in Qara-Qorum, making a journey of 3,500 miles in $1253 / 1254 .^{83}$ Qara-Qorum at that time was not only the capital of the Mongol Empire, but also a centre of diverse cultures and religions. It was the destination for ambassadors, travellers, missionaries and merchants. As has been said above, there were representatives of the Caliph, the Seljuk Sultan, diplomats from the Byzantine court and from other parts of the world. ${ }^{84}$ This was where the Armenian king had his meeting and dialogue with the Great Khan.

Many contemporary Armenian authors document this historical episode. Grigor Aknerts'i states that King Het'um went to Mongolia because of his love for the Christians and even more because of his concern for his own land. ${ }^{85}$ Vardan Arevelts'i confirms that He'tum made a victorious trip to Mongolia. ${ }^{86}$ Kirakos Gandzakets'i records the journey of King Het'um to Qara-Qorum with emphasis given to the historical geography of Central Asia along with zoology, mineralogy, aspects of Buddhism, folklore and tales. ${ }^{87} \mathrm{He}$ gives a list of sixteen localities through which Het'um passed, some of which are recorded only in his history. ${ }^{88} \mathrm{Het}$ 'um Patmich', the historian known as Hayton, provides extensive references to King Het'um's journey. ${ }^{89}$ Modern scholars have examined the routes of the journeys taken by King Het' 'um and other travellers of that period, such as Carpini and Rubruck. ${ }^{90}$ Attempts have been made to reconstruct the routes of these travellers. According to Boyle, the itinerary of the Armenian king through Uighur country along the right bank of the Syr Darya (Sïr-Daryā) seems to have been the normal highway for the medieval travellers. ${ }^{91}$

${ }^{83}$ Smbat Sparapet in Galstyan, 1962:49; Chahin, 1987:284. The journey of Het'um began at Sis and was sanctioned first by Baiju Noyan in Kars, who dispatched him to the gate of Derbent to Batu and Sartakh of the Golden Horde, who sent him to Mongolia (Kirakos Gandzakets'i, 1961:366-367). This relay dispatch of visitors via Baiju and then Batu Khan was implemented for the lords of Greater Armenia (Awag, Hasan Jalal and others) as well.

${ }^{84}$ Rubruck in Komroff, 1989:187.

${ }^{85}$ Grigor Aknerts'i, 1974:37.

${ }^{86}$ Vardan Arevelts'i, 1991:149.

${ }^{87}$ Kirakos Gandzakets'i, 1961:364-372.

${ }^{88}$ Gandzakets'i, 1961:366-372.

89 The History of the T'at'ars (1307) by Het'um Patmich' is also a remarkable ethnographic and geographical account (Bundy, 1987:223-235).

90 Bretscheider, 1887:164-172; Boyle, 1964:175-189.

${ }^{91}$ Boyle, 1964:177. 
The Mongol Great Khan Möngke received King Het'um (r. 12261270)..$^{92}$ According to Smbat Sparapet, the Mongol Khan in this reception 'fulfilled all requests of the Armenian King. ${ }^{.93}$ Kirakos makes a very clear point about this visit, stating that King Het'um remained in Möngke Khan's ordu for 50 days and the Mongol Khan gave the Armenian king a noteworthy edict (hpnyupunuly Ezuinuinp) that 'no one should harass him or his country.' Moreover, he indicates that Möngke Khan gave him a document ( $q \mathrm{hp}$ ) proclaiming freedom for the Church everywhere. ${ }^{94}$ Based on what these sources refer to, it is clear that the Cilician king made his submission to the Mongols.

However, it is interesting to find out what was requested by the King and what kind of document was given to him. If we assume that the 'edict' mentioned by Kirakos was a yarlikh (surely not a paiza, a metal tablet of authority), then what stands for document $(q h p)$ that was given to the Armenian king? Unfortunately, the contemporary Armenian sources do not solve this problem. The only source that highlights this issue is the early fourteenth century work of Het'um Patmich', known as Hayton.

In order to establish the degree of the plausibility for this source, it is worth taking an overview of related issues addressed in this work.

According to Het'um Patmich', Möngke Khan welcomed the Armenian king graciously on account of his voluntary submission and his desire to establish peace and an alliance with the Mongol rulers. ${ }^{95}$ The following is an extract from Het'um Patmich's history on the agreement sealed by both parties. It is said that the Armenian king put the following seven points to the Mongol Khan to be agreed: ${ }^{96}$

${ }_{92}$ Möngke, the eldest son of Tolui, was elected as the fourth Khan of Mongolia at the quriltai of 1251 . He decided to complete and consolidate the Mongol conquest of China and Western Asia respectively and to control matters directly in Iran and the Caucasus (Shirendyb, 1966:125-126). According to Het'um Patmich', the Armenian King Het'um was received in Almalik (Ameghek) by Möngke, not in QaraQorum (Het'um Patmich', 1951:45).

${ }_{93}$ Smbat Sparapet in Galstyan, 1962:49.

94 Kirakos Gandzakets'i, 1961:367.

${ }_{95}$ The partial translation of the source into Russian by Galstyan in 1962, is related to the agreement of Möngke Khan and King Het'um and based on the French original and the Latin version (Bundy, 1987:223-235).

${ }_{96}$ Het'um Patmich', 1951:45. This translation is by the author of this study from the Armenian version edited by Awgerean (cf. Galstyan, 1962:68). 
1. To be converted to Christianity and to be baptised; ${ }^{97}$

2. To establish peace and friendship between them; ${ }^{98}$

3. In all Tatar lands to establish Christian churches and to let the Armenians be free from any taxes and other oppressions; ${ }^{99}$

4. To take from the hands of the Turks the Holy Land and holy tomb and to give them to the Christians; ${ }^{100}$

5. To suppress the Caliph of Baghdad, who was the chief of a sect;

6. All Tatars to help them in time of need;

7. Every province of the lands of the Armenians, where the Turks ruled, to be given back. ${ }^{101}$

Some scholars see the purpose of this work and this agreement itself, especially the two clauses relating to the baptism of Möngke Khan and to the liberation of the Holy Land and its restoration to Christian possession, as sheer fantasy on the part of Het'um Patmich' who desired to 'set Western-Mongol relations on a new footing. ${ }^{102}$ This claim is based on the fact that such an agreement is not found in other contemporary sources, including the sources written by Armenian authors, like Kirakos Gandzakets'i. ${ }^{103}$ However, as has been said above, Kirakos clearly referred to the visit and to a document being issued.

We can see that the existence of Het'um's document cannot be proved. However, the whole nature of the agreement brought into consideration by Het'um Patmich' may serve as an illustration of the development of Mongol-Armenian relations and it commands attention. Even if the terms of the agreement are wishful thinking on the part of Het'um Patmich', it remains interesting to know what his ideal objectives were. Since these objectives were in fact consistent with the actual course of the relationship between the Cilician Armenians and the Mongols in their early stages and whether these

\footnotetext{
${ }^{97}$ Friar William Rubruck met an Armenian monk called Sergius [Sargis] in Qara-Qorum, who was going to baptise Möngke Khan on the Feast of the Epiphany in 1254 (Rubruck in Komroff, 1989:138).

${ }_{98}$ The Russian translation of Galstyan gives us more details. The second point is translated as 'peace and friendship between Christians and Tatars' (Galstyan, 1962:68).

${ }^{99}$ This point has been translated 'In all land occupied by Tatars or those that will be captured later' in Galstyan, 1962:68.

100 Saracens instead of Turks (Galstyan, 1962:68).

101 'All lands dependant on the Armenian Kingdom and those captured by the Saracens and those under the Tatar's supremacy to be retained' in Galstyan, 1962:68.

102 Jackson, 1980:486.

103 Ibid., 486.
} 
individual clauses existed or not, they can serve as an explanation of the relationship in the long term.

To confirm his account of events, the Armenian author gives details of the Mongol Khan's reaction to the Armenian King's offer. According to Het'um Patmich', Möngke Khan requested clarification of the clause (no. 6) that related to Mongol help when needed. Presumably, King Het'um I could not predict exactly when he would need Mongol help but obviously Het'um's aim was not merely to preserve his own kingdom and to obtain protection for the Christians under Mongol rule, but to enlist the Khan's help in freeing the Holy Land from the Muslims. ${ }^{104}$ If we follow Het'um Patmich', he says that the assurance given by Möngke's predecessor Güyük Khan was renewed and expanded. This implies that earlier, there was a certain agreement, possibly a memorandum, written or oral between Güyük Khan and Smbat Sparapet. Although almost nothing is known about the Mongol conditions, according to Het'um Patmich', Möngke promised to liberate the Holy Land, delegating these duties to his brother Hülegü, to whom Batu and other Mongol noyans stationed in Russia and Rūm should give assistance. Moreover, the Great Khan agreed to free Armenian churches and monasteries from taxation in territory under Mongol supremacy. ${ }^{105}$ In return, one can assume that the Mongols required from the Armenians all that they asked from their other vassals and allies: Obedience, tributes and support with provision and soldiers.

Mikaelean is possibly the first scholar to argue for the existence of such a document. He gives importance to the wider spectrum of this agreement, i.e., the issues of peace between the Christians and Mongols proposed by the Armenian King. ${ }^{106}$ Galstyan confirms that Het'um Patmich' used the sources that were available to him through his uncle, Smbat Sparapet, who led the first Armenian delegation to the Mongol court. He makes extensive references to this document in his Russian translation based on the French and Latin texts. ${ }^{107}$ In addition to this, it is worth noting that the baptism of Möngke Khan was not just in the mind of Het'um Patmich'. Rubruck mentioned that there was an attempt to baptise Möngke Khan in Qara-Qorum,

\footnotetext{
104 Het'um Patmich', 1951:45-46.

105 RHC/DA, 1869(Vol. II):297; Kirakos Gandzakets'i, 1961:367.

106 Mikaelean, 1952:310-314.

107 Galstyan, 1962:124-126 (note 164).
} 
in 1254, when he met the Armenian monk Sergius [Sargis]. ${ }^{108}$ We can therefore suppose that Het'um Patmich' was following the course of historical events and reflecting the common beliefs or ideas of the time. His aim was to provide evidence for the terms of the agreement being carried out and thus to confirm the submission of the Armenian monarch to the Mongols.

King Het'um returned home in 1256, encouraged by Mongol promises. On his way out and back, he passed through Greater Armenia, where many local princes and ecclesiastics welcomed him. ${ }^{109}$ It was the first time that a ruler of Cilicia had come into direct contact with the mother country. ${ }^{110}$ On his return, in October 1256, Het'um immediately exercised Mongol backing over the territories of the Sultanate of Rūm, near the city of Arakly. He went there with an army of up to 100,000 people, including all his relatives with their azats (nobles) in revenge for the devastation of the fortress and church of Murand by the Seljuks. ${ }^{111}$ Evidently, the Seljuks were no longer seen as a threat by the Cilician Armenians after the latter concluded their alliance with the Mongols. ${ }^{12}$

King Het'um tried to win the Latin princes over to the idea of a Christian-Mongol alliance but could convince only Bohemond VI of Antioch, who to some degree was Het'um's vassal through his marriage to his daughter Sybille. ${ }^{113}$ Despite the refusal of the Latin Christian states to follow Het'um's example and adapt to changing conditions by allying themselves with the new Mongol Empire, the Mongol-Cilician Armenian alliance was established and was beneficial as long as the Mongols stayed in power in the nearby region.

${ }^{108}$ Rubruck in Komroff, 1989:138-146.

${ }^{109}$ His visit to Mongolia was appreciated in Greater Armenia. On his way to Mongolia, King Het'um stopped in the village of Vardenis (Vayots' Dzor) with his host Prince Pŕosh Khaghbakian (Babayan, 1976:618).

${ }^{110}$ Der Nersessian, 1962:653.

111 Smbat Sparapet in Galstyan, 1962:49-50. An army of 100,000 seems to be exaggerated. The largest joint Mongol-Armenian forces did not exceed 60,000. The joint Armeno-Georgian forces that participated in the Mongol campaigns in Syria did not exceed 30,000 men (see Chapter 7).

${ }_{112}$ Mikaelean, 1952:326.

113 Boase, 1978:25; Der Nersessian, 1969:49. 
While Het'um was gaining some results from his cooperation with the Mongols and regaining some fortresses that had been taken from him by the Seljuks, the antipathies that existed between and within the noble families in Greater Armenia came to a climax. This situation, which was extremely common in all subjugated lands, suited the Mongols' policy, since they were seeking loyal vassals on the one hand and aimed to disrupt the unity of the Armenian lords on the other. Thus, to punish Awag Zak'arian for his escape, his land was given to his cousin Shahnshah. ${ }^{114}$ By incorporating certain lords into their own court and administration, the Mongols, following their imperial policy, boosted the territorial and political ambitions of the Orbelians and Artsrunids at the expense of the Zak'arids and the Georgian Bagratid dynasty in the 1260s. Moreover, the royal Georgian House was affected greatly by enthroning two Davids. Previously, Queen Rusudan had fled to Abkhazia and then to Swanetia with her young son David Narin (Junior), whom she had placed on the throne. ${ }^{115}$ She sent David on her behalf to submit to Batu Khan (r. 1227-1255), who was in control of the Mongol troops in Russia and the Northern Caucasus at that time. ${ }^{116}$ Batu Khan sent David Narin to the Great Khan. In 1246, the Mongols brought Bagratid David Ulu (Senior), the illegitimate son of the Georgian King Lasha, from Caesarea to the throne in Tiflis. ${ }^{117}$ They sent him to the Great Khan as well. They were both received by Güyük Khan, who decreed that they should rule the kingdom in turn, first David (1247-1270, from 1259 he reigned over the eastern part of Georgia), the son of King Lasha as the elder of the two; then, following his death, his cousin David Narin (1245-1293, from 1259 he ruled the Kingdom of Imereti), son of Rusudan. The Great Khan divided the treasury of the kingdom into three parts: the priceless throne and the stunning crown allegedly belonging to Khosrov, father of Trdat the Great, the king of the Armenians, which had fallen to the Georgians, would be

${ }^{114}$ Kirakos Gandzakets'i, 1961:265.

115 David (Narin) was a son of the Georgian Queen Rusudan and the Seljuk Prince of Erzerum, a grandson of Kilij Arslan II, who embraced Christianity on his marriage in 1224 (Toumanoff in Hussey, 1966:626).

116 Kirakos Gandzakets'i, 1961:315.

117 Grigor Aknerts i i, 1974:33; Orbelian, 1910:420-421; Rusudan sent David to her daughter who had married Ghiyāth al-Dīn, the Sultan of Rūm, where he was imprisoned (Kirakos Gandzakets'i, 1961:315-316. 
sent to the Khan; and the remainder would be divided between the two Davids. On their arrival, with the assistance of Awag, David Ulu, the son of Lasha, was placed in Tiflis, and the other one in Swanetia. ${ }^{118}$ Hence, the Mongols were able to defuse the opposition by taking advantage of the internal strife within the kingdom. ${ }^{119}$

The severe taxation policy and the arbitrary nature of Mongol rule along with its rigorous requirement to participate in Mongol campaigns by acting as human shields were the key reasons for the Georgio-Armenian princes' rebellion of $1249 .{ }^{120}$ According to the Georgian sources examined by Melik'set-bek, in 1249, the GeorgioArmenian princes, including Shahnshah, Vahram Gagets'i and many others along with their troops, gathered in Tiflis in order to convince King David (Ulu) that with such a great army, they could attack the Mongols suddenly and exterminate them. ${ }^{121}$ Prince Awag intercepted this plot. On discovering this rebellion, the Mongols arrested the participants. The Mongols demanded that the rest of the princes demonstrate their loyalty to the Khan. King David and the other princes responded quickly to Chaghatai Noyan's call but in accordance with their custom, the Mongols bound their hands and feet tightly with thin cords and kept them for three days in punishment for their rebellious plan. ${ }^{122}$ Even the mother of Prince Awag came to Chaghatai to assure him of her son's loyalty. The Mongols spared the life of the king and some princes in exchange for a ransom paid by Awag. However, they killed many who had rebelled and some that had not rebelled, especially in the land of the Georgians. ${ }^{123}$ The Mongols also captured King David (Narin) the son of Rusudan, probably because of his rebellion. He was imprisoned in the province of Haband, from where he escaped to Swanetia, where he stayed until his death in $1293 .{ }^{124}$ The revolt was suppressed by Noyans Baiju and Angurag. ${ }^{125}$

${ }_{118}$ Ibid., 317.

119 The same practice of joint rule was introduced in Anatolia between two sons of Kay-Khusraw. Such arrangements of division in ruling by the Mongol government were typical in other provinces of the Il-Khanate (Melville, 2009:51-101).

${ }^{120}$ Grigor Aknerts'i, 1974:35.

${ }^{121}$ Melikset-bek, 1936:56.

${ }_{122}$ Kirakos Gandzakets'i, 1961:319-320; Grigor Aknerts'i, 1974:36.

123 Vardan Arevelts'i, 1991:148.

124 Step'annos Orbelian, 1910:406-407.

125 Melikset-bek, 1936:57. 
In 1251, before King Het'um set out on his journey to Mongolia, the Armenian Catholicos Kostandin (1221-1267), hoping to gain from this diplomatic mission strong backing for Cilician Armenia to resist the Mamluks and the Seljuks, sent a letter to Greater Armenia asking people to abstain from rebelling against the Mongols and their governors. ${ }^{126}$ This appeal worked; however, the next revolt of the Armenian princes occurred in 1259-1261. In 1259-1260, a Mongol tax called qubchur was introduced in Georgia and Armenia, which became a heavy burden for the Caucasian lords. Some of them had to mortgage their estate to pay this tax. ${ }^{127}$ This led to a rebellion of the princes against whom the Mongol ostikan (governor) Arghun conducted a military operation. ${ }^{128}$ Since Amir Arghun failed to catch the Georgian King David who fled to Abkhazia because of the heavy burden of taxes along with other impoverished princes of the provinces, he mercilessly ruined many Georgian provinces. ${ }^{129}$ According to Mkhit'ar Ayrivanets'i, in 1261, Arghun destroyed much of Georgia. ${ }^{130}$

Nevertheless, the revolt of 1259-1261 also had another aspect. Although it started as a rebellion against the conquerors, later it became a conflict among the lords as well. Smbat Orbelian's ambition for the subjection of the territories of Awag and his vassals, the Pŕoshians and Vachutians, and his exploitation of Amir Arghun's patronage brought the discontented lords to Gontsa, the Queen of Georgia. In the absence of Smbat, they attempted to encroach upon his lands and rights. On completing his journey to Mongolia and obtaining support from Amir Arghun, Smbat Orbelian put an end to this revolt. Gontsa was drowned on the orders of Hülegü Khan. ${ }^{131}$ Although Prince Shahnshah was freed for a ransom, his son Zak'arē was killed. ${ }^{132}$

Even later, the local conflicts continued. At the beginning of the 1270s, after the death of Smbat Orbelian, the Khaghbakian-Pŕoshians decided to separate their own province of Ernjak in Vayots' Dzor, which had been taken by the Orbelians, from the diocese of Siwnik'. By that time, Prosh Khaghbakian, the founder of the Pŕoshian lin-

\footnotetext{
126 Kirakos Gandzakets'i, 1961:293-310.

127 Ibid., 293-310. For qubchur tax, see Chapter 4.

128 Kirakos Gandzakets‘i, 1961:389.

129 Kirakos Gandzakets`i, 1961:389-390.

130 Mkhit'ar Ayrivanets'i, 1860:68.

131 Step'annos Orbelian, 1910:418.

132 Kirakos Gandzakets'i, 1961:391-393; Vardan Arevelts'i, 1991:152.
} 
eage, had already strengthened his position and his House through Hülegü by participating in the Mongol conquest in the Middle East. He wanted to reinstate the episcopacy of the Khaghbakians, including Ernjak. ${ }^{133}$ However, the struggle, which concerned religious and economic issues, ended in favour of the Orbelians who were backed by the Mongol governors. ${ }^{134}$

Despite the relative dearth of sources, several instances of individual contacts between the Armenian lords and the Mongols can be traced. As has been shown, there was very close collaboration between Awag Zak'arian through Chormaghan and Güyük Khan, Hasan Jalal through Sartakh and Möngke Khan, Smbat Orbelian and Möngke Khan and Hülegü, and Sadun Artsruni and Hülegü and Abaqa Khan. These partnerships paid significant dividends for both the Armenians and the Mongols. Geographically, the relationships established between the Greater Armenian lords and the Mongols, had a tendency to develop from north to south. This can be explained by the fact that the relationships between the Armenian lords and the Mongols were more intense in the northern territories of Greater Armenia during the reign of the Great Khans. The presence of Batu Khan and his offspring in the territories to the north of Greater Armenia and their supervision of the Caucasus was a strong motive for keeping the Zak'arids in power before the establishment of the Il-Khanate. By the time the Mongols settled in Iran, the influence of the northern Armenian Houses had faded and the southern Houses in Khachen and in Siwnik' had become stronger. The southern Armenian lords benefited from being closer to the centres of the Il-Khanate. The shift of Mongol power from north to south reflected the transfer of power in Greater Armenia as well. This situation suited the Mongols too because they would need reliable and loyal vassals to pursue their further imperial goals.

\section{Other Factors Influencing Mongol-Armenian Relations}

Mongol-Armenian affairs were influenced by many other factors. One of the methods of maintaining good relations was the use of diplomatic marriages between the Caucasian nobility and the Mongols. The sources mention several examples where the Armenians

133 Hovsep'ean, 1928:16-17, 36-45; Babayan, 1969:215.

134 Step'annos Orbelian, 1910:364-365. 
took Mongol spouses. Awag was given a Mongol wife by Güyük Khan. ${ }^{135}$ Bora Noyan, the son of Chormaghan was married to the daughter of Hasan Jalal. ${ }^{136}$ Smbat Sparapet was given a Mongol wife and had a son by her called Vasil Tatar, who died in a battle with the Sultan of Egypt in 1269. ${ }^{137}$ The daughter of the Georgian King Demetrē was married to Bugha Noyan. ${ }^{138}$ These marriages facilitated support for Mongol rule and also served the Armenians' cause.

It would be very useful to find some contemporary ecclesiastical sources permitting the Armenian aristocracy to have a polygamous marriage to a Mongol as well as a Christian wife. The only observation that can be made is that the state of being a vassal or being under the military and political dominion of the conquerors, meant that the Armenian Church had to deal with this phenomenon through unwritten rules or regulations, since it allowed the baptising or knighting of the children born from such marriages, as is illustrated in the case of the son of Smbat Sparapet. ${ }^{139}$ Vasil Tatar was buried in September 1269 in the holy Monastery of Mlich'. ${ }^{140}$

According to the statements of Armenian historians, the monks and lords of Greater Armenia were also employed by the Mongols as their diplomats and secretaries. Thus, in a village called Lorut, south of the Tavush fortress, Molar Noyan captured the cleric Kirakos Gandzakets' $i$, who was to serve his secretarial needs, writing and reading letters throughout the Summer of $1236 .{ }^{141}$ In 1246, Lord Vahram Gagets'i was sent to Caesarea to represent Baiju in negotiations for the liberation of David, the son of King Lasha, from prison. ${ }^{142}$ The priest Barsegh was known as Batu Khan's emissary (nkuuuu); he accompanied King Het'um (r. 1226-1270) on his journey through Caucasian Albania and the Gate of Derbent to Batu's headquarters. ${ }^{143}$

135 Kirakos Gandzakets'i, 1961:263.

136 Ibid., 391.

137 Smbat Sparapet in Galstyan, 1962:9, 122. Vasil Tatar was baptised and knighted in 1265 and was a general-in-chief of the Cilician Armenians (Smbat Sparapet in Der Nerssessian, 1973:373, 374).

138 Step'annos Episkopos, 1951:48-49.

139 Smbat Sparapet in Der Nerssessian, 1973:373, 374.

140 Smbat Sparapet in Galstyan, 1962:64.

141 Kirakos Gandzakets'i, 1961:243-252. Vanakan Vardapet and Kirakos Gandzakets'i were in Mongol captivity for one year (Davit' Baghishets'i, 1956:346).

142 Grigor Aknerts'i, 1974:33.

143 Kirakos Gandzakets'i, 1961:366, 370; Smbat Sparapet in Galstyan, 1962:49. 
The Armenian Church supported the collaboration of the Armenian lords with the Mongols. Undeniably, the fact that some of the Mongol chiefs had Nestorian Christian wives assisted the Christians in the Caucasus. Thus, in 1242, the help of Altuna Khatun made possible the return of Nersēs, the Catholicos of Caucasian Albania to his seat. While Nersēs was hidden in the monastery of Khamshi in Awag's territory, Altuna Khatun invited him to her camp in Mughan. With Awag's permission, he visited her on a special day when she was celebrating the weddings of her two children. Altuna Khatun asked her two brothers, both Christians and newly arrived from Mongolia, to honour the Catholicos and afterwards she gave Nersēs the document with the altamgha (red seal), proving his immunity from any Mongol harassment. ${ }^{144}$ In 1247, when Catholicos Kostandin (1221-1267) of Cilicia saw the ruins of Armenia and the sufferings of the people, he circulated canonical orders throughout the districts of Armenia to all bishops, monks and princes to bring church affairs into order. He sent gifts of silk clothes, expensive mantles and quantities of gold for the monastery of St. T'adeos in Greater Armenia. After the construction work had been completed, the monastery was opened with the assistance of the Mongol commander, Angurag Noyan, who had Summer quarters near this monastery. ${ }^{145}$ In the early 1250 s, Smbat Orbelian received a decree that freed all the churches and priests of Armenia from taxes. With the encouragement of General Baiju's Christian wife, Smbat renovated Siwnik's religious seat, Tat'ew. ${ }^{146}$ The Armenian monk Sergius (Sargis), who played a very active role in the court of Möngke Khan in Qara-Qorum, even attempted to baptise the Mongol Khan in 1254. ${ }^{147}$ In 1264, Hülegü received some Armenian clerics, including Vardan Vardapet, in order to explore the disposition of the ecclesiastics towards the Mongol policy. ${ }^{148}$ These examples of support for Christianity show that both in Greater Armenia and in Cilicia, the Mongols dealt sufficiently with Christian issues. They illustrate the circumstances in which Mongol-Armenian collaboration might be carried out more easily.

\footnotetext{
${ }^{144}$ Kirakos Gandzakets i, 1961:290-292.

145 Ibid., 311-312.

146 Step'annos Orbelian, 1910:412.

147 Rubruck in Komroff, 1989:138-146.

148 Vardan Arevelts'i, 2001:204-209.
} 
It is important to stress that the Armenian sources that are at our disposal can reveal two different patterns of submissions by the two different Armenian territories to the Mongols. Greater Armenia was conquered by the Mongols but Cilician Armenia surrendered voluntarily. In both cases, nevertheless, they became vassals, with different obligations.

However, the Greater Armenian lords decided to deal with this new pressure by taking individual approaches and responsibilities. The surrender of Greater Armenia proceeded by individual and separate territorial submissions. With regard to this, it is worth stressing that these individual submissions were made in a timely way, before the Mongols devastated the whole country, giving them a chance to safeguard most of the Armenian lands.

As a result, the use of Mongol power guaranteed several Armenian lords not only security in their own lands, but also an extension of their patrimony by removing their local opponents from the political arena. If the first rebellion in the Caucasus was against the repression of the Mongols, the second can be considered an internal clash between lords who were under the Georgian crown and those princes who were under Mongol patronage. In the long run, this policy of the local princes suited the Mongols. They preferred to have their own suzerainty over the Armenians and to see the Armenian lords attached to them rather than to the Georgian court, ensuring that the Georgio-Armenian lords were more disunited.

The strategy of the Greater Armenian lords towards the Mongol presence was cooperative rather than confrontational. In fact, the assistance given by Awag Zak'arian to Chormaghan and Güyük Khan; Hasan Jalal to Sartakh and to Möngke Khan; Smbat Orbelian to Möngke Khan and Hülegü; and Pŕosh Zak'arian and Sadun Artsruni to Hülegü and Abaqa Khan illustrate effective Mongol-Armenian partnerships. ${ }^{149}$

Seeing the shift of power in Asia Minor and being influenced by the example of Georgio-Armenian lords, the Armenian Kingdom of Cilicia also made a decision to submit before any Mongol intrusion into their land. The whole state thus became a Mongol vassal. In order to achieve the status of an ally, the Cilician monarch personally visited the Mongol Khan. This visit would later have strong political

149 There were 'duos' of Mongol and Cilician rulers as well (see Chapters 5, 6 and 7). 
implications for his country. Actual historical events show that this decision by the Cilician Armenians to express their loyalty to the Mongol authorities and Great Khans was just in time.

If we believe the Armenian sources, the submission was ensured by the establishment of a certain agreement between the Mongols and the Cilician Armenians. Although the existence of such a document is questionable, the whole nature of the 'agreement' illustrates the possible course and objectives of Mongol-Armenian relations and serves as an explanation of the relationship in the long term. 



\section{MONGOL ADMINISTRATION IN GREATER ARMENIA} (1243-1275)

Besides political context, the issues of Mongol-Armenian relations cover another aspect, the administrative and economic issues as well. As has been said previously, Cilician Armenia was not conquered by the Mongols and, from the time of Möngke Khan, the country maintained a degree of independence, both politically and economically. With regard to the taxes paid by the Cilician Armenians, to my knowledge, contemporary Armenian sources do not explicitly mention any of them even briefly. However, from what is mentioned by Hamd Allāh Mustawfî Qazvīnī, it is understood that Cilician Armenia paid an annual tribute of 30,000 dinars to the Il-Khanid treasury at least by the end of the Il-Khanid period. ${ }^{1}$ In comparison with the 400,000 dinars that was paid annually by the Seljuk Sultanate to the Mongol court, ${ }^{2}$ the Cilician Armenian tribute looks much lighter. Of course, like the other vassal states of the Mongol Empire, besides paying the annual tribute, Cilician Armenia was obliged to supply troops to support Mongol military actions.

While the sources do not mention Mongol taxes levied on the Cilician Armenians, they explicitly discuss those imposed on Greater Armenia. In order to stress the importance of this point, I would like to draw attention to the actual policy of Mongol taxation in Greater Armenia, specifically regarding an examination of the military and administrative institution called darughachi, which has a duty of taking a population census. A survey of the various taxes and tributes levied in Greater Armenia during the Mongol period could help in our understanding of situation.

\footnotetext{
1 Qazvīnī, 1915:100.

2 Melville, 2009:51-101.
} 


\section{Darughachis in Greater Armenia}

The matter of economic sustainability became a vital concern for the Mongols with their expansion into northern China, Transoxiana, Khurasan and then the Caucasus, when the time for plunder and rich booty was over. Controlling and ruling these lands necessitated the establishment of a governing system. The complexity of this administrative measure, or the ruling over semi-sedentary and sedentary societies, was in fact a new challenge for the Mongols themselves. The Secret History of the Mongols records:

After conquering the Sarta'ul [Muslim] people, Chinggis Khan issued a decree placing resident commanders (darughachis) in all different cities. From the city of Ürünggechi [Gurganj] came a father and son, called Yalavachi [Yalavach] and Mashut [Mas'ūd] of the Hurumsi [Qurumchi] clan of the Sarta'uls. They told Chinggis Khan about the custom and law of the balghasun [city]. ${ }^{3}$

To judge from this passage, the Mongols were keen to learn about sedentary culture. Indeed, based on their experience in dealing with Chinese cities like Namjing and Jingdu from $1214,{ }^{4}$ and after having found new ways of governing the cities of Central Asia, the Mongols put forward the idea of establishing an administrative institution, which could evolve from a military machine into a civilian office. This was the system of governors called darughachis, which was also introduced in Armenia. ${ }^{5}$ The structure of this system varied in each country, based on local conditions. ${ }^{6}$

${ }^{3}$ MNT, 2004:92(\$263). Maḥmud Yalavach, a Khwārazmian Turk, was in charge of administering most of East and West Turkestan. In 1241, he was put in charge of North China. His son Mas'üd Beg replaced him as the Mongols' chief administrative officer in Central Asia (Allsen, 1983:252).

${ }^{4}$ MNT, 2004:85-86(\$251-253); SHM, 2001:238-240. Namjing (Nanjing) is present day Kaifeng in Henan Province (Onon Urgunge, 2001:239). Later in 1234, Ögedei Khan appointed resident commanders in these cities (MNT, 2004:96[\$273]; Ostrowski, 1998:262-263).

${ }^{5}$ Darugha is a governor, and the Turkic-Mongol suffix chi indicates the agent who performs the function (Ostrowski, 1998:262). Cleaves suggests that darughachi or darugha constitutes one of the key terms in the administrative vocabulary of thirteenth to fifteenth century Mongolian texts (Cleaves/Darugha, 1953:238).

${ }^{6}$ Buell considers that, though it is certain that the first darughachis were appointed by the Mongols for China (seemingly as early as 1214), the area of the Mongol Empire, in which the darughachi system was first fully developed was Turkestan (Buell, 1979:133). 
Before discussion of the darughachis institution, we should consider how the Mongol Empire was organised. The eventual administrative division of the Mongol Empire among the sons and relatives of Chinggis Khan formed separate successor states called ulus. ${ }^{7}$ The number of uluses was not limited only by the territories of Chinggis Khan's four sons. The territories given to Chinggis Khan's brothers and the rest of his family members were uluses as well. ${ }^{8}$ Chinggis Khan gave all the lands to the west of the Irtysh, the Aral Sea and the Amu Darya to the Ulus of Jochi. ${ }^{9}$

However, Georgia and Armenia were not included in the Ulus of Jochi. ${ }^{10}$ They were under the supervision of the Mongol noyans who were interested in keeping the Caucasus area within the orbit of the vast Mongol domain. ${ }^{11}$ It is hard to know who was in charge of Arran, Shirvan and Azerbaijan (Atrpatakan). Vașșaf states that Azerbaijan and Arran were territories of Batu and his line. ${ }^{12}$ Nonetheless, from 1236 to 1258, these territories represented separate regions ruled by a Mongol governor-general. The first Mongol governor-general in this region was Chormaghan. ${ }^{13}$ The Mongolian text of the Secret History clearly says that Chormaghan was appointed by Ögedei Khan as tamghachi, which is translated into English as 'garrison commander.' ${ }^{14}$ Rashīd al-Dīn states that Ögedei Khan sent Chormaghan to this region as lashkar-tamma along with an army of 40,000 soldiers. ${ }^{15}$ According to Rashīd al-Dīn, the lashkar-tammā was

\footnotetext{
7 On successor uluses of the Mongol Empire, see the Introduction and Jackson, 1999a:709.

${ }^{8}$ MNT, 2004:80-81(\$242-243); Jackson, 1999b:36.

9 The Ulus of Jochi or later the Golden Horde was the inheritance of Chinggis Khan's son Jochi and grandson Batu with its key base in the Pontic and Caspian steppe and its capital at Sarai. In the quriltai of 1235, it was decided to launch an expedition to Russia and Eastern Europe. In 1236, Batu started his conquest of Russia. The Golden Horde ruled over Russia until 1480 (Halperin, 1985:100).

${ }_{10}$ The initial Ulus of Jochi included the vast territories of West Siberia, Kazakhstan and the lower basin of Syrdarya (Vernadsky, 2001:144).

11 Tizengauzen, 1884:245; Vașșāf, 1856:93.

12 Vașșāf, 1856:93.

13 Juvaynī/Boyle, 1997:482-483.

14 MNT, 2004:96(\$274); SHM, 2001:267. Presumably, the institute of military governor was called in Mongolian tamghachi [tamgha + chi], the holder of the state tamgha (seal). This is different from the tamghachi as tax collector ( $c f$. Doerfer, 1965(Vol. 2):565-566.

${ }_{15}$ Rashīd al-Dīn, 1952(Vol.1, part 1):98-99. Seemingly, tammachi (tanmachi in the Yüan Shih) was in charge of the military formation called tammā, which operated as security forces in the occupied lands. There is another definition of this term, which says that lashkar-tamma was an auxiliary force that consisted of various
} 
known as the head of a special garrison of selected soldiers who were sent out from the main body of the imperial army for permanent residence in certain places. ${ }^{16}$ Regardless of the differences in the naming of this office, Chormaghan held the post of military governor.

Georgia and the territories of the Zak'arids, Greater Armenia (southern and western Armenia), along with Shirvan, Arran and Mughan, and Azerbaijan were first known as the five vilayets of Chormaghan. Within Armenia, as Grigor Aknerts'i points out, at the local quriltai (assembly) called by Chormaghan, the Mongol noyans divided Armenia into three parts: northern (Georgia and the Zak'arids' principality); inner (western Armenia); and southern Armenia. ${ }^{17}$

The Georgian and Zak'arid holdings, including Ayrarat, Siwnik' and Arts'akh, were known as the Gurjistan vilayet (province of Georgia) which had been divided into eight tumans, five of which belonged to the Georgians. The remaining three tumans were Armenian, i.e., the territories of the Zak'arids of Ani and Kars; of the Awagids in Siwnik' and Arts'akh; and of the Vagramids (Gag, Shamkor and the surrounding area)..$^{18}$ The tuman was an administrative unit, and, being derived from its basic military meaning, was able to mobilise 10,000 soldiers.

The governing model was different in each vilayet. In general, the Mongols tried to use local, already existing, social formations. ${ }^{19}$ For instance, from 1236 until 1246, the Mongols did not intervene in the governing structure of the Za'karids. In the absence of Queen Rusudan, Eastern Georgia and Armenia were ruled by the Zak'arid princes, ishkhans. ${ }^{20}$ Apparently, they were appointed as heads of tumans. ${ }^{21}$ By this, local custom coincided with that of the Mongols. Only in 1246, the Mongols brought David, the son of the Georgian

nationalities, and only the commanders were Mongols (see Doerfer, 1963[Vol. 1]:255-256; cf. Ostrowski, 1998:264-270).

${ }_{16}$ Rashìd al-Dīn, 1952(Vol. 1, part 1):99.

17 Grigor Aknerts'i, 1974:26.

18 Babayan, 1969:120.

19 Manandian, who wrote his work in Soviet times, considers that the Mongols, being nomads, in terms of social development were at a lower level than the Armenians and the Georgians, therefore they were unable to change the existing formation in all the lands they conquered (Manandian, 1952:245).

${ }^{20}$ Kirakos Gandzakets'i, 1961:263.

${ }^{21}$ According to the local terminology, the head of tumans were hākims and maliks (Babayan, 1969:120). 
King Lasha, from Caesarea; his reign lasted until 1270.22 Therefore, Eastern Georgia and Zak'arid Armenia were double vassals of the Georgian King and of the Mongol Khan. ${ }^{23}$

In contrast, by the second half of the thirteenth century, the Mongol system of ownership was introduced in southern and western Armenia, known as the vilayet of Greater Armenia. ${ }^{24}$ The Mongols used this land as their Summer and Winter base. Local governors were dismissed and the Mongol nobility owned the land as enchü / injü, a land allotted to the ruling family. ${ }^{25}$ However, within the vilayet of Greater Armenia, some principalities of the Taurus Mountains, particularly the T'ornik branch of the Mamikoneans in Sasun, and the Vaspurakan branch of the Artsrunids in Mokk and Ŕshtunik, as well as some mountainous Kurdish and Seljuk families, saved their lands by recognising the Mongol rulers and entering into vassalage. The Artsrunid island of Akht'amar, and the cities of Erzinjan (Erznka) and Khlat (Akhlāt) also preserved their autonomy. The centre of this vilayet was the city of Karin (Erzurum). ${ }^{26}$

As elsewhere, the Mongol administration in the Gurjistan vilayet set two goals in order to mobilise the wealth of all subjugated countries, to conduct a census and extract taxes. ${ }^{27}$ These goals were implemented by the new institution of governors, darughachi or basqaq.

As has been mentioned above, the term tamghachi describes a personal representative of the Khan who held the state seal tamgha, and Chormaghan, as the tamghachi of the region, exercised full power with a wide range of functions: Political, military, civil, and administrative, as well as financial. According to Kirakos Gandzakets' $i$, he was also a judge (yarghuchi). ${ }^{28}$ Both tamghachi and yarghuchi were appointed by the central government; they were in charge of monitoring administration and justice. ${ }^{29}$ This can be illustrated by a

\footnotetext{
${ }^{22}$ Grigor Aknerts'i, 1974:33; Orbelian, 1910:420-421.

${ }^{23}$ Only from 1256 until 1344, Armenia was a part of the Hülegü's appanages.

${ }^{24}$ Babayan, 1969:121.

${ }^{25}$ Ibid., 121. For more details on enchü (injü), see Lambton, 1953:78; Scherbak, 1997:194-195; Doerfer, 1965(Vol. 2):220-225.

${ }^{26}$ Babayan, 1969:121.

27 The identification of natural resources was also the purpose of a census (Allsen, 1987-1991:32).

${ }^{28}$ Kirakos Gandzakets'i, 1961:275. Yaruga or jaruga in Mongolian means 'lawsuit,' 'litigation,' and yarghuchi (yarugha+chi) is a 'judge' (Lessing, 1973:1037; cf. Doerfer, 1975[Vol. 4]:64-66).

29 Ratchnevsky, 1991:176.
} 
passage from the Secret History of the Mongols. When Batu, the grandson of Chinggis Khan, complained to Ögedei Khan about the claim of Güyük and his colleagues regarding the issue of seniority between Batu and Güyük, Ögedei became very angry with Güyük and refused Güyük an audience, saying:

I shall make of him a scout,

So that he must climb

City walls like mountains,

Until his ten fingernails drop off.

I shall make of him a tamghachi,

So that he must climb

Hard-pounded city walls

Until his nails of five fingers splinter. ${ }^{30}$

On the basis of what was said about Güyük, the next Great Khan, it can be supposed that the position of tamghachi was an arduous one in the echelons of power. It can also be assumed that the main duty of tamghachi was to combat and besiege cities. ${ }^{31}$

The tamghachis were supported by local governors, darughachis, the heads of garrisons left behind in conquered towns and districts. ${ }^{32}$ Juvaynī states that Ögedei Khan issued a decree (yarligh) that the leaders (سروران presumably, darughachis) and basqaqs (bāsqāqs) from every place should accompany the levy and render assistance to Chormaghan. ${ }^{33}$ In secondary literature, the term darughachi is glossed as 'an official who is entrusted with a seal. ${ }^{34}$ Here, an issue may arise about the relative ranks of tamghachi and darughachi; nevertheless, whether tamghachi or darughachi, it relates to the institution or office created by the Mongols to interact with local society in conquered countries. ${ }^{35}$ There was no obvious trace of any similar institution functioning in the Mongol homeland, so, apparently, this office was intended to deal with non-Mongols in non-Mongol lands. The darughachis were the most important officials, exercising great power in the area to which they were assigned and they were respon-

${ }^{30}$ MNT, 2004:97(\$276); SHM, 2001:269.

31 Ostrowski, 1998:263.

${ }^{32}$ MNT, 2004:96(\$273-274, 281).

33 Juvaynī/Boyle, 1997:482.

34 Ratchnevsky, 1991:259(note 177); Doerfer, 1963(Vol. 1):319-323.

35 Buell's hypothesis supported by Morgan on the Khitan origin of darughachis is unproven historically and philologically (Endicott-West, 1989:151[note 55]). However, Ostrowski tends to see more Chinese influence in the origin of this institution (Ostrowski, 1998:276-277). 
sible for conducting the census, collecting taxes, being in charge of the courier service, and of levying troops from among the local people.

The Mongolian darugha or darughachi is derived from the root daru, which means to press or suppress, and could be interpreted as oppressor. ${ }^{36}$ Semantically, the Turkish equivalent of darughachi is basqaq; the Arabo-Persian version is shahna. ${ }^{37}$ In Armenian sources, it appears as ostikan (governor): 'They left evil ostikans in charge of the land,'38 or as shahna: 'They took Erznkay first of all and left a shahna. ${ }^{39}$

Since this darughachi had soldiers under his command and the office was in a transition stage from military to civil, in Armenian sources they are also referred to as chieftain (qLuuunn) or chief of chiefs (uıuuquig uıuı): 'They left a chieftain (glkhavor) called Ghara Buqa. ${ }^{40}$ In Orbelian, awagats' awag (chief of chiefs) stands for darughachi: 'Buqa, who was called awagats' awag,'41 and pasghag (basqaq): 'They have gathered in Tiflis to Arghun [Aqa], who was vazir and pasghaq [overseer] over all lands and was appointed by the great Khan. ${ }^{\prime 2}$

The official function of darughachi and basqaq was not clearly defined, although it is believed that the term basqaq was used in the eleventh century. ${ }^{43}$ Scholars claim that darughachi and basqaq are recorded separately ${ }^{44}$ and that the rank of basqaq was subordinate to that of darughachi. ${ }^{45}$ This view has been based more on which nation-

${ }^{36}$ For more on darugha, see Cleaves, 1953:237-255; Vernadsky, 1953:211-212, 219-220; Doerfer, 1963(Vol. 1):319-323; Vásáry, 1978:201-206; Allsen, 1981:41; Morgan, 1982a:129; Ostrowski, 1998:262-277.

${ }^{37}$ Juvaynī/Boyle, 1997:44(note 3), 105(note 24); Morgan, 1990:108-109. Some scholars refer to darughachis as the officers in charge of taxes and to shahnas as civil governors (Grekov, 1953:686). The term daruga was used in Șafavid Administration (Minorsky, 1943:141).

${ }^{38}$ Kirakos Gandzakets'i, 1961:361.

${ }^{39}$ Grigor Aknerts'i, 1974:30.

40 Ibid., 23.

${ }^{41}$ Step'annos Orbelian, 1910:430. Buqa Chink'san[k], from the Jalayir tribe, rebelled against Arghun Khan and was killed by the latter in 1289 (Step'annos Episkopos in Hakobyan, 1951:49).

${ }^{42}$ Step'annos Orbelian, 1910:412.

43 On the origin of the institution of basqaqs, see Vásáry, 1978:201-206.

${ }^{44}$ Endicott-West in her study of the office of darughachi (ta-lu-hua-ch'ih) in China, believes that the functions of the offices of basqaq and darughachi varied (1989:18-19, 35).

${ }^{45}$ Spuler, 1943:303; Vásáry, 1978:201; Ratchnevsky, 1991:138-139. 
alities held this office rather than on the basis of function. ${ }^{46}$ Some explain that darughachis were Mongol persons or persons regarded as equivalent to the Mongols, ${ }^{47}$ while basqaq were local officials. ${ }^{48}$ Others say that a darughachi was often a Uighur and sometimes a Persian. ${ }^{49}$ Summing up these views, it can be said that darughachis possessed the authority to take decisions and dealt with administration in general, while the routine work of administration was delegated to basqaqs. ${ }^{50}$ According to Chinese sources, the taxation system in China was based on the homestead principle, therefore darughachis were appointed by Ögedei Khan in order to control the situation in addition to local tax collectors. ${ }^{51}$ As elsewhere, the Mongols adopted a policy of appointing two government officials to one post in order that they could control each other. In the case of Greater Armenia, this post was assigned to Oirat Arghun Aqa and Jochid Töre Aqa (T'ora Agha in Armenian sources). ${ }^{52}$

The governors or darughachis were assigned to deal with the administrative problems of the whole city or region under the supervision of the rulers. The general scheme of Mongol administration in Zak'arid Armenia, before its annexation to the Il-Khanate had the following structure (1236-1256/58):

Great Khan

- Georgian King

- Princes (ishkhans) or heads of tumans

In other parts of Greater Armenia, it was as follows (1248-1256/58):

Great Khan

- Governor-General (tamghachi)

- Darughachi / basqaq

${ }^{46}$ Though the roles of the offices often overlapped, one suggests that tammas (Mongol) and basqaqs (Persian and Turkic) were military overseers, while shahnas (Persian) and darughachis (Mongol) were civilian officers (Ostrowsky, 1998:262277; Lane, 2003:166).

${ }^{47}$ Initially, at the time of setting up the Il-Khanate, Oirat Arghun, known as Arghun Aqa and Uigur Körgüz were entrusted with great power ( $c f$. Morgan, 1990:109-110). For Chinese examples, see Endicott-West, 1989:86-87.

${ }^{48}$ Ratchnevsky, 1991:138.

${ }^{49}$ Grousset, 1970:243.

${ }^{50}$ Lambton, 1953:424. Basqaqs' main duty was the inner protection of the subjugated lands and this institution lasted in Rus' until the 1320s (Vásáry, 1978:201; Vernadsky, 1953:220).

${ }^{51}$ Munkuev, 1965:47.

52 Kirakos Gandzakets'i, 1961:261-262. 
In the successor states, it was as follows (1256/58-1344):

\author{
Great Khan \\ - Blood prince (ruler of Ulus) \\ - Darughachi / basqaq
}

The actual number of darughachis in the Caucasus is unknown. In some areas of the empire, the number of officials was high. For example, in 1231, when the Korean capital Kaesong had been taken by the Mongols, 72 darughachis were placed under the Mongol protectorate to run it. ${ }^{53}$

The whole institution of darughachis / basqaqs was set up to maintain a far greater use of population and natural resources. This system applied to Georgia and Armenia right from the beginning of the conquest, based on the Mongols' prior experience of this institution in China.

As elsewhere, the establishment of the institution of darughachi in Armenia had far-reaching consequences. The darughachis started to conduct a census of the population, and a registry of land, livestock and possessions. This was a starting point for the permanent economic use of Greater Armenian territories. The introduction of the Mongol fiscal administration influenced the political status of Armenia, developing it from a vilayet to an administrative province of the Mongol Empire.

\title{
Mongol Census-taking in Greater Armenia
}

The Mongol census, taken throughout the 1250s in all parts of the Mongol Empire, was a decisive moment for the regulation of the economy in the conquered lands, because it was designed to control and mobilise human and non-human resources. It had importance for Armenia as well, because it signified a new stage in the history of the Armenian people, the process of their affiliation to the Mongol Empire. Before the actual censuses, the Georgio-Armenian princes were obliged to pay tax and to provide all necessities, including horses, guides, dwellings, food and carts to the Mongol governors who held the paiza (tablet of authority). ${ }^{54}$ However, among the

\footnotetext{
53 Grousset, 1970:259.

54 Manandian, 1952:246.
} 
censuses taken in Armenia in the $1250 \mathrm{~s},{ }^{55}$ the most important census was that of 1254, which was intended to put Armenia under the central registration of the Mongol Empire.

The census of 1254 was conducted by Amir Arghun or Arghun Aqa ${ }^{56}$ and implemented by Buqa ${ }^{57}$ in Greater Armenia. In general, data collection was based on the household..$^{58}$ Unfortunately, the Armenian sources do not give any reliable details about the size of the population. According to Manandian, the number of peasants during the reign of King David VII Ulu (1247-1270), the son of Lasha, was about one million, and the whole population of Georgia, including Armenia, was four to five million. ${ }^{59}$ However, the Armenian sources are very informative in terms of the sex or age of people entered in the Mongol registers. The youngest was eleven, ${ }^{60}$ or fifteen $^{61}$, and the oldest was sixty years old. ${ }^{62}$ The registers covered all the male population and excluded women. ${ }^{63}$ However, according to some sources, taxes were levied on women and children as well. ${ }^{64}$

The entry of women and children later into the Mongol rolls can be explained by the fact that the registration of the male population was carried out separately, and the reason for this is the utilisation of manpower for military service. An anonymous Georgian chroni-

55 According to Vardan Arevelts'i there was a Mongol census-taking in Armenia in 1243/1244 (Vardan Arevelts'i, 1991:147-148). This information seems plausible, since there was a census taken in Iran in 1240 (Allsen, 1987:130).

${ }_{56}$ Arghun's father Taichu was the Commander of a Thousand (Juvaynī/Boyle, 1997:505). Rashīd al-Dīn states that Arghun's father, whom he does not name, in time of famine, sold his son in exchange for a leg of beef to a certain Kadan of the Jalayir tribe (Rashīd al-Dīn, 1952[Vol. 1, part 1]:95). For Arghun' career, see Lane, 1999:458-482, 2003:177-212. Kolbas identifies Arghun Aqa as the man who shaped Iran in the middle period of Mongol rule (Kolbas, 2006:121).

${ }^{57}$ Buqa was from the powerful Jalayir tribe, and was titled Chink'san[k] ('minister' in Chinese) in 1286. Being so elevated, he sought to conspire against Arghun Khan in 1290. The intrigue was discovered and Arghun killed Buqa and all his male offspring. The Georgian King Demetre was also killed on the plain of Mughan on the bank of the River Kur, for he had married his daughter to Buqa (Step'annos Episkopos in Hakobyan, 1951:48-49). Buqa caused the Armenians great suffering, which was described by Frik, the Armenian poet of the thirteenth century, in his verse About Arghun Khan and Buqa (Frik, 1952:38-43).

${ }^{58}$ Allsen, 1987:119.

59 Manandian, 1952:251.

${ }^{60}$ Kirakos Gandzakets'i, 1961:362.

${ }^{61}$ Grigor Aknerts'i, 1974:37.

${ }^{62}$ Kirakos Gandzakets'i, 1961:362; Grigor Aknerts'i, 1974:37.

${ }^{63}$ Kirakos Gandzakets'i, 1961:362.

${ }^{64}$ Sebastats'i in Hakobyan, 1956:141; Vardan Arevelts'i, 1991:148. 
cler, relating Arghun's census of 1254, says that Arghun had to calculate the number of cavalry men and soldiers who could participate in raids along with noyans, and he registered one out of every ten peasants who had good land. ${ }^{65}$

The other anonymous Georgian source states that the Mongols were taking one man from ten peasant houses for military service. ${ }^{66}$ Northern or Zak'arid Armenia was obliged to provide 30,000 horsemen. From this account, it is estimated that the population of Zak'arid Armenia reached around 270,000 peasant houses. ${ }^{67}$

During the process of conducting the census, in the key cities, the Mongols set up so-called divans, the chancery where davtars, or registry books, were kept. ${ }^{68}$ Grigor Aknerts'i records:

A Tat'ar chieftain, Arghun by name, came by the command of Manku Ghan [Möngke Khan] and took a census of the eastern country for the taxes. From this time on, they were taking taxes according to the number of heads of the people, as many as were inscribed in the books. ${ }^{69}$

According to Orbelian, the divans were reported to be in QaraQorum, Tiflis and in Davrezh (Tabriz). ${ }^{70}$ Bitikchis, the scribes or secretaries, ran the chancery. ${ }^{71}$

The category of male adults exempt from registration was the clergy. The Armenian sources state this explicitly. By not being included in the rolls, the Armenian clergy exercised a great deal of freedom from corvée and military obligation and received immunity from poll tax. This situation was common elsewhere in the Mongol Empire, and can be considered a political tool for the Mongols to attract ecclesiastics to cooperate with them. ${ }^{72}$

Because the census imposed obligations on the registered population, such as 50 spitak or silver coins from each accounted person in Armenia, there were attempts to avoid the registration. In order to

${ }^{65}$ Manandian, 1952:251.

${ }^{66}$ Anonymous Georgian source quoted in Manandian, 1952:250-251. For common figures in Mongol raids, see Amitai, 1987:236-255.

${ }^{67}$ Grekov, 1953:682.

${ }^{68}$ Step'annos Orbelian, 1910:411,427.

${ }^{69}$ Grigor Aknerts'i, 1974:37. In China, the registry books were called blue registers (Allsen, 1987:119).

${ }^{70}$ Step'annos Orbelian, 1910:408-411, 426.

${ }^{71}$ Kirakos Gandzakets'i, 1961:275.

72 Allsen, 1987:121. 
discourage this, cruel penalties were imposed on those who attempted to escape the census-takers. ${ }^{73}$

The census pursued not only fiscal and military goals, but was also an inventory of the skills of the population. In Greater Armenia, as elsewhere in the Mongol Empire, all artisans, whether in cities or villages, were registered and taxed. ${ }^{74}$ The census was also a survey of the economic resources of empire, or in the broadest sense, it was a preparation for further conquest. ${ }^{75}$

According to Allsen, census-taking in this vast empire denoted an imperial policy geared up for the long-term systematic exploitation of subject people. ${ }^{76}$ The census of 1254 in Armenia followed this pattern and therefore had a practical result. In 1256, the Caucasus was incorporated as a part of the hereditary territories of Hülegü or the Il-Khanate. ${ }^{77}$

There were a few more censuses conducted in Armenia, probably in 1273 [1275], according to Step annos Episkopos, ${ }^{78}$ and in 1314, according to the colophons, in which it is said that, in 1314 (763 Arm.), the [Mongol] census-takers arrived in Vayots' Dzor, and they registered even a month-old child. ${ }^{79}$ At the beginning of the fourteenth century, there was almost no control coming from the central imperial administration, therefore the census-taking was conducted by the Il-Khanid court and it seems that it was carried out to include every newborn child. In this sense, the roll aimed at the policy of mass taxation to project future resources to support the Mongols' further campaigns. ${ }^{80}$

${ }^{73}$ Grigor Aknerts'i, 1974:37.

${ }^{74}$ Kirakos Gandzakets'i, 1961:362.

${ }^{75}$ Allsen, 1987:124.

76 Ibid., 125.

77 Manandian, 1952:244; Babayan, 1969:153; Bedrosian in Hovannisian, 1997: $259-260$.

${ }_{78}$ Step'annos Episkopos in Hakobyan, 1951:44.

${ }^{79}$ Khach'ikyan, 1950:104; Sanjian, 1969:58.

${ }^{80}$ The general poll-tax (sar-shumārā) introduced by the Mongols in Iran must not be confused with the jizya, the ancient poll-tax based on Muslim law and exacted from non-Muslims. After the Mongol conquest, jizya ceased to exist but was restored by Öljeitu in 1306 (Petrushevsky, 1968:533). 


\section{Tributes and Taxes}

The census identified the actual number of people that could be taxed systematically. The taxation itself required a system, especially if it related to vast territories like the Mongol Empire. Due to Möngke Khan, the fiscal system of the Mongols was augmented and gradually unified towards the second half of the thirteenth century. Studying the comparative perspectives of Russia and the Mongol Empire, Halperin once said that it is impossible to compare the levels of taxation in different Mongol successor states. Both Iranian and Mongol taxes flourished in the Il-Khanid territories; however, no-one can identify which was which. Surely, the Mongols would not mistakenly levy tax on furs in China or rice in Russia. ${ }^{81}$ The same can be said for Armenia. In order to introduce the economic condition of Greater Armenia during its supervision by the Mongol noyans and the Il-Khans, it is intended to list some taxes, levied by the Mongols in Armenia, which are found in the Armenian sources, and which might help to clarify the nature of Mongol taxation in conquered territories.

Among the taxes and levies that the Mongols introduced in Armenia, there was a typical Mongolian tribute called qalan and a levy called qubchur. Later, under Hülegü, a tax called taghar was brought into Armenia. ${ }^{82}$

1. As has been mentioned before, the census covered mostly the male population, although there were cases that included women, children and the elderly. ${ }^{83}$ This registration obliged the Georgian and Armenian princes willingly or unwillingly to give tribute to the Mongols in order to provide cavalry troops for Mongol military action. ${ }^{84}$ This service was called qalan or khalan in the Armenian sources. ${ }^{85}$

Qalan in Grigor Aknerts'i and Rashīd al-Dīn was rendered as a tribute of military service or a payment for exemption from Mon-

81 Halperin, 1983:244-246.

82 Qupchur is khap'chur in Kirakos Gandzakets'i, 1961:374.

83 Sebastats'i in Hakobyan, 1956:141; Vardan Arevelts'i, 1991:148. Supposedly, this act of imposing tax on women and children in Armenia was questioned at the central court by Arghun Aqa (Allsen, 1987:167).

84 Grigor Aknerts'i, 1974:26.

85 Ibid., 26, 35. 
gol military service. ${ }^{86}$ The root khal (khalaa) in Mongolian perhaps meant and today means replacement, and it is usually used for the recruitment of soldiers. ${ }^{87}$ Therefore, qalan was the tribute paid to recruit soldiers on an occasional basis as was practised everywhere, including Georgia, Armenia and Iran. As was noted in Armenian sources, two men out of ten were obliged to serve in the Mongol army. ${ }^{88}$ According to this obligation, the Georgio-Armenian army participated in Hülegü's conquests of Baghdad in 1258 and Syria in $1260 .{ }^{89}$ Qalan may correspond to the Armenian tribute known as hetsel, the cavalry vassal obligations. ${ }^{90}$

2. Another Mongolian tax introduced in Armenia was qubchur, originally a herd tax. ${ }^{91}$ Qubchur (gobchur) in Mongolian meant a tribute on flocks and herds and the root qubchi still means in modern Mongolian 'to put a saddlecloth on the back of an animal. ${ }^{92}$ Originally, Ögedei Khan had decreed that each military tuman must contribute one three-year-old sheep from every herd to the royal court and one sheep out of a hundred to the poor and needy every year. ${ }^{93}$ Therefore, initially, the rate of qubchur in all conquered lands was one per cent. ${ }^{94}$ This tax grew more complicated during the Il-Khanid period, when it became a levy or additional tax imposed on the conquered population. Later, it stood as a general term for tax, in some cases meaning poll-tax. ${ }^{95} \mathrm{Qubchur}$ was collected many times a year if the original levy did not provide a sufficient fund, even 20 or 30 times, if we believe the Persian source. ${ }^{96}$

${ }^{86}$ However, according to Petrushevsky, qalan and qubchur in Iran were used instead of kharaj (Petrushevsky, 1968:532). The thirteenth century Persian poet Pūr-i Bahā, the panegyrist of the Juvayni family, in 1264 wrote a 'Mongol' ode that was translated by Minorky. This poem is an account of historical events that occurred on the frontiers of Khurasan with a vast number of Mongol technical terms including taxes in Iran under Mongol dominion (Minorsky, 1964c:274-305).

${ }^{87}$ Tsevel, 1966:647; Lessing, 1973:916. Qalan is also associated with another Mongol tribute called alban (Smith, 1970:48; Lambton, 1988:200).

${ }^{88}$ Grigor Aknerts'i, 1974:49; Grekov, 1953:682.

${ }^{89}$ For the campaigns of Hülegü and other Il-Khans, see Chapter 5.

90 The term hetsel is found in one of the undated inscriptions of Ani (Kostaneants', 1913:221; Babayan, 1969:251).

${ }^{91}$ For qubchur or alba qubchur, see Schurmann, 1956:325-330; Doerfer, 1963(Vol. 1):387-391; Lambton, 1988:199.

92 Tsevel, 1966:146; Lessing, 1973:363.

${ }_{93}$ MNT, 2004:99(\$279).

${ }_{94}$ Petrushevsky, 1968:530.

95 Allsen, 1987:153; Lambton, 1988:199.

96 Rashīd al-Dīn, 1946(Vol. 3):248. 
It was levied in coins, in accordance with the wealth of the person and his ability to pay. ${ }^{97}$ In the case of Armenia, it was 60 spitak (silver coins) per head. ${ }^{98}$ It is worth noting that revenue collection in the form of money was preferred within the Mongol Empire, because it was economically feasible to ship cash over great distances and convert it into some other type of goods or services. ${ }^{99}$

3. Taghar was a levy on food and provisions. In West Asian sources, it also meant an extraordinary levy to sustain the imperial army while on campaign. ${ }^{100}$ Taghar in Mongolian is a sack or a bag, used mostly for provisions. ${ }^{101}$ This was a widespread tax in the territories of the Mongol Empire, where the economy was based on agriculture. The culminating point of this tax had been reached in China during the period of the Yüan Dynasty, where the taghar as a levy on crops was taken from each male head and from each land. ${ }^{102}$ The following describes taghar in Armenia:

Hülegü commanded that the tax called t'aghar be collected from each individual listed in the royal register. From such they demanded one hundred litrs [pound] of grain, fifty litrs of wine, two litrs of rice and husks, three sacks, two cords, one spitak [silver coin], one arrow, let alone the other bribes; and one in every twenty animals plus twenty spitaks. ${ }^{103}$

Juvayni relates that the dispatch of taghars of flour for provisioning the army covered an area from 'Armenia to Yezd [Yazd] and from the land of Kurds to Jurjān,' which was procured by the elchis (envoys) who were in charge of their transportation. ${ }^{104}$ The year 1256 was when Armenians played a part in the Mongol war with the Ismāîlis by providing most of the provisions for the Mongol armies. ${ }^{105}$ If all the food levies of ulagh (see further) and taghar were imposed with no exception, it seems that Greater Armenia

\footnotetext{
${ }^{97}$ Juvaynī/Boyle, 1997:517. A hexagon-shaped coinage for the imperial tax qupchur was minted in Tabriz (Kolbas, 2006:196).

${ }^{98}$ Grigor Aknerts'i, 1974:37.

99 Allsen, 1987:172.

${ }^{100}$ Ibid., 186.

${ }_{101}$ Doerfer, 1965(Vol. 2):512-519; Tsevel, 1966:509; Lessing, 1973:764.

102 Yüan Shih, Chapter 93, in Dalai, 2003:219.

${ }^{103}$ Kirakos Gandzakets' $i, 1961: 374-375.1$ litr of wine is equal to 2/5 litre, 1 litr of rice is $0,5 \mathrm{~kg}$ (Manandian, 1952:277).

${ }^{104}$ Juvaynï/Boyle, 1997:621. For the provisioning of large armies campaigning over extraordinary distances, see Smith, 1984b:223-228.

105 Rashīd al-Dīn, 1946:30.
} 
faced economic crisis in 1256. The repercussions of these taxes brought famine to Armenia. ${ }^{106}$

4. Besides these three major taxes, there were other taxes. One was called the tamgha, a toll on commercial goods, as well as a licence for commercial acts. ${ }^{107}$ The collector of this tax was called the tamghachi, for he put a tamgha (seal) on goods for sale, similar to a customs' stamp. ${ }^{108}$ In the Armenian inscriptions of the city of Ani, dated 1270 (719 Arm.), the tamgha was used together with the baj, the local Armenian term for the custom, or duty tax. ${ }^{109}$ The precise rate of the tamgha is not known. It was levied at varying rates and a substantial part of the revenue of the empire was derived from it. ${ }^{110}$ Initially, it was levied at ten per cent of the value of each commercial transaction. ${ }^{111}$ In 1257 , the Genoese frequently traded through Kars involving Zak' arid Armenia in the Black Sea trade. ${ }^{12}$ Caravan routes passing through Trebizond, and the cities of Erzurum, Berkri, and Khoi in Greater Armenia, were connected with the Italian trading republics. ${ }^{113}$ Apparently, this was a very profitable business for the Mongols if we consider that Hülegü's conquests were financed under the tamgha tax. ${ }^{114}$ The trade usually was centralised near the royal court, therefore the tamgha maintained the Il-Khanid court, army and civil administration. ${ }^{115} \mathrm{On}$ the other hand, the burden of the tamgha caused the Il-Khan Ghazan to cut this tax by half, from ten to five per cent of the value of each transaction in towns. ${ }^{116}$

106 Sebastats' $i$ in Hakobyan, 1956:142.

107 For the tamgha, see Doerfer, Vol. 2, 564-565. For the commercial taxes in the Il-Khanate, see Pemler, 1985:157-177.

${ }^{108}$ Kirakos Gandzakets'i, 1961:277.

109 Kostaneants', 1913:221; Basmadjian, 1922:23, 337. The Armenian baj may derive from the Persian term $b \bar{a} j$, a tribute on trade ships (Rashīd al-Dīn, 1946(Vol. 3):25.

${ }^{110}$ Lambton, 1986:84 (Nuzhat al-qulūb, text 1915). Qazvīnī mentioned twenty cities in Iran where the tamgha was levied (Strange, 1919:113).

111 Petrushevsky, 1968:532.

112 Manandian, 1965:187. Armenia had had trade relations with Genoa since the beginning of the thirteenth century (Alishan, 1893:437-438).

113 Manandian, 1952:260-263.

114 Kolbas, 2006:201. Hülegü's Syrian campaign was subsidised by Anatolia as well, where the annual tribute reached the sum of 20 tumans in cash, 3,000 gold bars, 1,000 horses and mules, and 500 rugs and satin textiles (Āqsarā'̄ì, 1944:62-63, 73).

115 Boyle, 1968:508.

116 Ibid., 532. 
The basic tax terms that were used and introduced by the Mongols, namely qubchur, qalan, taghar and tamgha, had different meanings in different places. Thus, qubchur in Iran meant also a poll tax levied on the subject population. ${ }^{117}$ On every occasion that a census was held, the qubchur was reassessed. Being fixed at the rate of 70 dīnārs per 10 persons ( 7 dinnār per person) in 1258, based on a new census, the qubchur ranged in scale from 500 dinnārs for a wealthy person to one dinnarr for the poor. ${ }^{118}$ Thereafter, the imposition of the census and poll tax qubchur seems to have become a regular procedure. Under Ghazan Khan, the qubchur was paid by villagers in two equal installments, at Nou Rūz and at the Autumn solstice, and by nomads only at Nou Rūz. ${ }^{119}$ In the North Caucasus, the qubchur, apart from being a cattle tax, was also a head (poll) tax, collected in coins or silk. Since these regions had no local coinage, this levy was assessed on livestock in the area. ${ }^{120}$ Qalan in Iran under Rashīd al-Dīn lost its original Mongol meaning of military duty, and was probably a levy of labour service. ${ }^{121}$ Taghar in Iran was a fodder or forage tax paid in grain, at a rate of 100 mans, which equalled one ass load. ${ }^{122}$

5. Ögedei Khan established the postal system (yams) throughout the empire to provide urgent dispatches of decrees, revenues and taxes. The arbitrary tax yam for the elchis/ìlchis (envoys, messengers) had been levied at the expense of provincial inhabitants. On this occasion, Kirakos Gandzakets'i says:

And then they [the Mongols] began to harass them [the Armenian princes] through taxation, by travelling to and fro, and by soldiership, and even more than this, they placed them under duress, but killed no-one. ${ }^{123}$

Hundreds of cavalrymen often accompanied the elchis. ${ }^{124}$ The passage of the envoys, and expenditure on their food and service were additional duties met by the local inhabitants. Kirakos continues

117 Juvaynī/Boyle, 1997:551.

118 Ibid., 524.

119 Lambton, 1953:80.

120 Allsen, 1987-1991:33.

121 Lambton, 1988:200. Qalan in Iran was used as the obligation to the ruler (Schurmann, 1956:334). Qalan and its Perso-Arabic substitute mal in the narrowest sense has a meaning of agriculture tax (Allsen, 1987:154).

122 Petrushevsky, 1968:533. Juvaynī/Boyle, 1997:609.

123 Kirakos Gandzakets‘i, 1961:263.

124 Lambton, 1953:82. 
that the Armenian prince Hasan Jalal prudently arranged his land and business for the needs of the Mongol travellers, who were coming to him, whether for food or something else; he made ready whatever he could to meet the needs of the Mongol elchis. ${ }^{125}$

6. In mentioning the tribute levied for postal couriers and their horses, the Armenian historians meant the levy called ulagha / ulägh. Ulagha existed in Mongolia until the beginning of the twentieth century and meant relay transportation. Various combinations of this term provided the Mongolian language a rich vocabulary, such as ulagha nekhekhu which meant to accompany someone travelling by relay in order to return the horses, or ulagha zar bichig that meant a travelling warrant for obtaining relay horses. ${ }^{126}$ The efficiency of couriers was a matter of special importance; therefore, in the territory of the Il-Khanate, ulagha was a tax levied at a certain constant rate every year. During the Mongol period, this tax was described by some Muslim sources as a 'national calamity.' ${ }^{127}$ The reason for such a definition may relate to the scarcity of horses available to maintain this duty in addition to the supply of horses for the army.

In addition to these taxes, during Mongol rule, there was another Mongol tax called susun or shusun (provision tax) found in the undated inscription of Shirakavan. ${ }^{128}$ There was one more tax of Mongol origin called nemeri/nemari, which in Mongolian means 'added' or 'associated.' This was an extraordinary tax abandoned by Abū Sa î̀ (r. 1316-1335) which was inscribed in one of his edicts in Ani. ${ }^{129}$

${ }^{125}$ Kirakos Gandzakets'i, 1961:269.

126 Tsevel, 1966:587; Lessing, 1973:869.

${ }^{127}$ Petrushevsky, 1968:536.

128 Kostaneants', 1913:247; Manandian, 1952:284.

129 The edict is written in Persian on the walls of Manuche mosque in Ani and has no date. Barthold suggests that the date of the inscription is between 1319 and 1335, probably towards the 1330s (Barthold, 1966:319). Babayan suggests the date as 1319 (Babayan, 1969:178). The text of the edict says that according to the order of the Il-Khan, except for the tamgha, all other unlawful taxes, such as qalan, nemeri, and tarkh should be abandoned in the city of Ani and other regions of Georgia (Barthold, 1966:318). The Persian text, reproduced by Alishan, reads the tax nemari نمارى as thamadi ثمادى with the translation left blank (Alishan, 1893:56). 
In connection with the taxes, it is worth mentioning about another Mongol term tarkhan (darkhan), ${ }^{130}$ which was also found in Armenian sources; it was either juridical document verifying tax immunity or a title given to a person who was exempt from taxation. ${ }^{131}$ In addition to the clergy, rich Armenian merchants were granted tarkhan documents, like Asil Umek, who lived first in Karin, then in Tiflis; or the sons of the wealthy houses of Saravan, Shnorkhavor and Mkrtich'. ${ }^{132}$

Many taxes of non-Mongol-origin are mentioned in the sources as well. ${ }^{133}$ The mal, which was a property or possession tax, was assessed by measurement. ${ }^{134}$ According to Babayan, the mal in Armenia evolved from a land tax to a possession tax because the land tax was replaced by the qalan. ${ }^{135} \mathrm{~A}$ certain portion of revenue from the mal was divided between the local landowner and the Mongol divan. ${ }^{136}$ Interestingly, the tax on vineyards and orchards in the Armenian inscription of Talin in 1267 and in Mren in 1273 was called the khalan. ${ }^{137}$ This surely was not related to the military tax qalan we described above, since in the inscriptions of Ani in 1036, this tax had already been mentioned. ${ }^{138}$ The Muslim agriculture and land tax known as kharaj was also levied in Armenia. ${ }^{139}$ In the account of the martyrdom of St. Grigor, Bishop of Karin, it is stated that, in addition to the poll tax of seven or eight dahekans (gold coins), people paid the kharaj from the age of 12. ${ }^{140}$ The 'alafa (fodder) and the 'ulufa (food) were arbitrary taxes imposed on local populations to host visiting messengers. ${ }^{141}$

Besides these taxes, the Armenian peasant had to continue to serve corvées to his lord or the clergy, since the main husbandry of the

${ }^{130}$ The tarkhan was exempted from obligations of tribute to his lord, and was given a certain degree of juridical immunity (Schurmann, 1956:323).

${ }^{131}$ In modern Mongolian, there are the expressions darkhan avraga, or champion of champions for wrestlers, and darkhan ber, or the daughter-in-law who gives birth to three sons successively, by which she obtains immunity for herself in the family of her husband.

${ }_{132}$ Kirakos Gandzakets'i, 1961:363; Orbelian, 1910:395.

133 Step'annos Orbelian, 1910:493; Grigor Aknerts'i, 1974:25.

${ }_{134}$ Lambton, 1988:358.

${ }_{135}$ Babayan, 1969:249.

136 Grekov, 1953:683.

137 Babayan, 1969:252.

${ }^{138}$ Kostaneants', 1913:20; Manandian, 1952:282.

139 On kharaj coinage, see Kolbas, 2006:180.

140 Ter-Davtyan, 1973:277.

141 Rashīd al-Dīn, 1946(Vol. 3):248. 
Armenians was based on labour rent. ${ }^{142}$ There were many other taxes, such as akhst'amar and kapal (commercial taxes), dŕnagir (tax imposed at the city gates), t'arkh (tribute to provide provisions for the army), kasanik (tax on artisans), aghlkak (tax on sheep), hazr ezin or hasara (tax on oxen), and hambrele (tax on cows), imposed in Armenia during the thirteenth and fourteenth centuries. ${ }^{143}$

Based on the above, it can be concluded that the Mongol tax system differed from that which existed in the sedentary societies of Armenia or Georgia before the Mongols' arrival. Mongol taxes imposed in Mongolia can mostly be classified into two major categories: tributes, levied on individuals or households and paid to their immediate lord (qalan, qubchur, taghar, tamgha); and corvées, imposed on individuals or households in order to permit the execution of some functions for the ruler or lord (ulagh, yam, nemeri).

With the establishment of Mongol rule, the taxes imposed in Armenia can be divided into four major categories: commercial taxes; land taxes; ${ }^{144}$ military corvées (occasional); and taxes with quotas set in currency, the revenues of which apparently went to the Court or the owners.

Modern scholars who are working on the fiscal system of the Mongols practised in different parts of the Mongol Empire are trying to make distinctions between tribute, levy and tax. ${ }^{145}$ This is a complicated issue but it is obvious that the Mongol taxation policy in the territories of the Il-Khanate, including Armenia, evolved from being an occasional tax based on census to a more systematic one. ${ }^{146}$

${ }^{142}$ For the main source for taxes levied in Armenia before the Mongol rule, see Mkhit'ar Gosh (1130/1140-1213).

${ }^{143}$ Manandian, 1952:281-283; Babayan, 1969:251-263.

144 From the second half of the thirteenth century, land categories within the IlKhanate were changed into divan or state land; enchü or private land, given to the ruling family and nobles; vaqf, land permanently given to clergy and religious institutions; milki or privately owned land, which could be sold and bought, inherited and presented; and iqta $\bar{a}^{-}$or the military fief. In the Il-Khanate, the majority of military iqțā were in Azerbaijan: Namely in Shirvan and Gushtāsfī (the lower reaches of the rivers Kur and Arax). Gushtāsfī had an irrigation network over fields and villages. The Pīshkin district was under iqtāà, the annual revenue of which was 50,000 dīnārs, while the revenue from other districts was only 5,000 dīnārs (Qazvīnī, 1915:382, 392-396). For the iqțā system in the Islamic Middle East, see Amitai, 2001:152-171.

${ }_{145}$ For Mongol taxation, see Grekov, 1953:679-685; Lambton, 1953, 1986-1988; Smith, 1970:46-85; Sinclair, 2000:39-52.

${ }_{146}$ If the Mongol fiscal obligations in China during the Yüan Empire and in Iran after the Ghazan Khan's updated tax reform brought a unified system to these states, it did not happen in Russia (the Golden Horde) (Schurmann, 1956:309). 
A system of dual taxation existed: The Mongols levied their taxes in addition to the existing ones. The exhaustive list of taxes mentioned randomly in the Armenian sources is concluded by some of them as follows:

From those who had nothing to give, they took their sons and daughters according to demand. ${ }^{147}$

Kirakos Gandzakets'i reports that artisans, anglers, miners and manufacturers were heavily taxed. ${ }^{148}$ As has been said earlier, increased Mongol and local taxation in 1245-1246, drove some nobles from their lands and made them flee to fortresses. ${ }^{149}$ This severe taxation policy was one of the reasons for the Georgio-Armenian princes' rebellion of $1249 . .^{150}$ The Mongol tax qubchur introduced in 12591260 was a cause not only for rebellion by the Caucasian lords, but also for mortgaging their estates to pay this tax. ${ }^{151}$ The salt mine in Koghb province was a very profitable business for the Mongols probably due to the high tax on salt. ${ }^{152}$ In 1261 , some of the lords were killed because of their failure to pay tax. ${ }^{153}$ As a result of the general census in Greater Armenia taken in 1275, all tax privileges were revoked and taxes were now levied not on the household, as before, but by head, by size of property, and on cattle as well. ${ }^{154}$

Without claiming that Mongol administrative measures, introduced in Greater Armenia were systematic and that the various terminologies were fully consistent for this whole period, this chapter listed the variety of taxes levied in Greater Armenia alone because no such evidence can be found in the contemporary sources for Cilician Armenia. The Mongol period was in many ways a disaster in Greater Armenia because the control of all economic resources was the Mongols' priority. However, they were aware that, without maintaining proper economical bases, they would not have any means to sustain the conquered territories. Therefore, the reforms of Möngke Khan in 1254 aimed to stop illegal taxation by the governors

${ }^{147}$ Kirakos Gandzakets'i, 1961:374-375.

${ }^{148}$ Ibid., 362-363.

${ }^{149}$ Ibid., 266, 313, 319.

${ }_{150}$ Grigor Aknerts'i, 1974:35; Kirakos Gandzakets'i, 1961:312-314; Melikset-bek, 1936:56.

${ }^{151}$ Kirakos Gandzakets i, 1961:362.

152 Ibid., 363.

153 Vardan Arevelts'i, 1991:152; Kirakos Gandzakets'i, 1961:390-391.

${ }^{154}$ Garsoïan, 1997:128. 
and princes for their personal aggrandisement. The Khan knew that numerous taxes might cause tax-paying subjects to escape and thus ruin the imperial economy. ${ }^{155}$ Although his policy brought order, the nature of the taxes was not altered.

The occasional taxes of a nomadic society that were extended to sedentary societies underwent some modifications. The new fiscal system comprised both traditional fiscal obligations and Mongol tributes. ${ }^{156}$ This made it easy for the two systems to exist side by side, and in fact, this double system was a heavy burden on the conquered population. ${ }^{157}$ The introduction of the Mongol fiscal administration in Armenia made possible a change in the political status of Armenia from a vilayet to an administrative province of the Il-Khanate.

The exhaustive list of Mongol and local taxes suggests that the taxation issue was a primary concern for the Greater Armenians. As the Mongol period progressed, tributes increased and this is reflected in the Armenian sources, from which the overall picture of the nature of Mongol administration is taken. A detailed classification of all tax terms and terminologies that evolved over the Il-Khanid period would require a comparison with other regions of the empire, something which cannot be undertaken here. Nevertheless, the evidence provided by the Armenian sources should be a useful addition to the detailed studies provided, for example, for the province of Fars in southern Iran. ${ }^{158}$

The hardship imposed on Greater Armenia by the Mongols can be contrasted with the much more favourable situation enjoyed by Cilician Armenia. Regardless of these, both Armenias participated in the Mongol conquest of the Middle East.

155 Allsen, 1987:144.

156 On the evolution of the Mongol revenue system, see Allsen, 1987:144-188; Schurmann, 1956:376.

157 Lambton, 1986:84.

${ }^{158}$ Lambton. 1986/1987; Aigle, 1997. 


\section{MONGOL-ARMENIAN MILITARY COOPERATION: STAGE I: THE CONQUEST OF THE MIDDLE EAST (1258-1260)}

As has been said earlier, during his journey to Mongolia in 1253/1254, the Armenian King Het'um agreed to ally with the Mongol Empire and submitted the Mongol Great Khan. The implementation of this agreement occurred only when the Chinggisid lineage imposed its own supremacy, later known as the Il-Khanate, over the Caucasus, Asia Minor, Iran and Upper Mesopotamia after 1256.

The main allies of this campaign were King Het'um from Cilicia, the Greater Armenian lords under the Georgian King David Ulu and the Mongol Prince Hülegü, ${ }^{1}$ who promoted himself as a founder of the Mongol dynasty in this region. Hülegü aimed to restrain the two independent powers of the eastern Islamic world: The principality of the Ismāî̀i imams in Māzandarān (Țabaristān)2 and the 'Abbasid Caliphate of Baghdad. This move against these Islamic powers perfectly suited the Armenians' wishes. The timing was appropriate; although there were several local politically-influential dynasties in Persia and Syria, there was no centralised power in that region at

${ }^{1}$ Hülegü was the fifth son of Tolui Khan by his chief wife Sorqoqtani Beki. Tolui Khan, known as Ulugh-Noyan in Muslim sources, was otchigin (the youngest) of the chief sons of Chinggis Khan. He was a great winner of battles, for no princes conquered as many lands as he did, some alongside his father, including Bukhara, Samarqand, Badakhshan, Khurasan, Merv, Maruchuq, Sarakhs, Nishapur, Quhistan and Herat (Rashīd al-Dīn, 1971:163-165). He died from illness in the campaign against the Jürchen-Chin in 1232 (MNT, 2004:95-96[\$272]). Sorqaqtani Beki gave her orphaned children an education not only in good manners, but also in army training (Rashīd al-Dīn, 1971:168-169). Two of her sons, Möngke (r. 1251-1259) and Qubilai (r. 1260-1294) became the Great Khans and her son Hülegü (r. 12561265) became the first Il-Khan. The senior wife of Hülegü was Doquz (Toghuz) Khatun, who had previously been a wife of Tolui. She was a powerful woman who was held in great respect. Since she was from the Nestorian Kereit tribe, she constantly supported the Christians. For Doquz Khatun, see Spuler, 1972:121-122; Melville, 1996c:475-476. Hülegü allowed her to build churches and to carry a movable church-tent within her camp (Rashīd al-Dīn, 1954:678). She saved many Christians from death during the sack of Baghdad.

2 The Ismāîlīis maintained a strong state of their own from $483 \mathrm{H}$. (1090) to 654 H. (1256) (Hodgson in Boyle, 1968:422). 
that time. ${ }^{3}$ Therefore, these two Islamic regimes became the target for the Mongols after they had extended their power into the territories of the Seljuk Sultanate of Rūm, as the result of their victory at Köse Dagh. However, Hülegü decided to advance further and conquer Syria and Egypt. The achievement of Hülegü as a conqueror follows along with the narrative in what way Mongol-Armenian cooperation was carried on.

Hülegü (r. 1256-1265) and the Greater Armenian Forces against the Muslim Supremacies

At the end of 1256, Prince Hülegü of the Chinggisid lineage came to govern Iran, Rūm and the Caucasus. The initial assistance that Hülegü received from the Armenian lords occurred during his confrontation with the Ismāi îlīs. ${ }^{4}$ In 1256, David VII Ulu, the King of Georgia (r. 1247-1270) with Armenian and Georgian auxiliaries took part in the Mongol conquest of Alamut. ${ }^{5}$

\section{Armenian Provision of Aid to the Mongols}

In 1251, Baiju Noyan, who was a supreme Mongol figure in Iran, the Caucasus and Anatolia, made complaints about the Ismāîlīs and about the Caliph of Baghdad to Güyük's first cousin and successor Möngke Khan. ${ }^{6}$ This information given by Rashīd al-Dīn is supported by Kirakos Gandzakets'i, who, in his Patmut'iwn Hayots (History of the Armenians), states that the Ismā'îlīs killed Chaghatai Noyan, one of the Mongol generals in Armenia and a friend of Awag Zak'arian in the 1240 s. $^{7}$

${ }^{3}$ Morgan, 1990:145.

4 The Ismāîlīs were a branch of the Shīî sect of Islam, a radical sect and one of the main divisions of the Muslim faith from the tenth century. At the end of the eleventh century and the beginning of the twelfth, the members of this sect in Syria and Iran had been driven from the cities and had taken refuge in the mountains of northern Syria and northern Iran. In Iran, they had established a series of castles on rugged peaks in remote areas. Their defence was secured by fortifying themselves in remote mountains and by the use of suicide assassins to dispose of enemy leaders (Kennedy, 2002:164).

${ }^{5}$ Mkhit'ar Ayrivanets'i, 1860:67.

${ }^{6}$ Rashìd al-Din, 1954:684. Based on the complaints of Shiramun, the son of Chormaghan, Güyük had previously expressed his disappointment to the Caliph Ambassador (Rashīd al-Dīn, 1954:570).

7 Kirakos Gandzakets'i, 1961:264, 275. For Chaghatai Noyan and Awag Zakarian, see Chapters 2 and 3. 
Information about the Ismāîlīs reveals that there was both a diplomatic and military relationship between the Mongol khans and the Ismā îli leaders from the early decades of the thirteenth century; emissaries of Imām Jalāl al-Dīn Hasan (1210-1221) visited Chinggiz Khan to express their goodwill as early as $1219 . .^{8}$ This probably explains why, during the first Mongol invasions of Khurasan in 1220-1221, the Mongol force did not raid the region of Kūhistān and many refugees, including Nașīr al-Dīn al-Ṭūsī (1201-74) found shelter there. ${ }^{9}$ In 1246, 'Alā al-Dīn Muhammad (r. 1221-1255) dispatched another mission, led by two senior Ismā îli $d \bar{a}$ ' $\bar{s}$ (missionaries), to Güyük Khan for the occasion of his enthronement ceremony. ${ }^{10}$ But, by that time, something had changed in the Mongol attitude towards the Ismāiliss, the real cause of which is not clear. It is only known that, as Rashīd al-Dīn attests, Güyük gave a very angry reply to the letter brought by the ambassadors of Alamut, and he dispatched reinforcements to the Mongol armies already stationed there, with instructions to reduce Muslim forts, beginning with the Ismāîlīs. ${ }^{11}$ Güyük intended to follow afterwards but his death prevented him.

The relationship of the Ismāi îlis with the Mongols deteriorated as a result of complaints about the military and political activities of the Ismāîlis in the region. These complaints were received at the Mongol court not only from Mongol commanders, but also from 'ulama', the Sunni scholars. ${ }^{12}$ In addition, there was a direct threat from the Ismā'îlis in Mongolia. In his travel record, Friar Rubruck mentions 400 assassins who arrived at the court of Möngke Khan under various disguises with the purpose of killing the Khan. ${ }^{13}$

\footnotetext{
${ }^{8}$ Juvayni, 1962:248; Jamal, 2002:45. From the very moment of his accession, the Ismāīîi Imām Jalāl al-Dīn Hasan professed Islam and strictly forbade his people from adhering to the heresy urging them to follow the rites of the Shari'a. He became known as Jalāl al-Dīn the Neo-Muslim (Juvaynī, 1962:243).

${ }^{9}$ May, 2004:233. On Nașir al-Dīn al-Ṭūsī and the Ismāî̀līs, see Dabashi, 1996:231-245.

${ }^{10}$ Juvaynī, 1962:205; Daftary, 1998:150.

${ }^{11}$ Rashīd al-Dīn, 1954:50, 570

12 Jamal, 2002:46.

13 Dawson, 1955:184; Morgan, 1990:148; Rubruck, 1990:222. The number 400 seems to be a symbolic number. Besides this, as Jūzjānī recounts, all the people of the city of Qazvīn made great preparations for warfare with the Ismā îlīs of Alamut, due to daily conflicts that were taking place between the Qazvīnīs and the Ismāîlīis. Qãzị Shams al-Dīn Qazvīnī, the sincere Imām, according to Jūzjānī, who attended Güyük
} 
One can find the same notion in the Zafar-Näma (ca. 1335) of Mustawfì Qazvīnī, where the Qāẓi from Qazvin warns of the danger from the Ismāi ìlis at Möngke Khan's court. Moreover, according to Mustawfī Qazvīnī, the choice of Hülegü to be sent to Iran was approved by the Qāzị. ${ }^{14}$ It is uncertain whether the Qāẓ̂ had such an influence on the Mongol court. This is surely a later interpretation; however, the source speaks for the close relationship between the two parties.

Indeed, Möngke Khan recognised that the Ismāîlīs might pose a serious threat to the trade routes and communication. He also realised that there were lands nearby in Iran conquered during the time of Chinggis Khan and not yet belonging to him. Therefore, according to Rashīd al-Dīn, he decided to allot these lands to his brother Hülegü, who was expected completely to subjugate Iran, Syria, Rūm and Armenia. ${ }^{15}$ Hülegü was also dispatched to put an end to the provisional regime of Mongol military rule and fiscal administration in the region. ${ }^{16}$

According to Juvaynī, Hülegü set out 'from Qara-Qorum against the Heretics into the land of the Tajjiks in the year of the Ox (1253). ${ }^{{ }^{17}}$ Hülegü did not reach Iran before the beginning of $1256^{18}$ but he had dispatched in advance an army of 12,000 men from Mongolia in 1252 under the command of Ket-Buqa of the Naiman tribe, the Nestorian Christian, to join the Mongol garrisons already camping in Iran. ${ }^{19}$ Ket-Buqa crossed the Oxus in 1253 and the initial confrontation between the Mongols and the Ismā îlis occurred in Kühistān when

Khan's coronation ceremony, travelled several times to Mongolia, until the time of Möngke Khan, to obtain aid in his fight with the Ismāî̀īs (Jūzjānī, 1970:1189).

${ }_{14}^{14}$ Qazvīnī, 1999:1118-1120; Lane, 2003:16.

${ }^{15}$ Hülegü was instructed to apply the law of Chinggis Khan in the territories between the Amu Darya and Egypt (Rashīd al-Dīn, 1954:685).

${ }^{16}$ Ibid., 686.

${ }^{17}$ He was accompanied by two of Jochi's grandsons, Balaghai and Quli, and one of his great-grandsons, Tutar (and by one of Chaghatai's grandsons, Tegüder) (Rashīd al-Dīn, 1954:707; Juvaynī/Boyle, 1962:91). Möngke Khan also sent another brother, Qubilai, to consolidate Mongol conquests in China including Khitai, Machin, Karajang, Tangqut, Tibet, Jurje, Solanga, Gaoli and a part of Hindustan. Qubilai later became a founder of the Yüan dynasty in China and succeeded Möngke as Great Khan (Rashīd al-Dīn, 1954:685; Boyle, 1968:340).

${ }_{18}$ Exercising his seniority among the Chinggisids, Batu Khan forbade Hülegü from crossing the Oxus River (Amu Darya); only after the death of Batu in 1255, did Hülegü move towards Iran (Trepavlov, 1993:81).

${ }_{19}$ Ket-Buqa Noyan had the rank of ba'urchi (Rashīd al-Dīn, 1954:686; Juvaynī, 1962:95). The ba'urchi, I believe, was a Mongol officer in charge of food safety for the Great Khans, rather than a simple cook/steward. 
Ket-Buqa attacked several Ismāi îlī strongholds, putting their inhabitants to the sword before laying siege to Girdkūh castle. ${ }^{20}$

In 1256, Hülegü came to Iran through the Chaghatai Ulus, ${ }^{21}$ crossing the Amu Darya and passing the eastern borders of Transoxiana, Herat and Kūhistān. ${ }^{22}$ On his arrival at the Persian bank of the Amu Darya, news about him coming to destroy the Ismāîlīs was spread to the Lords of Rūm, Fars, Iraq, Azerbaijan, Arran, Shirvan and Georgia. All of them came to him with many gifts to acknowledge their services. ${ }^{23}$ Since Georgia was named, it is understood that the Armenian princes did the same.

According to the Armenian sources that confirm the picture given by the Persian historian it is understood that the actions against the Ismāîlīs were unavoidable. The reference given in the Chronicle of Smbat Sparapet, states that in the year 702 (1253), when King Het'um I went east to Möngke Khan, he had to dress as a cattle driver in order to pass through the lands of the Ismā îlis in Cappadocia. ${ }^{24}$ Kirakos Gandzakets'i gives an interesting account of the Ismāi îlis or Mulheds: $:^{25}$

There was a nobleman, called Orghan ... who was killed in Gandzak by the Mulheds [heretics], who were accustomed to kill people secretively. Some people approached him [Orghan] while he was walking on the street, as if someone had threatened them and they approached him for justice. Having a piece of paper in their hands they showed it to him, shouting and begging: 'Justice, justice!' When he [Orghan] stopped and wanted to inquire about who had assaulted them, they jumped upon him from here and there, and with the sword which they had concealed, stabbed and killed him ... They killed many people and fled through the city, because this nation was accustomed to behaving in such a way. They encroached upon the fortified places called T'un and $\mathrm{T}^{\prime}$ anjak as well as the forests of Lebanon, taking their blood-price from their prince, whom they worshipped instead of God ... They went many times wherever their prince sent them being frequently in various

${ }^{20}$ Boyle, 1968:341. Girdkūh only surrendered after about 20 years in 1271 in Abaqa Khan's time (Rashīd al-Dīn, 1954:766).

${ }^{21}$ The territories north of the Pamir and T'en Shan mountains, held by Chaghatai, the second son of Chinggis Khan (Manz, 1999:4).

${ }^{22}$ Juvaynī/Boyle, 1997:612-618. According to Baiḍāwī, Hülegü spent the winter in Khurasan, and then he set off for Kūhistan (Melville, 2007:52-58).

${ }^{23}$ Rashīd al-Dīn, 1954:688.

${ }^{24}$ Smbat Sparapet in Galstyan, 1962:49.

${ }_{25}$ Being regarded as a heretical sect of Islam, the Ismāîliss were referred to as Mlheds ( $\left.V_{L} h h_{i}\right)$ [mulhids] by Vardan Arevelts'i, 1991:149, and Hashishik' (Zuchichf) by Het'um Patmich', 1956:70. 
disguises until they found the appropriate moment to strike and then to kill whomever they wanted. Therefore all the princes and kings feared them and paid tax to them. And they [the Ismāi ìis] strictly followed the orders of their prince and did whatever he said, even to commit suicide. Thus, they killed many dignitaries who did not pay them tax, as well as killing this impious man [Orghan]. ${ }^{26}$

This extract may explain why the Armenians were later involved in the Mongol fight against the Ismāi ilis, as they were the main providers of foodstuffs for the Mongol armies. ${ }^{27}$ When messengers were sent to all subjugated lands to procure food for the Mongol army and its horses, it was decided to transport provisions from Armenia to Yazd. Everyone in these territories without exception was forced to pay the food levies of ulagh and taghar, ${ }^{28}$ even in Greater Armenia when the whole country faced a severe famine in $1256 .{ }^{29}$ It seems that in addition to the political reasoning, there was an economic reason why the Armenians were interested in the elimination of Ismāî̀ì power.

The Mongol model of siege tactics and negotiations led to the defeat of the Ismâ îlis. ${ }^{30}$ It was on 19 November 1256 when the last of the Ismāî̀ì imams, Rukn al-Dīn, submitted ${ }^{31}$ and Hülegü's victory was recognised as a great service to orthodox Islam. ${ }^{32}$ It is noted by Bar Hebraeus as follows:

And by means of these blessed captures God had mercy on all the kings of the Arabs and Christians who lived in terror and trembling through the fear of the Ishmaelites who were carriers of daggers and were shedders of innocent blood. ${ }^{33}$

After his victory over the Ismāîlīs, Hülegü decided to live in the Mughan plain that had previously been occupied by Baiju Noyan;

${ }^{26}$ Kirakos Gandzakets'i, 1961:226-228.

27 Rashīd al-Dīn, 1954:695.

${ }^{28}$ Juvayni//Boyle, 1962:112. For the ulagh and taghar, see Chapter 4.

${ }^{29}$ Sebastats'i in Hakobyan, 1956:142.

${ }^{30}$ On the pattern of Mongol tactics, see Chapter 2.

31 Juvaynī/Boyle, 1962:133. The Syrian Ismāìlīs escaped Mongol rage; some Ismāîlīis remained in Iran and fled to India in the nineteenth century, establishing there the seat of the Nizārī Ismā îlì imamate. Their ultimate successor, the Aga Khan, is still the head of the sect (Daftary, 1998:4; Morgan, 1990:151).

${ }^{32}$ Boyle, 1968:345. In the eleventh century, Sunnī scholars began to establish orthodox colleges, madrasas, to rival the Ismā îli mission schools organised in Cairo and elsewhere. The madrasa system was extended to Baghdad and later to Egypt (Lewis in Hussey, 1966:658-659).

${ }^{33}$ Bar Hebraeus, 2003:423. 
therefore, Hülegü ordered Baiju to move to the inner lands of Rūm (in Bithynia), vacating Caucasian Albania, Georgia and Armenia for himself. ${ }^{34}$ According to Vardan Arevelts'i, the Armenians and the Georgian King David welcomed Hülegü. ${ }^{35}$ The replacement of Baiju by Hülegü and thus the shift of Baiju's base from Mughan was a strategic change in the nature of Mongol rule in the region. It was the beginning of the formation of a new Mongol state to be known as the Il-Khanate. Being of direct Chinggisid lineage, Hülegü took control and supremacy over the Mongol noyans stationed in Rūm, Iran, Afghanistan and the Caucasus. According to Grigor Aknerts'i, after the victory over the 'Abbāsid Caliph, Hülegü dispatched his envoys to the Great Khan Mönkge to ask for his next orders. Mönkge Khan sent back his judges to install Hülegü as a Khan of that land. When the messengers reached Hülegü, they convened a quriltai, or assembly, to which all the noyans stationed in the region were invited. Some of them submitted to the command of Hülegü, while some refused. ${ }^{36}$ Hülegü's next move was directed against the 'Abbasid Caliphate of Baghdad, a domain of Sunnite Islam in 'Irāq-i 'Arab, to the accomplishment of which the Armenian lords contributed greatly.

\section{An Armenian Envoy Sent to the Caliph}

Rubruck states in his account that he saw the ambassador of the Caliph of Baghdad at the court of Möngke-Khan. However, according to Rubruck's narration, two contradictory accounts are given to explain the Caliph's ambassador's presence in Qara-Qorum. First, Rubruck was told that the Caliph of Baghdad had made peace with the Mongols, and the ambassador was to give 10,000 horses to the Mongol Army. ${ }^{37}$ Second, Mönkge Khan refused to make peace unless the 'Abbasid Caliph destroyed his fortresses, to which the ambassador replied: 'When you remove all your horses' hooves, we shall

${ }^{34}$ Kirakos Gandzakets'i, 1961:374; Bar Hebraeus, 2003:424-425. Baiju was ordered to move west into the territories of the Seljuk Sultanate of Rūm which were disputed between the two sons of Kay-Khusraw II. Since 'Izz al-Dīn Kaykā'ūs (Kay Kāwūs) was defeated by the Mongols at Aqsaray in 1256, his younger brother, Rukn al-Dīn Qilich (Kilıc) Arslan was recognized as ruler (Cahen, 2001:184-186).

${ }^{35}$ Vardan Arevelts'i, 1991:149.

${ }^{36}$ Grigor Aknerts'i, 1974:44. No similar reference is found in Persian sources, allowing the Armenian source to consider a justification of Hülegü's rulership.

37 Rubruck in Komroff, 1989:187; Rubruck, 1990:247. 
destroy all our fortifications. ${ }^{38}$ Based on these two statements, one can assume firstly that Rubruck had visited Mongolia during 12531255 and, secondly, that there were contacts between Mongolia and the Caliphate of Baghdad while peace prevailed. Nevertheless, the character of this relationship changed towards hostility due to the expansion of Mongol power from Iran into Iraq. If we believe the Secret History of the Mongols, the conquest of Baghdad was set up as early as 1221 during the time of Chinggis Khan when he was stationed in Tālighān, and Chormaghan and other commanders suggested bringing down the "Abbasid Caliphate. ${ }^{39}$ This idea was carried through the reigns of the succeeding three Great Khans and was implemented only in the time of Hülegü.

Nonetheless, there is an alternative scholarly view on this matter, where the Mongol move against Baghdad connected with the ambition of Hülegü, who wished to consolidate the Middle East under Mongol control. Hülegü's anger may have turned the Mongols against the 'Abbasid Caliphate, when the latter refused to send troops to assist the Mongol fight against Ismā îli power. ${ }^{40}$ This opinion seems not to be well founded for two reasons. Firstly, it disregards the Mongols' plan of 1221 and, secondly, it devolves responsibility for the whole conquest of Baghdad solely to one person's anger or ambition. It is worth remembering that, in the mid-1250s, the central court of the Mongol Empire was still in charge of peripheral business and that the ideas conceived by Chinggis Khan were carried forward.

Detailed information on the stages of the Mongol advance to Baghdad is found in a Persian chronicle, which states that from September 1257 onwards, Hülegü and Caliph Musta'șim (r. 12421258) exchanged several messages in which the Caliph refused to accept the Mongols' warning and to hand over his domain. ${ }^{41}$ Hülegü established contact with the Caliph's governor of Dartang and the commander Ket-Buqa persuaded him to hand over the castles in his area. By this action, Ket-Buqa secured his passage through the Zagros Mountains. ${ }^{42}$

\footnotetext{
${ }^{38}$ Ibid., 247.

${ }^{39}$ MNT, 2004:91(\$260); SHM, 2001:252.

40 Amitai-Preiss, 2004:16.

${ }^{41}$ Rashīd al-Dīn, 1954:699-705.

${ }^{42}$ Ibid., 705-707.
} 
In November 1257, Hülegü set off from Hamadān in the direction of Baghdad. He was accompanied by two of Jochi's grandsons, Balaghai and Quli, one great-grandson, Tutar, and by one of Chaghatai's grandsons, Tegüder. ${ }^{43}$ Since Baghdad shared a common border with Mosul and knowing that Badr al-Dinn Lu'lu', the atabeg of Mosul, who had already supported the Mongols, would assist him, Baiju came from Anatolia to the west bank of the Tigris by the Mosul road. ${ }^{44}$ With him were the forces of the Armenian Prince Zak'arē, the son of Shahnshah Zak'arian and Prince Pŕosh Khaghbakian..$^{45}$ The Mongols placed considerable trust in these Armenian lords, whose assistance they had received since the 1230s. The right flank of Hülegü, commanded by Generals Balaghai, Tutar and Quli advanced through Shahrazūr and Daqūqā. Kit-Buqa commanded the left wing coming by way of Luristān and Khūzistan. The centre under Hülegü came down via Kirmānshāhān and Hulwān. ${ }^{46}$ The Mongol armies converged on Baghdad in January 1258. Caliph Musta șim still hoped that he could successfully trick the Mongols as his predecessors had done for more than 500 years with the Būyids, Seljuks, Khwārazmians and others who had infringed upon their dominions. ${ }^{47}$

As usual, Hülegü sent an emissary to the Caliph asking for obedience. According to Kirakos Gandzakets'i, the Armenian Prince Prosh Khaghbakian was entrusted with the very important role of leading this emissary. ${ }^{48}$ It is not known on what grounds he was selected to be the ambassador. Unfortunately, the delegation received a reply full of insults, on receipt of which the Mongols surrounded the Caliph's army. The davāt-dār (chief secretary) who commanded the Caliph's army was encamped between Ba'qūbā and Bājisrā. Hearing that the Mongol army was approaching from the west, the davāt-dār crossed the Tigris and joined battle with the Mongols near Anbār. ${ }^{49}$ The Mongols retreated and, joining Baiju's main army,

${ }^{43}$ Ibid., 707. The death of the first three princes would cause Hülegü a very high price: War with the Golden Horde.

${ }^{44}$ Badr al-Dīn Lu'lu' was obliged to supply provisions, weapons and a bridge of boats over which Baiju's army crossed the Tigris (Patton, 1991:60).

${ }^{45}$ Kirakos Gandzakets'i, 1961:380.

${ }^{46}$ Rashīd al-Dīn, 1954:707.

${ }^{47}$ Ibid., 700.

${ }^{48}$ Kirakos Gandzakets'i, 1961:380. Pŕosh Khaghbakian was a lord of the Khaghbakian or Pŕoshian House in Urkghunk', Boloraberd, Eghegiats' Dzor and Hrashk'aberd from 1223 to 1284 (Babayan, 1976:549).

${ }^{49}$ Kirakos Gandzakets'i mentions that the Dawdar (davāt-dār) at first was victorious, killing some 3,000 Mongols and sending messengers to the Caliph following 
opened a canal on the river Tigris. Half of the Caliph's army was drowned and half was defeated in the attacks that followed. ${ }^{50}$ The davāt-dār made an attempt to escape by boat down the Tigris. Being unsuccessful, he fled back to Baghdad. When the Caliph heard about this, he sent his Shi' ite vizier to soothe Hülegü. However, it was useless. The Mongols had already attacked the whole of the eastern fortifications of Baghdad. On 10 February, the Caliph came to Hülegü in person along with all three of his sons to surrender. ${ }^{51}$ The sack of Baghdad lasted seven days (from February 13 to 20), and during which the population of several thousands was massacred. ${ }^{52}$ With the help of Doquz Khatun, Hülegü's Nestorian wife, many Christians were spared during the devastation of Baghdad in $1258 .{ }^{53}$ The destruction of the Sunnī Caliphate in Baghdad was a great advantage for Shì 'issm, and the sparing of Shī'as in 1258 was due to the presence of a Shīîi theologian, Nașīr al-Dīn Țūsī. ${ }^{54}$

\section{The Armenian Account of the Fall of Baghdad}

The History of Kirakos Gandzakets'i gives a detailed account of the fall of Baghdad..$^{55}$ Gandzaketsi's source was Prince Prosh Khaghbakian, a participant and eyewitness of the conquest. ${ }^{56}$ The Armenian historian traces several points in the Mongol victory over the 'Abbasid Caliphate. First, he says that Hülegü ventured against the Caliph with an army of multinational subjects. ${ }^{57}$ Secondly, he states that the

his triumph (Kirakos Gandzakets'i, 1961:379).

${ }^{50}$ Because the Caliph's troops were encamped on low-lying ground, the Mongols made a breach in the banks of the river so that water poured down on the enemy at midnight (Bar Hebraeus, 2003:430).

${ }^{51}$ Rashīd al-Dīn, 1954:712.

52 Ibid., 712-713. The number involved in the massacre varies in Muslim sources. Some give 800,000 (Morgan, 1990:151). In Hűlegü's letter to King Louis IX of France, the Il-Khan gives the number of casualties in Baghdad as 200,000 (Meyvaert, 1980:256). All these numbers are highly unreliable.

${ }^{53}$ Vardan Arevelts'i, 1991:150; Kirakos Gandzakets'i, 1961:382. For Doquz Khatun, see Melville, 1996c:475-476; cf. Jackson, 2003:200-201.

${ }^{54}$ Boyle, 1968:538-539.

55 Kirakos Gandzakets'i, 1961:377-384.

${ }_{56}$ Pŕosh (Hasan) Khaghbakian himself told Kirakos Gandzakets'i about events surrounding the capture of Baghdad (Kirakos Gandzakets' $i$, 1961:384).

${ }^{57} \mathrm{Ibid} ., 378$. A military levy of two out of ten men was imposed by the Mongols in Armenia and Georgia, so obviously contingents of Hülegü's force were composed of multinational recruits as Kirakos Gandzakets'i states. For the military levy, see Chapter 4 (Martinez, 1986/1988:129-242). Juvaynī states that even earlier, the Turks 
Mongol Prince planned his raid on Baghdad very carefully, examining the location of the city. Certainly, Hülegü saw that there was only one route that would give the Caliph of Baghdad a chance to flee: The great river Tigris. Therefore, he sent Baiju who was stationed in Rùm to guard all possible exits to the river. In executing Hülegü's order, Baiju constructed a floating bridge across the river and sank sturdy nets with iron hooks and pipes into the water so that no one could swim through to freedom. ${ }^{58}$ Next, Kirakos Gandzakets'i describes how Hülegü reacted to the boastful words of the Caliph, who called him a 'Turkic dog,' by ordering the demolition of the city walls. Then, when the walls were demolished, he gave an order to rebuild them. ${ }^{59}$ This act perhaps does not correspond to reality, but it signifies the destiny of Baghdad, together with Hülegü's superiority. Another aspect of Kirakos Gandzakets'i's narration deals with the deaths of the two sons of Caliph Musta șim: Hülegü's son slew one, while the other one was given as a sacrifice to the river Tigris. ${ }^{60}$ The most fascinating point of this source is that the Armenian historian records how Hülegü killed the Caliph himself with his own hands, so giving us another version of the Caliph's death. ${ }^{61}$ Kirakos' narration is not supported by other sources, although he gives as his own source Pŕosh Khaghbakian, an actual participant in this event. As Boyle asserts, the last day of the 'Abbāsid Caliph is reported differently in different sources, whether Muslim or Christian. ${ }^{62}$ Based on the account attributed to Nașīr al-Dịn Țūsī, the story that is repeated by Marco Polo, Joinville, Het'um and others relates how the Caliph Musta șim was shut in the tower with his treasure and starved to death. ${ }^{63}$ According to Grigor Aknerts'i, the Caliph was trampled under the feet of the Mongol troops and this was how Hülegü slew him. ${ }^{64}$ Rashīd al-Dīn states that on 20 February 1258, in the village

and Tajiks were ready to join Hülegü's troops in attacks on the Ismāîlī castles (Juvaynī/Boyle, 1962:102).

${ }^{58}$ Kirakos Gandzakets'i, 1961:379.

59 Ibid., 380.

${ }^{60}$ Kirakos Gandzakets'i, 1961:382. According to Rashīd al-Dīn, the youngest son of the Caliph was given to Öljei-Khatun, the wife of Hülegü. In Maragha, the Caliph's son married a Mongol girl and had two sons by her (Rashīd al-Dīn, 1954:714). The Caliph's other sons were killed two days after their father's death (Jūzjānī, 1970:1254(note 4).

${ }^{61}$ Kirakos Gandzakets'i, 1961:381.

62 Boyle, 1961:149.

${ }^{63}$ Marco Polo in Komroff, 2003:32; Boyle, 1961:146, 148.

${ }^{64}$ Grigor Aknerts'i, 1974:42; Sykes, 1930:96. 
of Waqaf, the Caliph was put to death along with his eldest son and five servants, but gives no specific description of the execution. ${ }^{65}$ According to Jūzjānī, the Caliph was rolled up in a carpet, trampled upon by horses and kicked to death. ${ }^{66}$ As this was the customary Mongol form of execution to prevent the shedding of the dignitaries' blood, this last account commonly followed by Western scholars. ${ }^{67}$

After accomplishing his task, Hülegü himself withdrew northwards, first to his ordu (headquarters) near Hamadān, and then into Azerbaijan. ${ }^{68}$ But before this, in order to maintain city life, the vizier and the șahib-diviann were both re-established in their offices on the same day as the Caliph's death. ${ }^{69}$ Hülegü also appointed other officers to collaborate with them and sent two noyans with 3,000 cavalrymen to rebuild Baghdad, to bury the dead, restore the mosque and tombs, and rebuild bazaars. ${ }^{70}$ Buqa-Temür was dispatched to complete the conquest of southern 'Irāq-i 'Arab and Khūzistan.

\section{The Mongol Penetration into Upper Mesopotamia}

The task apparently set by the court of the Great Khan was completed. The Ismāîlì and the 'Abbasid powers were subjugated. However, Hülegü continued his world-conquering programme. It is interesting to speculate about the reason why the Mongols were drawn into Syria and Palestine. There can be many reasons, such as that the war machine could not be stopped as the procurement of new lands occupied the army; alternatively, the concept of the liberation of the Holy Land attracted the Mongols. Another reason is that the Mongols saw a chance to fill the power-vacuum of this region, disputed as it was between the Christian and Muslim worlds, or even within the Muslim world between the Ayyubid princes and the new Mamluk (Mamlūk) state in Egypt. Modern scholarship is still working to elaborate the causes of the Mongols' penetration of Syria. ${ }^{71} \mathrm{We}$ might note that the Mongol Empire was still in it expansionist phase and naturally sought to follow one conquest with the next.

\footnotetext{
65 Rashīd al-Dīn, 1954:713.

66 Jūzjānī, 1970:1252-1253.

67 Boyle, 1961:150, 1968:349; Grousset, 1970:356.

68 Rashīd al-Dīn, 1954:715.

69 Ibid., 713.

70 Ibid., 714.

71 Amitai-Preiss, 2004:17.
} 
To my knowledge, there was no Great Quriltai's or Court mandate to control Syria and Egypt. It is not obvious who made the decision to conquer Syria. If we believe Het'um Patmich', it is only known, that the Armenian King Het'um twice expressed his interest to the Mongol Khan in freeing the Holy Land from the Muslims, once visiting Mönkge Khan in Qara-Qorum in 1253/1254, and the second time visiting Hülegü in Maragha in 1258. ${ }^{72}$

There is disagreement among the sources about what happened after the conquest of Baghdad and when Upper Mesopotamia was invaded. According to Rashīd al-Din, Hülegü set out from Azerbaijan to Syria on 12 September 1259. While moving towards Aleppo, he sent his son Yoshmūt to Mayyāfāriqīn and al-Ṣālih Ismāềl, the son of Badr al-Dīn Lu'lu', to Āmid (Amida). ${ }^{73}$ According to Kirakos Gandzakets'i and Vardan Arevelts'i, Hülegü despatched his son to besiege Mayyāäriqin and Amida soon after the fall of Baghdad, i.e., in the Spring of $1258 .{ }^{74}$ Jūzjāni is in agreement with them. ${ }^{75}$ Based on the narrations of Ibn-Shaddād (1217-1285), Patton states that Mayyāfāriqīn and Amida fell in November 1258, almost a year before Hülegü's raid on Syria. ${ }^{76}$

The Ayyubid ruler of Mayyāfāriqīn and Amida, al-Kāmil Muhammad, had broken his vow to Hülegü to supply troops for the siege of Baghdad. ${ }^{77}$ Nevertheless, Al-Kāmil tried to end the Mongol offensive through negotiation; however, the resistance of the Muslim army in Syria forced the Mongols to continue the siege. ${ }^{78}$ Both Kirakos Gandzakets' $i$ and Rashìd al-Dīn assert that the Mongol Ilkei Noyan, the ancestor of Jalayirids, initiated negotiations and summoned the

72 According to Het'um Patmich', before Hülegü's march on Syria, the Armenian king waited for Hülegü in Edessa to assert once more his Christian interest in the Mongol conquest of Palestine and the liberation of the Holy Land from the Sultan of Aleppo (Het'um Patmich', 1951:49-50).

${ }_{73}$ Rashìd al-Dīn, 1954:719.

${ }^{74}$ Kirakos Gandzakets'i, 1961:384; Vardan Arevelts'i, 1991:150.

${ }^{75}$ Jūzjānī, 1970:1269-1270.

76 Patton, 1991:63. Mayyāaāriqīn was a small city but a strong fortress (Jūzjānī, 1970:1268).

77 Al-Kāmil visited Mongolia to present his submission and was granted yarligh and paiza by Mönkge Khan in 650 H. (1253) (Rashīd al-Dīn, 1954:727; Humphreys, 1977:335). He came back to Iraq with Hülegü in 1257 (Jūzjānī, 1970:1266; Patton, 1991:62). In fact, al-Kāmil marched with his troops towards Baghdad, but to aid the Caliph. On his way, he received information about the fall of Baghdad and he turned back (Jūzjānī, 1970:1267-1268).

${ }^{78}$ Patton, 1991:63. 
people of the city of Mayyāfāriqin to surrender. ${ }^{79}$ The conditions were to pay taxes and provide troops to the Mongols. However, the Sultan refused and fortified the city. ${ }^{80}$ Yoshmūt and Ilkei Noyan left their troops in the city and went as far as the river Euphrates, taking quantities of booty before returning to the troops that were besieging Mayyāfāriqīn. Upon their request, Hülegü sent support, in the form of Mongol-Christian troops commanded by a certain Chaghatai (whom Rashīd al-Dīn calls ارقتو) and the Armenian Prince Pŕosh Khaghbakian. ${ }^{81}$ The Governor of Mosul, Badr al-Dīn Lu'lu', who was in conflict with al-Kāmil Muhammad, sent a supporting force to the Mongols commanded by his son, along with siege engineers to Mayyāfäriqinn. ${ }^{82}$ In the battle, catapults and arbalests were employed on both sides. ${ }^{83}$ In fact, Armenian sources relate different details of the siege of Mayyāfäriqin. Kirakos records that the city suffered so much from famine that one litr of human flesh was sold for seventy dahekans.$^{84}$ Sebastats $i$ states that one litr of human flesh cost a hundred dahekans. ${ }^{85}$ Grigor Aknerts'i explains that the city was besieged for three years because it was the city of martyrs full of holy relics and built by the holy Marut'a. The siege lasted until the citizens began to eat each other and the head of a donkey cost thirty drams (dirhems) ${ }^{86}$ Step'annos Episkopos states that the city was under siege for one year (1259) and fell due to Hülegü starving the citizens. ${ }^{87}$ Probably the city fell in April $1259^{88}$ but Amida held out until the beginning of $659 \mathrm{H}$. (1261). ${ }^{89}$ Another point stressed by Kirakos is that the sultan of the city was found by the Mongols faint from hunger. When he was brought to Hülegü, the latter gave orders to kill him along with his brother, as they were guilty of bloodshed and human casualties. ${ }^{90}$ Many people died on both sides. Vardan

\footnotetext{
79 Rashīd al-Dīn, 1954:725; Kirakos Gandzakets'i, 1961:384.

${ }^{80}$ Rashīd al-Dīn, 1954:725.

${ }^{81}$ Kirakos Gandzakets'i, 1961:385.

82 Patton, 1991:63.

${ }^{83}$ Jūzjānī, 1970:1272(note 5); Kirakos Gandzakets'i, 1961:385.

${ }^{84}$ Ibid., 385-386.

${ }^{85}$ Sebastats'i in Hakobyan, 1956:142.

${ }^{86}$ Grigor Aknerts'i, 1974:42.

87 Step'annos Episkopos, 1951:43.

${ }_{88}$ Vardan Arevelts‘i, 1991:150. According to Jūzjānī, Mayyāfāriqīn was besieged for more than three months (Jūzjānī, 1970:1270).

89 Patton, 1991:63.

${ }^{90}$ Kirakos Gandzakets'i, 1961:387. The same event is interpreted differently in the Persian source, where all the citizens except 70 people died from famine and
} 
Arevelts'i records that the Armenian Prince Sevada Khachents' $i$, the son of Prince Grigor, was killed in this battle. ${ }^{91}$ Nonetheless, churches and countless relics of the saints were saved in this city. The Armenian soldiers told the Mongols about the venerability of the relics and they even saw many visions of saints and bright lights over the walls of one particular church. ${ }^{92}$ Probably in the same church, the Armenian Prince Taq-i al-Din (Ountumpk ) from the Bagratuni family in Sasun, seized a Syrian priest and made him promise to return the right hand of the holy apostle Bartholomew. The holy relic was brought first to Taqi al-Dīn's monastery and then, on the demand of Lord Sadun, the grandson of Sadun Artsruni, it was deposited in the Monastery of Haghbat (in the district of Lorii)..$^{93}$ The Armenian source records that after the sack of these cities, the Mongols came to Sasun, and since Prince Sadun was a protégé of Hülegü, Sasun was given to him. ${ }^{94}$

\section{The Implementation of a Cilician Armenian Dream}

Hủlegű stayed in Azerbaijan for over a year preparing for his third campaign against the Ayyubid states in Syria. ${ }^{95}$ He remained mostly in Maragha (Marāgheh), where, under his patronage, Nașir al-Dīn Țūsi and other scholars began to erect the famous astronomical observatory. ${ }^{96}$ As has been noted above, Hülegü had already asserted himself as the ruler of the new Mongol state in Rūm, Iraq, Iran, Afghanistan and the Caucasus. During the Summer of 1258, he received his vassals in Maragha: Badr al-Dīn Lu'lu of Mosul, atabeg Abū Bakr of Fārs, the Sultans of Rūm, 'Izz al-Dīn and Rukn al-Dīn, and the Caucasian lords. ${ }^{97}$

al-Kāmil Muhammad was tortured to death by being forced to eat his own flesh (Rashīd al-Dīn, 1954:727).

${ }^{91}$ Vardan Arevelts'i, 1991:152.

${ }^{92}$ Kirakos Gandzakets'i, 1961:387. Jūzjānī records that there was a Christian church in the city of Mayyāfāriqīn called Markūmah which was full of sanctity (Jūzjānī, 1970:1268).

${ }_{93}$ Grigor Aknerts'i, 1974:42-43.

${ }^{94}$ Later, Sasun was sacked by the Mongols who broke their oath (Kirakos Gandzakets'i, 1961:386).

${ }^{95}$ Boyle, 1968:349.

96 Rashīd al-Dīn, 1954:718. Nașīr al-Dīn Ṭūsī produced for Hủlegü and his son Abaqa a treatise on government finance (Minorsky, 1964a:64-85).

97 Boyle, 1968:349. 
The motive for these visits may have been related more to the extension of their agreement with the Mongols rather than to congratulate Hülegü on the occasion of his victory and proclamation as an Il-Khan. ${ }^{98}$ As the Armenian King Het'um wished, the Mongol Khan agreed to free the Holy Land from the Muslims. ${ }^{99}$

On the other hand, as Badr al-Dīn Lu'lu' of Mosul had greatly aided the Mongols in invading Iraq and overthrowing 'Abbasid's rule earlier on, ${ }^{100}$ there was a Muslim appeal against the Ayyubids as well. On the eve of the Mongol invasion, Egypt and Syria experienced a period of internal political conflict, civil disorder and conspiracies. ${ }^{101}$ Three major important Ayyubid figures: al-Nāșir Yūsuf b. al-'Azīz Muhammad, the Sultan of Aleppo and Damascus, al-Manșūr Muhammad b. al-Muzaffar Maḥmud, the ruler of Hamā, and al-Mughìth 'Umar b. al-'Ādil Abu Bakr, the ruler of Karak, had all shown their willingness to cooperate with the Mongols. Another Ayyubid, al-Ashraf Mūsā, the former Prince of Homș, had maintained a correspondence with the Mongols since $651 \mathrm{H}$. (1253-1254). ${ }^{102}$ In fact, al-Ashraf Mūsā encouraged Hülegü to invade Syria in order to be reinstated. ${ }^{103}$ Besides these, the other Ayyubid amirs, merchants and the chief chamberlain, as well as the Kurdish amirs, promoted a submissive policy towards Hülegü. ${ }^{104}$ There was also sectarian conflict between the Sunnis and the Shi' as, which might have encouraged Hülegü's determination to march on Syria. ${ }^{105}$ Therefore, in addition to the Cilician Armenian interest, there was a certain interest on the part of some Ayyubid leaders in bringing the Mongols to Syria.

As has been said above, Hülegü set out from Azerbaijan in September 1259, having sent ahead his general Ket-Buqa with the advance forces. According to Grigor Aknerts'i, Hülegü picked two

${ }^{98}$ It is not clear who bestowed the title Il-Khan on Hülegü. Amitai-Preiss suggests that Hülegü adopted the title of his own volition (Amitai-Preiss, 2004:14).

99 Ibid., 45-46.

100 Patton, 1991:3.

101 Amitai-Preiss, 2004:17.

${ }_{102}$ Humphreys, 1977:341-342; Amitai-Preiss, 2004:19-21.

103 Al-Ashraf Mūsā was received by Hủlegü at Aleppo and retained Homṣ and the title of the ruler over all Syria. Hülegü also granted him an $i q t \bar{a}^{\prime}$, revenues of land assignment (Amitai-Preiss, 2004:20, 31).

104 Ibid., 22.

${ }^{105}$ Besides the conflicts, palace intrigues reached a high level, which contributed to the decision of Hülegü (Rashìd al-Dīn, 1954:698-703). 
out of every ten men of the assembled army for the march on Syria. ${ }^{106}$ Hülegü demanded that the Georgian King David Ulu support his conquest of Syria and Egypt. Surprisingly, David refused. One might have expected that the Georgian king would have been more than interested in liberating the Holy Land. However, David was not only disinterested in this venture, but also bold enough to refuse Hülegü's order. In addition, he sought a revolt, which was suppressed by Arghun Aqa in Southern Georgia in $1260 .{ }^{107}$ David Ulu's refusal to participate in the Mongol campaign in Syria can be explained by his huge loss of men in the battle for Baghdad. In these circumstances, Hủlegü called for the Cilician Armenians and set out for Syria. He personally commanded the centre, placing commanders Baiju and Shiktür on the right flank and other amirs on the left. ${ }^{108}$ The army passed through Ala-Tagh, Akhlāt and the Hakkārī mountains into Diyārbakr or Amida, which was captured by the son of Badr al-Dīn Lu'lu'. ${ }^{109}$ Hülegü himself captured Edessa, Dunaysir, Nisībin/Nisibin and Harrān ${ }^{110}$ (see Map 5). After crossing the Euphrates, the Mongols surrounded Aleppo, where they were joined by the troops of the Cilician Armenian King Het'um and his son in-law, Bohemond VI, the Prince of Antioch (1252-1268) and the Count of Tripoli (12521275). ${ }^{111}$ Among those who arrived was the Armenian Catholicos Kostandin (Constantine) I (1221-1267) who came to bless Hülegü's march, as the Armenian chronicler attests, in order to 'free all the Christians, clerics and people from death. ${ }^{112}$ This account indicates the importance of this conquest for the Armenians.

The siege of Aleppo started. The inhabitants of Aleppo, trusting in the impregnability of their citadel and of the five secure gates (Jews' Gate, Anatolia Gate, Damascus Gate, Antioch Gate and Iraq Gate) refused to surrender and preferred to fight the Mongols. The

${ }^{106}$ Grigor Aknerts 'i, 1974:49. Estimates of the size of Hülegü’s army range from 15,000 to 120,000 (Smith, 1975:274-278; Allsen, 1987:203-207).

107 Kirakos Gandzakets'i, 1961:390.

108 Rashīd al-Dīn, 1954:719.

109 According to a Persian source, the army killed many Kurds in Akhlāt and in the mountains of Hakkārī (Rashīd al-Dīn, 1954:719).

110 Ibid., 719.

111 Boyle, 1968:350. The conquest of Aleppo signified the entrance of the Mongols into the principality of Antioch and the county of Tripoli. In return for his military support, Bohemond retained the districts in the Orontes valley which he restored to the principality of Antioch (Jackson, 2005a:117).

112 Vardan Arevelts'i, 1991:151. 
city was finally taken through the Iraq Gate and the siege of the town lasted less than a week. ${ }^{113}$ The following episode in the siege of Aleppo is documented by Smbat Sparapet:

In the year 1260, Khan Hulagu and his mighty host advanced like a Spring torrent, seizing the forts of the infidels wherever they passed, some peacefully, some by fighting. Thus he advanced as far as Aleppo, surrounded the city, and sent word to King Het'um to join him; and the latter immediately came to the Khan with his army, and the Khan received him joyfully. And the victorious Khan harassed Aleppo with numerous engines, and in seven days he opened a way for the invaders in spite of the great width of the ramparts and the depth of the ditch. Then they all raised such a loud cry that the earth shook and trembled at the sound; entering, they marched on the citadel. ${ }^{114}$

For many days and nights, they battled against the defenders in the citadel of Aleppo where catapults and arrows were used by both sides. ${ }^{115}$ As Bar Hebraeus relates, the greater number of the Christians were gathered in the church of the Greeks. The Armenian noble T'oros and the monk Kürāk liberated them and brought them to the Syriac church in Maragha. ${ }^{116}$ Ibn Shaddād and other Arab historians stress the reprehensible role of Het'um in the siege, who set fire to the Great Mosque of Aleppo. ${ }^{117}$ In Muslim historiography, this theme of the plunder of mosques by the Armenians continued until Il-Khan Ghazan's reign. ${ }^{118}$ Ibn Shaddād states that Hülegü, having learned what Het'um had done to the mosque, became angry and had a large number of Armenian troops massacred. ${ }^{119}$ To my knowledge, the contemporary Armenian sources say nothing about setting fire to the mosque, the massacre, the conversion of the mosque into a church, nor the execution of the Armenians by Hülegü. The reference to similar actions in Damascus, but this time attributed to Bohemond VI, is found in the Deeds of the Cypriots, saying:

The King of Armenia and the Prince of Antioch [Bohemond VI] joined the Tartar host and were at the taking of Damascus. When Damascus fell, the prince had a most lovely Church purified and censed ... This

${ }^{113}$ Rashīd al-Dīn, 1954:719. Aleppo was taken from 18 to 24 January and the citadel on 25 February 1260 (Boyle, 1968:350; Amitai-Preiss, 2004:26).

114 Smbat Sparapet Chronicle cited in Der Nersessian, 1973:370.

115 Rashīd al-Dīn, 1954:719.

116 Bar Hebraeus, 2003:436.

117 Boyle, 1968:350; Ibn Shaddād in Stewart, 2001:41.

118 See Chapter 7.

119 Jackson, 1980:495. 
was originally the church of the Greeks (that had been turned into a mosque) ... And in other Mohammedan mosques, where the Saracens worshipped, he had roncins and donkeys stabled, and he splashed wine on the walls and smeared them with pork, both salt and fresh. And where he commanded his men to commit one act of defilement, they did ten. ${ }^{120}$

When the city was conquered, many artisans were made prisoner. After the long siege of Hārim fortress near Aleppo, the defenders asked for mercy. ${ }^{121}$ But Hülegü was extremely angry with them and ordered them to be killed. Interestingly enough, only an Armenian goldsmith was spared. ${ }^{122}$ By this time, the notables of Hamā and Homṣ had come to Hülegü and submitted their cities to him. ${ }^{123}$ After Hārim fortress, the citadel of Aleppo was taken, and Hülegü installed a Mongol shahna in Aleppo. ${ }^{124}$

The people of Damascus were frightened by the attacks of the Mongol army. Hülegü ordered Ket-Buqa to go to Damascus and test them and Ket-Buqa arrived there on 14 February $1260 .{ }^{125}$ Since Aleppo was entirely under Hülegü's control, the dignitaries and grandees of Damascus came to the camp of Hülegü bearing all sorts of gifts and the keys to the city gates. ${ }^{126}$ Therefore, without having to lay siege, Ket-Buqa made a triumphal entry into Damascus on March 1, accompanied by the Armenian King Het'um and Bohemond VI. ${ }^{127}$ The inhabitants turned out to greet them and asked for amnesty. Ket-Buqa sent the nobles and dignitaries to Hülegü who showed mercy to them and granted their requests. ${ }^{128} \mathrm{~A}$ Mongol

${ }^{120}$ According to the Gestes des Chiprois, Bohemond converted one mosque into a Latin church and plundered many others (RHC/DA, 2, 171, 751; Crawford, 2003:34-35). Modern scholarship doubts this or any similar behaviour; see Jackson, 1980:486-487.

${ }^{121}$ On the siege of Hārim fortress, see Ibn Shaddād, 1984:42-43.

${ }_{122}$ Rashīd al-Dīn, 1954:720. It is a blacksmith in Bar Hebraeus, 2003:436.

${ }^{123}$ Kirakos Gandzakets‘i, 1961:388.

124 Rashīd al-Dīn, 1954:720.

125 Amitai-Preiss, 2004:30.

126 Grigor Aknerts'i, 1974:49-50; Kirakos Gandzakets'i, 1961:388. The local notables decided to submit with the help of Zayn al-Ḥāfizị who had fostered a pro-Mongol policy for a long time (Amitai-Preiss, 2004:30).

127 Boase, 1978:26

${ }_{128}$ Among the nobles were al-Ashraf Mūsā whom Hülegü allowed to retain his old principality of Homș. Al-Sa id Hasan b. al-'Azīz 'Uthmān who had been released by Hủlegü from al-Nāṣir Yūsuf s jail in al-Bīra on the Euphrates was reinstated as the ruler of al-Șubayba and Banias (Amitai-Preiss, 2004:31-32). 
shahna and three Persians were entrusted to govern Damascus. ${ }^{129}$ According to Kirakos Gandzakets 'i, after Damascus, Hülegü sent troops to the city of Mardin (Utpunhinuj). ${ }^{130}$ From Damascus, Ket-Buqa raided Hebron, Ascalon, Jerusalem and Nablus. ${ }^{131}$ Although scholars dispute the siege of Jerusalem by Hülegü, they agree that Hülegü was bound for the Holy Land. ${ }^{132}$ The reason why Hülegü was interested in the controlling of the Holy Land, which is stressed by Armenian historians, could be explained by the fact that the place was contested by the Christian and Muslim powers. By controlling the Holy Land, the Mongols could manipulate the sensitivities of both parties. However, Hülegü did not actually make any special arrangements for Jerusalem. By the time he had conquered Aleppo, al-Nāșir Yūsuf, the Sultan of Aleppo and Syria had fled to the fortress at Karak. ${ }^{133}$ Ket-Buqa wanted to lay siege to Karak but the Sultan of Aleppo asked for mercy and capitulated. Ket-Buqa sent al-Nāṣir Yūsuf to Hülegü in Tabriz who promised to give him the governorship of Syria after his defeat of Egypt. ${ }^{134}$

The main achievement of the Mongol-Cilician Armenian military alliance was the fall of Aleppo and Damascus. The alliance brought a certain immediate benefit to the Armenians. According to Het'um Patmich', after the capture of Syria and Palestine, King Het'um received territory in western Cilicia along with several fortresses taken from the Armenians by the Muslims. ${ }^{135}$ In fact, Het'um expanded his territories on the Cappadocian, Mesopotamian and Syrian borders where the trade routes passed. ${ }^{136}$ Hülegü gave Bohemond the port of Latakia in return for his reinstatement of the Greek patriarch of Antioch. ${ }^{137}$

\footnotetext{
129 Rashīd al-Dīn, 1954:720. For shahna, see Chapter 4.

130 Kirakos Gandzakets'i, 1961:388; Sebastats'i in Hakobyan, 1956:143.

131 Jackson, 2005a:116.

132 Spuler, 1943:254. On the Mongol raid into Palestine, see Amitai, 1987(2):236255.

133 Al-Nāșir Yūsuf s ambivalent policy was due to his indecisive nature and opposite opinions of those around him (Amitai-Preiss, 2004:22).

${ }_{134}$ Rashīd al-Dīn, 1954:720.

${ }^{135}$ Het'um Patmich, 1951:50-51; Burger, 1988:xviii.

136 Stewart, 2001:46.

${ }^{137}$ Bohemond restored the districts in the Orontes valley (Kafr Bilmīs, Dayrkūsh and Kafr Dubbin) to the principality of Antioch which remained in his hands until it fell to Baybars in 1268 (Jackson, 2005a:117).
} 
In a short time in early 1260 , Syria and Palestine were conquered and brought under Hülegü's control. Now Hülegü confronted the last power of the Islamic states: Egypt, the dream of the Crusaders.

The achievement of Hülegü as a conqueror and an empire-builder is enormous. He was the carrier of the 'imperial ideology,' as AmitaiPreiss identifies this phenomenon. ${ }^{138} \mathrm{He}$ actively supervised battles on four different fronts: against the Ismāîlīs; the 'Abbasid Caliphate; the Mamluks of Egypt and the Golden Horde (initially Ulus of Jochi). As has been said above, having destroyed both the 'Abbāsid Caliphate and its Ismāîlī opponents, Hülegü extended the Mongol conquest to the shores of the Mediterranean and left his successors in control of a territory corresponding to the greater part of what we now call the Middle East. As Boyle indicates, it is due to him and his successors that Iran came into direct contact with the West for the first time since antiquity. ${ }^{139}$

The involvement of Greater Armenia was mostly based on the obligations of their vassal status to serve in military actions. Among the Greater Armenian dynasties, Prosh Khaghbakian through his loyal service strengthened his position and his House, which later would be known as the Proshians. ${ }^{140}$

The involvement of the Cilician Armenians, by contrast, was voluntary in the sense that it was consistent with their own interests and objectives and it had far-reaching political consequences. The Mongol victory in Mesopotamia allowed King Het'um I to expand his realm not only geographically to the Cappadocian, Mesopotamian and Syrian frontiers, but also economically, giving him the chance to control trade routes. ${ }^{141}$

Following his ancestral tradition of religious tolerance, Hülegü had no desire for a religious war. However, being reminded several times by the Armenian King Het'um, Hülegü saw clearly that there was a power-vacuum in this region that was disputed between the Christian and Muslim worlds. Moreover, he understood that, even within the Muslim world, control of Syria was contested between the

${ }_{138}$ Amitai-Preiss, 2004:9.

139 Moreover, the dynasty founded by Hülegü may be said to have paved the way, however unwittingly, for the centralising nationalistic policies of the Șafavids (Boyle, 1968:355).

${ }^{140}$ Hovsep'ean, 1928:16-17, 36-45; Babayan, 1976:546-550.

141 Stewart, 2001:46. 
Ayyubid princes and the new Mamluk state in Egypt. In order to reach his imperial goals, Hülegü drew on the resources and supports of his allies and subjects in the region. As has been said, among the first Mongols in Iran, the Christian interest was more influential; this is especially the case with the Il-Khanid hierarchy, in which the wife of Hülegü, Doquz Khatun, promoted the Christians. If the destruction of the Assassins brought much rejoicing to the orthodox Muslim world, the actual fall of Baghdad and the end of the 'Abbasid Caliph's line met with the opposite reaction. Lamentation over the fall of the glorious city of Baghdad is found in Muslim literature. The Arab writer adh-Dhahabi wrote a qașida, or ode, which belongs to the class of the marthiyya-qasidas, in which the final accord says that no-one hoped to remain alive after that veritable Day of Judgement; another was written by the famous Persian poet, Sa'di of Shiraz. ${ }^{142}$ Mongol incursions into Aleppo and the Ayyubid principalities of Syria and Palestine made the Mongols the most hated enemy of the Muslims. However, for the Christians, these raids represented some sort of divine judgement of the infidels. ${ }^{143}$

It is worth emphasising that a Muslim-Mongol alliance contributed to the success of Hülegü as much as a Christian one. The submissions and military services given by the Muslim rulers, namely Badr al-Lu'lu' of Mosul, Prince al-Ashraf Mūsā of Homṣ (at the beginning of his submission), al-Mughith 'Umar, the ruler of Karak, al-Sa id Hasan of Banias, and many others, had their own impact on the implementation of Mongol ambitions. ${ }^{144}$ On the other hand, despite the fractured political situation in Syria, Hülegü's conquest of Northern Syria made opposing Muslim leaders forget their past conflicts and unite against the Mongol threat. ${ }^{145}$

${ }^{142}$ Somogyi, 1933-1935:46-47; Browne, 1906:29-30.

143 Kirakos Gandzakets'i, 1961:383-384; Bar Hebraeus, 2003:423.

${ }_{144}$ Amitai-Preiss, 2004:32, 40.

${ }^{145}$ Ibid., 2004:35. 


\section{THE IL-KHANS' WARS AND MONGOL-CILICIAN ARMENIAN COLLABORATION: STAGE II (1260-1265)}

Mongol-Armenian cooperation proved itself in practice to be a successful venture that overthrew the Muslim supremacies. The elimination of the Ismā'ili and 'Abbasid powers, the invasion of Aleppo and Damascus by the forces commanded by Hülegü and Het'um I did not stop the latter's ambitions. Their advance further into Syria signified a new development in the history of the Near East, establishing an exclusive triangle of relationships between the Mongols, Mamluks and the Cilician Armenians that carried on for more than 60 years. This section of book examines the wars of the Il-Khans against the Mamluk sultans and against the Golden Horde in 1260-1265. Both wars involved the Armenians. The Il-Khans' confrontation with the Mamluks was implemented with the help of the Cilician Armenians and the efforts to resist the Golden Horde took place in the territories of Greater Armenia. If participation of the Cilician Armenians in the Il-Khanid war resulted in a gain, the Greater Armenian lords' activity was limited to observing their land being devastated by the Chinggisids' wars.

\section{Joint Ventures of Hülegü and Het'um I in Syria}

As one can see from the previous chapter, the pairing of Hülegü and Het'um I had a glorious start. However, after 1260, Hülegü was mostly busy with affairs within the Mongol Empire, so Het'um dealt mainly with Hülegü's representatives.

When messengers brought news to Hülegü of Great Khan Möngke's death (11 August 1259), it was already the early Summer of 1260. Hülegü left Syria and arrived in Akhlāt on 6 June 1260 and then he withdrew to Tabriz. ${ }^{1}$ As Jackson notes, there is a striking

Rashīd al-Dīn, 1954:720. The apparent delay in news arriving undeniably reflected in the rivalry between members of the Chinggisid clan to succeed to the Mongol throne. 
parallel between Hülegü's retreat from his advance into Egypt and Batu Khan's withdrawal from Eastern Europe following Ögodei Khan's death (1241), which saved Europe from Mongol conquest. ${ }^{2}$

According to Armenian sources, Hülegü's withdrawal from Syria was possibly connected with his intention of wintering in the Hamadān plain, which seems to be a plausible suggestion. ${ }^{3} \mathrm{He}$ left his victorious general Ket-Buqa in command of a small army, less than two tumans (20,000 men), in Syria. As a potential Great Khan, Hülegü took the vast majority of his army with him. ${ }^{4}$ Amitai-Preiss attributes the act of leaving Ket-Buqa with such a small army to faulty intelligence and underestimation of the size of the Egyptian forces. ${ }^{5}$

The Egyptian army was under the command of al-Muzaffar Sayf al-Dīn Quțuz (1259-1260), the atabeg and ruler of Egypt. In the same year 1260, before his withdrawal, Hülegü had sent envoys to Cairo demanding Quțuz's surrender making conflict more or less inevitable. Having called his commanders to a council, Qutuz decided to respond to Hülegü by killing the envoys. ${ }^{6}$ He resisted the Mongols as justification for his own accession to the throne (16 November 1259) for he claimed to be a descendant of Khwārazm-Shāh 'Alā' al-Dīn Muhammad. He pursued an anti-Mongol policy as his personal revenge. ${ }^{7}$ The Persian source recounts that many of the fugitives and stragglers of Khwārazm-Shāh Sultan Jalāl al-Dīn had fled to Egypt after hearing about the advance of Hülegü on Upper Mesopotamia. ${ }^{8}$ However, having found refuge with Quțuz, they formed the substantial part of his army. ${ }^{9}$ When Hülegü retreated home, Qutuz prepared for war with the Mongols.

Qutuz allied with his former opponent, a fellow Mamluk, Baybars al-Bunduqdārī, who had fled Syria after the Mongols captured Damascus. ${ }^{10}$ The Mongols attempted to ally with the remnants of the

${ }^{2}$ Jackson, 2005a:116.

3 Ibid., 230. It is the plain of Hemian (Ltuhhuinuj) in Kirakos Gandzakets'i, 1961:388; Grigor Aknerts'i, 1974:50; Smbat Sparapet in Galstyan, 1962:53.

${ }^{4}$ Vardan Arevelts'i, 1991:152; Kirakos Gandzakets'i, 1961:388.

5 Amitai-Preiss, 2004:29.

${ }^{6}$ Rashīd al-Dīn, 1954:721-722.

7 Amitai-Preiss, 2004:35.

8 Rashīd al-Dīn, 1954:721.

${ }^{9}$ Ibid., 721.

${ }^{10}$ Enmity existed between Quțu and Baybars because of the murder of the Bahriyya regiment's former leader, sanctioned by Quțuz, followed by numerous 
Crusader Kingdom of Jerusalem, now centred in Acre, but Pope Alexander IV (1254-1261) forbade this. ${ }^{11}$ This action was reasonable, since a ten-year peace had been concluded between the Franks of Palestine and Damascus in 1254, and Egypt in $1255,{ }^{12}$ and the neutral position of the Franks towards the Mamluks was renewed at Acre in $1260 .{ }^{13}$ In September 1260, the Mediterranean Latin states allowed Mamluk troops to march through Latin Palestine against a joint force of Armenians and Mongols. ${ }^{14}$ The reason why the Franks remained resistant towards Mongol assistance was very simple, for as Jackson states, this was the only rational assessment in those circumstances. ${ }^{15}$ As the Franks believed that one day the Mongols would wipe them out as well, they were not in favour of helping them. ${ }^{16}$ Secondly, they did not want Quțuz to turn against them, so they agreed that the Egyptian army could cross their territories although they ended up delivering supplies for the Sultan's troops. ${ }^{17}$ It was a perfect moment for Qutuz, who decided to march north on Syria and confront the occupying army left under the command of Ket-Buqa Noyan, confident that even in defeat he could still withdraw to Egypt for reinforcements. In addition, he was sure that, as the Mongol troops had just finished their exhausting ride through the desert, there was no hope that Hülegü would return with his full army. ${ }^{18} \mathrm{He}$ believed that defeating this force would not only protect the holy places, such as Jerusalem, Mecca and Medina, but also would drive the Muslims into

raids and attempts to invade Egypt from Ayyubid Syria under Baybars' leadership. However, the threat caused by the Mongols brought these two into temporary alliance (Amitai-Preiss, 2004:35).

11 Jackson, 2005a:119.

${ }^{12}$ Thorau, 1987:142.

${ }_{13}$ Jackson, 2005a:121.

14 The notion that Ket-Buqa, disobeying the instructions of Hülegü to remain in the newly-conquered region, waged war with Egypt having a reinforcement of 500 soldiers from Cilicia, is found only in Smbat Sparapet's Chronicle in Der Nersessian, 1973:370. By such a statement, Smbat possibly tried to justify the defeat.

${ }^{15}$ Jackson, 2005a:121.

16 Rashīd al-Dīn mentions a certain Amir Baydar, a subordinate of Ket-Buqa, who was informed about the advance of Egyptian troops via the Latin coast (Rashīd al-Din, 1954:722). According to the scholars quoting the Mamluk sources, Baydar was a commander of the Mongol force dispatched to Gaza in order to prevent the Egyptians from sending assistance to the Franks on the coast (Amitai-Preiss, 2004:33; Jackson, 1980:496).

17 Under the Mamluks, the principality of Antioch fell in 1268, the county of Tripoli in 1289, and the Kingdom of Jerusalem in 1291 (Jackson, 2005a:118-119).

${ }_{18}$ Amitai-Preiss, 2004:38. 
a rage against the resolute Mongols. Essentially, he accomplished all these goals.

As Amitai-Preiss noted, the war between the Mongol Il-Khans and the Mamluk Sultans of Egypt and Syria lasted until 1320 in various forms of confrontation, commencing with the battle of 'Ayn Jālūt in 1260. ${ }^{19}$ This battle had very important consequences for all its participants, Mongols, Mamluks and Armenians. The Mamluk and Mongol armies encamped in Palestine in July 1260, ${ }^{20}$ finally met at 'Ayn Jālūt near Zar'īn on 3 September of the same year, with both sides numbering about 20,000 men. ${ }^{21}$ Armenian sources name the place of the battle as the plain of Mount T'abor (Aupnpulquil) ${ }^{22}$ or the locality called Prr $\left(\pi_{p}\right)$ ). ${ }^{23}$ According to Rashīd al-Dīn, the Mamluks drew out the Mongol mounted archers with a feigned retreat. The Mongols were almost unable to withstand the assault from the Egyptian ambush, and Quțuz rallied his troops for a successful counter-attack, using cavalry reserves hidden in the nearby valleys. The Mongols were forced to retreat and Ket-Buqa was left alone. His horse fell and he found refuge in a thicket of rushes where a small number of Mongols were hidden. When Qutuz set the rushes on fire, Ket-Buqa was captured and executed. ${ }^{24}$ Many Armenians and Georgians were killed with Ket-Buqa. ${ }^{25}$ The Armenian source attributes the failure of the Mongols to the excessive heat and the sickness among their horses. ${ }^{26}$ In a letter to the French King Louis IX dated 1262, Hülegü himself explained his withdrawal from Syria as being due to the exhaustion of grazing land and provisions, and the discomfort of heat in Summer. ${ }^{27}$ Also, the timely desertion of al-Ashraf Mūsā, the governor of Homș who previously had been

19 Ibid., 1999:57.

${ }^{20}$ Quțuz had at first agreed to wait for Ket-Buqa at Șālihiyya to get the amirs to mobilise; however, knowing that a prolonged wait would not be in his favour, he convinced the amirs to follow him speedily (Amitai-Preiss, 2004:37).

${ }^{21}$ Het'um Patmich gives the number of Ket-Buqa's army as 10,000 men (Het'um Patmich, 1956:70). For different figures on both sides, see Amitai-Preiss, 1992:119150, 2004:36-37; Smith, 1984a:308-344.

${ }^{22}$ Kirakos Gandzakets'i, 1961:389.

${ }^{23}$ Der Nersessian, 1973:370.

${ }^{24}$ Rashīd al-Dīn, 1954:723.

${ }^{25}$ Kirakos Gandzakets'i, 1961:389.

${ }^{26}$ Der Nersessian, 1973:370. Although the hot climate of Palestine and Egypt did not suit the Mongols, they left these lands only after their defeat by the Mamluks (Halperin, 1985:48).

${ }^{27}$ Meyvaert, 1980:258; Jackson, 2005a:120. 
allied with the Mongols, and who was on the Mongol left flank in this battle, contributed to the Mamluk victory. ${ }^{28}$ Furthermore, the Mamluk heavy cavalrymen were masters of close combat, a form of warfare never previously experienced by the Mongols. Besides, the bulk of the Mamluks were Inner Asian nomads of Turkic (or Circassian/Qipchak) origin sold via Constantinople in Cairo to the Sultan of Egypt. ${ }^{29}$ It is important to note that both the Mamluks and Mongols were the military elites of the Eurasian Steppe. ${ }^{30}$ The Mamluks were not only great equestrians themselves, familiar with steppe warfare, but very well aware of Mongol tactics and weapons. ${ }^{31}$ Until 1517, the Mamluks were the unchallenged masters of military force in Egypt. ${ }^{32}$

When the news of the death of Ket-Buqa, the defeat of the Mongol army and its withdrawal across the Euphrates reached Hülegü, he decided to dispatch a second conquest of Syria with a large force of Mongol cavalry under one of his commander. ${ }^{33}$ Recent scholarship suggests that the Mongols advanced as far as Homș but were defeated in battle in December 1260, and for the second time were driven back across the Euphrates and were completely expelled from Syria. ${ }^{34}$ For the Mongols, this failure marked the end of the unity of the Mongol Empire, though some parts of it would last another 250 years. 'Ayn Jālūt represented a similar situation to that of Hakata Bay (Iki Island), where the fleet of Qubilai Khan was defeated by the Japanese Shogunate in 1274 and 1281, ending Mongol expansion in Japan.

28 Amitai-Preiss, 2004:43.

${ }^{29}$ Smith, 1984a:314.

${ }^{30}$ Amitai-Preiss, 2004:2.

31 Ayalon, 1963:49.

${ }^{32}$ Chahin, 1987:286. On the way back to Cairo after the victory at 'Ayn Jālūt, Baybars killed Quțuz and became Sultan himself. His successors would go on to capture the last of the Crusader states in Palestine by 1291.

${ }_{33}$ Rashīd al-Dīn, 1954:723.

${ }^{34}$ According to Mamluk sources of the later period, on Friday 11 December 1260 , there was a great battle near the northern citadel of Homs between the Mongols and forces of Aleppo, Hamā and Homș, where the outnumbered Muslims were victorious over the Mongols who were discomforted by the sun and fog. Although the victory near Homs was achieved by the Ayyubids of northern Syria, this battle would be considered by the Mamluk sources as greater than the one at 'Ayn Jālūt, due to the Muslims having no numerical advantage, about 1,400 men under the command of al-Ashraf Mūsā against 6,000 Mongol horsemen commanded by Baydar (Amitai-Preiss, 2004:51-52). 
The defeat of Ket-Buqa had a serious effect for the Armenians: Their desire to free the Holy Land was quashed. The Mamluks ravaged much of Antioch and Cilician Armenia in the following year. ${ }^{35}$ Nevertheless, even after the Mongol failure in battle against the Mamluk army, the Armenian Kingdom of Cilicia maintained its territorial integrity and Het'um was able not only to hold his own, but also to expand his territories during the first half of the Il-Khanid period.

In 1262, a joint force of Mongol-Armenian troops allowed Het'um to occupy Behesni and Marash. However, the victory of the Mamluks at 'Ayn Jālūt not only saved Egypt from the Mongol advance but also encouraged the Muslims in Damascus and Aleppo to revolt against the Cilician Armenians. The Mongols, pushed back and contained in Iran, were too distant to help Cilicia against the newly-powerful Mamluks. Regardless of this, the Mongols were the only protectors of the Armenians. According to Smbat's Chronicle, in 1263 King Het'um went to Hülegü Khan to complain about 'the people of Cappadocia who molested the Cilicians' and Hülegü sent Mongol judges (yarghuchis) after him to solve the problem with the Sultan of Rùm, Rukn al-Dīn. Under the supervision of the Mongol judge, Het'um met Rukn al-Dīn in Heraclea to discuss the division of the port. $^{36}$

Considering himself to be supported by the Mongols, in 1264 King Het'um gathered his army of infantry and invaded the province of Aleppo and a few small towns nearby. According to Smbat Sparapet, they won rich booty, but confronted a small Muslim force in one of these towns. Het'um escaped and returned home alive with the booty. The same year Het'um again assembled his army and marched on the fort of Aintab, but returned to his land without having been able to reach the fort. After a short time, during the Winter, he made an unsuccessful attempt to take this fort again. ${ }^{37}$

One more attempt by a joint Mongol-Armenian advance on Syria was made in 1264-1265. Hülegü Khan sent Turba, one of his commanders, together with a large army to the impregnable fort of al-Bìra, which was in the hands of the Muslims. Turba managed to demolish the walls of the tower. Turba sent to ask King Het'um to

${ }^{35}$ Burger, 1988:xviii.

${ }^{36}$ Het'um Patmich', 1956:72; Der Nersessian, 1973:372.

${ }^{37}$ Smbat Sparapet in Galstyan, 1962:57. 
join him. Het'um sent 200 cavalrymen ahead to Turba and then followed himself. When Turba received news that Baybars, the Sultan of Egypt was coming against him, he left al-Bīra, leaving Het'um no choice except to return home. ${ }^{38}$ The series of expeditions by Het'um into northern Syria during 1262-1264 provoked the Mamluks to undertake further incursions into Cilician Armenia.

Despite the fact that Het'um gained much as Hülegü's ally in terms of his confidence and territories, his solo expeditions were not profitable for him. He needed the Mongols' support and this ensured that he would stay true as a Mongol ally in spite of the failure of the Frankish States to collaborate with the Mongols.

\section{The Participation of the Armenians in the Il-Khanid War against the Golden Horde}

Although the issues related to the wars among the Chinggisids are well documented in primary and secondary literature, it is less well known that these wars had a direct influence on the Armenians. For the Cilician Armenians, these wars played a crucial role in distracting the Mongols' attention from their mutual aim to control the Syrian coast, and for the Armenians in Greater Armenia it was another occasion in which they experienced the devastation of their lands. Control of the Caucasus was always contested between the Jochids and Toluids. Thus, clashes between the Mongol troops, which usually took place on Georgian and Armenian territories almost every year until the collapse of the Il-Khanate in the second half of the fourteenth century, turned into a difficult challenge for the Greater Armenians, who according to their subject status had to take the side of the Il-Khans.

Conflicts within the Mongol Uluses over leadership, the best pastures in Azerbaijan and access through the Derbent Gate, where the trade route from the Golden Horde passed through the Near and Middle East, turned into warfare from 1260. Azerbaijan with its sophisticated manufacturing and textile trade remained a point of discord between the Jochids and Toluids. ${ }^{39}$ Therefore, the Mongol Il-Khans were constantly involved in hostilities on different parts of their borders. These hostilities started with the death of Great Khan

${ }^{38}$ Ibid., 58.

39 Grekov and Jakubovsky, 1950:76. 
Möngke in 1259. By 1262, Hülegü had returned from Syria to his domain in Iran. Instead of retaliating against the Mamluks, he had to shift his attention to the north to face the Golden Horde ruled by Berke (1257/1258-1267)..$^{40}$ When Chinggis Khan divided his vast empire into Uluses between his sons and other family members ${ }^{41}$ according to their seniority, the eldest son Jochi received control of the territories and people between the Altai Mountains and the river Irtysh. Although the boundaries of his realm, which was known later as the Golden Horde with its centre in Sarai, fluctuated, they included the upper Volga, Siberia to the Urals, the northern Caucasus, Bulgaria (for a time), the Crimea and Khwārazm in Central Asia. ${ }^{42}$ Based on information left by Ibn Faḍl-Allāh al-'Umarī, Jackson attests that Chinggis Khan gave his eldest son Jochi not only the Pontic steppe, but also Arrān, Tabrīz, Hamadān and Marāgha. ${ }^{43}$ According to Vașạaf also, Arran and Azerbaijan belonged to Batu's line. ${ }^{44}$ Although Batu Khan, exercising his seniority within the direct line of the Chinggisids, played the role of overseer of the Caucasus until his death, the real masters of Georgia and Armenia were the Mongol noyans until Hülegü arrived in Iran. With Hülegü's arrival, the Armenian lords, who had established direct contact with the Mongol noyans and who experienced relative freedom in dealing with them, had to revise their status, which was limited to being engaged mostly with the provision and military reinforcement of the Il-Khan's army.

Chaghatai (r. 1227-1242), the second son of Chinggis Khan, ruled the territory of Central Asia or the former lands of the Qara-Khitai and Transoxiana as far as Samarqand and Bukhārā with a residence on the Ili River. ${ }^{45}$ Tolui, Hülegü's father, as the youngest son of Chinggis, inherited the Mongol homelands according to Mongol custom.

It is problematic and beyond my immediate purpose to identify what exactly Tolui inherited; however, as I see it, his territories over-

\footnotetext{
${ }^{40}$ Berke was the son of Jochi (d. 1227) and the grandson of Chinggis Khan, as well as the fourth ruler of the Golden Horde, established by his brother Batu Khan (d. 1255). For Berke, see Vásáry, 1990:230-252.

${ }^{41}$ Uluses or Mongol appanages were not limited only to Chinggis Khan's four sons. It is suggested that the territories given to Chinggis Khan's brothers and the rest of the family members were Uluses as well (Jackson, 1999b:36; see Introduction).

${ }^{42}$ Halperin, 1985:25.

43 Jackson, 2005a:125.

${ }^{44}$ Vașșāf, 1856:93.

${ }^{45}$ Halperin, 1985:25; Spuler, 1965:274-280.
} 
lapped with Ögödei's. According to the Secret History, Ögödei was the ruler of Golyn Ulus, or the central Ulus, ${ }^{46}$ which included not only the territories around Qara-Qorum, but also the entire Mongol homeland. It seems that Tolui was left without any actual lands to rule and I would suggest that this might explain why his descendants were sent to Iran to settle there. After the death of Chinggis Khan, these divisions of land stirred up conflicts among the Mongol princes, shifting the boundaries and the sphere of power. When Hülegü, the son of Tolui, arrived in Iran and established himself as a Khan of Rūm, Iran, Iraq, Afghanistan and the Caucasus, this triggered the claims of the Jochids and Toluids to each other's territory. The main cause of their direct clash was to gain control of the pasturelands or resources for nomads in Azerbaijan and in Arran. The route from Russia to these lands would certainly cross the Caucasus, involving Armenia and Georgia in their conflicts.

As has been mentioned earlier, the relationship between the Jochids or the Golden Horde and Armenia was developed in the time of Batu Khan, the grandson of Chinggis Khan, through the Mongol noyans. When Batu Khan died, his son Sartakh (r. 1255-1256) succeeded him. Since Sartakh was brought up by a Christian tutor and was baptised and nurtured by him, in his turn he granted many concessions to the Church and the Christians in his realm. ${ }^{47}$ The partnership of Sartakh and Hasan Jalal, the Armenian lord of Khachen from 1251-1256 may serve as a good illustration of this. ${ }^{48}$ According to the Armenian sources, Sartakh was poisoned by his uncle Berke and someone named Barkach'a (Fuppuzulj). ${ }^{49}$ The death of the pro-Christian Sartakh and the rise of the pro-Muslim Berke would certainly alter the Mongol attitude towards the Christians of the region, including the Armenian lords.

Ulagchi, the son of Sartakh died in 1257, leaving the throne to Berke, a brother of Batu Khan. ${ }^{50}$ Since the core of the Golden Horde's territories was Dasht-i Qipchak, in Berke's time his realm was called

${ }^{46}$ MNT, 2004:94(\$269).

${ }^{47}$ Kirakos Gandzakets'i, 1961:358.

${ }^{48}$ For this partnership, see Chapters 2 and 3.

49 Sebastats'i in Hakobyan, 1956:142; Davit' Baghishets'i, 1956:347. Berke is suspected of having poisoned not only Sartakh, but also Ulagchi and Batu's widow (de Hartog, 1996:53). Barkach'a is Berkecher, the fourth son of Jochi and the uncle of Sartakh (Rashīd al-Dīn/ Boyle, 1971:110).

${ }^{50}$ Vernadsky, 2001:158. Berke launched savage attacks on Poland, Lithuania and Prussia in 1259/1260 (Jackson, 2005a:123). 
Qipchak Khanate. The number of the Mongols was comparatively small among those of the Qipchaks and the Turks who inhabited the area of the Jochids' control and so the Golden Horde's ethnicity was predominantly Turkic. ${ }^{51}$ Consequently, as ruler of a domain based on Turkic culture, the conversion of Berke to Islam was not a complete surprise, although he was the first Chinggisid to adopt Islam. ${ }^{52}$ When the Golden Horde became Islamic, a new element was brought into the ruling system of the Mongols; the profession of the Muslim faith meant that the religious issues of the Mongols became more than a private matter. Berke, who had been converted to Islam in his adolescence but who had pledged to serve the Great Khan Möngke loyally, watched with displeasure as his cousin, Hülegü, destroyed the 'Abbāsid Caliphate, the spiritual centre of Islam. Berke, having protested against the attack on Baghdad by Hülegü, assured him that with the help of God he would call him to account for so much innocent blood. ${ }^{53}$ In his letter to the Mamluk Baybars, Berke sought an alliance with Egypt against the Il-Khanate. ${ }^{54}$ Berke believed that Hülegü had contradicted the Mongol Yasa, killing the Caliph of Baghdad without consulting the Chinggisid princes. ${ }^{55}$ The actual cause of Berke's anger could have been the execution of three Jochid princes, Tutar, Balaghai and Quli, who had accompanied Hülegü to Baghdad. In fact, in early 1260, Balaghai suddenly died while feasting, Quli died without any specific reason, and Tutar was accused of treason and was executed by Hülegü with Berke's permission. ${ }^{56}$ Besides these motives, the rich pasture and the profitable trade routes of Azerbaijan, held by Hülegü, who considered himself as their possessor

51 Buell, 1999:201.

52 Jūzjānī relates a narrative that Jochi, after the capture of $\mathrm{Kh}^{\mathrm{w}}$ ārazm, requested a Muslim midwife to nurse his newborn son, Berke in order to make him a real Muslim. When Berke reached the age of learning, he was instructed by the 'ulamā to study the Qoran (Jūzjānī, 1970:1283-1284). According to Barthold, the Chaghataid Mubārak Shāh, the son of Qara Hülegü and Orghana Khatun, was the first of the Chinggisids to convert to Islam (Barthold, 1977:483; Jackson, 1978:223-224). For Berke's conversion to Islam, see Vásáry, 1990:231-251.

53 Rashīd al-Dīn, 1954:731; Richard, 1976:173-184.

54 Baybars wrote a letter to Berke in 660 H. (1261-1262). In December 1262, Baybars sent his first embassy to Berke. The embassy returned to Cairo in September 1264. The second embassy was sent soon after, and it returned in 665 H. (1266-1267) (Thorau, 1992:259-260).

55 Rashīd al-Dīn, 1954:731; Lane, 2003:59.

56 Rashīd al-Dīn, 1954:725. 
by right, constantly attracted the Golden Horde, who believed that it was their property. ${ }^{57}$

The Armenian account of the first stage of the war among the Chinggisids provides valuable information documented by Kirakos Gandzakets'i. When the conflict between Berke and Hülegü deepened after the death of Möngke Khan, Hülegü supported Qubilai, and Berke sided with Arïgh-Böke (both candidates were the brothers of Möngke and Hülegü) for enthronement as the Great Khan. An Armenian source states that there was yet another person, the ruler of the Chaghatai Khanate, who was interested in driving away Berke and assisted Hülegü. ${ }^{58}$ Kirakos Gandzakets'i attributes the rise of the conflict between Berke and Hülegü to the Chaghataid Prince Aluqu (r. 1260-1265/1266), who urged the Il-Khan to eliminate Berke. ${ }^{59}$ Therefore, according to the Armenian historian, there was hostility between the Chaghataid and the Golden Horde as well.

In fact, in the course of 1261-1262, many Armenians in Greater Armenia were involved in the Chinggisids' conflict. The young prince Burtel Orbelian died in the North Caucasus, fighting on Hülegü's side against Berke. ${ }^{60}$ Another very important event, the Caucasian lords' rebellion, started in 1259 and lasted until 1261. As has been said above, a year earlier, when Hülegü demanded that the Georgian King David Ulu support his conquest of Syria and Egypt, David, being exhausted from his experience in Baghdad, refused the Il-Khan's order. He ended up in revolt. ${ }^{61}$ While Hülegü was busy fighting on two fronts against the Mamluks and the Golden Horde, Amir Arghun was asked to suppress the Caucasian plot. Due to this action, the Mongols destroyed the Georgian Catholicosate in Atsghor together with many other churches nearby.$^{62}$ As has been mentioned earlier, while David Ulu took refuge at Kutaisi, at his cousin David Narin's court, his family was captured, his wife Gonts'a was drowned and Prince Hasan Jalal was tortured to death by Amir Arghun for

57 Halperin, 1985:27. Berke, as a senior cousin of Hülegü, exercised his power over the latter constantly (Rashīd al-Dīn, 1954:731). This proves that the seniority of the Jochids among the Chinggisids was a principal issue. As has been said above, Hülegü could not cross the Oxus in order to launch the expedition against the Ismāīlīs without Batu's permission and did it only after the death of Batu Khan.

${ }^{58}$ Kirakos Gandzakets'i, 1961:394.

${ }^{59}$ Ibid., 394.

${ }^{60}$ Step'annos Orbelian, 1910:416.

${ }^{61}$ Kirakos Gandzakets'i, 1961:390.

${ }^{62}$ Ibid., 390. 
failure to pay taxes ${ }^{63}$ Prince Zak'arē, the son of Shahnshan Zak'arian, who stayed with Amir Arghun, secretly visited his rebel father-in-law in Ughtik' and was killed on Hülegü's orders for being suspected of having connections with the rebels. ${ }^{64}$ In 1262 , David Ulu returned to his court in Tbilisi (Tiflis), and made peace with the Mongols. In 1263 , at the Il-Khan's request, he dispatched his army to defend the fortification of Siba against the Golden Horde. In 1265, the Caucasian force acting as a vanguard of Abaqa's army defeated Berke and expelled the Golden Horde troops from Shirvan. ${ }^{65}$

As the civil war for the throne between Qubilai and Arïgh-Böke continued until 1264, the antipathy between the fellow cousins, Hülegü and Berke, turned into open warfare. ${ }^{66}$ The Mamluks, knowing through their intelligence that Berke was a Muslim and was antagonistic towards his cousin, were eager to assert the ties with him and his Khanate. ${ }^{67}$ The most important factor in the Mamluk alliance with Berke Khan was the resistance to the Il-Khanate and the maintenance of their institution through the recruitment of young Turkic slaves from the Golden Horde. ${ }^{68}$ In 1262, after the succession of Qubilai who was finally enthroned as the Great Khan, Berke Khan initiated a series of raids, which drew Hülegü north to meet him, and Hülegü Khan suffered a severe defeat in an attempted invasion in the north of the Caucasus in 1263. This was the first open war between Mongols, and signalled the end of the unified empire. ${ }^{69}$

${ }^{63}$ Step'annos Orbelian, 1910:418; Kirakos Gandzakets'i, 1961:390-391.

${ }^{64}$ Kirakos Gandzakets'i, 1961:393; Manandian, 1952:238.

${ }^{65}$ See Chapter 7.

${ }^{66}$ Vernadsky, 2001:158-159.

${ }^{67}$ In total, 50 major embassies of the Golden Horde to Egypt are recorded from the 1260s until 1320. In 1261, Baybars dispatched a letter to Berke persuading him to wage a jihad against Hülegü. The Mamluks employed a special scribe with knowledge of Mongolian and scrupulously followed the Mongol custom and Chinggisid genealogy in their correspondence with Sarai (Halperin, 1985:27).

${ }^{68}$ The Qipchak regiment sent in 1257 by the previous ruler of the Golden Horde, Ulagchi Khan to support Hülegü, was ordered to leave the Il-Khan by Berke. This regiment was transferred to Egypt (more likely in 1261/1262) (Vernadsky, 2001:169). Berke was killed while fighting Hülegü's son, Abaqa Khan in 1266. He was succeeded by his nephew, Möngke-Temür (1267-1280). The policy of alliance with the Mamluks, and containment of the Il-Khanate, was continued by Möngke-Temür. Most historians are in agreement that the intervention by Berke against Hülegü saved Mecca and Jerusalem from the same fate as Baghdad.

${ }^{69}$ Before this, there had been tensions between Batu and Güyük that could have developed into open war as occurred between Berke and Hülegü, but due to the premature death of Güyük in 1248, this did not occur. Also, after this war there were other open conflicts between the Mongols, such as the tension between Arïgh-Böke 
Hülegü's forces were crushed at the river Terek by Berke's nephew Noqai, forcing Hülegü into retreat on 13 January $1263 .{ }^{70}$ While withdrawing across the frozen Terek, many thousands were drowned due to the ice giving way under their weight. ${ }^{71}$ Hülegü with the survivors fled back into Azerbaijan where the Il-Khan began preparations for the renewal of the campaign against the Golden Horde. ${ }^{72}$

Forty-eight years old, Hülegü Khan died on 8 February 1265 in his Winter quarters on the Jaghatu and was buried in the castle on Shāhī Island (on Lake Urmia). ${ }^{73}$ His funeral was the only Il-Khanid funeral to feature human sacrifice.$^{74}$ His chief wife Doquz Khatun, the benefactor of the Christians, died shortly after on 17 June $1265 .^{75}$ Hülegü and Doquz were identified by the Armenian historian as a second Constantine the Great (ca. 280-337) and his mother Helena (d. 330).$^{76}$ Their death was a big loss to the Armenians. Almost a year before they died, in July 1264 (713 Arm.), the Armenian historian Vardan Arevelts'i along with other senior vardapets (masters) had paid a visit to Hülegü, where they saw the Cilician King Het'um, the Georgian King David (Ulu), the Prince of Antioch and 'the Sultans of all over Persia.' Vardan Arevelts'i left a detailed description of his discussions with Hülegü and later, after his death, with his wife Doquz Khatun, in the context of the Christian approach towards

and Qubilai Khan after 1260 and the war between Toqtamysh (1378-1395) and Tamerlane (1336-1405) in the late fourteenth century.

70 Thorau, 1992:124. This war, along with the second raid against Poland, played a key role in the rise of Noqai in the Golden Horde. After Berke's death, Noqai became more and more powerful so that he was a kingmaker to the four subsequent Golden Horde Khans. The Byzantine Emperor Michael VIII Palaeologus (12591282) gave his illegitimate daughter Euphrosyne Palaeologina in marriage to Noqai (Vernadsky, 2001:171-172; Saunders, 1977:73).

${ }^{71}$ Rashìd al-Dīn, 1954:733.

72 The war with Berke was finalised by Abaqa Khan, the son of Hülegü in 1265. Kirakos Gandzakets'i states that these two Mongol Uluses were in a state of war for five years, massing troops against each other and clashing each year, but only during the Winter because of the heat and floods in the Summer (Kirakos Gandzakets'i, 1961:396).

${ }^{73}$ Rashīd al-Dīn, 1954:736.

${ }^{74}$ Boyle, 1968:354; Morgan, 1990:158.

${ }^{75}$ Rashīd al-Dīn, 1954:736.

76 Step'annos Orbelian, 1910:419. The Christian literature both in Syriac (Bar Hebraeus) and Armenian (Step'annos Orbelian) wished to see Hülegü and Doquz Khatun as restorers of Christianity in Mesopotamia, comparing them with the Emperor Constantine and his mother Helena (Borbone, 2009b:102-112; cf. Lane, 1999:1-13). 
good deeds. ${ }^{77}$ In connection with this, Sebastats'i says that the Mongol Il-Khan received Vardan Vardapet with honour and conversed with him on the issues of wisdom. ${ }^{78}$ At the end of his visit, Vardan refused to receive from the Khan any other price or gift than mercy for his people and land. ${ }^{79}$ Furthermore, Vardan advised Doquz Khatun to rear Hülegü's sons, Abaqa and Tegüder in the Christian way. ${ }^{80}$ Hülegü Khan was succeeded by his son Abaqa (r. 1265-1282) and thus he established his line.

To sum up, the death of Möngke prevented Hülegü's further advance in the Near East. For him, possession of Egypt and the Nile was sacrificed in favour of protecting his lands from infringements by his ambitious relatives in nearby Uluses. Oddly enough, the confrontation between two brothers, Qubilai and Arïgh-Böke, for the seat in Qara-Qorum in distant Mongolia, involved two cousins, Hülegü and Berke, in direct conflict. Moreover, with the settlement of Hülegü in Iran, disputes among the Mongol Uluses over the establishment of the frontier lines to include better pastureland became more heated. Hülegü's or the Il-Khanid territories were found to be 'misappropriated' by the Golden Horde. ${ }^{81}$ The conflicts between Mongol Uluses turned into civil war.

This situation within the Mongol Empire reflected MongolArmenian cooperation. The period from 1260 to 1265 was a tense time in relations between the Greater Armenians and the Mongols. After the victory over the Muslims in Upper Mesopotamia and in northern Syria, the Greater Armenian lords found themselves being pressurised by Hülegü's demand that they take part either in his further conquests or in his wars against his Mongol relatives, where they experienced severe casualties.

The initial Mongol-Armenian military collaboration was a great achievement for the Cilician Armenians. Het'um managed to expand his territories even beyond the Cilician boundaries, as had happened in the eleventh century. However, the victory of the Mamluks and defeat of the Mongols in 'Ayn Jālūt was the beginning of the Mamluks' further triumph over the Mongols and a sign of the dashing of

\footnotetext{
77 Vardan Arevelts'i, 1991:157-161.

78 Sebastats'i in Hakobyan, 1956:144.

79 Vardan Arevelts'i, 1991:158.

${ }^{80}$ Ibid., 161.

${ }^{81}$ Jackson, 2005a:125.
} 
Cilician Armenians' hopes to get Mongol help in controlling the Holy Land.

As has been said above, most of the Mamluks were of Turkic descent, as were the inhabitants of Berke's Khanate. Due to Turkic culture, Berke's dominion had much in common with the Mamluks. The attacks by Berke on the Il-Khanate saved the ancient cities of the Holy Land, Mecca and Jerusalem, from suffering a similar fate to Baghdad's. Ironically, Hülegü's conquest brought the Mamluks of Egypt into liaison with the Golden Horde. As a result, the Mamluk Sultanate would rule over the Middle East for more than 200 years, while Berke Khan and his successors would rule in Russia for another 200 years.

The dynasty established by Hülegü would survive the shortest time, only about 91 years, for his descendants to rule Iran and parts of Iraq and Syria, details of which follow. However, the military alliance of the Il-Khans and the Cilician Armenian monarchs would continue with different results until Ghazan Khan's death in 1304. 



\section{MONGOL-ARMENIAN COOPERATION: STAGE III} (1265-1295)

As has been mentioned previously, the Mongol-Cilician Armenian partnership had great success at the beginning. However, conflicts within the Mongol Empire prevented the Mongol advance into the Near East, although the Mongols did not give up the idea of marching on northern Syria. Hülegü's successors made a series of approaches to various leaders to gain Latin support, including the Popes and the Kings of France and England. Meanwhile, the Mamluks became a more and more powerful adversary of the Il-Khanate and their hostility towards Cilician Armenia for being a Mongol ally intensified. The Christian States on the Syrian coast, seeking a chance of survival, saw in the Mongols a realisation of the Popes' dreams of 'Prester John. ${ }^{82}$ Over time, their hopes vanished with the conversion to Islam of the Mongols of the Golden Horde and the Il-Khans. The purpose of this chapter is to discuss the development of Mongol-Armenian military collaboration during the Mongol conquest of the Syrian coast, which eventually grew into a relationship that implicated not only the Mongol Il-Khans and the Armenian lords, but also the Mamluk Sultans and the Christian powers in that particular period.

After the death of Hülegü, the Armenians carefully watched the accession of each Il-Khan and the policy that would follow. The Cilician Armenians tried to use every possible moment to draw the Il-Khans' attention towards their own interests in order to safeguard their lands and rights. In fact, they succeeded in this as long as the Mongols' interest coincided with theirs and remained strong enough to invade the Syrian coast. Examination of the contemporary Armenian sources reveals that the Armenians expected that each Il-Khan would give serious attention to Mongol-Armenian affairs.

${ }^{82}$ The Pope and the King of France were aware of the danger of assisting Mongol armies; however, the Mongols were their only means of breaking the Muslim bondage. The belief in Prester John had grown since 1141, when the Seljuks were defeated by a non-Muslim army from Central Asia, who they thought were Nestorian Christians (Spuler, 1960:29; Jackson, 1999a:711). 
Generally, the Armenian sources are positive towards the Il-Khans Abaqa (r. 1265-1282) and Arghun (r. 1284-1291), mainly due to their sympathy for the Christians. As for the Il-Khans Tegüder Ahmad (r. 1282-1284), Geikhatu (r. 1291-1295), Baidu (1295), Ghazan (r. 1295-1304), Öljeitü (r. 1304-1316) and Abū Sa'īd (r. 1316-1335), the Armenian sources provide rather diverse information. In order to illustrate this statement it is proposed to analyse the historical circumstances under which the Mongols, Armenians and the Mamluks lived and fought.

\section{The Strongest Pairing of Abaqa and Het'um I against Baybars}

Among the Armenian kings of Cilicia, Het'um I (r. 1226-1269) proved himself to be the wisest, most powerful and farsighted monarch. Among the Mamluk Sultans, Baybars al-Bunduqdārī (r. 12601277) was one of the strongest opponents of the Armenians and the Mongols. ${ }^{83}$ Baybars aimed to efface Cilician Armenia from the medieval map. ${ }^{84}$ Among all the Il-Khans, Abaqa's reign (r. 1265-1282) stands out in terms of the entangled nature of his relations with Greater Armenia, Cilician Armenia, the Chinggisids and the Franks. ${ }^{85}$ In addition to this, his diplomacy towards the Mamluks exclusively concerned the questions of the Cilician Armenians.

The relationship between Abaqa and King Het'um I is one of the major defining episodes of Mongol-Armenian collaboration. It was bound to take place after Sultan Baybars al-Bunduqdārī (Tinnı/unum) began his steady advance through Syria to Cilicia. Caesarea, Haifa, Arsuf, Tibnin and Șafad (Safeth) fell to Baybars in

${ }^{83}$ The enlargement and improved training of the Mamluk army along with an efficient espionage system and civilian administration were put into force during Baybars' reign (Amitai, 2005:359-360).

${ }^{84}$ Stewart, 2001:190.

85 Abaqa was the eldest son of Hülegü by Esunjin Khatun, and came to Iran with his father in 1256. According to an Armenian source, he was the most good-looking and well-built among his brothers (Grigor Aknerts'i, 1974:52). Abaqa had 13 (not 30 as Grigor Aknerts'i states) brothers and seven sisters (Rashīd al Dīn, 1954:679). He succeeded to the throne as the Il-Khan of Persia on 19 June 1265. The enthronement took place on the shores of Chaghan Na'ur (White Lake) in the district of Farāhān, to the north of Sulțānābād. However, it was only on 26 November 1270, five years later, that the decree of the Great Khan arrived, and he was enthroned for the second time. Abaqa chose Tabriz as his capital with Summer residences in Ala-Tagh and Siyāh-Kūh, and Winter residences in Baghdad, Arran and in the valley of Jaghatu (Ibid., 742-743, 765). 
1265-1266, signifying the beginning of the end for the Franks in Syria. It was clear that the Sultan would turn on Cilicia, the main ally of the Mongols. ${ }^{86}$ Besides this, it is worth noting that on the eve of the Mamluk advance, the Cilician Armenian economy was flourishing due to foreign trade and manufacturing. The flow of labour increased due to refugees from Greater Armenia and other regions during the 1240s-1250s, who had escaped Mongol pressure. ${ }^{87}$ The wealth of the country surely attracted its neighbours. Cilician Armenian ports on the shores of the Mediterranean Sea made Cilician Armenia participate actively in the international trade of the region. According to Western travellers, the most important port was Ayas, where spices and food of all sorts, silk and woollen goods and other rich commodities were traded. ${ }^{88}$ Therefore, control over Ayas would challenge the Sultans constantly. ${ }^{89}$

Seeing the growing aggression of the Mamluks, King Het'um I tried on his own to negotiate a peace treaty with Baybars, for which, as Smbat Sparapet records, some embassies were exchanged, but the Sultan was too demanding. ${ }^{90}$ Het ${ }^{\prime} u m$ refused to accept the conditions surrounding certain frontier holdings. This can be explained for two reasons. Firstly, the Armenian monarch was afraid of the anger of the Mongols, who would blame him for having fallen under the influence of the Sultan if he gave him the fortresses the Mongols had captured. Secondly, the Sultan wanted Het'um to give him a less ruined frontier holding called Shih $(\tau h h)$ with a view to making it a marketplace for trade. Het'um could not accept these conditions, because allegedly 'he had been a victorious and famous King for many years, while the Sultan who had been the servant of disreputable servants had later become so powerful that all feared him. ${ }^{.91}$ As Grigor Aknerts'i suggests, there was another motive as well. Muslim advisers at the court of Abaqa Khan were secretly seeking ways to undermine Mongol trust in the Cilician Armenians. These advisers wrote to the Sultan of Egypt telling him to obtain at least one village

\footnotetext{
${ }^{86}$ Smbat Sparapet in Galstyan, 1962:59; Der Nersessian, 1973:373.

${ }^{87}$ Mikaelean, 1952:339, 346.

${ }_{88}$ Marco Polo, 1987:20.

${ }^{89}$ Stewart, 2001:187.

90 Smbat Sparapet in Galstyan, 1962:59; Der Nersessian, 1973:374.

91 Smbat Sparapet in Galstyan, 1962:59-60.
} 
from the Armenian King, which would be sufficient reason to claim that the Armenian King had breached his vow with the Mongols. ${ }^{92}$

For many reasons, the position of Cilician Armenia became precarious and there was sufficient reason for Het 'um to rush to seek Mongol help in $1266 .{ }^{93} \mathrm{He}$ divided his forces into three groups: one he took with him; the second was stationed at a place called the Gate $\left(7 n\left\llcorner n\{)\right.\right.$; while the third was at a place called Mari (Marrī).${ }^{94}$ In his absence, Baybars sent the Mamluk army under the command of his amirs to cross the Amanus Mountains and enter Cilicia as far as Sis, Adana and Bardzraberd. ${ }^{95}$ Smbat Sparapet with the two young princes, T'oros and Lewon, led the Armenian forces against the Mamluks at Mari but were routed. T'oros was killed; Lewon and Smbat's Mongol son Vasil were captured and sent to Egypt. ${ }^{96}$ When Het'um returned two days ahead of the Mongol troops who had been sent to aid him, he found Sis set on fire, the port of Ayas devastated and the whole country destroyed.$^{97}$ Serious damage was done to the Cilician economy, for which the lords of Cilician Armenia blamed Het'um, claiming that by his refusal to hand over to the Mamluks a fortress at Shih had brought their whole country to misfortune and cost him the loss of his sons. ${ }^{98}$

T'oros' death and Lewon's capture led Het'um to seek help from the Papacy. This was one of five appeals by the Cilician Armenian kings written to Western kings and the Papacy for aid and support against Egypt. ${ }^{99}$ Pope Clement IV (1265-1268), who had encouraged Het'um to assist the Syrian crusaders earlier on, expressed his condolences and asked the Byzantine Emperor to help the Cilician Armenians, but Michael VIII Palaeologus was not remotely interested in doing so. ${ }^{100}$

92 Grigor Aknerts'i, 1974:59.

${ }^{93}$ Grigor Aknerts'i says that King Het'um went with a small detachment to the Mongols who were stationed between Abulistan and Kokoson (Grigor Aknerts'i, 1974:54).

94 Smbat Sparapet in Galstyan, 1962:60.

95 Het'um Patmich', 1956:73; King Het'um II, 1962:73; Der Nersessian, 1973:373-374; cf. Thorau, 1992:192-193.

${ }_{96}$ Smbat Sparapet in Galstyan, 1962:60-61; Het'um Patmich', 1956:73; Boase, 1978:26.

${ }_{97}$ Grigor Aknerts'i, 1974:54; Sebastats'i in Hakobyan, 1956:145-146; Vahram, 1831:50-51.

98 Grigor Aknerts'i, 1974:59.

99 Lloyd, 1988:25.

${ }^{100}$ Mikaelean, 1952:344; Richard, 1992:516-517. 
His refusal had its own reason. It was connected to Abaqa's marriage, a political affair that involved many parties. Abaqa was given a Christian wife, Maria Despina Palaeologina in $1265 .{ }^{101}$ This marriage was blessed by the Patriarch of Antioch, by Sargis, the Bishop of Erznka, and someone called Vardapet Bener, ${ }^{102}$ exemplifying the positive character of the Christian clergy towards Christian marriages with the Mongols. This marriage alliance with the imperial dynasty of Constantinople was part of a series of political actions that involved many parties in double-dealing. Firstly, it could be interpreted as one of the Il-Khan's tactical moves to find an ally and to secure the Il-Khanid position, which was threatened by the Golden Horde and its coalition with the Mamluks. Secondly, it provoked Sultan Baybars, who was carefully watching the outcome of the alliance between the Il-Khanate and Michael VIII, and was anxious about the Il-Khan's relations with the Franks, to pursue measures that would counter the Il-Khanate-Byzantine union. Berke of the Golden Horde persuaded his victorious nephew Noqai (d. 1299) to marry another illegitimate daughter of the Emperor Michael VIII, Euphrosyne Palaeologina, in 1266. ${ }^{103}$ In this way, the Golden Horde was supported by both Egypt and Byzantium. As for the Byzantine Emperor, this decision to marry his daughters to Abaqa and Noqai was a serious attempt to play a twofold game out of concern for his own position in the region. This was surely a political action, which to some extent supports Saunders' definition of a Mamluk-Qipchak-Byzantine alliance against the Il-Khanate and the Latins. ${ }^{104}$ In fact, Michael VIII himself had no desire to see the power of the Franks growing in the Levant or to share his business on trade routes. The Byzantine Emperor, who

101 Step'annos Orbelian, 1910:470. The Byzantine Emperor Michael VIII Palaeologus (1261-1282), who had controlled the truncated Byzantine realms from Nicaea since 1259, was actually frightened when one of the two joint Seljuk rulers, Izz al-Dīn, was dethroned by Hülegü in 1262, and fled to Constantinople. In order to assure his friendship towards the Il-Khan, Michael offered him his illegitimate daughter in marriage (Saunders, 1977:70-71). However, Maria arrived after his death, so she was given to his successor (Jackson, 1999b:710; Nicol, 1993:80-81).

${ }^{102}$ Kirakos Gandzakets'i, 1964:399.

${ }^{103}$ Lamb, 1940:249; Nasonov, 1940:44; Vásáry, 2005:79. Noqai controlled the western frontiers of the Golden Horde. In 1265, he led his army across the Danube, making the Byzantine forces flee, and devastated the city of Thrace. Therefore, this marriage was important for the Emperor. Vernadsky dates it to 1273 (Vernadsky, 2001:172). In 1286, Noqai plundered Poland mainly for provisions (De Hartog, 1996:70).

104 Saunders, 1977:74, 1971:131. 
expelled the Franks from Constantinople in 1261, was apprehensive of every new crusade. ${ }^{105}$ Therefore, to prevent new assaults on Constantinople, he decided to court both the Mamluks and the Golden Horde. In addition to this intrigue, Baybars made another attempt at a Byzantine-Mamluk alliance against the Il-Khanate and the Frankish states. He opened up commercial relations with Genoese merchants for a slave trade via Constantinople. ${ }^{106}$ The Emperor offered Baybars the territories and sea-routes that were under his own control, so that the Golden Horde and Egypt could communicate with each other through diplomatic missions, the slave trade, the most profitable commerce of that time, and by other means. ${ }^{107}$ Therefore, the Emperor's interests did not coincide with those of the Pope and the Armenians. However, the Emperor could not neglect his relationship with the Il-Khan. In 1263-1265, Michael Palaeologus held up the Sultan's envoys to Berke only because he was afraid that Hülegü would suspect him of assisting his enemies' passage. ${ }^{108}$

This situation prompted Het'um to initiate a series of diplomatic interactions with Baybars in order to negotiate conditions for Lewon's return. ${ }^{109}$ In 1266, the Armenian ambassador was received by Baybars in Cairo. In 1267, the second mission of Het'um was sent to meet the Sultan in Syria. ${ }^{110}$ According to the Armenian and Mamluk sources, it is likely that Het' um at the outset offered both money and several landholdings to Baybars, who in his turn also demanded the forts taken by the Mongols in 1260 along with the release of his friend Sonqur al-Ashqar who was in Mongol captivity. ${ }^{111}$ Now the Mongols were the only supporters of Het'um's deal. Het'um had no problem in convincing Abaqa because the Il-Khan himself was interested in establishing a good relationship with Baybars. Earlier on, in 1265-1266, Abaqa sent his first embassy to the Sultan with a present

105 Zakirov, 1966:27.

106 Thorau, 1992:121.

107 Saunders, 1977:71-73.

108 Tizengauzen, 1884(Vol. 1):190; Nasonov, 1940:41.

109 Smbat Sparapet in Galstyan, 1962:61.

110 Ibid., 62; Amitai-Preiss, 2004:118.

111 Sonqur, whose name is spelled in Armenian texts as Sghur $\left(\boldsymbol{U}_{\boldsymbol{\eta} \boldsymbol{n} \iota \boldsymbol{\eta}}\right.$, Grigor Aknerts'i, 1974:61), or Sngurashkhar (Smbat Sparapet in Galstyan 1962:62), was a colleague (khushdāsh) of Baybars who helped the latter to escape from the Mongols in the battle for Aleppo, giving him his fine horse while himself mounting a poor horse of Baybars' (Grigor Aknerts'i, 1974:61; Smbat Sparapet in Galstyan, 1962:61; Amitai-Preiss, 2004:118). 
and 'calling for peace,' which meant a peaceful submission. ${ }^{112}$ Seemingly, this act had no result. However, in 1267, Het'um himself went to Abaqa's court but was told that the Mamluk prisoner Sonqur al-Ashqar was not to be found. ${ }^{113}$ In 1268, Lewon, the son of Smbat Sparapet, was sent to the Mongols to ask Abaqa's permission to look for Sonqur al-Ashqar among the soldiers stationed in remote garrisons. ${ }^{114}$ Finally, Sonqur al-Ashqar was found married to a Mongol wife with several children. ${ }^{115}$ With the help of Abaqa Khan and an agreement to give the Mamluks six important fortresses in addition to an exchange of prisoners, Het'um finally secured the release of his son Lewon, who had been held for one year and ten months in captivity in Egypt. ${ }^{116}$ Strangely enough, the Armenians brought two adversaries, Abaqa Khan and Sultan Baybars into diplomatic contact. ${ }^{117}$

The Armenian King decided to exploit further this diplomatic contact established between two sovereigns. After the conquest of Aleppo, Hülegü had taken prisoner some other Bahrī Mamluks. Baybars kept other Armenian prisoners in captivity. The children of Sonqur al-Ashqar were left with the Mongols. Het'um, knowing this and realising that he could reinstate his weakened authority only if the Mamluks and the Mongols, two equal powers in the region, ended their mutual hostilities, offered himself as an intermediary, peacemaker and negotiator with the Mongols in his letter to Baybars written in 1268. ${ }^{118}$ The Sultan permitted the Armenian King to deal on behalf of Sonqur al-Ashqar with the negotiations concerning only the children. Het'um somehow misled Abaqa Khan about the Sultan's message, and Abaqa understood that the Sultan agreed to submit to the Mongols and agreed to the release of the Bahrin Mamluks. ${ }^{119}$ The Il-Khan sent his verbal message through the official envoy via Cilicia. A letter written in December 1268 in Baghdad followed. In his answer, Baybars stated that the Armenian King had no right to deal

112 Amitai-Preiss, 2004:120.

113 Smbat Sparapet in Galstyan, 1962:62.

114 Ibid., 62.

115 Amitai-Preiss, 2004:120.

116 Grigor Aknerts'i, 1974:61; Het'um Patmich', 1956:74.

117 The involvement of Het'um in the exchange of envoys and letters between Abaqa and Baybars, based on Mamluk sources, was examined by Amitai-Preiss, 2004:120-122.

118 Amitai-Preiss, 2004:120-121.

119 Ibid., 121-22. 
with any other matters except Sonqur's children, and having reminded Abaqa about Ket-Buqa's defeat in 'Ayn Jalūt, he refused to submit. ${ }^{120}$ The Armenian monarch and the Mongol Il-Khan were taught a lesson that their opponent was more powerful than they thought. Consequently, Abaqa did not achieve any peace-treaty with BaybarsIf the Mamluks were the only main adversary of the Armenian King, there was another important matter for the Il-Khan to deal with constantly. This was warfare among the Chinggisids in which Greater Armenia was involved.

\section{Greater Armenia and the Struggle with the Golden Horde}

Once settled on the throne, Abaqa appointed commanders and officials all over his domains. Georgia and Greater Armenia were placed under the supervision of Shiramun, the son of Chormaghan. ${ }^{121}$ Shams al-Dīn Juvaynī retained the office of vizier. His brother 'Ala al-Dīn 'Ata-Malik Juvaynī, the historian, who was previously the governor in Baghdad in Hülegü's time, became a lieutenant to Sunjaq Noyan, the governor of 'Irāq-i 'Arab and Fārs. The Juvaynī brothers aimed to transform Mongol rule into the old model of Iranian kingship. The revival of Takht-i Sulaymān, the Iranian pre-Islamic site of the kings, was part of their scheme to represent Mongol rulers as the heirs of the Sassanians. ${ }^{122}$ As for Greater Armenia, as has been said earlier, the Zak'arian House had lost its leading role to the Artsrunids. Sadun Artsruni was appointed as atabeg of Georgia by Abaqa Khan. ${ }^{123}$ Being unable to pay taxes to the Il-Khanid court, Shahnshah Zak'arian had to trade a part of the city of Ani to Shams al-Dīn Juvayni in 1263. ${ }^{124}$ The latter befriended Sadun Artsruni and was married to Sadun's protégée Khoshak, the daughter of Awag Zak'arian and Gontsa. Although the Zak'arids were in decline, this marriage gave the Zak'arids a chance to reinstate the dignity of their House. ${ }^{125}$ Beside the Artsruni family, the House of Orbelian gained a strong position through Prince Tarsaich, the favourite of Abaqa. ${ }^{126}$ Other

\footnotetext{
${ }^{120}$ Ibid., 122.

121 Rashīd al Dīn, 1954:743.

${ }_{122}$ Melville, 2003a:54.

${ }^{123}$ Step'annos Orbelian, 1910:418; Melikset-bek, 1936:60.

${ }_{124}$ Babayan, 1976:633.

${ }^{125}$ Ibid., 633.

${ }^{126}$ Step'annos Orbelian, 1910:423.
} 
important families were the Dop'ians, the Vach'utians and the Vakhtangids. ${ }^{127}$ These families were in the service of Abaqa for his expeditions to Syria and fought with him against the Chinggisids of the Golden Horde and the Chaghatai Ulus.

The Golden Horde actively involved Abaqa in military conflicts from the very beginning of his reign until 1267. When the Il-Khan renewed his fight with Berke in the territories of the Caucasus, this time on the shores of the River Kur in Georgia, the Caucasus was again involved into Mongol warfare. ${ }^{128}$ The Armenian and Georgian farmers were the primary victims of this action, since they were obliged to feed and accommodate one or other party of the Mongol Khans. ${ }^{129}$ Although the battle ended victoriously for Abaqa, leaving Noqai to lose one eye and Berke to die from sickness on his way to Tiflis in $1266,{ }^{130}$ the Greater Armenian economy deteriorated greatly. ${ }^{131}$

In addition to the Golden Horde, constant hostilities from the Chaghatai Khanate ${ }^{132}$ towards the Il-Khanate became another challenge for the Armenians. When Abaqa defeated the Golden Horde, Baraq Khan (r. 1266-1271), the ruler of the Chaghatai Khanate, tried to take over Iran. ${ }^{133}$ Another grandson of Chaghatai, called Tegüder or Negüder (fl. 1266-1269, not to be mistaken for Il-Khan Tegüder Ahmad), who came to Iran with Hülegü and stayed with Abaqa in his ordu (headquarters) along with his one tuman of cavalry men, was provoked by Baraq to rebel against Abaqa Khan in 1268. ${ }^{134}$ When Tegüder left Abaqa for his own fief in Gurjistan vilayet, from where through Derbent he aimed to join Baraq, the Il-Khan sent Shiramun,

127 Babayan, 1976:634.

${ }^{128}$ Kirakos Gandzakets'i, 1964:399. Rashīd al-Dīn states that the army of Noqai crossed the River Kur and the actual battle occurred on the shores of River Aksu which the Mongols called Chagan Moren (White River) (Rashīd al-Dīn, 1954:744).

129 Bedrosian, 1996:133.

${ }^{130}$ Rashīd al-Dīn, 1954:744.

${ }^{131}$ Manandian, 1952:301.

132 The Mongol Empire in Turkestan.

${ }^{133}$ Baraq, as a descendant of Chaghatai, was disappointed that the Toluids, Qubilai and Abaqa held better pastures and bigger lands. After a council with Qaidu, the grandson of Ögedei, and Möngke-Temür, the great-grandson of Jochi, Baraq decided to invade Iran. He also resolved his earlier conflicts with Qaidu, regarding the lands of Mā warā' al-nahr, and the lands between the rivers of Syr Darya and Amu Darya, giving Qaidu and Möngke-Temür one-third of these lands and keeping two-thirds for himself (Rashid al-Dīn, 1954:749; Biran, 1997:57).

${ }^{134}$ Rashīd al-Dīn, 1954:749. 
the son of Chormaghan, who was in charge of the Caucasus, to pursue Tegüder. ${ }^{135}$ According to the description of Grigor Aknerts' $i$, Tegüder was fond of wealth and was thus prone to pillage and slaughter. ${ }^{136}$ For this reason, Georgian-Armenian forces under the standard of the Il-Khan fell on Tegüder's troops and mercilessly slaughtered them. They took all of his treasures. ${ }^{137}$ Tegüder surrendered in the Autumn of 1269 in a forest in Georgia and was imprisoned for a year on the island on Lake Urmìya (Darīa-ye Kabūdān) and then released after Baraq's death. ${ }^{138}$

In the meantime, Baraq Khan claimed the meadowlands of Badghīs in Herat, which belonged to Tübshin, the youngest brother of Abaqa. Tübshin, with the assistance of Arghun Aqa (Amir Arghun), was unable to oppose Baraq and retreated to Māzandarān to await Abaqa's main army. Baraq made his headquarters in the Țāliqān area and succeeded in taking the greater part of Khurasan. After pillaging Nīshāpūr, Baraq was about to conquer Herat but Abaqa, through trickery, made Baraq withdraw his forces to the banks of the River Harī, where the battle (called the Battle of Herāt) between the Il-Khanate and the Chaghatai Ulus commenced in July $1270 .{ }^{139}$ Baraq escaped across the Oxus but afterwards he was paralysed by fear that Qaidu would destroy him and died. ${ }^{140}$

Being victorious in the battles against the Golden Horde and the Chaghatai Ulus, Abaqa Khan himself did not take any major part in military action afterwards. ${ }^{141}$ Rather, he was keen to secure his own empire by restructuring the imperial taxation and monetary policy. ${ }^{142}$ Nonetheless, the western frontiers of his domain were constantly troubling him.

${ }^{135}$ Ibid., 750; Babayan, 1976:632.

${ }^{136}$ Grigor Aknerts'i, 1974:63.

137 Ibid., 64.

${ }_{138}$ Rashīd al-Dīn, 1954:750.

139 Ibid., 755-765; Biran, 1997:62-63, 2002:175-219. For the ode on the restoration of Nishapur, see Minorsky, 1964d:292-305.

140 Rashīd al-Dīn, 1954:755-765. On Qaidu, see Biran, 1997.

${ }^{141}$ In 1271, the Ismā' îlī stronghold Girdkūh finally surrendered (Rashīd al-Dīn, 1954:766).

${ }^{142}$ For numismatic evidence for these reforms, see Kolbas, 2006:193-234. 


\section{Lewon III and Abaqa against Baybars}

Het'um I, seeing that the Mamluks had stormed Antioch and that many refugees had escaped to Cilicia, and that, after a severe earthquake in Cilicia, many places were in ruin, ${ }^{143}$ he abdicated in 1269 in favour of his son Lewon III (r. 1269-1289) and retired to a monastery. But before becoming a monk called Makar, ${ }^{144}$ Het ${ }^{\text {'um sent }}$ Lewon to Abaqa Khan to acknowledge and introduce his son as the next Cilician Armenian king. The Il-Khan Abaqa confirmed his position, ${ }^{145}$ and a year later, in 1270, after a reign of 44 years, King Het'um I died. ${ }^{146}$

The strongest phase of Mongol-Armenian military collaboration was continued by Lewon and Abaqa. When in 1271, Lewon III was anointed king in the Church of St. Sophia at Tarsus, ${ }^{147}$ Baybars set out for Cilicia again to challenge the new king; however, King Lewon, proving that he was a capable ruler, sent a mission to negotiate, and Baybars returned to Egypt. ${ }^{148}$ Meanwhile, Lewon rushed to Abaqa Khan, who offered him 20,000 men to safeguard Cilician Armenia and promised that he would himself come to Cilicia a few months later. Apparently, Lewon returned home taking with him Abaqa's soldiers. ${ }^{149}$

In 1274, King Lewon sought the help of the Mongols again. The wealthy Greek princes of his kingdom were plotting against the Armenian kingship in Cilicia, demanding that the latter profess their faith. King Lewon seized some of them and dispatched them to Abaqa Khan who executed them. ${ }^{150}$ Next year, in 1275, the Mamluks again attacked the coastal plain of Cilicia. ${ }^{151}$ The Arab sources, Ibn Shaddād and Mufaḍdal, justify this invasion as a response to provocation by Mu'in al-Dīn Sulaymān Pervāne, the Rūmi Seljuk, who

\footnotetext{
${ }^{143}$ Smbat Sparapet in Galstyan, 1962:62-63.

${ }^{144}$ Vahram, 1831:53.

145 Smbat Sparapet in Galstyan, 1962:63-64; Het'um Patmich', 1951:57.

${ }^{146}$ Het'um Patmich', 1956:75. For different dates of the king's death, see Akinean, 1948:278-279. The Georgian King David Ulu also died in the same year (Grigor Aknerts'i, 1974:62; Step'annos Episkopos, 1951:44).

${ }_{147}$ Smbat Sparapet in Galstyan, 1962:64. In one of the colophons written in 1275 in southern Armenia, the Cilician King Lewon III was considered as the King of all Armenians (RHC/DA, 1869[Vol. 1]:606; Mikaelean, 1952:348).

148 Smbat Sparapet in Galstyan, 1962:64.

149 Ibid., 64.

150 Grigor Aknerts'i, 1974:66.

151 Sebastats'i in Hakobyan, 1956:146.
} 
invited Baybars to take his chance over Rūm, but suggested the Mamluk Sultan neutralise the Cilician Armenian Kingdom first. ${ }^{152}$ Bar Hebraeus records that Lewon understood that Baybars would be interested in invading Rūm (in 1277) and in having access to Caesarea via Cilicia. Therefore, he repeatedly warned the Mongols about this threat but without any success. ${ }^{153}$ Another motive for this incursion was the discontinuation of the tributes paid by the Armenians to the Sultan. Baybars considered this as a breach of the Armenian-Mamluk treaty, the exact conditions of which are not known. ${ }^{154}$ Whatever the precise reason may have been, the Mamluks started their raids in Cilicia. Through his intelligence network, Baybars knew that Abaqa was too busy on his eastern borders and there was no significant Mongol force in Cilicia. ${ }^{155}$ The Mamluks devastated Marash as a prelude to their main campaign, and having no actual battle with the Mongols to bar his way, Baybars entered the capital Sis via the Syrian Gate in March $1275^{156}$ (see Map 2). Bar Hebraeus asserts that the Mamluks reached as far as Korikos (Gorycus) by killing, plundering and burning. ${ }^{157}$ There was another minor raid by some Seljuk amirs sent by Baybars to Cilicia in 1276, from the direction of Marash, which was successfully repulsed, although Smbat Sparapet was killed along with many other Armenian nobles in this battle. ${ }^{158}$ In 1277, from Syria, Baybars raided Abulistān (Abulustayn, Elbistan), the territory of the Rūmi Seljuks, and having defeated the Mongol army commanded by three amirs, he came to Caesarea. ${ }^{159}$ In the same year, in Ala-Tagh the Mongols killed Mu īn al-Dīn Sulaymān Pervāne and many of his army, who had supported Baybars. ${ }^{160}$ Although King Lewon III did not receive much Mongol assistance, he continued his father's pro-Mongol policy. However, he looked upon Western help as well. In 1278, Lewon's envoys came to Edward I of England (r. 1272-1307). The precise purpose of their visit is unknown. Lloyd

152 Stewart, 2001:50-51. On Pervāne's activity in Anatolia, see Melville, 2009:51101.

153 Bar Hebraeus, 2003:456-457.

154 Amitai-Preiss, 2004:134; Stewart, 2001:50.

155 For the Mamluk intelligence network, see Amitai-Preiss, 2004:139-152.

156 Thorau, 1992:233; Amitai-Preiss, 2004:134-135.

157 Bar Hebraeus, 2003:453.

158 Ibid., 454; Thorau, 1992:237.

159 Melville, 2009:51-101.

160 Step'annos Episkopos, 1951:45; Rashīd al-Dīn, 1954:768; Het'um Patmich', 1951:55-56. 
suggests that it was probably connected with securing Edward's aid or a crusading vow. ${ }^{161}$ Nevertheless, it is certain that Lewon believed that the Latin alliance with the Mongols would save not only his own realm, but also the Holy Land.

\section{The Mongols' Appeal to Latin Christendom}

It was not only the Armenians who sought Latin support. ${ }^{162}$ The Mongol Il-Khans were the most active Chinggisids to address the Western powers. Their main reason to do so was related to the political circumstances that the Il-Khanate experienced. The division of the Mongol Empire into Uluses (independent appanages), the intensification of hostilities among them and thus the raids of the Golden Horde on the frontier pastures of Azerbaijan through the Caucasus certainly provoked the Il-Khans. These ventures made the Il-Khans consider their status. Their target was again Palestine and Syria, despite the fact that their previous experience showed them that the climate and pasture of these areas were not suitable for the Mongols. Scholars agree that the capacity of Syria to feed a large Mongol army was limited. Leaving this notion aside, to which we will return later, a brief introduction to the Mongol efforts in trying to achieve Latin support over Syria merits attention because these actions touched the Armenians' sore spot.

Hülegü and his successors pursued the idea of invading Syria, although for different reasons. However, they realised that, without Western involvement, they could not make any progress. They also believed in playing on the sensitivities of the Christians in regaining the Holy Land. Hülegü was the first Il-Khan to write a letter to the French King Louis IX in $1262 .{ }^{163}$ He sought the French King's assis-

\footnotetext{
161 Lloyd, 1988:254.

162 Matthew Paris (ca. 1200-1259), an English chronicler, left an account dated as early as 1249, of the Mongol embassy that requested Latin support against the Muslims. He referred to a Mongol embassy sent by General Eljigidei (Eljidei) to the French King Louis IX (1226-1270) in December 1248 (Matthew Paris, VI, No.84). The Mongols had proposed simultaneous operations against the Muslim powers long before the establishment of the Il-Khanate (Lloyd, 1988:261; Jackson, 2005a:98-99; Amitai-Preiss, 2004:15). On Eljigidei and his mission, see Jackson, 1980:483-484, 1998:366; Richard in Aigle, 1997:57-69).

${ }^{163}$ Earlier, in 1246, and 1247, some letters had been exchanged between Pope Innocent IV and Güyük Khan and between the Pope and Baiju Noyan in 1247 (Lupprian, 1981:182-198).
} 
tance for a French naval fleet to blockade Egypt against the Mamluks. ${ }^{164}$ The letter had no result. On the contrary, Frankish embassies from Jerusalem, Cyprus, Italy and Sicily were sent to Baybars with an aim to maintain good relations with Cairo. ${ }^{165}$

The Il-Khan, Abaqa, had been sending letters to the Pope since 1266/1267. His increasing interest in Syria may have been based on a notion of achieving positive results with the West. Being aware of the planned Crusade, Abaqa dispatched envoys in early 1267 to Pope Clement IV (1265-1268) and to James I of Aragon (1213-1276). ${ }^{166}$ In his reply to the Pope in 1268, Abaqa Khan agreed to send troops under the command of his brother Ejei (Hegei/Adjai) to aid the Eighth Crusade. ${ }^{167}$ The recent fall of Antioch to Baybars in 1268 had forced Abaqa to make several decisions. In September 1271, after unsuccessful attempts to meet Louis IX (r. 1226-1270) in 1268 and 1269 and Philip III (r. 1270-1285 in 1270, Abaqa asked Lord Edward, the future King Edward I of England, to undertake simultaneous actions against the Mamluks. ${ }^{168}$ Edward, who arrived in Palestine with a contingent insufficient to carry on the crusading tradition, may have realised that the West needed to ally with the Mongols. ${ }^{169}$ He sent his envoys, Reginald Russell and John Parker, to Abaqa in order to arrange for joint military action against Baybars. ${ }^{170}$ These actions, however, took place with no result for either side. ${ }^{171}$ Despite the failure of military collaboration with Edward's crusade, Abaqa continued his policy to drive out the Mamluks from Syria by continuously appealing to the Latin powers. In 1273, he once more wrote letters both to the Pope and to Edward I of England. Abaqa's envoys, David of Ashby, the papal legate in Palestine and Abaqa's Latin inter-

164 Meyvaert, 1980:245-259; Jackson, 2005a:166.

165 Thorau, 1992:193-196.

166 Lupprian, 1981:220-225; Jackson, 2005a:167.

167 Jackson, 2005a:167.

168 Ibid., 167; Richard, 1983:34-35.

169 Dawson, 1955:xxvii. Edward lacked manpower. According to Smbat Sparapet, King Edward came to Acre by boat with 2,000 men (Der Nersessian, 1973:376).

170 Dawson, 1955:xxvii. Baybars commissioned his agent to arrange for Edward's murder. On the pretext of seeking baptism, a certain Assassin was deployed. According to the Armenian chronicle, Edward was stabbed five times, but recovered from the dagger wounds (King Het'um II, 1962:74). Immediately after this failure, Baybars sent an embassy to Edward expressing his regret at the attack and denial of his involvement (Thorau, 1992:221-222).

171 Abaqa was involved in the war with the Chaghatai Khanate (Richard, 1976:43-54). 
preter Richardus repeated the message at the Council of Lyons, summoned by Pope Gregory X (1271-1276) in 1274 in order to plan a new crusade. ${ }^{172}$

Despite being invited neither Armenians from Cilicia, nor from Greater Armenia were present at this Council. ${ }^{173}$ Scholars consider that during the period of the Mongol-Armenian alliance, especially from 1260 to 1288, the Armenian Church became less susceptible to the demands of Rome. Having gained security from association with the powerful Mongols, the Armenian Church felt no need to remain in union with the Church of Rome and thus it declined to be present at the Council of Lyons. ${ }^{174}$ This also explains the bold assertion of Mkhit'ar Skewrats'i, at the meeting at Acre with the Pope's legate, Bishop John of Jerusalem, about Armenian ecclesiastical independence from Rome. Mkhit'ar Skewrats'i questioned why the Church of Rome had the authority to judge other apostolic sees and why it could not be judged by others, and since the Armenians had full powers to judge Rome, the Roman Church could not criticise them for doing this. ${ }^{175}$ Undeniably, this argument played a crucial role in the deterioration of the good relationship between the Roman and Armenian Churches; however, it was clear that Mongol backing emboldened the Armenian Church. ${ }^{176}$

In 1275, the Mongol ambassador David of Ashby visited King Edward I and in 1277, he was in Italy. ${ }^{177}$ Abaqa received no positive reply from either the Papacy or from France or England. Since Abaqa had not succeeded in eradicating the Mamluks with the help of the West, he decided to act alone. In 1277, Baybars I died at Damascus on his way back from the invasion of the Seljuks of Rūm. ${ }^{178}$ Having been defeated by the new Sultan Qalāwūn (r. 678-689 H. / 12791290), Sunqur, a former prisoner of the Mongols, wrote Abaqa a letter informing him of the disunity within the Sultanate and offering the Khan his help in invading Syria. ${ }^{179}$ According to Arabic sources, in the Summer of 1280, Abaqa sent his brother Möngke-Temür, a

${ }^{172}$ Lupprian, 1981:226-230; Roberg, 1990:285-286; Richard, 1976:46-57.

173 Pogossian, 2006:288.

174 Bundy, 1996:39; Pogossian, 2006:288.

175 RHC, Arm, 1, 691-698.

176 Bundy, 1996:39.

177 Jackson, 2005a:168.

178 Amitai-Preiss, 2004:177-178.

179 Ibid., 182. 
young and inexperienced commander, to Syria. ${ }^{180}$ Möngke-Temür entered Syria with a large army and reached as far as Aleppo. ${ }^{181}$ Before sending his last embassy to Edward I, in 1280, Abaqa had demanded that Latin military forces and provisions be supplied from Acre. ${ }^{182}$ Only the Cilician Armenian King Lewon III joined him with his troops, along with Bohemond VII of Tripoli. The Latin West was represented by some Hospitallers from Margat (Marqab). ${ }^{183}$ Sultan Qalāwūn left for Syria in November 1280 and positioned his army between Möngke-Temür and the Franks on the coast. ${ }^{184}$ Reaching Gaza, the Sultan was informed that Möngke-Temür had looted the city and had withdrawn from the country. Qalāwūn decided to go back to Egypt. ${ }^{185}$ The notion of the desecration of Muslim sanctuaries by the Cilician Armenians is again found in Arabic sources. According to Mufaḍdal, the Great Mosque of Aleppo was set on fire by the Armenians of Sis. ${ }^{186}$ As has been said before, the first burning of the Great Mosque was attributed to King Het'um I in 1260. ${ }^{187}$

In September 1281, Möngke-Temür along with Generals Alinaq, Taiju-Bahadur, Tukna and Doladai headed for Syria again. ${ }^{188}$ Abaqa Khan set out after Möngke-Temür a month later and reached Erznka, where he was informed that the army of the Golden Horde had passed the Derbent Gate, so he hurried home without helping his brother. ${ }^{189}$ The Mongol army of 50,000 Mongols and 30,000 Armenians, Georgians, Franks and Seljuks marched through Abulustayn and reached as far as 'Ayn Țāb. ${ }^{190}$ The battle with the Egyptians took place near Homs on 29/30 October. ${ }^{191}$ King Lewon commanded the Mongol right wing, comprised of Armenians and Georgians. ${ }^{192}$ They

\footnotetext{
${ }^{180}$ Ibid., 183.

181 Amitai-Preiss, 2004:184.

182 Jackson, 2005a:168.

${ }^{183}$ Ibid.

${ }^{184}$ Ibid.

185 Amitai-Preiss, 2004:185.

186 Stewart, 2001:54.

187 See Chapter 5.

${ }_{188}$ Rashīd al-Dīn, 1954:778.

189 Sebastats'i in Hakobyan, 1956:147.

190 Stewart, 2001:54. It is 30,000 men in total in Het'um Patmich', 1951:57.

${ }_{191}$ On the battle formation, size of the armies and losses, see Amitai-Preiss, 2004:187-201.

${ }^{192}$ Het'um Patmich', 1951:58. The Georgians were commanded by Dimitri (King Demetrē, 1270-89) (Amitai-Preiss, 2004:189).
} 
drove back the left wing of the Egyptians to the gate of Homș. ${ }^{193}$ Nevertheless, in the centre, Möngke-Temür was wounded and turned back with the greater part of his army to Upper Mesopotamia. The Armenian King was surprised that Möngke-Temür left the battlefield but he followed him, being mercilessly attacked by the Mamluks. It caused him to lose more than 2,000 men. ${ }^{194}$ Besides the Cilician Armenians, according to Step'annos Orbelian, among the Mongol troops were the forces of Greater Armenia under the command of Tarsaich Orbelian and they fought in this and previous Mongol battles for Syria. ${ }^{195}$

News of the Mongol defeat reached Abaqa in Mosul (al-Mawsil), ${ }^{196}$ and disappointed him greatly. He decided to avenge his brother's defeat the next year. He set out for Hamadān and arrived there on 18 March 1282, where after a heavy drinking bout that later would be considered an assassination, he died on 1 April $1282 .{ }^{197}$ He was laid to rest alongside his father on the island of Shāhī. ${ }^{198}$

Abaqa's period can be justly identified as the high point of the Mongol-Armenian military relationship, where both parties played a keen role in assisting each other to take over Northern Syria, pursuing not similar, but common goals. After this, Mongol-Armenian relations were maintained through diplomacy, rather than through joint military actions.

\section{Mongol-Armenian Relations in the Time of Tegüder Ahmad (r. 1282-1284)}

After the death of Abaqa Khan, Western rulers learned that Mongol power in the Middle East was now held by one who was less favourable to the Christians. After Möngke-Temür died, the candidacy for the next Il-Khan was discussed widely among the descendants of Hülegü. Tegüder, Hülegü's son, the younger brother of Abaqa Khan,

${ }^{193}$ Het'um Patmich', 1951:58.

194 Ibid., 58-59; King Het'um II, 1962:75.

195 Step'annos Orbelian, 1910:423.

${ }^{196}$ From 660 H. (1272), Mosul became a finance and trade centre of the IlKhanate with the south-west (Kolbas, 2006:166).

197 An Armenian source attributes Abaqa's death to poison, given by the Mamluks when the Mongol Il-Khan was planning to fight against the Egyptians (Het'um Patmich', 1951:59).

198 Rashīd al-Dīn, 1954:779. 
and the governor of Kurdistān had more support and a more powerful position than Abaqa's eldest son Arghun. ${ }^{199}$ On 6 May 1282, Tegüder's proclamation took place at Ala-Tagh. According to Het'um Patmich', Tegüder 'in his childhood had been baptised and called Nicholas ( (hlinnuunu), but later, being acquainted with the Saracens whom he loved, he became a Saracen and wanted to be named as Mahomet Khan. He tried with much effort to convert the Tatars to the faith of Mahomet. ${ }^{200}$ As a convert to Islam, he was not only named Ahmad after the dervishes of the Ahmadiyya sect, but also given the title of Sultan. ${ }^{201}$ An alternative point of view can be ascertained from the sources not only in the details of his conversion, ${ }^{202}$ but also in his policy towards the Muslims and the Christians. According to Het'um Patmich', Tegüder (Ahmad) pursued an antiChristian policy, ordering the destruction of the Christian churches in Tabriz and forcing all Christians to adopt Islam. For this reason, the Armenians experienced terrible persecution. ${ }^{203}$ From this period onward, the cases of people during the Mongol period lamenting over their sins is augmented in the Armenian sources. In connection with this view, Lane states that the evidence of the Armenian chroniclers appears to be a sectarian interpretation by an isolated and threatened minority group of Christians (Armenians). ${ }^{204}$ This statement sounds reasonable for the Armenian anti-Christian portrayal of Tegüder; however, it is contradicted by Bar Hebraeus. The Syriac source depicts Tegüder as merciful to those of the Christian faith, as one who issued decrees to free all churches, religious houses and priests from the imposition of taxes in the lands under the Mongols. ${ }^{205}$ These opposing statements by the Christian sources may reflect not only the Armenian response to the Il-Khan's conversion, but also Tegüder's ambivalence in the matter of his faith, and can be contrasted with the opinion of Reuven Amitai, who emphasises that

199 Rashīd al-Dīn, 1954:785.

${ }^{200}$ Het'um Patmich', 1951:59. The Armenian historian may mean the rise of Shaikh Kamāl al-Dīn 'Abd al- Rahmān at Abaqa's court and his influence on the minor Tegüder and his mother, which is discussed by Amitai, 2001:21.

${ }^{201}$ Rashīd al-Dīn, 1954:785.

202 According to the Mamluk sources, Tegüder had become a Muslim first and then he ascended the throne, unlike the other Mongol converts (Amitai, 2001:1822).

${ }^{203}$ Het'um Patmich', 1951:59-60; Step'annos Orbelian, 1910:425.

204 Lane, 2003:56.

${ }^{205}$ Bar Hebraeus, 2003:467. 
Tegüder's early conversion 'had nothing to do with a mature person's crisis of faith. ${ }^{206}$ Probably at that time, neither Tegüder, nor the Mongol court in Iran completely realised the full responsibility and consequences of their actions. Tegüder was the first Mongol Muslim ruler in Iran and made his religion a public matter. ${ }^{207}$ His religious ambivalence is shown from research on the coinage during his reign. Tegüder minted a coin in Tiflis in 1282 with a Trinitarian Christian inscription in Arabic, In the name of the Father and the Son and the Spirit, Holy God is one. ${ }^{208}$

The Armenian work of Step'annos Episkopos asserts that after Tegüder (Ahmad) had changed his title of Khan to Sultan, senior positions at his court were given to the Persians. ${ }^{209}$ The office of șâhib-dìvān was a key position in the echelons of power in the Il-Khanid Empire. Șạhị-dīvān Shams al-Dīn Juvaynī, who served Abaqa and later his son Arghun, first transferred his service to Tegüder. Shams al-Dīn became a major source of conflict that had already existed between Arghun and Tegüder from the very first day of the latter's proclamation. The Juvayni brothers were accused of being in league with the Mamluks and Shams al-Dīn was blamed for the misuse in Abaqa's time of huge sums from the royal treasury. Later, he was charged with administering poison to Abaqa Il-Khan. ${ }^{210}$ Arghun believed this accusation. However, Tegüder not only restored Shams al-Dīn Juvaynī as șāhib-dìvān, but also followed his advice to open negotiations with the Sultan of Egypt. ${ }^{211}$

Interestingly, Tegüder's first message to the Sultan dated midJumada I 681 (22 August 1282), was far from being a call for an alliance; it was an ultimatum of the Mongol Il-Khan, who urged Qalāwūn to show submission in order to secure his sovereignty. ${ }^{212}$ In his reply to Tegüder, the Sultan expressed his readiness to make peace with conditions to be discussed later, ignoring the issue of submission. ${ }^{213}$ In his second message to Qalāwūn dated at the begin-

\footnotetext{
206 Amitai, 2001:22.

${ }^{207}$ Ibid., 15.

${ }^{208}$ Kolbas, 2006:238.

209 Step'annos Episkopos, 1951:45.

${ }^{210}$ Rashīd al-Dīn, 1954:786.

${ }^{211}$ Ibid., 788. Tegüder was the first among the Il-Khans to initiate negotiations with the Sultan to end the Mongol-Mamluk conflict (Amitai, 2005:360).

${ }^{212}$ Jackson, 2005a:169; Allouche, 1990:438. On the tone of Tegüder's letter to Qalāwūn as an equal, rather than as a subordinate, see Pfeiffer, 2006c:185-187.

213 Allouche, 1990:441.
} 
ning of Rabī' I 682 (May-June 1283), Tegüder omitted words of obedience and submission and spoke only about peace and an agreement between the Il-Khans and the Mamluks. ${ }^{214}$ When the envoys arrived in Damascus in February-March 1284, with the message from Tabriz, the news of the death of Tegüder (Ahmad) and the accession of his rival nephew Arghun reached Qalāwūn. ${ }^{215}$

Tegüder's policies with the Mamluks met serious opposition from the Mongol elite in Iran and Anatolia. ${ }^{216}$ Arghun began his open rebellion against Tegüder (Ahmad) in the Spring of 1283. If we believe Het'um Patmich', Arghun turned to Qubilai Khan to complain about Tegüder. Qubilai Khan warned Tegüder that he himself would come up against him if he did not pull back. ${ }^{217}$ According to this statement, and what is mentioned by Step'annos Orbelian and Sebastats' $i$, the Armenians supported Arghun. ${ }^{218}$ Tegüder employed his son-in-law, the Georgian General Alinaq (Alinakh) against Arghun. The Georgians might mistakenly have seen their chance to gain political authority through Tegüder. According to Kolbas, from 1282, the equal number of coins struck in Tiflis and in Tabriz shows the growing influence of the Gurjistan area in Tegüder's time. ${ }^{219}$ Alinaq arrested Prince Qongqurtai, the younger half-brother of Tegüder, a supporter of Arghun; moreover, he imprisoned Arghun in July $1284 .{ }^{220}$ According to Sebastats' $i$, Tegüder killed not only his brother Qongqurtai, but also many Mongol nobles, Georgian lords and the Seljuk Sultan Ghiyāth al-Dīn, the son of Rukn al-Dīn, in the same year 1284. ${ }^{221}$ The other Armenian sources describe Tegüder killing many others, including the two sons of Tsagan, the great governor of Georgia. ${ }^{222}$ To judge from these accounts, one can see that the Georgians' inclination towards Tegüder turned out to be detri-

214 Ibid., 443.

${ }^{215}$ Ibid. On Ahmmad Tegüder's second letter to Qalāwūn, see Pfeiffer, 2006c:167197.

216 Allouche, 1990:438-90; Pfeiffer, 2006c:185-188. In 1284, he executed his younger brother Qongqurtai, on a suspicion of conspiring against him in concert with Arghun (Amitai, 2001:15).

${ }^{217}$ Het'um Patmich', 1951:60.

218 Step'annos Orbelian, 1910:425; Sebastats'i in Hakobyan, 1956:148.

${ }^{219}$ Kolbas, 2006:236.

220 Step'annos Episkopos, 1951:46.

221 Sebastats'i in Hakobyan, 1956:148.

222 Step'annos Orbelian, 1910:425; Step'annos Episkopos, 1951:46. 
mental to them. As has been said above, Armenian interests lay with Arghun.

In addition to this, the amirs and princes of the House of Hülegü were displeased with Tegüder's actions. Amir Bugha, who was secretly in sympathy with Arghun, released the latter and killed Alinaq, as well as all of Tegüder's supporters. ${ }^{223}$ In return, Tegüder reached Qongqur-Öleng (Sultaniyya), Bugha's ordu and looted it. In his own ordu in Songhurluq at Shīz (Takht-i Sulaymān), he prepared to reach the Derbent gate and escape to the territory of the Golden Horde. However, he was arrested and brought to the Chinggisid family trial, being accused of the execution of Prince Qongqurtai. Tegüder's death sentence was carried out on 10 August $1284 .{ }^{24}$ With the elimination of Tegüder, the Mongol-Armenian alliance recovered itself with another strong partnership of rulers.

\section{The Second Pairing of Arghun and King Lewon III against Sultan Qalāwūn}

Arghun's reign was well regarded in both Cilician Armenia and Greater Armenia. According to Step'annos Orbelian, the Houses of Zak'arian, Artsruni and Orbelian along with the Georgian King Demetrē (r. 1270-1289) were fully in support of Arghun. ${ }^{225}$ He was enthroned on 11 August 1284, the day after his predecessor's execution, on the banks of the river Shür in the presence of the khatuns, amirs and some princes. ${ }^{226}$ It seems that, in order to maintain a firm hold over his domain, Arghun was engaged with executions and new

223 Rashīd al-Dīn, 1954:790-98.

224 Ibid., 798-800. Step'annos Episkopos states that Tegüder tried to escape by changing into female dress; however, he was caught, tortured and killed (Step'annos Episkopos, 1951:47). Tegüder was killed in the same way as he executed Qongqurtai, his half brother, through the breaking of his back, the location of his tomb is not known (Vașșaf, 1856:278[trans. 261]).

225 Step'annos Orbelian, 1910:426.

226 Rashīd al-Dīn, 1954:807. The official sanction for Arghun's accession to the Il-Khanid throne came later on 7 April 1286, from Qubilai Khan. For this reason, the second quriltai was summoned (Rashīd al-Dīn, 1954:812). Eliminating Tegüder, Arghun aimed to bring Anatolia directly under his control. He sent his brother Geikhatu and uncle Hulachu to Rūm as governors in 1284 (Sebastats'i in Hakobyan, 1956:148). His son Ghazan was sent to the provinces of Khurasan, Mazandaran, Qūmis and Ray along with Nawruz, whose duty was to support Ghazan as Amir of Khurasan, while his uncle Adjay was sent to Gurjistan vilayet (Rashīd al-Dīn, 1954:808). 
appointments. Arghun ordered the execution of Ebügen, the son of Shiramun, the grandson of Chormaghan, and Tegüder Ahmad's protégé. ${ }^{227}$ Then Shams al-Dīn, the deputy to vizier Bugha, was executed in October 1284. ${ }^{228}$ Bugha himself became a victim of the internal conspiracy within the Il-Khanid court and being betrayed by Jüshkeb, Arghun's cousin, was put to death on January 1289. ${ }^{229}$ His office was given to Sa'd al-Daula, a Jewish physician. But in March 1291, he also was executed. ${ }^{230}$

The death sentences continued in Georgia as well. The Georgian King Demetrē, the son of David Ulu, who reigned over the eastern part of Georgia, and actively participated in Abaqa's campaign against the Mamluks between 1277 and 1281, was a true vassal of the Il-Khans. He played a great part in subduing the rebels in Derbent (provoked by the Golden Horde) in 1288 on the order of Arghun Khan. However, Arghun discovered the plot allegedly organised by Bugha. ${ }^{231}$ According to Step'annos Orbelian, Arghun falsely suspected the involvement of Demetrē in this intrigue only because he was married to Bugha's daughter. ${ }^{232}$ Demetrē was killed on the plain called $U$ nıцlqui (Mughan) on the bank of the river Kur in 1289. ${ }^{233}$ The sources are open about the persecution of the Georgians but say nothing about the Armenians. A reason for this could be that the Armenian lords were personally closer to the Il-Khans, rather than to the Georgian crown. They also helped the Il-Khans find a proper candidate for the Georgian throne. Hence, with the assistance of Khutlu Bugha, the son of the Armenian Lord Sadun Artsruni, Arghun enthroned Vakhtang II (r. 1289-1292), the grandson of Rusudan, as

${ }^{227}$ Ibid. On 7 September 1296, the other son of Shiramun was executed (Rashìd al-Dīn, 1946:171).

${ }^{228}$ Rashìd al-Dīn, 1954:811.

${ }^{229}$ Ibid., 817-18; Aubin, 1995:40-44. In 1286, Bugha was honoured with the title of Chink'san[k] (from Chinese ch'eng hsiang [chancellor]) bestowed by the Great Khan (Rashīd al-Dīn, 1954:812; Allsen, 2001:28.

${ }^{230}$ Rashīd al-Dīn, 1954:825.

231 The Greater Armenian poet Frik in his poem About Arghun Khan and Bugha was very explicit in showing his sympathy towards Arghun. According to him, Arghun, the Chinggisid son was chosen by God, who cannot be beaten by anyone (Frik, 1941:209-215, 1952:422-223).

${ }^{232}$ King Demetrē II practised polygamy by marrying three wives; the second was a Mongol princess named Songur, a daughter of Bugha Chink'san[k]. He had three children by this Mongol wife, one of whom, a princess called Jigda, was given in marriage to Alexius III of Trebizond (1338-1390).

${ }^{233}$ Step'annos Orbelian, 1910:430. 
the Georgian king. The latter appointed Khutlu Bugha Artsruni as the uupuuulup (general) of the Georgian army. ${ }^{234}$ While the Georgians were mistreated, the Armenians in Greater Armenia profited. It was Tarsaich Orbelian who succeeded in eliminating from the royal tax registry about 150 Armenian monasteries and convents, which was confirmed again by Arghun's decree in $1287 . .^{235}$ In 1290, after the death of Tarsaich, Arghun solved the dispute among Tarsaich's sons over their father's succession and appointed Elikum Orbelian as atabeg of the Armenians. ${ }^{236}$

Placing Georgia and Armenia under his direct control, Arghun successfully defended his realm from the brief incursions of TöleBuqa (r. 1287-1291) in 1288 and of Toqta (r. 1291-1312) of the Golden Horde in $1290 .{ }^{237}$ But another danger to Arghun came from the rebellion of Nawruz, the son of Arghun Aqa, who was sent as the military governor to Khurasan along with Ghazan, the son of Arghun Il-Khan. ${ }^{238}$ According to Step'annos Episkopos, Ghazan fled from Nawruz, while Arghun sent a large force to suppress the rebels. ${ }^{239}$ The rebellion of Nawruz lasted for five years from 1289 to 1294 and kept Arghun busy concentrating on local matters. ${ }^{240}$ However, the Armenians did not lose the opportunity to remind him about their mutual affairs.

As has been mentioned earlier, the Armenian King Lewon III visited Arghun in 1285. He was well received by the Mongol Il-Khan. ${ }^{241}$ However, Mongol foreign policy turned out to be harmful to the Cilician Armenians. Arghun employed 800 Genoese in building ships at Baghdad as a result of his first appeal for joint Mongol-Latin operations. He aimed to take from the Egyptians their trade in the Red Sea. ${ }^{242}$ In revenge, Sultan Qalāwūn raided and pillaged the Cilician Armenians in 1285.

Arghun's relation with the Cilician Armenians brought much dissatisfaction. In 1285, Lewon was forced to sign a ten-year treaty with

\footnotetext{
234 Step'annos Episkopos, 1951:49. Persian sepahsālār (commander-in-chief).

235 Step'annos Orbelian, 1910:427, 429.

236 Ibid., 430-431.

237 Rashīd al-Dīn, 1954:821-822; Boyle, 1968:370.

238 Rashīd al-Dīn, 1954:819; Melville, 1995:56.

239 Step'annos Episkopos, 1951:50.

240 Boyle, 1968:370; Melville, 1995:56-57.

241 Sebastats'i in Hakobyan, 1956:148.

242 Jackson, 2005a :169.
} 
Cairo at the high cost of an annual tribute of one million dirhams. ${ }^{243}$ This agreement gave Cilicia relative peace and allowed Lewon to concentrate his attentions on improving the living conditions of his people. He started to rebuild Sis and its monasteries, to safeguard trade and pilgrimage routes, to increase commerce and market revenues in Ayas, which helped Lewon to meet the heavy tributes levied by the Mamluks. ${ }^{244}$

The reign of Lewon III was marked by a number of invasions into Cilician Armenia by the Mamluks and by Turkomans and Kurdish bandits. ${ }^{245}$ Lewon's hopes lay again in the Mongol alliance; however, little assistance came from it. The Mamluks, now under the Sultan Qalāwūn, having won the neutrality of the Franks, completely destroyed the allied forces. Lewon died in 1289 and was succeeded by his eldest son Het'um II (r. 1289-1293; 1295-1297; 1299-1305; joint ruling 1305-1307), who would experience more troubles caused by his having too many ambitious brothers. ${ }^{246}$

In order to resolve the Mamluk-Mongol war, Arghun continued his father's policy of seeking an alliance with the Franks. He sent four missions to the Latin West; some were undertaken jointly with the Armenian monarch. The first was in 1285, accompanied by Qubilai's envoy called 'Îsā Kelemechi, sent to Pope Honorius IV (1285-1287). ${ }^{247}$ In the letter, it was proposed to divide the land of Egypt between Arghun's dominions and the West. ${ }^{248}$ In 1287, the second embassy led by Rabban Șawma, a Nestorian prelate from

${ }^{243}$ Boase, 1978:28; Der Nersessian, 1973(I):349. The treaty was signed to last for ten years, ten months and ten days. In addition to the annual tribute, Cilicia was obliged to supply 25 pedigree horses, the same number of mules and 10,000 iron bars for horse-shoes along with nails (Mikaelean; 1952:414; Langlois, 1862:217-231, Canard, 1967:217-259). The text of this treaty given by 'Abd al-Zāhir in Tashrîf (93102) is translated into English (see Holt, 1995:95-103). A dirham was a silver coin, six dirhams were equal to one dinar or golden coin (Feodorov-Davydov, 2003:3033).

${ }^{244}$ Mikaelean, 1952:415. The financial condition of the clergy improved. Historiography flourished, as Lewon's secretary, Vahram, left a detailed account of Cilician history and contemporary events. For details, see Vahram, 1831.

${ }^{245}$ Turkomans provided constant internal disruption to the Mongols in Anatolia as well (Melville, 2009:51-101).

246 Stewart, 2001:65. Lewon was married to Queen (Ker) Ann, and they had seven sons and four daughters. Rüdt-Collenberg states that Lewon and Ann had 14 children (Rüdt-Collenberg, 1963:32). Het'um II was married to the daughter of Hugh III of Cyprus (r. 1267-1284) (Mikaelean, 1952:416).

247 Lupprian, 1981:245-246.

248 Jackson, 2005a:169. 
China set out for Europe. ${ }^{249}$ They returned the next year bringing letters from the newly-elected Pope Nicholas IV (1288-1292), Edward I of England and Philippe le Bel of France full of assurances of support but no promise of actual assistance. ${ }^{250}$ In 1289-1290, another mission was sent by Arghun to the Pope, and the Kings of England and France. In reference to these events, Step'annos Episkopos states that in the same year, the renowned emissaries of the Pope visited Arghun and built an expensive church at his Court, which was consecrated. ${ }^{251}$ Arghun initiated another mission, which carried letters to Rome from the next Armenian king Het'um II, proposing a Mongol-Rome-Armenian alliance against the Mamluks. ${ }^{252}$ The last emissaries arrived in the Summer of 1290 and brought to Arghun in 1291 the reply from Pope Nicholas IV, who, after learning that Acre, the last Frankish-held stronghold in Palestine, had fallen, urged the Il-Khan to be baptised and to move against the Mamluks. ${ }^{253}$ Arghun had already died by that time, and the Pope himself died in the following year, without managing to instigate the crusade. ${ }^{254}$

The Il-Khan Arghun's reign was another chance for the Armenians to implore the Mongols to free the Holy Land. Although Arghun accepted this idea, he could not fulfil his promise during his reign. His monetary reforms to increase the weight of coins, the regulations of their minting cycles, and the use of subsidiary coinage for the payment of foreign trade were dictated by the stability of the financial system in his realm. ${ }^{255}$ Arghun was interested more in science, alchemy, building and treatments for longevity. He tried many alternative medicaments on himself: Indian, Jewish and Muslim. ${ }^{256}$ Eight months of consuming a mercury-based elixir made him chronically

${ }^{249}$ This time Sawma was accompanied by ‘Saabedin' who later visited Europe as part of the embassies of 1290 and 1302 (Jackson, 2005a:173). This 'Saabedin' might be the same Sahmaddin, an Armenian merchant who owned vast lands rich in orchards to the south-west in Greater Armenia, near to caravan routes (Mikaelean, 1952:422; Khachikyan, 1958:104).

${ }^{250}$ Budge, 1928:165-197; Rossabi, 1988:152.

${ }^{251}$ Among those who consecrated the church, there were the Nestorian catholicos from Baghdad along with 12 Armenians, and the Episkope from Varag monastery (Step'annos Episkopos in Hakobyan, 1951:50).

${ }^{252}$ Bundy, 1987:227-228; Golubovich, 1906(1):301-306, 1906(2):440; K'evorkian, 1996:188-195; Mutafian, 1999.

${ }^{253}$ Lupprian, 1981:270-276.

254 Jackson, 2005a:169.

${ }^{255}$ For the monetary reforms of Arghun, see Kolbas, 2006:245-256.

${ }^{256}$ Rashīd al-Dīn, 1954:821, 823. 
ill. Learning that the Il-Khan's life was in danger, the amirs' mutual hostility was increased and they started to form a conspiracy to eliminate each other. Disorder and outrages took place in Tabriz and Baghdad. ${ }^{257}$ Arghun died on 10 March 1291 in Arran. ${ }^{258}$ His partnership with Lewon III did not bring any of the desired results. Instead, the Armenian kingdom became a tributary to the Mamluk Sultan. Although Sultan Qalāwūn was not as aggressive as Baybars, his constant raids on Cilicia served to put the Armenians under economic pressure.

\section{The Weakest Link: Het'um II and the Mongol Il-Khans: Geikhatu (r. 1291-1295) and Baidu (1295)}

After the deaths of Arghun Il-Khan and King Lewon, the Mamluk policy became more aggressive towards the Il-Khanate and Armenia. The reason for this was the succession of the very ambitious and energetic Mamluk Sultan al-Ashraf Șalāḥ al-Dīn Khalì (r. 689-693 H. / 1290-1293), the son of Qalāwūn, and of feeble candidates as rulers in the Il-Khanate and Cilician Armenia. Het'um's vacillations between the throne and the monastery allowed some scholars to conclude that he was 'little suited to the times. ${ }^{259}$ The Mongol noyans, amirs and their supporters, who summoned a quriltai held near Akhlāt on 23 July 1291 (24 Rajab 690), had a choice of three candidates for the next Il-Khan, and chose unwisely. As stated above, Arghun's son Ghazan was in Khurasan. His brother Geikhatu (Gaikhatu) was in Rūm and his cousin Baidu in Baghdad. ${ }^{260}$ The main focus was on the brothers of Arghun, rather than on his son. Geikhatu's supporters were stronger than Baidu's, so he was proclaimed as Il-Khan. ${ }^{261}$ Geikhatu was known more for his failure in an innovative monetary policy, rather than for his political activities. The introduction of Chinese paper money called chäo to replace the

257 Ibid., 825.

${ }^{258}$ Ibid., 825. According to Sebastats'i, Arghun Khan was poisoned along with his șāhib-dīvān Sa'd al-Daula (Sebastats'i in Hakobyan, 1956:149).

259 Boase, 1978:29.

260 The Buddhist name of Geikhatu or Gaikhaltu (which means 'remarkable' in Mongolian) was Irinjin Dorji or Rintsen Dorji (Rashīd al-Dīn, 1954:829); it was used on the silver coins minted in Tabriz in 693 H. (1294) (Kolbas, 2006:279).

261 Rashīd al-Dīn, 1954:830. 
metallic currency in Tabriz on 19 Shawwal 693 (12 September 1294), in order to overcome economical difficulties, proved a fiasco. ${ }^{262}$

Information about Geikhatu (ntquuhqu) is very obscure in Armenian sources. Some describe him as a man who had neither laws, nor faith. ${ }^{263}$ The debauchery of Geikhatu, which is found in Rashīd al-Dīn and in Vașșaf, is noted by Het'um Patmich' and by the continuator of Bar Hebraeus. ${ }^{264}$ Sebastats'i records only that Geikhatu (fujnuunn ) caused much destruction in a place called Tongozlu in 740 Arm. (1291). ${ }^{265}$ Arabic sources also do not have a high opinion of Gaikhatu. ${ }^{266}$

According to the Chronicles of King Het'um II, during the reign of Geikhatu there were many occasions when the Mamluk Sultān al-Ashraf Khalil (r. 1290-1293) had attacked the coastal castles of the crusaders, such as those at Acre, Tyre and Beirut, and the cities in the privileged trading area on the right bank of the Euphrates in 1291, forcing the Christians to flee. ${ }^{267}$ The Mamluks of Egypt decided to drive out the crusaders once and for all, and to eliminate the Franks from the region. ${ }^{268}$ Letters were exchanged between Geikhatu and al-Ashraf, when the war began to escalate again. ${ }^{269}$ In addition to this, three different letters were registered which were received by Edward I in 1291. The first one was from Het'um II on the fall of Acre to the Mamluks and on the Armenian appeal for aid to the crusades. ${ }^{270}$ The other two were the letters of Sultān al-Ashraf Khalil to Het'um forwarded to Edward. ${ }^{271}$ The content of these letters was probably about the Mamluk supremacy and threats to Cilician Armenia in connection with the fall of Acre and Tyre. ${ }^{272}$ In any case, these letters testify to the unpromising situation in Cilician Armenia.

In fact, the Mamluks' raids throughout Cilicia were directly linked with the weak position of King Het'um II, who repeatedly abdicated. The Armenian monarch often sought refuge in the church, first in

262 Ibid., 835.

263 Het'um Patmich', 1951:62.

264 Ibid., 62; Bar Hebraeus, 2003:494.

265 Sebastats'i in Hakobyan, 1956:149.

266 Abu'l-Fidā'; 1983:24; Stewart, 2001:68.

267 Galstyan, 1962:76; Hakobyan, 1956:79.

268 Mikaelean, 1952:416.

269 Al-Maqrīzī, 1934-1974(I):786; Amitai, 2005:361.

270 Lloyd, 1988:251.

271 Ibid., 251-252.

272 Ibid., 251-52; Stewart, 2001:67. 
the monastery he had built at Mamistra and later by becoming a friar called John in a Franciscan church. ${ }^{273}$ The Papacy was active in sending Franciscan missions to Cilicia. ${ }^{274}$ Het'um II entered into diplomatic contacts with the Papacy. Het'um sent an embassy of four people to the Pope on the matter of the Holy Land in 1292. Nicholas IV sent them on with letters of commendation to Edward I of England. There was also a letter sent by Nicholas IV to 'all the faithful' about oppression in regions of Cilician Armenia in 1292. ${ }^{275}$ However, just as Byzantine rulers had tried to force Greek Orthodoxy on the Armenians, the Papacy, in return for their help, required the Armenians to accept Catholicism. ${ }^{276}$ Some nobles and ecclesiastics in Cilicia converted to Catholicism, which led to a rift between the episcopacy in the Cilician Kingdom and in Greater Armenia. ${ }^{277}$

In order to end pro-Latin and anti-Latin conflicts within his realm and to deal with the Mamluks himself, Het'um II tried to appease the Egyptians by offering large sums of money. In 1292, Sultan alAshraf seized Hromklay (Qal'at al-Rūm in Arabic), the See of the Armenian Catholicos, which was a very strongly fortified place on the bank of the Euphrates. ${ }^{278}$ According to an Arabic source, the Cilician monarch tried to relieve the defenders of Hŕomklay. He dispatched a cavalry force of 5,000 men, dressed as Mongols, to halt the Mamluks. ${ }^{279}$ The Armenians wore Mongol hats (sarāqūjāt), imitating the Mongols, to attack the caravans. ${ }^{280}$ When al-Ashraf found that it was a false Mongol raid, he sacked the citadel. The Armenian chronicler of the fourteenth century Nersēs Palients' details the siege of Hŕomklay:

In the Armenian year 741 (1292), the Egyptian Sultan Ashraf after he had captured and destroyed Ak'a [Acre] nearly wiped out all Christian lords and even their names from the Holy Land and from the coastal area. Afterwards this evil dragon embarked upon the Armenians, and moved with the army to Mesopotamia closer to the border of the city of Uŕha [Edessa]. He surrounded the fortress of the Armenian Patriarch that was called the Castle of Hromklay, where the see of the Arme-

\footnotetext{
${ }^{273}$ Crawford, 2003:137.

${ }^{274}$ Der Nersessian, 1969:50.

${ }^{275}$ Lloyd, 1988:255, 259.

276 Mikaelean, 1952:417.

277 Der Nersessian, 1969:50.

278 Abu'l-Fidā'; 1983:18-19.

279 Stewart, 2001:78.

280 Amitai-Preiss, 2004:132.
} 
nian Patriarch existed for a long time. The Sultan besieged it [severely] with constant force so that the Christians could not defend it, because the Armenian King sent his maternal uncle there, the Baron Raymond ( $R$ tunnin) along with numerous elite men. The Tajiks did not manage to take the fortress despite fighting for many months.

... The Armenian Catholicos, Ter-Step'annos, surnamed Hŕomaets'i, who was inside the fortress, finding no means [to survive] put on his patriarchal robe, the same as the other bishops, and with the crosses and with holy relics they went to the feet of the Sultan. People say that when the tyrant saw this, he spat on the Catholicos, saying: 'Why did you not do this on the first day?' Since they themselves came to him, the order was given to kill no-one. In this manner, the same Sultan took Hromklay on the same day. The Catholicos along with all the Christians, more than 30,000 people, were taken into captivity to Egypt as prisoners and as slaves. ${ }^{281}$

Het'um II freed the Catholicos for a ransom, giving the impregnable fortress of Behest (Behesni) to the Egyptian Sultan. ${ }^{282}$ In 1293, the next Armenian Catholicos Ter-Grigor VII (1293-1307) moved the see from Hromklay to Sis. ${ }^{283}$

Mamluk policy towards Cilician Armenia turned out to be more threatening because al-Ashraf aimed to conquer even more than Baybars had. ${ }^{284}$ In the same year, the Mamluk army, stationed at Damascus, received orders to march on Sis but famine and plague, which spread through Egypt and Syria in the same year, halted them. ${ }^{285}$ After the fall of Hromklay, the Il-Khan Geikhatu wrote to the Sultan about his intention to sack Aleppo. ${ }^{286}$ However, Geikhatu was threatened by the letters of Sultan al-Ashraf who said he would invade Baghdad, ${ }^{287}$ so no help could be given by the Il-Khan to the Armenians. In contrast to the strong cooperation between Het'um I and the Mongol Il-Khans Abaqa and Arghun, the weak position of King

\footnotetext{
${ }^{281}$ Nersēs Palients', 1956:181.

${ }^{282}$ Hakobyan, 1956:80; Galstyan, 1962:76. Step'annos Orbelian, the contemporary historian, describes this event differently. He says that the Catholicos TerStep'annos was kept for about a year in prison in Egypt and died there. After his death, King Het'um tried his utmost but he lost the fortress of Behest to the Sultan (Step'annos Orbelian, 1910:444-445). However, both sources are in agreement that the Armenian King lost his fortress to the Sultan.

${ }^{283}$ Galstyan, 1962:129.

284 Stewart, 2001:85.

${ }^{285}$ Der Nersessian, 1973:349.

${ }^{286}$ Mikaelean, 1952:427; Amitai, 2005:361.

${ }^{287}$ Rashīd al-Dīn, 1946:135; Mikaelean, 1952:427; Boyle, 1968:373.
} 
Het'um II clearly coincided with the weak reign of Geikhatu Il-Khan, and this was certainly noticed by their enemies.

When al-Ashraf was murdered in December 1293, the Armenians were given breathing space. ${ }^{288}$ However, there were no Franks left in Syria and the Il-Khan Geikhatu was ineffective. In addition to this, in 1290, Genoa had already signed a trading agreement with Egypt to use Alexandria for its spice-trade with India, and King Alfonso III of Aragon (r. 1285-1291) and his brother, King James II of Sicily (r. 1285-1295) had signed a treaty with Cairo. ${ }^{289}$ Het'um II was left alone to act and he decided to strengthen his ties with Cyprus, the only other Christian kingdom surviving in the Levant. During his second reign, in 1295, Het'um II married his sister Zabel to Prince Amaury Lusignan (murdered in 1310), titular Lord of Tyre, and a brother of King Henry II (r. 1285-1324), whose children would later inherit the Cilician throne. ${ }^{290}$

Instability in the Mamluk Sultanate after the death of al-Ashraf gave respite to the Il-Khan as well. ${ }^{291}$ The only success to speak of with regard to the reign of Geikhatu was that he managed to achieve peace with the Golden Horde, receiving with honour the embassy of Toqta Khan (r. 1291-1312) in 1294..$^{292}$ This peace lasted until the reign of Abū Sa'īd (r. 1316-1335). ${ }^{293}$ Geikhatu and his successor Baidu (1295), whose reign lasted a very short time, left no record of having sent embassies to the West. ${ }^{294}$

Very little is known about the next Il-Khan Baidu, the son of Taragai and grandson of Hülegü, who contested the throne after Geikhatu. ${ }^{295}$ Rashīd al-Dīn mentions Baidu only briefly in connection with Ghazan's affairs. Qāọi Baị̂āwī (d. c. 716 H. / 1316) provided a short but important fact about Baidu, saying that after he had ascended the throne, he met Ghazan who came to him. Their talk

${ }^{288}$ Mikaelean, 1952:427; Stewart, 2001:93.

${ }^{289}$ Mikaelean, 1952:425.

290 King Het'um II, 1962:77.

291 The succession crisis of the 1290s: Baydarā al-Qāhir and al-Nāṣir Muhammad (1293), Kitbugha al-'Ābdil (1294), Lachin al-Manșūrī (1296), second reign of al-Nāṣir Muhammad (1298-1308) (Stewart, 2001:93).

${ }^{292}$ Geikhatu's failure in Il-Khanid affairs was caused by his preference for remaining in Anatolia, where he assisted Mongol tax officials to restore revenues in Konya (Melville, 2009:51-101).

${ }^{293}$ Rashīd al-Dīn, 1954:834; Boyle, 1968:374.

294 Jackson, 2005a:170.

295 Rashīd al-Dīn, 1946:19. 
resulted in a clash of armies on both sides. In Siyāhkūh, those who were in the service of Baidu inclined towards Ghazan. Baidu fled but he was caught, brought back and killed in Tabriz. ${ }^{296}$ The discord between Ghazan and Baidu, and the large army possessed by Baidu, are mentioned by al-Jazarī (d. 739 H. / 1339). ${ }^{297}$ The Armenian account in Sebastats'i refers to his short reign saying that it lasted six months, from April until October 1295. ${ }^{298}$ It seems that faith issues also beset Baidu. Step'annos Orbelian believes that Baidu was brought up as a Christian by Maria Despina Palaeologina, Abaqa's wife, along with her children. ${ }^{299}$ It is not clear when Baidu started to adhere to Islam but, according to Bar Hebraeus, the Il-Khan wavered between two faiths, Christian and Muslim; however, his conversion to Islam was symbolic, as he never fasted or prayed. ${ }^{300}$ Baidu was killed by Ghazan, who claimed to be the only legitimate heir to the throne. ${ }^{301}$

The instability of Het'um II, who, according to the chronicler of Cyprus 'had never wanted to be crowned while he was king, but rather wore the habit of the Franciscans and called himself Brother John of Armenia,' regrettably corresponded with the ineffective rules of Geikhatu and Baidu Il-Khans. Not being able to halt the most ambitions plans of the Mamluk Sultan al-Ashraf Khalil, the MongolArmenian partnership declined during their reigns.

Thus, the establishment of the Il-Khanate was a milestone in the Mongol, Muslim and Christian worlds. Within the Mongol Empire, disputes over the Il-Khanid territories led the Il-Khanate, the Golden Horde and the Chaghataid Ulus into a series of conflicts, causing Greater Armenia to suffer under Chinggisid warfare.

The implementation of the Mongols' conquest of the Syrian coast to fulfil their imperial ideology was supported by the Armenians, whose interest was based not only on the idea of the liberation of the Holy Land, but also on their need to safeguard their lands. Mamluk interest in controlling the Syrian coast was far more than for purely geographical or religious reasons: There was great economic concern

${ }^{296}$ Melville, 2007:54-55, 62.

297 Melville, 1990a:162-63.

298 Sebastats'i in Hakobyan, 1956:150. Baiḍāwī says that Baidu’s reign lasted seven months (Melville, 2007:62).

299 Step'annos Orbelian, 1910:470.

300 Bar Hebraeus, 2003:505.

${ }^{301}$ Manandian, 1952:305; Spuler, 1989:887-888. 
to control the resources and trade routes of the region. With the end of the Crusader epoch, the threat from Europe became meaningless, enabling Mamluks to reinforce their Egyptian power-base against the Mongols. Another party who tried to secure a place in MongolMamluk affairs was the Byzantine Emperor Michael VIII Palaeologus, who acted with political insight, courting the Mongols of the Golden Horde and the Il-Khanate and facilitating the successful operation of a trading zone by the Mamluks and the Golden Horde.

From 1265 to 1295, Mongol-Armenian collaboration against the Mamluks was exemplified by major pairings. Among these, the joint ventures of Abaqa and Het'um I were the most organised and victorious in achieving their goals. The partnership of Abaqa and Lewon III was the most productive in appealing to the Latin West. The duo of Arghun and Lewon III as allies was strong enough, although this collaboration had the most shameful result as it allowed the Armenian Kingdom to sign a ten-year tributary agreement with the Mamluk Sultanate. It is also worth noting that strong Mongol Il-Khans coincided with powerful colleagues in the Armenian Kingdom, for instance Abaqa and Het' um I, and Arghun and Lewon III. The reigns of weak Il-Khans coincided with those of weak Armenian kings.

Serious Mamluk political and economic challenges ensured the Cilician Armenians to stay close to their allies, the Il-Khans. However, the nature of the Il-Khanid relations with the Cilicia altered. This was followed by the series of appeals, both by the Armenians and the Il-Khans, to the Papacy. Their correspondence with the Latin powers, including the Kings of France and England, remains an excellent illustration of medieval diplomacy. These events established an exclusive multi-functional relationship, forcing the Mongols, Armenians, Mamluks and the Christian West into various collaborative efforts.

The Cilician Armenians were enthusiastic in appealing directly to the Il-Khans to liberate the Syrian coast from the Muslims. The Cilician Armenian interest in this venture was obvious. The question of the liberation of the Holy Land by the Mongols is still intriguing. The Latin hesitation in assisting the Mongols was also understandable. However, Mongol raids into Syria allowed the Armenian kingdom of Cilicia to reclaim lands lost to the Mamluks, although these repossessions had a temporary character. Through this collaboration with the Mongols, the Cilician Armenians became a direct target of the Mamluk Sultans. 
Conditions in Greater Armenia in particular, and the Caucasus in general, deteriorated with the intensification of hostilities between the Il-Khanate and the other Chinggisid Uluses. Provisioning and accommodating one or another party of Mongol Khans became a laborious game to play for the people of the region. However, Greater Armenia's interests lay more on the Il-Khanid side than on that of the other Chinggisids. 



\section{THE END OF MONGOL-ARMENIAN RELATIONS}

(1295-1335)

With the death of Abaqa Khan, Tegüder, as a convert to Islam, transferred the Il-Khanate to the Sultanate. ${ }^{1}$ The Mongol minority was absorbed slowly but steadily by the indigenous Islamic majority. The process of the Mongols' conversion to Islam reached its peak during the reign of Ghazan Khan when he adopted Islam. Ghazan, as a Mongol Chinggisid, actually demonstrated that affairs of state could prevail over the ancestral tradition of religious tolerance. The accomplishment of the Mongols' conversion to Islam was well received by the Muslims and is well documented in Muslim historiography. However, the reaction of the Christians, particularly Armenians, to this act is less known. In fact, the Armenians perceived the Mongols' conversion process in light of their national interest. Therefore, the arguments related to Mongol-Armenian relations after the Islamisation of the Mongol Il-Khans, the end of Mongol-Mamluk war during the reign of Öljeitü Il-Khan (r. 1304-1316), and the aftermath of the cooperation merits our attention.

\section{The Last Chance to Save the Alliance: Het'um II and the Il-Khan Ghazan (r. 1295-1304)}

As was noted earlier, the personality or individuality of each ruler in the Il-Khanate and Cilician Armenia was crucial in determining the direction of the relationship between the Mongols and Armenians. Our next pair of rulers, despite the fact that Ghazan was Muslim and

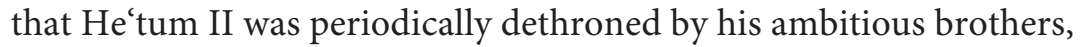
tried to maintain their relations.

When Ghazan Khan ascended as Il-Khan after five years of fighting for the throne, ${ }^{2}$ the Armenian chronicler states:

\footnotetext{
${ }^{1}$ Rashīd al-Dīn, 1954:785.

2 The name Ghazan derives from Qaisan, a cooking pot. The Mongol custom of naming a new-born child after the first person to enter the house applied to the Il-
} 
In 744 (1295) Ghazan killed Baidu and mounted the throne. Then he ordered Nawruz and Șadr al-Din [Zanjānī], the Sahib Divan to destroy all Christian churches and to put the priests to the sword. ${ }^{3}$

From this account, one expects to see both an obvious deterioration in the prospects for Mongol-Armenian affairs and negativity in the accounts of the chroniclers. Indeed, in October 1295, an order was issued to destroy all Buddhist monasteries, Christian churches and Jewish synagogues in Tabriz, Baghdad and in other cities of the Il-Khanate. ${ }^{4}$ But surprisingly, another statement follows:

However, the Armenian King Het'um happened to be there and with divine help, he succeeded in extinguishing the heart of Ghazan and in dissipating the anger towards the Christians. ${ }^{5}$

Het'um II and his brother Smbat I travelled to Iran in 1295 to see the Il-Khan Baidu in order to re-affirm their alliance with the Mongols. However, Ghazan was already on the throne. ${ }^{6}$ Knowing that the character of Mongol rule in the Il-Khanate could change with the Islamisation of the Mongols, the King was very keen to be assured that the Mongol-Armenian partnership was still operational. Ghazan Khan reassured King Het'um II that the Christian churches would not be destroyed and possibly promised military assistance. ${ }^{7}$

According to Armenian sources, Ghazan Khan was not entirely antagonistic to the Christians in Cilicia and the Caucasus. From the colophons of the Armenian Gospels from Vaspurakan and Nakhichevan both dated 1304, it appears that Ghazan Khan was a beloved, wise and beneficent monarch. He was a just king because, during his reign, there was 'peace on earth as in God's paradise.'8 This statement can be explained. The Il-Khan sought to wage war against the Sultan of Egypt with the help of Christian powers. There are records of the Il-Khan of sending embassies to King Henry II of Jerusalem and Cyprus (d. 1324) and to Pope Boniface VIII (1294-

\footnotetext{
Khan, when a slave girl entered carrying a cooking pot (Ibn Battutah, 2003:77). Ghazan was brought up by his grandfather Abaqa Khan until he was 10 years old and was taught by a Buddhist bakhshi (Rashīd al-Dīn, 1954:846).

${ }^{3}$ Sebastats'i in Hakobyan, 1956:150.

${ }^{4}$ Rashīd al-Dīn, 1954:908.

${ }^{5}$ Sebastats'i in Hakobyan, 1956:150; Anonymous in Galstyan, 1962:78.

${ }^{6}$ King Het'um II, 1962:77.

7 Step'annos Orbelian, 1910:474.

8 Sanjian, 1969:48.
} 
1303) in 1299. ${ }^{9}$ The Pope addressed the French King Philip IV (r. 1285-1314) and the King of England Edward I (r. 1272-1307), emphasising the importance of Cilicia in regaining the Holy Land after the fall of the Frankish states in the Middle East. ${ }^{10}$ However, the outbreak of hostilities between France and England in 1294, and the impending conflict of the Papacy with the French monarch put paid to this correspondence.

Before launching into a discussion of the military collaboration between Ghazan and Het'um II in Syria, it is important to introduce some aspects of the internal affairs of the Il-Khanate and Cilician Armenia.

From the beginning of his reign, Ghazan understood that, after the execution of his predecessor, the Mongol noyans might cause trouble and disorder in Iran. Consequently, he eliminated all candidates among the bloodline princes capable of resisting him. All the executions were implemented during the first 12 months of Ghazan's reign. ${ }^{11}$ Ghazan involved the amirs Qutlughshāh and Nawruz in suppressing the revolts. ${ }^{12}$ In order to keep power in his hands, Ghazan converted from Buddhism to Sunni Islam in September 1295. This should be considered a momentous event for Muslims in Iran and in the region..$^{13}$ As a Muslim ruler, he assumed the title of Sultan and the name Mahmūd. ${ }^{14}$ The conversion of Ghazan is attributed to the charisma of the Muslim mystics, or Sufīs, as well as the dervishes, known as qalandaris. ${ }^{15}$ This in turn brought about a mass conversion of Mongols, ${ }^{16}$ though in some cases only nominally. In fact, Mongol conversion to Islam was not a recent development; it already had its roots in Central Asia, where the Mongols were in constant contact with the Turkic-speaking Muslims. ${ }^{17}$ With Mongol penetration of the Middle East, these contacts intensified and accelerated steadily

${ }^{9}$ Jackson, 2005a:171.

${ }_{10}$ Mikaelean, 1952:429.

${ }^{11}$ Rashīd al-Dīn, 1954:912-917; Boyle 1968:381.

${ }_{12}$ Ibid., 1968:381-382.

13 Rashīd al-Dīn, 1954:902-903. For the various accounts of Ghazan's conversion, see Melville, 1990a:159-177.

${ }^{14}$ Boyle, 1968:381.

15 Dervishes were powerful mainly in the tribal society of north-west Iran and eastern Anatolia (Melville, 2003a:57-58).

${ }^{16}$ Rashīd al-Dīn, 1954:904; Melville, 1990a:166.

17 Barthold, 1977:463-494; 
in the new political situation. ${ }^{18}$ I agree that there are doubts about the sincerity of Ghazan's adoption of Islam and his actual understanding of his new faith. ${ }^{19}$ Indeed, the coins struck by Ghazan Khan in 1297 in Baghdad after his conversion to Islam, inscribed in Mongolian as 'The coinage of Ghazan Mahmud by the power of Heaven' correspond to the official invocations of the Mongol protocol 'Möngke Tengri-yin Xučun Dor' (by the Might of Everlasting Heaven). ${ }^{20}$ This was not surely an appeal to a shamanistic deity, but rather a claim of the Il-Khan to be the direct offspring of the Chinggisid. Nonetheless, regardless of his symbolic or token conversion, Ghazan is referred to as the Pādshāh-i Islām in contemporary Muslim historiography.

Scholars once questioned why the Mongols converted to Islam but not to Christianity. According to Leo de Hartog, Christianity was of much less importance in the Golden Horde than shamanism. Christianity was significant for the Mongols only at the beginning of their world conquest. ${ }^{21}$ Fletcher's statement, though without any solid evidence, on the origin of Islam as a religion of nomads and thus attracting the nomadic Mongols, is very contentious. He attributed the same quality to Tibetan Buddhism, particularly its dGelugspa creed, which was adopted by the Mongols after it became, as Fletcher argues, the Tibetan nomads' tradition. ${ }^{22}$ Moreover, his account of the parallels between the Mongol shamanistic concept of the universal deity Tenggeri (Eternal Sky) and the Semitic concept of Alläh, needs to be proved. My argument for the Mongols' conversion to Islam centres on the cultural assimilation of the outnumbered Mongols by the majority of Muslim subjects in order to retain the right to rule.

Ghazan needed to use political propaganda to appeal to the local subjects. The revival of Islamic institutions (madrasas and mosques), religious law (shari'a), and pilgrimage (hajj) consoled the religious scholars or 'ulamä'. ${ }^{23}$ This appeal was not only to the Iranian faith, but also to Iranian identity. The Mongols sought to be identified as the latest Iranian dynasty with Persian epic heroes from the Shähnāma

\footnotetext{
18 Bundy, 1996:34.

19 Melville, 1990a:171; Amitai, 1996:1-10.

20 Kolbas, 2006:323-324.

21 De Hartog, 1996:53-54.

22 Fletcher, 1986:44.

23 Melville, 2003a:57.
} 
(Book of Kings) written by Firdausi (ca. 935-ca. 1020). The Iranians idealised Ghazan as a Persian philosopher-king. ${ }^{24}$ In his turn, Ghazan appointed Iranians to the higher positions in his administration. ${ }^{25}$ Also religious figures, such as Shaikh Șafī al-Dīn (d. 1334), the ancestor of the Șafavid dynasty in Iran from 1501 until 1722 and who frequented all three of the last Il-Khans, was patronised by Ghazan. ${ }^{26}$

The person who assisted in enthroning Ghazan Khan and thus exercised power was chief amir Nawruz (Naurūz), a son of Arghun Aqa from the Oirat tribe. ${ }^{27}$ Nawruz was known in Greater Armenia and in the region for his hostility towards the Christians. ${ }^{28}$ It was he who issued instructions that the Christians and Jews had to wear distinctive dress, such as a girdle around the loins for the Christians and a mark on their heads for the Jews. ${ }^{29}$ His policy of pursuing the Caucasian Christians and his destruction of the churches in Baghdad, Mosul, Hama, Tabriz, Maragha, Nakhichevan, Siwnik', Somkhit, Kartli and a few other places in Georgia provoked riots and rebellion against the Mongols among the Georgian nobles in the $1290 \mathrm{~s} .{ }^{30}$ Thus in Nakhichevan, the Mongol governors were under threat from sudden raids by Georgio-Armenian forces who were displeased with the religious enmity of Nawruz. ${ }^{31}$ Later, Ghazan Khan expelled Nawruz to Khurasan and sent amir Qutlughshāh to restore peace with the Armenians and the Georgian King David VIII (r. 1293-1311), the cousin of Vakhtang II (r. 1289-1292). ${ }^{32}$ When Nawruz plotted against Ghazan, however, according to the Armenian source, his plot was revealed, with the help of the Armenian princes Liparit Orbelian and Eachi Proshian, and Nawruz and all his family were executed. ${ }^{33}$

\footnotetext{
${ }^{24}$ Melville, 2003a:54-55.

${ }^{25}$ Rashīd al-Dīn, 1954:853. However, there were still many Mongols in his bureaucracy (see Melville, 2006b:135-163).

${ }^{26}$ Melville, 2003a:58.

27 Aubin, 1995:61-68.

${ }^{28}$ Step'annos Orbelian, 1910:471-473.

${ }^{29}$ Bar Hebraeus, 2003:507.

${ }^{30}$ Step'annos Orbelian, 1910:472-473; Babayan, 1969:167.

${ }^{31}$ Ibid., 473.

32 Ibid., 475-476. King David VIII was appointed by the Il-Khan Geikhatu in 1293 and ruled over the eastern part of Georgia. In 1295, he supported Baidu. When Baidu was killed by Ghazan, the latter summoned David to Tabriz. David refused and Ghazan sent an expedition to ravage Kartli. In 1299, Ghazan appointed David's younger brother Giorgi V as king of Georgia.

${ }^{33}$ Step'annos Orbelian, 1910:475.
} 
According to Rashīd al-Dīn, Nawruz was captured in Herat by Qutlughshāh with the help of the governor of the city, Fakhr al-Dīn. ${ }^{34}$

Meanwhile, in Cilicia, King Het'um II was in danger. In 1296, he went to Constantinople, accompanied by T'oros, his brother and partner in the administration, to ask for the assistance of Byzantium in addition to that of the Mongols. Regardless of his pro-Latin policies, Het'um II sought alliance with the Byzantines. ${ }^{35}$ In his absence, his brother Smbat I (r. 1297-1299) seized power and went with presents to Ghazan Khan to be acknowledged and to marry a Mongol princess, the Il-Khan's relative. ${ }^{36}$ On his way back, he met his brothers near Caesarea. Subsequently, the usurper imprisoned Het'um II and T'oros. T'oros was strangled and Het'um was partially blinded. In 1298/1299, another brother of Het'um II, Constantine I (1298/1299) overthrew Smbat, and, having declared himself king, released Het'um. In 1299, Het'um retook the throne and exiled both Smbat and Constantine to Constantinople, where they died. ${ }^{37}$

Knowing that there was conflict over the Cilician throne among the Het'umid brothers, the Mamluk Sultan Lachin al-Manșūr (r. 1296-1299) intensified his raids in Cilicia. According to Het'um Patmich', the Mamluks attacked Cilician Armenia seeing the internal instability within the kingdom. ${ }^{38}$ The Arabic sources indicate a different reason for the attack, stressing the discord among the Mongols in the Golden Horde and the Il-Khanate, especially after the execution of Nawruz and his followers, which brought the Mamluks to Cilicia. ${ }^{39}$ The Mamluk invasion of bilād al-Sìs led by Badr al-Dīn Bektash al-Fakhrī Amīr-Silāh took place in May 1298. The Mamluk army entered Cilicia through the Syrian Gates. A detachment was sent to attack Ayas, the heart of the kingdom, but the Armenians withstood it. ${ }^{40}$ In connection with this, in 1298, the Armenian monarch (Smbat I) sent a letter to Pope Boniface VIII (1294-1303)

\footnotetext{
${ }^{34}$ Rashīd al-Dīn, 1954:932. For Muslim accounts of Naurūz, see Melville, 1990a:166-167, 170.

${ }^{35}$ Het'um married one of his sisters (Rita) to Michael Paleologos, later Emperor Michael IX in 1296. Another sister was engaged to a Byzantine prince, but died before her marriage (Rüdt-Collenberg, Table III, 71, n.157; Stewart, 2001:99).

${ }^{36}$ Mikaelean, 1952:428.

${ }^{37}$ Het'um Patmich', 1951:71; Nersēs Palients', 1956:182-183; Anonymous in Galstyan, 1962:79-80.

${ }^{38}$ Het'um Patmich', 1951:64.

39 Based on al-Maqrizī, Stewart, 2001:106-107.

${ }^{40}$ Stewart, 2001:114.
} 
through an embassy of two Dominican monks asking for help to resist the Mamluks. Without making any actual promises, Boniface provided the embassy with a letter of commendation to Edward I of England..$^{41}$ Meanwhile, the Mamluks headed north and besieged the castle of Hamus (H'amūṣ) in June 1298. Abu'l-Fidā' mentions that in Hamus, a great number of Armenians who had gathered there seeking refuge were taken into captivity. ${ }^{42}$ The Mamluks took T'il (Tall) Hamdun which had already been abandoned by the Armenians. ${ }^{43}$ The continuator of Anets'i states that by 1299, the Mamluks had seized half of Cilicia. ${ }^{44}$ The Cypriot source records that the Kingdom of Armenia was very weak and the Mamluks 'ruled' over almost all of Cilician Armenia. ${ }^{45}$

Intervention by the Il-Khan Ghazan in 1299 and 1300 allowed the Armenians to recover their lost territories. ${ }^{46}$ From this account, one can see that the Mongols came to help the Armenian Kingdom against Mamluk aggression once again.

When Ghazan raided Syria, the Il-Khanid army defeated the Mamluk Sultan al-Nāṣir Muhammad, Qalāwūn's 14-year-old son, near Hims [Emesa]. ${ }^{47}$ As a result of this expedition, the Mongols took Damascus on 31 December 1299. In connection with this, another interesting statement, the plausibility of which is questionable, is found in Nersēs Palients', the fourteenth-century author. He records that King Het'um, who joined Ghazan's troops with his force of 150,000 men, begged him to burn the city of Damascus, to which Ghazan answered: 'It would be a great sin to set this beauty on fire. I will give this city to my son and keep it for him. ${ }^{38}$ The chronicler continues that, when the young Sultan fled, King Het'um, with 4,000 Cilician Armenian elite horsemen, chased him as far as a place called Toli. According to Palients', as the Armenian King was unsuccessful

\footnotetext{
${ }^{41}$ Lloyd, 1988:255.

${ }^{42}$ Abu'al-Fidā', 1983:28.

43 Ibid., 29.

${ }^{44}$ Anonymous in Galstyan, 1962:84.

${ }^{45}$ Crawford, 2003:145-146.

${ }^{46}$ Het'um Patmich', 1951:64. A decisive Mongol victory at Wādī al-Khaznadār near Homș in 1299 was the only Mongol success in a major battle against the Mamluks (Amitai, 2005:361).

${ }^{47}$ Nersēs Palients', 1956:183; Jackson, 2005a:170.

${ }^{48}$ Nersēs Palients', 1956:183. The number of Armenian soldiers who took part in this battle varied from 10,000 to 50,000 and even 150,000 (Galstyan, 1962:95-96). Het'um Patmich' says that Ghazan wanted to keep Damascus for the needs of his court (Het'um Patmich', 1951:66).
} 
in catching the Sultan, he returned to Jerusalem and stayed there visiting the holy sites when Ghazan allegedly issued a decree to give Jerusalem to him. ${ }^{49}$ Afterwards, the Armenian King went to Ghazan in Damascus, where they spent a Winter together before both returned to their domains. ${ }^{50}$

The occupation of Damascus and the nearby region of al-Ṣalihịyya by the Armenian King during the Mongol raids is also commented on in the Arabic sources. ${ }^{51}$ This time, they explain that King Het'um gave his men a considerable sum to destroy the city in revenge for the ravaging of his land. ${ }^{52}$ Al-Yūninnī and Ibn Taymiyya, the Damascene writers, give details of King Het'um's appearance during his occupation of Damascus, saying that he looked pale, having grown a thick beard. ${ }^{53}$ As has been said earlier, since Hülegü's time the blame for plundering Damascus has been laid on the Mongols and especially the Armenians. Since Ghazan and the Mongols were already officially Muslims, on this occasion the blame was laid solely on the Armenians. ${ }^{54}$

Nevertheless, the Mamluks retook Damascus soon after. According to an Armenian source, amir Qibjaq, the governor of Damascus appointed by Ghazan, betrayed the Il-Khan and returned the city to Sultan al-Nāșir Muhammad (693-741/1293-1340 with breaks). ${ }^{55}$ The Armenian King Het'um was determined to retake Damascus, so, according to Nersēs Palients', the Cilician monarch visited Ghazan Khan and persuaded him to prepare for another raid on Syria immediately. ${ }^{56}$ In 1300, when Qutlughshāh again arrived in Damascus with a royal army and took it, Het'um joined him. Nersēs Palients' continues that instead of waging war against the Mamluks, the Mongols retreated having been bribed by nine carts of Mamluk gold. The Armenians followed them as far as the plain near Damascus where

\footnotetext{
49 According to an anonymous Georgian chronicler, in the aftermath of Ghazan's raid on Syria, Jerusalem was plundered by the Mongols and many Christians and Muslims were massacred (Amitai, 1987:246-247).

${ }^{50}$ Nersēs Palients', 1956:185-186.

${ }^{51}$ The description of this event is found in al-Jazarī, al-Birzālī, al-Maqrīzì, al-Yūnīnī and al-'Aynī; Stewart, 2006:140-142. For different accounts of Ghazan's raid, see Amitai, 1987:244-246.

${ }^{52}$ Stewart, 2001:141-143.

53 Ibid., 140.

${ }^{54}$ Little, 1970:70-71; Crawford, 2003:202-203; Stewart, 2001:142-143.

${ }^{55}$ Hayton, 1869:198.

${ }^{56}$ Nersēs Palients', 1956:186-187.
} 
the Sultan set an ambush, filling the plain with water from two rivers. The number of Mongol and Armenian soldiers that escaped death in this quagmire was very small. ${ }^{57}$ In contrast to the Armenian sources, al-'Aynī and other Muslim historians explain Qutlughshāh's retreat by stressing the extremely inclement weather, rain and snow, which prevented Ghazan's troops from proceeding further. ${ }^{58}$

Meanwhile, Ghazan Khan sent emissaries to Amaury, the titular lord of Tyre and Constable of the Kingdom of Jerusalem in 1300 before his next campaign against Syria. The Lord of Tyre sent an expedition to Ghazan, which Jackson characterises as the first attempt by the Latin West to coordinate military activities with the Il-Khan's forces to restore Latin settlement in the Holy Land. ${ }^{59}$ Unfortunately, the Mongol army, commanded by Qutlughshāh, missed this opportunity to assist Amaury who occupied the small island of Ruad (Arwād) and was not able to resist the Mamluk army. ${ }^{60}$ The Armenian King Het'um II participated in this and the next two Mongol wars against Syria in 1300 and in 1303 but for no reward. Among the Mongol troops there were Georgio-Armenian forces headed by the Zak'arian amirspasalar Shahnshah II. ${ }^{61}$ The expeditions against the Egyptian Mamluks ended in the time of Ghazan Khan, who was not satisfied with the results of his letters sent to the masters of the Temple, the Hospital and the Teutonic Order and to Henry II of Cyprus in 1299, and to Edward I of England in 1302. ${ }^{62}$ Any hope of receiving aid from the Christian West was lost. The idea of the conquest of the Syrian coast was also lost and Ghazan died in May 1304. An interesting detail about his death is found in Nersēs Palients', who claims that the Mongol Il-Khan died because his beloved wife had poisoned him, in order to prevent him from moving against the Mamluks. ${ }^{63}$ Soon after Ghazan's death, in 1305, Het'um II abdicated

57 Ibid.

58 Stewart, 2006:147. The second expedition of Ghazan to Syria did not last long as he could not remain in Syria because of the weather (Amitai, 2005:361).

59 Jackson, 2005a:171.

60 Ibid.

${ }^{61}$ Nersēs Palients', 1956:186-87; Sebastats'i in Hakobyan, 1956:151. Ghazan Khan's last attempt to invade Syria was in 1303, but the Il-Khan did not participate himself (Amitai, 2005:361).

62 Boase, 1978:122; Jackson, 2005a:171.

63 Palients'i says that the Sultan bribed those who were very influential at Ghazan's court (Nersēs Palients', 1956:188). 
for the last time and left the throne of Cilician Armenia to his nephew, his co-ruler since 1301, Lewon IV (1305-1307). ${ }^{64}$

In Ghazan and Het'um's collaboration, Ghazan was the strong link, being successful in his internal and external affairs. Het'um's role was very passive both locally and beyond his realm. Although the Armenian monarch had an opportunity to reestablish the fading contacts with the Mongols, his domestic and external concerns and his own problematic personality did not do him any favours. The ever-vanishing chances to obtain any progress in the Near East certainly loosened the Mongol Il-Khan and Armenian Monarch's partnership.

Little is known from contemporary Armenian sources about the actual political impact of Ghazan's reign over Greater Armenia, except that the Nakhichevan area was devastated by Nawruz, and Qutlughshāh had enormous power over the Georgian King. ${ }^{65}$ Among the sources, only the colophons are explicit about Ghazan. The colophon of the Gospel of Nakhichevan says:

In this year (1304) the monarch Łazan (Ghazan Khan) departed this life and great grief befell all the peoples of the east, especially among the suffering Christian nations. May his memory be blessed and may he occupy the throne with the holy kings, because during his reign there was peace on earth as in God's paradise, (and) everywhere all taxes were removed. The Lord God gave him, as the Psalmist said, 'the justice of a king' [cf. Psalms 72:1], for he was the son of Arłun Łan (Arghun Khan), the just king, and 'the king's strength loves justice. ${ }^{.66}$

Besides his political activities, Ghazan Khan was also involved in construction projects, developing a new city quarter outside Tabriz, called Ghazaniyya, including a spectacular mausoleum for himself, a mosque, a hospice for sayyids (descendants of the Prophet), an observatory, two madrasas and other buildings. ${ }^{67}$ In addition to this, Ghazan's name is associated with initiatives on fiscal reform in Iran, which had influence on taxation policy of Greater Armenia as well. ${ }^{68}$

${ }^{64}$ Het'um Patmich', 1951:71; Nersēs Palients', 1956:182-183; Anonymous in Galstyan, 1962:79-80.

65 Step'annos Orbelian, 1910:476.

66 Sanjian, 1969:48.

67 Melville, 2003a:57.

68 For taxation in Greater Armenia, see Chapter 4. 
The Vanquished Armenian Hope: Öljeitü (r. 1304-1316) and His Armenian Counterparts

The Armenians in Cilicia were fearful of Mamluk forces crossing their territory. The Mamluks launched about ten major invasions against the Armenian Kingdom between 1266 and 1305. In 1285, the Armenians were forced to agree with humiliating conditions to pay an annual tribute to the Sultanate. ${ }^{69}$ Considerable profits from the transit trade that connected the Mongol Empire with the Mediterranean allowed the Armenians to deal with their debts. The small Mongol garrisons that functioned within the Armenian Kingdom were more active for tax collecting than providing protection. In connection with this, Mamluk offensives against Armenia lost their frequency and according to the Arabic sources, the raids were undertaken more by a $n \bar{a}^{\prime} i b$ of Aleppo, rather than by the armies of the Sultan. ${ }^{70}$

After Ghazan's reign, both Cilician Armenia and the Il-Khanate experienced moments of discord and decline, which seriously affected the Mongol-Armenian relations. This happened during the time of Ghiyāth al-Dīn Muhammad Khudā-Banda Öljeitü Khan, Ghazan's brother. In 1304, when the Mamluks raided the territory of Sis, Öljeitü succeeded to the throne. In his childhood, he was baptised and given the name of Nicholas but, in his youth, he was first converted to Buddhism and then along with his brother Ghazan he adopted Islam. ${ }^{71}$ When Öljeitü assumed the Il-Khanid throne, his name Khar-Banda (Mule Driver) was changed to Khudā-Banda (Slave of God). ${ }^{72}$

The Armenians hoped that Öljeitü would be beneficent to them, as the scribe in the Ayrarat canton notes when concluding the catechism of Cyril of Jerusalem: 'In this year (1304) the p'ashah ghan named Kharpanday ascended the throne; may Christ the King guide him to protect the Christians with piety and affability. ${ }^{73}$ However,

${ }^{69}$ Holt, 1995:92-105.

${ }^{70}$ Al-Maqrīzì, Abū al-Fidā' and Al-'Aynī in Stewart, 2001:134, 139, 148.

${ }^{71}$ Het'um Patmich', 1951:70; Golubovich, 1906:336; Pfeiffer, 1999:36-49.

${ }^{72}$ The name Kharbanda (mule driver) can be explained as the Mongol custom of protecting a child against 'bad eye' (Pfeiffer, 1999:37). According to a Muslim source, following Mongol custom, a new-born child was named after the first person to enter the place. In the case of Öljeitü, it was a mule driver (kharbanda $(h)$ ) (Ibn Battutah, 2003:77).

73 Sanjian, 1969:49. 
two years later, contrary to this, in the Commentary on the Epistles by Sargis Shorhali we find the following:

... At the same time during the patriarchate of the Lord Zak'aria, and in the Armenian year 755 (1306), during the reign of the Armenian king of Cilicia, Het'um [II], and at the conquest of the nation of archers, ... being converted to the wrong law of Mohammed, which leads along an open road to perdition, they force all to convert to their vain and false hope, they persecute and oppress and afflict, some carrying off possessions by force, some torturing, some blaspheming, insulting the cross and the church, and all of this is because of our sins ... ${ }^{74}$

As a ruler, Öljeitü desired to live in tranquillity, involving himself with completing the building of a new town, Sultānīyya, a capital residence and with erecting his mausoleum, which later would be considered a splendid example of Persian architecture. ${ }^{75}$ During his time, the long-lasting arguments between the Chinggisids finally ended. ${ }^{76}$ In his letter to Philippe de Bel in April 1305, Öljeitü confirmed that the Chinggisids had reached mutual agreement and the lands governed by the descendants of Qubilai Khan, by the Golden Horde and the Il-Khanate were joined to each other ending 45 years of recrimination..$^{77}$ Indeed, the Chinggisid rivalries over lands in Iran were eliminated by agreement between these three parties for the time being.

However, he was involved in military actions. From Sulțānīyya, he set out upon his main campaign against the inhabitants of Gĩlān in May 1307. According to Qāshānī (Kāshānī), the Gīlān conquest was provoked by a Chaghataid prince who had insulted the Il-Khan for not being able to conquer a small province in the north-west of Iran, let alone Syria..$^{78}$ Once the Il-Khan had decided to wage war on the Gīlānīs, he launched three successive expeditions led by Choban, Qutlughshāh, and by TTūghān and Mu'min. Qutlughshāh fought the main battle. With Qutlughshāh's death, Öljeitü Khan himself went to war with a royal army and subjugated the Gîlānis, demanding

${ }^{74}$ Khach'ikyan, 1950:40-41.

${ }^{75}$ Melville, 1990b:55. In Persian history, Öljeitü appears more as a patron of architecture. In addition to Sulțānīyya, he built a second capital called Sulțānabād Chamchimāl at the foot of Mount Bisitūn.

${ }^{76}$ Boyle, 1968:398.

77 Mostaert and Cleaves, 1998:86; Boyle, 1968:399; Amitai, 2005:359-390.

${ }^{78}$ Qāshānī, 1969:55-56. For different motives for Öljeitü's conquest of Gīlān in contemporary Muslim sources, see Melville, 1999b:84-87. 
obedience and the payment of taxes $(m \bar{a} l) .{ }^{79}$ This war with the Gìlānīs, as preliminary achievement for the Il-Khan, was gained at high cost, though there was another five years before his second war in 13121213. This time Öljeitü was defeated by the Mamluks.

Meanwhile, the Mongol-Cilician Armenian collaboration reached a turning point during the time of Öljeitü. After the Mamluk capture of T'il Hamdun, where a large group of Cilician Armenians had blockaded themselves, a new agreement was reached between the Armenian King and the Mamluk Sultan in July 1304, to pay two years' tribute. The Armenian monarch (the joint rule of Het'um II and Lewon IV) who expected no help from the Mongols and who was troubled constantly by substantial Mamluk raids that tried to claim delayed payment of tribute, sent his embassies to Rome and Paris in 1306. Pope Clement V (1305-1314) promised help but urged the Armenians to profess Catholicism. ${ }^{80}$ Therefore, the Armenian King and the Armenian Catholicos Grigor VII Anavarzets'i (12931307) called a council in Sis. Because Grigor VII died shortly after, his successor, Konstandin III Kesarats'i (1307-22) summoned a Synod in Sis, which confirmed the union between the Armenian and Roman Churches. ${ }^{81}$ By this, the Cilician nobles hoped to gain support from the West. However, the outcome of the synod was not welcomed either in Greater Armenia or in Cilicia. ${ }^{82}$ There was concern that the unification would possibly mean assimilation and thus would destroy the two strongholds of Armenian national life, the nobility and the church. ${ }^{83}$ Therefore, this event is considered to be the moment of decline in the history of Cilician Armenia.

The contemporary Armenian sources are, on the whole silent, about the relationship between the Mongols and the Cilician Armenians in the time of Öljeitü Il-Khan. There is a reason for this. Nersēs Palients'and the Anonymous Chronicler ${ }^{84}$ have a reference to Öljeitü. They state that, on 17 November 1307, the Armenian King Het'um II and his nephew, the teenage joint ruler King Lewon IV $^{85}$ were

${ }^{79}$ Melville, 1999b:112-113. For mal, see Chapter 4.

${ }^{80}$ Stewart, 2001:161.

${ }^{81}$ La Porta, 2007:101.

${ }^{82} \mathrm{RCH} / \mathrm{DA}, 1869(\mathrm{II}): 199$.

${ }^{83}$ Der Nersessian, 1947:15.

${ }^{84}$ Galstyan believes that this anonymous chronicler is one of the continuator of Samuel Anets'i (Samuel of Ani) (Galstyan, 1962:129[n. 210]).

${ }^{85}$ Lewon IV was a son of T'oros III, the ruler of Cilician Armenia in 1293-1298, during the period of his brother Het'um II's abdication. T'oros and Het'um II were 
murdered at the foot of the citadel in the village of Uimusunpq (Anazarbus) in Cilicia by the Mongol general Bilarghun (Bilārghū), a commander of the Mongol garrison resident in Sis. Alinakh, a brother of Het'um, went to the Mongol Khan (Öljeitü) to secure Bilarghun's death by trial. ${ }^{86}$ Various reasons for the murder have been advanced. The continuator of Anets'i claims that the Mongol general desired to make himself master of Cilicia and therefore he murdered the reigning monarch. ${ }^{87}$ According to the Arabic sources, Het'um wrote to the Il-Khan a letter informing him that one of his officials was in league with the Mamluks. Öljeitü summoned Bilarghun to the court, which was a direct threat to the latter's career. Therefore, Bilarghun had invited Het'um to a banquet and killed him with a sword. ${ }^{88}$ Despite the fact that Öljeitü later executed his commander Bilarghun, the murder of the Cilician monarch became indicative of the deteriorating Mongol-Armenian relationship.

For the time being, the Il-Khan dispatched conciliatory messages to the Mamluk Sultan. He was aiming at least to gain time while he was waiting for the response to his appeal to the Latin princes. ${ }^{89}$ Öljeitü wrote another letter to the French king but had no reply. ${ }^{90} \mathrm{~A}$ similar letter was sent to Edward I of England, which was answered by his son Edward II, firstly in a letter dated 16 October 1307 from Northampton and secondly dated 30 November from Langley. ${ }^{91}$ The English King expressed his regrets at being too geographically distant to cooperate with the Il-Khan..$^{92}$ In the second letter, Edward urged the Il-Khan to extirpate 'the Mahometan heresy. ${ }^{93}$ Pope Clement V maintained contact with Öljeitü encouraging him to assist a crusade. ${ }^{94}$ The Pope wrote to the Il-Khan on 1 March 1308:

We have noticed with pleasure, from these letters and communications, that appealing to our solicitude on behalf of the Holy Land, you have

imprisoned in 1296 by their brother Smbat (1296-1298). T'oros was killed in 1298 while Het' um II was blinded.

${ }^{86}$ Nersēs Palients', 1956:188; Anonymous in Galstyan, 1962:80-81.

87 Anonymous in Galstyan, 1962:81.

${ }^{88}$ For different versions of Het'um II's death found in Arabic and Armenian sources, see Stewart, 2001:173-179; Mikaelean, 1952:436-437.

${ }^{89}$ Boyle, 1968:399; Amitai, 2005:361.

${ }_{90}$ Mostaert and Cleaves, 1998:84-87.

${ }^{91}$ Howorth, 1970(Vol. 3):576.

${ }^{92}$ Ibid.

93 Paviot, 2000:317.

${ }_{94}$ Leopold, 2000:115. 
offered us 200,000 horses and 200,000 loads of corn which will be in Armenia [Cilicia] when the army of the Christians arrives there, and in addition to march in person with 100,000 horsemen to support the efforts of the Christians to expel the Saracens from that Holy Land. ${ }^{95}$

The Pope made no actual proposal to cooperate with the Mongol Il-Khan. The Mongol-Mamluk relation continued to be tense. ${ }^{96}$ After a long wait of responses from Latin powers, Öljeitü launched only one ill-fated invasion into Mamluk territory. In 1312-1313, the 50-year war between the Mongols and the Mamluks for the possession of Syria had ended. ${ }^{97}$

The reign of Öljeitü coincided with the reigns of Het'um II and Lewon IV, and after their deaths with Oshin (a brother of Het 'um II), who ruled the Armenian Kingdom of Cilicia from 1308 until 1320. The fairly long but interrupted series of reigns of Het'um II (1289-1293; 1295-1297; 1299-1305; 1305-1307) contributed to the downfall of the Armenian Kingdom which in practice meant the loss of territories inside and outside Cilicia. The serious conflict within the royal family caused by religious affairs affected the whole Armenian nation. Decades of intermittent war must have distracted Cilicia. Oshin had to deal with a new situation in which there was no partnership with the Mongols but a new Mamluk stability in the third reign of al-Nāșir Muhammad (1310-40). Cilicia was more open to ravages by the Mamluks and by the Turkoman tribes in Anatolia. ${ }^{98}$ After an incident in Malatya between the Armenian and Muslim population in 1315, Oshin renegotiated the terms of the treaty of 1304 with the Mamluks. The tribute was increased. ${ }^{99}$ Ongoing civil wars in Cyprus following the death of Amaury, the Lord of Tyre (1310), and their alienation from the Het'umids also affected the Kingdom. ${ }^{100}$

Öljeitü did not care much about his partnership with Cilicia. It can be said that he saw no use for this alliance anymore. The reason for this claim is that the Muslim sources say nothing about the par-

\footnotetext{
95 Boyle, 1968:403.

96 Ibid., 399. Vașșaf indicates that Öljeitü had every intention to pursue his predecessors' anti-Mamluk policy (Vașsaf, 1852-1853:472).

97 Boyle, 1968:403; Amitai, 1987:236-255.

98 Stewart, 2001:183; Amitai, 2005:365.

99 La Porta, 2007:110.

100 Stewart, 2001:183.
} 
ticipation of the Armenians in the Mongol campaigns of 1312-13. ${ }^{101}$ Öljeitü's indifference towards the Armenians and their affairs was shown in Greater Armenia as well. He pursued a harsh economic policy levying a heavy burden of kharaj on the Greater Armenians. As a result, a negative image of the Il-Khan is found in the continuator of Samuel Anets'i, who states that the whole country's economy declined sharply due to the Il-Khan's ruthless policy so that people could not afford to buy clothes and were only able to wear animal skins. ${ }^{102}$ A colophon written in Erzurum in 1314 states:

... During the khanate of Kharpanday, in grievous and bitter times, our Armenian nation fell under the yoke of levies, and there is neither hope of refuge, nor place of shelter; the whole country is suffering and subjected to taxation; and our Armenian nation was substantially reduced in number; in this city many churches were demolished; and some individuals, abandoning their faith in Christ, joined the wicked nation of the Ismaelites; and there were numerous other afflictions and sufferings everywhere on account of our sins ... ${ }^{103}$

In 1314, Öljeitü took a census in his realm. According to the Armenian colophon of Glajor monastery, the census-takers and tax collectors arrived in Vayots'-Dzor, where even one-month-old children were registered. ${ }^{104}$ Therefore, it seems quite natural to find very hostile images of Öljeitü in the Armenian sources. Öljeitü died from digestive disorders in Sultānīyya on 17 December 1316 in his 36th year. ${ }^{105}$ Armenian hopes for regaining power in the region vanished with Öljeitü.

The Aftermath of Cooperation: Lewon V (r. 1320-1341/1342) and $A b \bar{u} S a^{c} \bar{\imath} d$ (r. 1316-1335)

During the reign of the next Il-Khan Abū Sa'īd Bahatur, Öljeitü's son, a Sunnī Muslim, Cilician Armenia was ruled by Oshin I (1308$1320)$ and then by Lewon V (1320-1341). The Mamluk Sultanate was still ruled by al-Nāṣir Muhammad b. Qalwūn (1310-1340).

\footnotetext{
101 La Porta, 2007:107.

102 Anonymous in Galstyan, 1962:85.

103 Sanjian, 1969:58.

104 Ibid. For taxation and census, see Chapter 4.

105 Qazvīnī, 1915:160-161, 183.
} 
After King Het'um's murder, Oshin, who was connected through his two marriages to King Hugh III of Cyprus (1267-1284) and King Robert of Naples (1309-1343), made it his first task as a monarch to expel the Mongols from Cilician Armenia. It appears that he tried many ways to defend his country without help for 13 years before his natural death. ${ }^{106}$ After the cooperation between the Armenians and the Mongols had ended, Oshin and his successors had no other choice but to re-examine their relationship with Cyprus, their closest Christian ally, and even to establish more stable contact with the Mamluks, who did not feel directly threatened by the Muslim Mongols. ${ }^{107}$

The Il-Khanate's weakened position meant that it ceased to be so important for the Mamluk Sultans, and with the decline of the Armenian kingdom in Cilicia, Mamluk-Mongol-Armenian affairs received correspondingly less attention from the chronicles. On the whole, little attention was given in Armenian sources to the Il-Khan Abū Sa'îd who, after the death of Qutlughshāh in Gilan, retained the service of Amir Choban as commander-in-chief, ${ }^{108}$ against whom the amirs revolted in 1319. ${ }^{109}$ As Melville indicates, the events of that year were more than just rivalries between the Mongol amirs or between a young ruler and a powerful regent; they were indicators of the destruction of the kingdom. ${ }^{110}$ Among the entangled intrigues at the Il-Khanate court, ${ }^{111}$ Choban's name was connected with some episodes that occurred in Greater Armenia and in Cilicia as well.

${ }^{106}$ Chahin, 1987:291. As Abu'l-Fidā' states, when the Mamluk troops entered Cilicia in 1320, Oshin was ill and having witnessed the burning of his land, and the killing of his subjects he perished in June-July (Abu'l-Fidā', 1983:80).

107 Stewart, 2001:183; La Porta, 2007:109-110.

${ }_{108}$ Qāshānī, 1348/1969:109. On Choban, see Melville, 1999a:6-28, 1996:79-91.

109 The delay in Abū Sa'îd's coronation was due to rivalry between Amir Sevinch and Choban. Sevinch died in January 1318. In November, the Amirs Dilqandi and Ranbū were killed by Choban in Sulțānīyya. Esen Qutlugh, the governor of Khurasan, who expressed his doubts about the amirs' death, suddenly died in October 1318. Choban established himself as a leader but was not approved by many amirs, nor by the Il-Khan himself (Melville, 1997:92-96).

${ }^{110}$ Melville, 1997:114.

111 In 1318, Rashīd al-Dīn was put to death mainly because of 'Alī-Shāh's intrigues (Boyle, 1968:407). In 720 H. (1320), Abū Sa'īd in trying to end the conflicts between the ambitious amirs, wrote an edict in Sulțānīyya, addressed to the Noyans of Hundreds in Gīlān, Dashtawand and Gushtāsfī, to those appointed in Arran and Mughan, to the maliks, na'ibs and mutașarrifs, to the scribes, qäzìs and shaikhs, and to the ra'is and ra'iyats, which was a code of behaviour to avoid the use of violence in resolving personal issues (Cleaves, 1953:27-33). 
The condition of the Caucasus in general and of Greater Armenia in particular deteriorated when Abū Sa'īd experienced open hostilities from the Chaghatai Ulus and the Golden Horde in 1318/1319. ${ }^{112}$ The battle between Öz-Beg and Abū Sa'īd, assisted by Choban, occurred again in the Caucasus, near the river Kur, where the army of the Golden Horde was crushed. ${ }^{113}$ Choban punished those who did not come to assist the Il-Khan, among whom was Qurumshi (Qurumishi), the son of Alinaq in Georgia. His rebellion against Abù Sa ${ }^{\prime} i d$ in 1319 takes us to the Caucasus. The region of Geghark'unik' was devastated, churches were ruined, and children and elders were severely oppressed. However, the revolt was suppressed. Qurumshi and his army surrendered and were liquidated. ${ }^{114}$ At the beginning of 1320, Arkint, the basqaq of Gurjistan, revolted and was suppressed as well. In this battle, the northern regions of eastern Georgia and Armenia suffered enormously. ${ }^{115}$

In the following year, the officers who had been subjected to corporal punishment after the battle with Öz-Beg, sought to take revenge on Choban and they ambushed him near Lake Sevan in Armenia. Choban escaped through Tabriz to Sulțāniyya. ${ }^{116}$ The Golden Horde officers were joined by the forces of Amir Irenjin, the former governor of Diyārbakr dismissed from his office by Choban. Abū Sa'īd's personal intervention routed the enemy near Miāneh. The young Il-Khan received the title of Bahadur (hero) and Choban was rewarded by marriage to Princess Sati Beg, the Il-Khan's sister. ${ }^{117}$

112 Yasa'ur, the Chaghatai prince, revolted against the Il-Khanate to take over Māzandarān in 1319. Amir Husain, the father of Hasan-i Buzurg (1336-1356), the founder of the Jalayir dynasty, was sent to suppress Yasa'ur's revolt. Meanwhile, ÖzBeg, the ruler of the Golden Horde (1313-1341) approached Derbent in the same year. His attack on north-west Iran provided the pretext for the uprising against Choban (Melville, 1997:96).

${ }^{113}$ In 1325, Öz-Beg tried again to invade the Il-Khanate, and he was again defeated by Choban. It was only in the time of Jani-Beg (1342-1357), the son of ÖzBeg, that the Golden Horde succeeded in incorporating Azerbaijan in its territories (Boyle, 1968:408).

${ }_{114}$ Hovsep'ean, 1928:205; Manandian, 1952:320. On the revolt of the amirs in 1319, see Melville, 1997:89-115.

${ }_{115}$ Babayan, 1969:169.

116 Boyle, 1968:408.

117 Ibid., 409; Melville, 1999a:6. 
For the time being, as al-Maqrīīi suggests, in 720 H. (1321), Abū Sa ${ }^{i} \mathrm{i}$ agreed to peace with the Mamluk sultan on a seven point basis. ${ }^{118}$ There was to be:

1. No Ismāi ìli assassins dispatched from the Mamluk Sultan; ${ }^{119}$

2. No repatriation of Egyptians from the Il-Khanid territory;

3. No repatriation of the Il-Khanid subjects from Egyptian domains unless they so desired;

4. No Arab (Bedouin) or Turcomen tribes' raids on the Il-Khanid territory;

5. No restriction for merchants on the roads between two domains;

6. A grant of the royal Mamluk banner and standard for the Il-Khans' official pilgrimage to Mecca; ${ }^{120}$ and

7. No request for the repatriation of the Mamluk fugitive Qara-Sonqur, who was given asylum with the Il-Khans. ${ }^{121}$

The agreement was completed by an assurance to send a Mamluk envoy with the sultans' oath to observe the condition of peace, and the Il-Khan and his chief minister Choban should swear the same. ${ }^{122}$ Despite protest from both sides, these terms were ratified and gift exchange continued. ${ }^{123}$ Among the missions exchanged following this agreement, was an important one of 1322, when the Sultan requested

118 Al-Maqrīzī, 1941(Vol. 2):209-210; Melville, 1996a:247-263; Amitai, 2005: 367-368; Little, 2006:37.

119 Some 100 Isma'îlis are recorded as being sent to the territories of the Il-Khan to assassinate the Mamluk fugitives. During Abū Sa'īd's reign this issue had an important impact on the peace negotiations (Melville, 1996a:247-263). A group of 30 fidā'̄is was sent by al-Nāșir Muhammad with the aim of murdering Abū Sa'īd, Choban and other leading amirs (Melville, 1992:204). This request in the agreement was repeated in 1322 by the Mongol mission to Cairo (Amitai, 2005:370).

120 There had been several cases of hajj pilgrims travelling from territories under Mongol control, including the Mongols themselves (Amitai, 2005:366). The first IlKhan who encouraged pilgrimage from Iran was Ahmad Tegüder (1282-1284) (Melville, 1992:198).

121 The Sultan dispatched half a dozen assassins to kill the Mamluk renegade Qara-Sonqur, who found shelter at Öljeitü's court in 1312. Qara-Sonqur survived (Abu'l-Fidā', 1983:69). For the Sultan's various attempts to assassinate Qara-Sonqur, see Melville, 1996a:247-263.

${ }^{122}$ Little, 2006:37. Choban, as undisputed strongman of the Il-Khanate, was a more serious opponent for the Mamluks (Melville, 1996b:79-93). For details of the peace process between the Il-Khanate and Sultanate, see Amitai, 2005:373-384.

${ }_{123}$ Amitai, 2005:363-364, 370; Little, 2006:37-38. Among the gifts to the Il-Khan were girls, animals, trains ( $q$ ițär) of Bactrian camels, Anatolian horses, cheetahs, falcons, jewels, pearls and Balkash rubies, bejewelled golden belts and saddles trimmed in gold. The Egyptians received swords of various types, maces and arrows, and all kind of fabrics and cloth. Abū Sa'īd sent al-Nāșir a steel helmet engraved with a complete Qur'ān in pure gold (Little, 2006:39-40). 
that his name should be mentioned in the khutba (weekly sermon) alongside Abū Sa'îd's. ${ }^{124}$ However, the peaceful relationship established between the Il-Khan and the Sultan did not do much to help the Cilician Armenians.

Although the Mamluk raids on Cilicia lost their frequency, they targeted specific areas that would attract them in terms of profit. Thus in May to June of 1320 (Rabī' II 720) the Mamluks launched an attack on Cilician Armenia. ${ }^{125}$ In 1321, the Egyptians raided Ayas, ravaging and setting fire to the city and taking into captivity 20,000 people, and in 1322, the fortress Adana. ${ }^{126}$ Abu'l-Fidā' reports that Ayas was taken in May 1322. ${ }^{127}$ However, Nersēs Palients' attributes the sack of Ayas to 23 April of 1321. He says that the Mamluks entered the city from the seaside and cut a pass from the city into the harbour. Employing catapults, they destroyed the walls and the gate and, erecting bridges, they killed all who approached the walls. ${ }^{128}$ The King of Cyprus sent nine ships to aid the Armenians. However, as the Armenian chronicler testifies, the ships did not help the situation, as they allowed everyone to run towards the ships and to leave the city without fortification. ${ }^{129}$ Later in 1335, Ayas would experience another major Mamluk assault, which allowed the Sultan to control the port. ${ }^{130}$

In 1322/1323, Catholicos Konstantin Lambronats'i (1322-1326) was sent to al-Nāșir Muhammad to agree to peace with the Sultan. ${ }^{131}$ Maybe just before this, Pope John XXII (1316-1334) received news about the sack of Ayas with much grief and sent 30,000 florins in order to rebuild Ayas fortress. ${ }^{132}$ In fact, 37,722 florins were paid to the bankers to send to the Armenians. Some of this was used to repair the fortification in Ayas, and some to build ships in Cyprus. ${ }^{133}$ The Pope enlisted the aid of Philip V (1293-1322) of France on behalf

\footnotetext{
124 Melville, 1992:203; Melville, 1996a:254.

125 Abu'l-Fidā', 1983:79-80; Amitai, 2005:365.

126 Anonymous in Galstyan, 1962:81, 85-86.

127 Abu'l-Fidā', 1983:82.

128 Nersēs Palients', 1962:102.

129 Ibid., 102.

130 Stewart, 2001:185.

131 Anonymous in Galstyan, 1962:81.

132 Nersēs Palients', 1962:102.

133 Boase, 1978:126.
} 
of Cilician Armenia; however, the kingdom concluded a 15-year truce with the Sultan. ${ }^{134}$

Meanwhile, the conflict between the Il-Khan and the Chobanids turned into the clash of interests among the Mongol elites in Persia. ${ }^{135}$ The latter became so powerful that they were in a position to ignore the Il-Khan, so that he remained Il-Khan only in name. ${ }^{136}$ However, Abū Sa'ìd decided to assert his authority over the Chobanids. Finally, they confronted each other. ${ }^{137}$ The Armenian source states that in 1326, Abū Sa'īd 'chased Choban'138 who fled to Herat but was captured and killed and his head sent to Baghdad. ${ }^{139}$

With increasing Mongol Islamisation, an institution was inaugurated in the early fourteenth century to support the Christian Church at the Mongol court. It was during Abū Sa'îd's reign that Pope John XXII founded the archbishopric of Sultāninyya in 1318 with six suffragan sees. ${ }^{140}$ Abū Sa'īd ignored the Pope's demand to embrace Christianity but he paid some attention to the Pope's appeal to protect Christian Armenians from their Muslim neighbours. ${ }^{141}$ The corpus of letters exchanged between the Pope and the Armenian abbots and archbishops both in Greater Armenia and Cilicia witnesses the beginning of the Papacy's efforts to establish a metropolitan diocese at the Il-Khanate. ${ }^{142}$ The first letter of Pope John XXII written in Avignon on 15 October 1321, addressed to Archbishop Zak'aria of Artaz, begins as follows:

134 Ibid., 127.

135 On Teműr-Tash's aggressive military policies in Anatolia, see Melville, 2009:51-101. He started his own conquest of Cilicia, even before he was appointed as governor in Rūm. In 1317, Temür-Tash entered Cilicia and tried to invade Sis, but apart from taking many people into captivity, he was not successful (Anonymous in Galstyan, 1962:85-86). Temür-Tash recruited many Mamluks to his service. He also took off the tribute taken to the Il-Khanid treasury for himself (Abu'l-Fidā', 1983:8384). Temür-Tash was blamed by the Mamluk Sultan for breaking a peace treaty established in 1323. Besides Temür-Tash, who was reinstated in his post, Choban had another son Dimashq Khwājā, with whom Choban became the real power in the Il-Khanate (Melville, 2009:51-101).

136 Ibn Battutah, 2003:78; Abu'l-Fidā', 1983:87.

137 Melville, 1996b:88-89.

138 Anonymous in Galstyan, 1962:86.

139 Ibn Battutah, 2003:78. Because of his revenge on Choban, the Mamluk Sultan al-Nāșir Muhammad forbade the body of Choban from being buried in his mausoleum in Medina, so he was laid in Baqī's cemetery in 1329 (Melville, 1992:207).

140 Cowe, 2003/2004:49.

141 Boyle, 1968:413.

142 Cowe, 2003/2004:49. 
To our venerable brother Zacharia, Archbishop of St. Thaddeus the Apostle, ... to the Vicar of the Preachers and ... to the Custos of the Fratres Minores dwelling in the realm of the Mongols ... ${ }^{143}$

Another letter from the same Pope written on the same day was addressed to all the people in the lands of the Mongol Empire, particularly heads of state, upper nobility, and some theologians of the Southern Caucasus, whose names were listed and identified by Cowe. ${ }^{144}$ In the colophon of the Collection of Homilies written in Jerusalem in 1335, it is stated that 'this is an evil time, for the dominical places (in Jerusalem) are in captivity and are completely destroyed, and it is doubtful that they will be restored. The Christians are being insulted and trodden under the feet of the infidels. Yet, we have received the good tidings that the Franks are on the move to save the dominical sanctuaries in the Holy Land of Jerusalem. ${ }^{145}$

However, during the reign of Abū Sa'īd, the Armenians in Greater Armenia were persecuted greatly because of their faith. A colophon written in the monastery of Varag in 1318, states that the Il-Khan 'instigated by Satan, issued orders that levies should be collected from all Christians on account of their faith in Christ, and a blue sign should be sewn on the shoulders of the believers. ${ }^{146}$ Moreover, in 1334, many of the Christians within the Il-Khanate were tattooed. ${ }^{147}$

The Armenians, especially those of the later period under Mongol Il-Khanid dominion, interpreted the Mongols as God's chastisement for human sins. Thus, Vahram of Edessa in the Rhymed Chronicle laments: 'Is it just, they said, that punishment has struck us? Are we greater sinners than the other peoples of the world?' ${ }^{148}$ The Armenian manuscript colophons of the early fourteenth century are full of such sentiments. The scribe Daniel of Aght'amar describing the taxes says that 'all of this is on account of our sins. ${ }^{.149}$ An anonymous scribe was more explicit: '.. and because of our impenitence God's wrath was not abated; rather, His hand is still raised to punish and chastise

\footnotetext{
143 Ibid., 61.

144 Ibid., 64.

145 Sanjian, 1969:74.

146 Ibid., 60.

147 Anonymous in Galstyan, 1962:86.

148 RHC/DA, 1869(I):532.

149 Khach ikyan, 1950:46-48; Sanjian, 1969:52-53.
} 
us. Yet we are still unrepentant; we have become feeble and lean, emaciated and languishing, and we are nearing death and hell. ${ }^{150}$

Taxes were collected from ecclesiastics without specific instructions from the Il-Khan. For this reason, the Catholicos Zak'aria I of Aght'amar went to Baghdad and spent a whole year there to get a yarligh to exempt monks and priests from taxation. ${ }^{151}$ In the same colophon of 1318, it is stated that although the monasteries were tax-exempt, the tax-collectors terribly tortured those whom they seized and collected an enormous quantity of ducats from them. ${ }^{152}$ However, Abū Sa'īd tried to coordinate tax issues, as can be seen in his edict inscribed on the wall of Manuche mosque in Ani. ${ }^{153}$ The colophons of 1321 describe the time of Abu Sa'ìd and Choban as bitter and grievous. ${ }^{154} \mathrm{~A}$ colophon written in $\mathrm{K}^{\prime}$ ajberunik' canton in 1325 is very explicit in characterising that time:

... The Kingdom of the Arshakuni (Arsacid) dynasty had waned and weakened, as foreseen in the vision of St. Sahak. And because of our impenitence, His (God's) wrath has not abated; rather, His hand is still raised to punish and chastise us. And yet we are still unrepentant; we have become feeble, lean and languishing; we are nearing death and hell, our loins have been lowered to the ground. For the savage, strangelooking and dark-countenanced nation of archers abandoned their native faith and followed the evil sect of the forerunner of Antichrist Mahmet, and they subjected the Christians to more intense anguish and persecution. Who, indeed can recount or put into writing their tragic anguish? ${ }^{155}$

The ultimate destiny of the Cilician Armenian kingdom was strongly linked to the decline of the Il-Khanate. There were even some parallels and similarities in the biographies of their two leaders. Among the Il-Khans, the long reign of Abu Sa iid (1316-1335) corresponded with the long reign of Lewon V (1320-1341). The two monarchs both came to the throne during their early years. ${ }^{156}$ They were both under the strong influence of their regents. Lewon was brought up by Oshin of Korikos, who was against Latin influences. Due to his policy, the

${ }^{150}$ Khach 'ikyan, 1950:65, 51, 113-114; Sanjian, 1969:54, 57.

151 Sanjian, 1969:60.

152 A ducat is a gold or silver coin of varying value (Sanjian, 1969:61; Khach'ikyan, 1950:138-139).

${ }_{153}$ See Chapter 4.

154 Sanjian, 1969:63.

${ }_{155}$ Ibid., 66.

156 Melville, 1999a:11; Boase, 1978:30. 
Armenian Church was re-established in Cilicia. ${ }^{157}$ During the first decades of Abū Sa'îd's reign, Amir Choban, a devout Muslim, was effectively the ruler. ${ }^{158}$ When Lewon V came to his majority in 1329 , he showed a strong pro-Latin interest and executed his patron, Oshin of Korikos. ${ }^{159}$ When Abū Sa'ìd considered himself as Il-Khan, he inherited a Perso-Islamic government full of court intrigues, where the viziers, Rashīd al-Dīn (1317) and 'Ali-Shāh (1319) were persecuted. Abū Sa'ìd was vulnerable to powerful amirs; however, he expelled Choban and his clan. ${ }^{160}$ Lewon was married to Alice, the daughter of Oshin of Korikos; Abū Sa'īd was married to Choban's daughter, Baghdad Khatun, who held a very high position at his court. ${ }^{161}$ Both wives were killed. ${ }^{162}$ Lewon favoured a union of the Armenian and Roman Churches, which was a serious reason for the Armenian barons to revolt against him and murder him. ${ }^{163} \mathrm{Abū} \mathrm{Sa}{ }^{\mathrm{i}} \mathrm{i}$ died in the Qarabagh area in November 1335, when he went to resolve a conflict with the Golden Horde over territory in the Caucasus and Arran. ${ }^{164}$ However, it is alleged that when Abū Sa īd preferred a woman called Dilshad Khatun, whom he loved with violent passion, Baghdad Khatun out of jealousy poisoned Abū Sa'ìd and that soon after she was beaten to death by the senior Amir Kh ${ }^{w} a \bar{j} \bar{a} \mathrm{Lu}$ 'lu, a former Greek slave. ${ }^{165}$

After the deaths of the strong regent Oshin of Korikos and then of Lewon V, the Armenians in Cilicia lost both the lands they controlled outside Cilicia and the fortresses inside Cilicia. In the absence of a male Armenian heir, the barons offered the Armenian crown to Guy de Lusignan, the son of Isabel (King Oshin's sister) and Amaury (Aimery) of Cyprus in 1342. ${ }^{166}$ After the deaths of Choban and then Abū Sa'ìd, the Il-Khanid regime was shaken and became a stage for competing candidates eager to experience power. ${ }^{167}$

\footnotetext{
157 Chahin, 1987:291.

158 Melville, 1996b:81.

159 Boase, 1978:30; Chahin, 1987:291.

160 Melville, 1996b:79, 83-84, 89.

161 Abu'l-Fidā', 1983:87.

162 Lewon's second wife was Constance of Aragon, the widow of Henry II of Cyprus (Boase, 1978:30). Later, Abū Sa'īd was married to Choban's granddaughter Dilshad Khatun (Melville, 1999a:12, 16, 38).

163 Boase, 1978:30.

164 Boyle, 1968:412.

165 Ibn Battutah, 2003:78.

166 Chahin, 1987:291; Boase, 1978:30.

167 Melville, 1999a:73-74.
} 
To sum up, Het'um II and Ghazan tried to sustain the alliance established by their ancestors. During this period, even after the conversion of the Il-Khan Ghazan to Islam, Mongol interest in their Cilician partners and in their common aims in Northern Syria did not vanish completely. As one can see, the reaction of the Cilician Armenians to the Islamisation of the Mongol Il-Khans was not negative at first. The Il-Khan's policy towards the Christians was temperate as well, due to their need for Western assistance in their external affairs. On the other hand, of course, neither the Western powers, nor the Mamluks were reconciled to the Mongols' conversion.

Mongol-Armenian cooperation ended during the time of Öljeitu. The reason was that the Mongol Il-Khan was not effective in continuing war with the Mamluks. He was busy rather with his domestic affairs and wished to live in tranquillity. The consequence of this was a breakdown of the Mongol-Armenian relationship, which brought Cilician Armenia to pay increased tributes to the Sultanate, to declare the union of the Armenian and Roman Churches, and to cause Greater Armenia to suffer under a heavy burden of taxes and levies.

Under Abū Sa'îd, the next Il-Khan, there was no cooperation with the Armenians either in Cilicia or in Greater Armenia. The decline of and discord within the Il-Khanate and the Armenian kingdom in Cilicia brought no further Mongol and Armenian involvement in joint ventures. The sources show that with the decline of the Il-Khanate, the Armenian kingdom was not only more vulnerable to the Mamluks' incursions, but also lost its importance as a zone of conflict for the Mamluks. ${ }^{168}$

The Armenian kingdom of Cilicia ceased to exist in 1375. It had experienced disorder, internal strife and siege for the most part of a century. Despite this, Ayas, the heart of the kingdom, was still important to the Latins and the kings of Cyprus. The papacy finally recognised its responsibility to aid the Armenians; however, this aid did not go beyond diplomatic and financial support.

With the decline in the relationship with the Mongols, the information related to the Mongols and their affairs are less reflected in the Armenian sources. However, tax references along with the lamentations of their sins are more characteristic of the Armenian colophons. The reaction of Greater Armenia to the Islamisation of the

168 Stewart, 2001:187. 
Mongols is less clear and differs according to region. As the contemporary Armenian colophons state, those who were closer to Azerbaijan were more vulnerable to any type of religious discrimination. ${ }^{169}$ In general, the Greater Armenians experienced the worst of the turmoil caused by the wars between the Il-Khanate and the Golden Horde, which took place in Georgia and Armenia. From 1262 until 1320, the battles among the Chinggisids occurred on the shores of the River Terek, the River Kur, and the Lake Sewan and all over the Gurjistan region.

After the death of Abū Sa'ìd in 1335, the Il-Khanate became a puppet court in the hands of different Mongol grandees. Between 1335 and 1344, eight Il-Khans ascended the throne. The fierce fighting among the groups of the Mongols in Iran, which lasted about nine to ten years, ended with the collapse of the Il-Khanate and with the establishment of several independent states on its territories. Among them, the most powerful was the Chobanid state in Azerbaijan, in which Greater Armenia was initially included and which lasted until 1356; and the Jalayirid state in 'Irāq-i 'Arab with its centre in Baghdad. In the second half of the fourteenth century, after the retreat of the Golden Horde, the Jalayirids ruled the territories of the Chobanids, taking Armenia into their realm. ${ }^{170}$

169 Sanjian, 1969:63.

170 Babayan, 1969:169. 


\section{CONCLUSION}

The Mongols established a heterogeneous world empire that connected the East with the West, Shamanism and Buddhism with Islam and Christianity, and a sedentary civilisation with a nomadic existence. Within this empire, a nomadic minority, based on strong armed forces, ruled over a multi-ethnic, multicultural and multilingual population for over a century. This study suggests that, among these subject populations, the Armenians provide an example of a people that were incorporated into the Mongol Empire by establishing a close relationship with the Mongols. The Mongols dealt with the Greater Armenians along with the Georgian monarchy as a subject people, and with the Cilician Armenians, as a vassal state and allies.

Greater Armenia's geographical location as a bridge between Asia and Europe attracted the Mongols, although only the pursuit of the fugitive Khwārazmian Shah brought the Mongols to Greater Armenia, which enabled the expansion of the Mongol Empire to Asia Minor. The Mongols first came across with the Greater Armenians, whose land was supervised by separate Armenian lords, the vassals of the Georgian King. The advance of the Mongols into the Caucasus and Armenia was implemented by the Mongol noyans, who divided the Armenian lands into lots among them, thus safeguarding not only their own mobility, but also resisting their opponents' consolidation.

However, the division was informal. The Armenian lords' policy of collaborating with Mongol noyans helped them to retain their occupied lands. Therefore, Mongol rule in Greater Armenia resulted in almost no change in the lifestyle of the Greater Armenians from 1236 to $1243 .{ }^{1}$ Yeke Monggol Ulus (the Great Mongol State) built its administration in Armenia mainly using indirect rule and governing through local elites. This enabled the Armenian lords to preserve not only their lands, but also their local administration intact, although in order to prevent the resistance of their subjects and to pursue economic gain, the institution of Mongol governors, darughachis, co-existed in Armenia. This Mongol office was designed to deal

\footnotetext{
1 Bedrosian, 1979:116.
} 
with non-Mongols in non-Mongol lands and the Armenian sources confirm their function in Greater Armenia through their explicit references to the census, taxes and people who were in charge.

The impact of the Mongol financial and economic regime in Greater Armenia was certainly severe. However, in comparison with the destruction of China, Central Asia and Russia, caused by initial Mongol conquests, the Armenians' treatment looks far more merciful. This was due to the intelligence and policy of the Greater Armenian rulers, whose survival instinct led to their timely submissions.

The advance of the Mongols into Asia Minor brought them into contact with the Cilician Armenians, who voluntarily submitted to the Mongol Empire. The Cilician Armenian monarchs chose to ally with the new rising nomadic power against their hostile Muslim neighbours. The acceptance of Mongol suzerainty ensured Cilician Armenia's survival against the far more dangerous threat from the Mamluks. On the other hand, the Cilician Armenian ports on the shores of the Mediterranean Sea surely attracted the Mongols. ${ }^{2}$ Therefore, entry into the Cilician trade zone contested by different powers would be exploited by the Mongols, who preferred to have the Cilician Armenians as their ally.

Thus, by 1256, going through the different patterns of submissions, one forced, the other one willingly, the Greater and Cilician Armenians came to the same result of being subjects of the Mongol Empire, paying tributes, taxes and being obliged to provide troops and labour. However, the Cilician Armenians did not experience the economic pressures from the Mongols as the Greater Armenians did.

When the Mongol conquest extended to the shores of the Mediterranean, having destroyed both the 'Abbasid Caliphate and its Ismā îlī opponents, Hülegü demanded fresh troops for his ongoing conquests. Since the Mongol army was not salaried and relied mainly on the acquisition of booty, a large-scale mobilisation of the subject population was necessary. The role of Cilician Armenian troops

2 The commercial class of tradesmen in Cilicia allowed Cilician Armenia to participate actively in the international trade of the region. The Armenian ports contributed to the exchange of culture, science and art between eastern and western Asia, the study of which still awaits further exposition. Among the cultural exchanges during the Mongol conquest, the Armenian contribution has not been elaborated apart from the mentioning of personnel exchange of princes, clerics and merchants (Allsen, 2001:6). On the Muslim-Armenian-Mongol artistic interchanges, see Soucek, 1998:115-131. 
exceeded that of just a military tribute. The Cilician monarchs assisted the Mongol plan to conquer Syria by appealing to them to liberate the Holy Land from the Muslims, which was consistent with Mongol imperial ideology and their own ambitions.

The mobilisation of human, military and material resources accelerated the interethnic engagement that resulted in creating far-reaching and extensive cross-cultural contacts. These contacts between the Mongols and Armenians were established from the beginning of their relations. According to the Armenian sources, the process of learning about each other was evident. The Armenians' initial assumption that the Mongols were the avengers of the Christians from the tyranny of the Muslims turned out to be false. ${ }^{3}$ In due course, the Mongol noyans learned about the Armenians through their immediate contacts with them, and the mutual understanding of each other's purposes resulted in timely individual and state submissions by the Armenians and in the establishment of a military alliance, which was mutually beneficial.

Hülegü and his Greater Armenian partner the Zak'arian prince Pŕosh, and the Cilician King Het'um I not only extended the Mongol conquest into the Middle East, but also acted as implementers and partners of the alliance which was conceived to liberate the Holy Land and eliminate the Muslim supremacies in the region.

The success of the Mongol-Armenian partnership was important for Armenians in both the Caucasus and Cilicia. Although for different causes and according to different patterns, the interests of the Greater and Cilician Armenians coincided over the issues of assisting the Mongols. The strategy of the Greater Armenian lords towards the Mongol presence was cooperative, rather than confrontational, regardless of several attempts to revolt. In fact, the collaboration of Awag Zak'arian through Chormaghan with Güyük Khan, Hasan Jalal through Sartakh with Möngke Khan, Smbat Orbelian with Möngke Khan and Hülegü, and Sadun Artsruni with Hülegü and Abaqa Khan paid significant dividends for both the Armenians and the Mongols. This alliance was supported by many other factors. One of the forms of the maintenance of good relations was the forging of diplomatic marriages between the Caucasian nobility and the Mongols. ${ }^{4}$ The

\footnotetext{
3 Kirakos Gandzakets'i, 1961:202.

4 Kirakos Gandzakets'i, 1961:263, 391.
} 
sources mention several cases where the Mongols took Christian spouses.

Religion was a tool for the Mongols to implement their conquest. The Mongols' notion of world dominion is believed to have been built on their universalistic idea of being chosen by Heaven. This is especially interesting because this ideology was carried on by the descendants of Chinggis Khan even after the Mongol Empire disintegrated. The Mongols were aware that the religious questions could be an obstacle in their pursuit of conquests. Believing in only the eternal power of Heaven, they dealt with Christians and Muslims on a daily basis without any major persecutions motivated by the religion of their subjects. The Mongol governors understood that the Church in Armenia was an active part of society and that it played an important role in ensuring political and social stability within the country. Therefore, the clergy and nobles were freed from a number of obligations and from the necessity of paying some taxes. ${ }^{5}$ According to the statements of Armenian historians, the monks and lords of Greater Armenia were also employed by the Mongols as their diplomats and secretaries. ${ }^{6}$

This pragmatism extended also to treatment of the Muslims. ${ }^{7}$ Individual Muslims were posted to key positions, gaining promotion to a very high rank in the court of the Il-Khans. ${ }^{8}$ It is worth attesting that Muslim-Mongol collaboration contributed to the success of Hülegü as much as Christian-Mongol cooperation. ${ }^{9}$ Adjusting to the local tradition of conquered territories, the Mongols ruled Muslim subjects for several generations. The question of the sincerity of the Mongols' conversion to Islam is to some extent irrelevant. It could be interpreted as a tactical move in order to rule the subject majority, but whether sincere or not on a personal level, the fact remains that Islamisation did not greatly influence Chinggisid policy

${ }^{5}$ Step'annos Orbelian, 1910:412.

${ }^{6}$ Kirakos Gandzakets'i, 1961:243-252; Davit' Baghishets'i , 1956:346.

${ }^{7}$ For the careers of Turks, Khwārazmians and other people, see Rachewiltz, 1983:281-310; Endicott-West, 1989:65-88.

${ }_{8}$ The representatives of both the old bureaucratic families, like the Juvaynis, and the non-bureaucratic, like the Rashīd al-Dīns, were ministers and governors in the Il-Khanid courts and they did their best to retain Iranian governmental traditions (Morgan, 1990:110).

${ }^{9}$ Amitai-Preiss, 2004:35. 
at the Mongol court in Iran. ${ }^{10}$ This ideological re-orientation was an action prompted by political and military considerations, with the aim of retaining power over the conquered lands. The role of the Mongols in using the hostility between the Christian and Muslim religions contributed to their policy to rule the world.

It is important to note that the Mongols did not change the ethnic composition of the Armenians, unlike previous or later incursions of Arabic and Turkic tribes and dynasties. The Mongols neither assimilated with the Armenians, nor were absorbed by them. The shift of Mongol power in Greater Armenia from individual Mongol commanders to the Chinggisids, who demanded the noyans move on to Asia Minor, and who established themselves in Iran, not in Armenia, precluded the assimilation process. As has been said above, the Il-Khans ruled Greater Armenia through their governors and kept their major armies in Mughan, Arran, Rūm and Azerbaijan. Moreover, the Mongols were in a minority, being more under the threat of absorption by local customs than their subjects were to Mongol assimilation. Another factor that contributed to the Armenians' resistance to nomadic culture was their sedentary civilisation. Yet, the Armenians contributed to the consolidation of the Mongol Empire. The role of joint Mongol-Armenian forces in overthrowing the Muslim supremacies was immense.

As has been said above, among the steppe tribesmen of the thirteenth century, the Mongols were the most successful in creating a world empire. The Mongol advance into Iran and then into the Caucasus was part of the Mongol conquest of the world. Among the Chinggisids, this was also a political action to provide the offspring of the Toluids with certain lands to rule. This practical move was a cause of warfare among the Chinggisids. The wars of the Il-Khans against the Golden Horde over the pastures in the Mughan plain and Azerbaijan took place in the territories of Georgia and Greater Armenia. However, Mongol-Armenian collaboration is attested to have existed during these wars, despite the devastations of these lands.

The constant wars with the other Chinggisids halted the Il-Khans' ambition to pursue further their imperial goals. The Mongol Il-Khans' advances on the Syrian coast, regardless of the unsuitability of the 34.

${ }^{10}$ On continuity and change in Ghazan's policy after 1295, see Allsen, 2001:31- 
climate and environment, intensified the Mongol-Mamluk wars. In their fight against the Mamluks, the Armenians were their only steadfast ally. For the Armenian Kingdom of Cilicia, the alliance with the Mongols was a political move to safeguard the kingdom's autonomy. It was also the opportunity to fulfil their and the Crusaders' dreams to re-conquer Jerusalem. On this point, Cilician Armenia and the Mongols shared the same aim, which was exemplified by the conquest of Syria and Palestine. Moreover, the Latin powers were directly called upon to support the Mongol-Cilician Armenian alliance. However, in the eyes of the West, the Mongols were still viewed as the barbaric pagan hordes threatening Europe. ${ }^{11}$ When the situation in the Holy Land grew more desperate, the possibility of a general alliance between the Mongols and the West was seriously considered. ${ }^{12}$ The overall result of these affairs was that the Mamluks focused their anger on Cilician Armenia.

The hostile Mamluk attitude toward Cilician Armenia as a Mongol ally was a serious issue, in addition to the Mamluks' economic interest, which caused the Armenians to try to strengthen their ties with the Il-Khans. The Cilician Armenian position remained strong as long as the Mongols were strong in the region. The cooperation of Het'um I with Abaqa against Baybars, Lewon III with Arghun against Qalāwūn, and Het'um II with Ghazan against al-Ashraf are examples of the Mongol-Armenian partnership in practice. This partnership co-exists with a series of appeals by the Il-Khans, namely of Arghun and Öljeitu, to the Papacy and their correspondence with the Latin powers, including the kings of France and England, which remain exclusive examples of medieval diplomacy. This led to the establishment of an exceptional multi-functional relationship with different outcomes between the Mongols, Armenians, Mamluks and the Christian West.

During the reign of Ghazan Khan, the hopes of the Mongols and Cilician Armenians of receiving assistance from the Christian West and from the Pope against the Mamluks were dashed. There was no

${ }_{11}$ The devastation of Hungary in 1285 and of Poland in 1287, and the Mongol protectorates established in Rus', Bulgaria, Byzantium and Lithuania were a serious concern to the Papacy in making some decisions about the Mongol-Latin alliance (Jackson, 2005a:268-274).

${ }_{12}$ The role of the Mongols in crusading projects after 1291 has been documented by Het'um Patmich', the major source for Mongol-Latin relations (Het'um Patmich', 1988:iv). 
serious attempt to re-establish the fading Mongol-Armenian cooperation under the next two Il-Khans. Discords within the Armenian Kingdom in Cilicia and the Il-Khanate, and the peace established between the Mongol Il-Khan Abū Sa'ìd and the Mamluk Sultan al-Nās)ir Muhammad b. Qalawūn, the events strongly linked to each other, ended the Mongol-Armenian partnership. In fact, the alliance held good for more than half a century and the Armenians showed loyalty to their Mongol counterparts. They played an essential role in the multi-ethnic society of the Yeke Monggol Ulus. This study has tried to show that the issues of the Mongol-Armenian partnership deserve to be studied in their own right and on their own terms. 



\section{DYNASTIC TABLES}

\section{The Great Khans}

Chinggis

(1206-1227)

Ögedei

(1229-1241)

Güyük

(1246-1248)

Mőngke

(1251-1259)

Qubilai

(1260-1294)

The Il-Khans of Persia

Hülegü

(1256-1265)

Abaqa

(1265-1282)

Tegüder

(1282-1284)

Arghun

(1284-1291)

Geikhatu

(1291-1295)

Baidu

(1295)

Ghazan

(1295-1304)

Öljeitü

(1304-1316)

Abū Sa'īd

(1316-1335)

The Khans of the Ulus of Jochi / Golden Horde

Jochi

(d.1227)

Batu

$(1237-1255)$

Sartakh

(1256-1257)

Ulaqchi

(d. 1257)

Berke

$(1257-1267)$

Möngke-Temür

$(1267-1280)$

Tőde-Mőngke

$(1280-1287)$

Töle-Buqa

$(1287-1290)$

Toqta

$(1291-1312)$

Öz-beg

(1313-1341)

Tini-beg

Jani-beg

(1341-1342)

Berdi-beg

(1342-1357)

(1357-1359) 
The Khans Chaghatai Ulus

Chaghatai

(1227-1242)

Qara- Hülegü

(1242-1246)

Yesü-Mőngke

(1246-1251)

Orghina

(1251-1260)

Aluqu

Mubarak-shah

(1260-1265/6)

Baraq

(1266)

Negübei

(1266-1271)

(1271)

Toqa-Temür

(1272-1282)

Duwa

(1282-1307)

Kőnchek

(1308)

Taliqu/Talibuqa

(1308-1309)

Esen-Buqa

Kebek

$(1310-1318)$

(1318-1326)

Elchigidei

Duwa-Temür

(1326-1328)

(1328-1330)

Tarmashirin

(1330-1334)

Buzan

Chingshi

(1334)

(1334-1338)

Ali-Sultan

$(1338-1339)$

Yesü-Temür

(1339-1342)

Turalcha-Temür

Ghazan

$(1342-1343)$

(1343-1346)

The Armenian Kings of Cilicia

Het'um I

Lewon III

(1226-1269, d.1270)

(1269-1289)

Het'um II

Lewon IV

(1289-1293; 1295-1297;

1299-1305; joint rule

1305-1307)

Oshin I

(1305-1307)

(1308-1320)

Lewon $\mathrm{V}$

$(1320-1341)$

The Georgian Kings and Queens

Queen Tamara

(1184-1213)

Georgi IV Lasha

(1213-1223) 
Queen Rusudan

David VI Narin

David VII Ulu

Dimitri (Demetrē) II

Vakhtang II

David VIII

Georgi V

Vakhtang III

Georgi VI
(1223-1245)

(1245-1259) (King of Western

Georgia 1259-1293)

(1247-1259) (King of Eastern

Georgia 1259-1270)

(1270-1289)

(1289-1292)

(1293-1311)

(1299-1302; 1314-1346)

(1302-1308)

(1311-1313)

\section{The Mamluk Sultans}

Al-Muẓaffar Quțuz

Al-Zahir Baybars al-Bunduqdārī

Al-Sa īd Berke Khan b. Baybars

Al-Manșūr Qalāwūn b.Alfi

Al-Ashraf Khalīl b. Qalāwūn

Al-Nāṣir Muhammad b. Qalāwūn
$(657 / 1259-658 / 1260)$

$(658 / 1260-676 / 1277)$

$(676 / 1277-678 / 1279)$

(678/1279-689/1290)

(689/1290-693/1293)

(693/1293-694/1294;

698/1299-708/1309;

709/1310-741/1340) 



\section{GLOSSARY}

$\begin{array}{lll}\text { Awag } & \text { Chief } \\ \text { Balghasun } & \text { City, citadel } \\ \text { Bitikchi } & \text { Secretary } \\ \text { Catholicos } & \begin{array}{l}\text { Patriarch of the Armenian } \\ \text { Church }\end{array} \\ \text { Chengxiang } & \text { Head, chief, minister } \\ \text { Darnghachi } & \text { Resident commander, } \\ \text { governor }\end{array}$




$\begin{array}{lll}\text { Yarligh/Jarlig } & \begin{array}{l}\text { Royal decree } \\ \text { Yasa/Jasag }\end{array} \\ & \begin{array}{l}\text { Regulation issued by Mongol } \\ \text { ruler }\end{array}\end{array}$




\section{BIBLIOGRAPHY}

\section{Primary Sources}

Abu'l-Fidā', al-Malik al-Mu'ayyad 'Imād al-Dīn Ismāōil b. 'Alī (d. 1332), Al-Mukhtașar fì ta'rìkh akhbar al-bansar, 2 vols., Beirut, 1997. Partial tr. in P. Holt, The Memoirs of a Syrian Prince, Wiesbaden: Franz Steiner Verlag GmbH, 1983.

Al-'Aynī, Badr al-Dīn Mahmud b. 'Alī (d.1451),'Iqd al-jumān fì tārìkh ahl al-zamān, 4 vols., Cairo, 1987-1992.

Al-Maqrīzì, Taqī al-Dīn Aḥmad b. 'Alī (d.1442), Kìtāb al-sulūk li-ma'rifat duwal al-mulūk, eds. M. Ziyāda and S. 'Āshūr, 4 vols., Cairo, 1934-73; tr. by R. Broadhurst, A History of Ayyübid Sultans of Egypt, Boston: Twyne Publishers, 1980.

Anna Comnena, (fl.1096), The Alexiad, tr. by E. R. A. Sewter, London: Penguin Books, 1969.

Anonymous, "Chronological Tables", extracts in A. G. Galstyan (ed.), Armjanskije istochniki o Mongolakh, Moscow: Vostochnaja Literatura, 1962, 78-89.

Anonymous, Histoire de Mar Yabalaha III, Patriarche des Nestoriens et du moine Rabban Çauma, Ambassadeur du Roi Argoun en Occident (1287), tr. by J. B. Chabot, Paris: Ernest Leroux, 1895 (see Rabban Sāwmā).

Āqsarā'î, Karīm al-Dīn (ca. 723/ 1323), Musāmarat al-akhbār va musāyarat al-akhyār, Osman Turan (ed.), Ankara: Türk Tarih Kurumu Basımevi, 1944.

Banākatī, Abỉll-Faḍl M. (d.730/1329-30), Tā’rīkh-i Banākatī (717/1317), Ja'far Shi'ar (ed.), Tehran: Chāpkhāna-yi Bahman, 1348/1969; tr. by S. Weston, London, 1820.

Bar Hebraeus (d. 1286), The Chronography of Gregory Abü'l Faraj, vol. 1, New Jersey: Gorgias Press, 2003.

- The Chronography of Gregory Abū al-Faraj, tr. by Ernest A.Wallis Budge, vol. 2, London: Oxford University Press, 1932.

Davit' Baghishets'i (d.1673), "Chronicle of Davit' Baghishets'i” in V. A. Hakobyan (ed.), Minor Chronicles of the 13th-18th centuries, vol. 2, Erevan: Academy of Sciences Press, 1956, 287-349.

Dédéyan, Gerard (ed.), La Chronique Attribuée au Connétable Smbat, Paris: Librairie Orientaliste Paul Geuthner, 1980.

Eghishē (d.?) The History of Vardan and the Armenian War, A facsimile reproduction of the 1957 Erevan edition with an introduction by R. W. Thomson, Delmar, New York: Caravan Books, 1993.

Frik (fl. 13th century), Divan, T. Melik' Mushkambarean (ed.), New York: Melkonian Fund, 1952.

- Poems, Erevan: Academy of Sciences Press, 1941.

Galstyan, A. G. (ed.), Armjanskije Istochniki o Mongolakh, (Armenian Sources for the Mongols), Moscow: Vostochnaja Literatura, 1962.

. (ed.), Smbat Sparapet, Datastanagirk' (Sudebnik), Erevan: Haipetrat, 1958.

Garegin Yovsép'ian (Hovsep'ean), Colophons of Manuscripts (in Arm.), Antelias, 1951.

Gibb, H. A. R. (tr.), The Damascus Chronicle of the Crusades; The Chronicle of Ibn al-Qalānisī. London: Luzac, 1932. 
Ghewond (Łewond), History of Łewond, the Eminent Vardapet of the Armenians, Tr. int. and com. by Rev. Zaven Arzoumanian, Philadelphia: St. Sahak and St. Mesrob Armenian Church, 1982.

Grigor Aknerts'i /Grigor of Akanc'(1250-1335), History of the Tatars / History of the Nation of the Archers, Jerusalem: St. Jacob Press, 1974.

- History of the Nation of the Archers (1271/73), R .P. Frye and R. N Blake (trs. and eds.), Cambridge, Massachusetts: Harvard University Press, 1954.

Joinville and Villehardoun, Chronicles of the Crusades, tr. by M. R. B. Shaw, Harmondsworth: Penguin Classics, 1963.

Juvaynī, 'Alā' al-Dīn (623/1225-681/1283), Tasliyat al-Ikhvān, 'Abbās Māhyār (ed.), Tehran: Ābād, 1982.

—_. Ta'rikh-i Jahān-Gushā, Mīrzā Muhammad Qazvīnī (ed.), 3 vols., Tehran: Pik Irān, 1962.

- The History of the World Conqueror, ts. by J. A. Boyle, Manchester: Manchester University Press, 1997.

Jūzjānī, Minhāj b. Sirāj M. (589/1193- d. after 664/1265), Tabakāt-i- Nāṣīî̄ (657/1259- 658/1260), tr. by H. G. Raverty, W. N. Lees (ed.), 2 vols., reprint New Delhi: Oriental Books, 1970.

Hakobyan, V. A. (ed.), Minor Chronicles of the 13th-18th centuries, vol. 1, Erevan: Academy of Sciences Press, 1951, vol. 2, Erevan: Academy of Sciences Press, 1956.

Hayton/ Hethum/ Hetoum/ Het'um/ Het'um Patmich'/Het'um of Korikos (d. 1311?), "La Flor des Estoires de la Terre d'Orient" in E. Dulaurier (ed.), RHC / $D A$, Paris: Académie des Inscriptions et Belles-Lettres, 1869.

_ La Flor de las Ystorias de Orient, W. R. Long et al. (eds.), Chicago: University of Chicago Press, 1934.

- Liber Historiarum Partium Orientis, Siue Passagium Terrce Sancte, tr. by N. Salcon, M. Moltherus et al. (eds.), Haganoæ, 1529.

—. A Lytell Cronycle, tr. by Richard Pynson, Glenn Burger (ed.), Toronto: University of Toronto Press, 1988.

- History of the Tatars, tr. by M. Awgerean, Venice: St. Ghazar Press, 1842, second edn., 1951.

- "Chronicle" in Hakobyan (ed.), Minor Chronicles of the 13th-18th centuries, vol. 2, 1956, 33-93.

Herodotus, The Histories, J. T. Blanco and W. Roberts (eds.), New York, London: W. W. Norton and Company, 1992.

. The Histories of Herodotus of Halicarnassus, Harry Carter (ed.), London: Oxford University Press, 1962.

Het'um Patmich', see Hayton

Het'um II, the King (1289-1307), "Chronicles" in Hakobyan (ed.), Minor Chronicles of the 13th-18th centuries, vol. 1, 1951, 65-101; extracts in Galstyan (ed.), Armjanskije Istochniki o Mongolakh, 1962, 71-78.

Ibn al-Athīr (1160-1233), Al-Kämil fi'l-ta'rīkh, tr. by P. Juze, Baku: Azerbaijan Institute of History, 1940.

Ibn Battutah, The Travels of Ibn Battutah, tr. by Hamilton Gibb, Tim MackintoshSmith (ed.), London: Picador, 2003.

Ibn Bībī (ca. 684/1285), Al-Avāmir al-'alā'iyya fì al-umūr al-'alā'iyya, Adnan Sadık Erzi (ed.), Ankara: Türk Tarih Kurumu Basımevi, 1956/57; abbr. published by M.Th. Houtsma, in Recueil de texts relatifs à l'histoire des Seldjoucides, vol. 4, Leiden: Brill, 1902; reprint Maskūr 1971, 1-337. 
Ibn Shaddād al-H'alabī, 'Izz al-Dīn Muhammad b. 'Alī (1217-85), Description de la Syrie du Nord, tr. by Anne-Marie Edde-Terrasse, Damascus: Institut Français de Damas, 1984.

- Al-A 'lāq al-khațīra fì dhikr umarā' al-shām wa'l-jazīra. D. Sourdel (ed.), Damascus, 1953; S. Dahhān (ed.), Damascus, 1963; Y. 'Abbāra (ed.), Damascus, 1978.

Khach'ikyan, L. S. (ed.), The Colophons of the Armenian Manuscripts of the 14th century, Erevan: Academy of Sciences Press, 1950.

Kirakos Gandzakets'i (1200-1271), History of the Armenians, Melik'-Ohanjanyan (ed.), Erevan: Academy of Sciences Press, 1961.

Komroff, Manuel (ed.), Contemporaries of Marco Polo: Consisting of the Travel Records to the Eastern Parts of the World of William of Rubruck [1253-1255]; the Journey of John of Pian de Carpini [1245-1247]; the Journal of Friar Odoric [131830] and the Oriental Travels of Rabbi Benjamin of Tudela [1160-1173], New York: Dorset Press, 1989.

- The Travels of Marco Polo [the Venetian], New York: Liveright Publishing Group, 2003.

Kostaneants', K. (ed.), The Annals of the Inscription: Collection of Armenian Inscriptions, St. Petersburg: Imperial Academy of Sciences Press, 1913.

Lupprian, K., Die Beziehungen der Päpste zu Islamischen und Mongolischen Herrschern im 13.Jahrhundert Anhand Ihres Briefweschels, Vatican: Biblioteca Apostolica Vaticana, 1981.

Mandeville, John, The Travels of Sir John Mandeville, tr. by C. Moseley, London: Penguin Books, 2005.

Marco Polo, (1254-1324), The Diversity of the World, S. Badamkhatan (ed.), Mongolian tr. by B. Dorj, A. Ochir, and S. Idshinnorov, Ulaanbaatar: State Press, 1987.

. The Description of the World, New York: AMS Press, 1976.

Mat'evosyan, A. S. (ed.), The Colophons of the Armenian Manuscripts of the 13th century, Erevan: Academy of Sciences Press, 1984.

Matthew of Edessa (d. ca 1140), The Chronicle of Matthew of Edessa, tr. by Ara Edmond Dostourian, New York: University Press of America, 1993.

Matthew Paris, Chronica Majora, H. R. Luard (ed.), 7 vols., London: Longman, 1872-83.

Melikset-bek, L. (ed.), Georgian Sources about Armenia and the Armenians, 3 vols., vol. 2 (the 13-18th centuries), Erevan: State Press, 1936.

Mkhit'ar Ayrivanets'i (fl.13th-14th century), History of the Armenians, M. Emin (ed.), Moscow: Lazar Institute Press, 1860.

Mkhit'ar Gosh (1130/40-1213), The Lawcode, tr. by R. W. Thomson, AmsterdamAtlanta, GA: Rodopi, 2000.

Movses / Moses Khorenats'i (d.?), History of the Armenians, Repr. 1913 Ejmiatsin/ Tiflis edn. with int. by R. W. Thomson. Delmar, New York: Caravan Books, 1981.

Nasawī, Shihāb al-Dīn Muhammad (fl.1241), Sìrat al-Sulțān Jalāl al-Dīn Mankubirnī, Nasih 'Ali (ed.), Tehran: Sa'dī, 1366/1987, tr. by Z. M. Bunijatov, Moscow: Vostochnaja Literatura, 1996.

Nersēs Palients', (fl.14th century), "Fragments of Chronicles" in Hakobyan (ed.), Minor Chronicles of the 13th-18th centuries, vol. 2, 1956, 173-194.

- "Fragments of Chronicles" in Galstyan (ed.), Armjanskije Istochniki o Mongolakh, 1962, 92-102.

Orbeli et al., (eds.), Corpus Inscriptionum Armenicarum, 7 vols., Erevan: Academy of Sciences Press, 1960, 1966, 1973, 1977, 1982, 1996. 
Patkanov, K.P., Istorija Mongolov po Armjanskim istochnikam (The History of the Mongols in Armenian Sources), St. Petersburg: Imperial Academy of Sciences Press, 1873.

P'awstos Buzand / Buzandats'i (d.?). Buzandaran Patmut'iwnk' (The Epic Histories) also known as Patmut'iwn Hayots' (History of Armenia). A facsimile repr.1883, St. Petersburg edn., int. by Nina G. Garsoïan, Delmar, New York: Caravan Books, 1984.

Qāshānī, Abū al-Qāsim (fl.1304), Ta'rīkh-i Ūljāytū Sulțān, M. Hambly (ed.), Tehran: BTNK, 1348/1969.

Qazvīnī, Hamd Allāh Mustawfī (ca.680/1281-ca.744/1344), Zafar-Nāma (completed in 735/1334-5), Tehran: Iran University Press, 1979; Vienna, 1999.

- Nuzhat Al- Qulūb (740/1340), Mohammad Dabirsyaghi (ed.), Tehran: Tahoori, 1958.

—. Nuzhat Al- Qulūb, G. Strange (ed.), 2 vols., vol. 2, Leiden: E. J. Brill, London: Luzac, 1919.

- The geographical part of Nushat al-Qulüb, G. Strange (ed.), 2 vols., vol. 2, Leiden: E. J. Brill, London: Luzac, 1915.

—. Ta'rīkh-i Guzìda or "Select History" (730/1329-30). E. G. Browne (ed.), 2 vols., Leiden: E. J. Brill, London: Luzac, 1910, 1913.

Rabban Sāwmā (d. 1313) and Mār Yahbhallāhā III, The Monks of Kūblāi Khān, Emperor of China, tr. by E. A. W. Budge, London: Harrison \& Sons, 1928.

Rashīd al-Dīn, Faḍl Allāh (ca 645/1247-718/1318), Судрын Чуулган (Compenduim of Chronicles), Mongolian tr. by Ts. Surenkhorloo, 3 vols., Ulaanbaatar: Institute of History, 2002.

Compendium of Chronicles: A history of the Mongols, tr. by W. M. Thackston, Harvard University, vol. 1, 1998; vol. 2, 3, 1999.

_. Die Frankengeschichte des Rašì ad-Dīn, K. Jahn (ed.), Vienna, 1977, Persian text Tafel 42.

- The Successors of Genghis Khan, tr. by J. A. Boyle, New York, London: Columbia University Press, 1971.

—. Perepiska, tr. and ed. by A. I. Falina, Moscow: Nauka, 1971.

- Histoire des Mongols de la Perse, partial ed. and tr. by É. Quatremére, Paris, 1836, repr. Amsterdam: Oriental Press, 1968.

—. Jāmi' al-Tavārìkh (704/1306-710/1311), B. Karīmī (ed.), Tehran: Āqbāl, 1954. - Histoire Universelle de Rašìd al-Dīn Faḍl Allāh Abul-Khair: Histoire des Francs, K. Jahn (ed.), Leiden: Brill, 1951.

- Sbornik Letopisei (Compenduim of Chronicles), A. A. Semyonov (ed.), tr. by L. A. Khetagurov, vol. 1, part 1; tr. by O. I. Smirnova, vol.1, part 2, Moscow, Leningrad: Academy of Sciences Press, 1952.

I. P. Petrushevskii (ed.), tr. by Y. P. Verkhovsky, vol 2, Moscow, Leningrad: Academy of Sciences Press, 1960.

A. A. Romaskevich (ed.), tr. by A. K. Arends, vol 3, Moscow, Leningrad: Academy of Sciences Press, 1946.

RHC/DA. Recueil des Historiens des Croisades. Documents Arméniens, E. Dulaurier (ed.), 2 vols., Paris: Imprimerie Impériale, 1869, 1906.

RHC/OR. Recueil des Historiens des Croisades. Historiens Orientaux, vol. 1, Paris: Imprimerie Impériale, 1972.

Ross, D. and Power, E. 9Eds.), The Travels of an Alchemist; the Journey of the Taoist Ch'ang Ch'un from China to the Hindukush at the Summons of Chingiz Khan, London: George Routledge \& Sons, 1931. 
Rubrouck, Guillaume de, The Mission of Friar William of Rubruck: His Journey to the Court of Great Khan Möngke, 1253-1255, tr. by P. Jackson, London: Hakluyt Society, 1990.

Sagaster, K., Die Weisse Geshichte, Wiesbaden: Harrassowitz, 1976.

Sanjian, Avedis K. (tr.), Colophons of Armenian Manuscripts (1301-1480), Cambridge, Massachusetts: Harvard University Press, 1969.

Saint-Quentin, Simon de, Histoire Des Tartares, Jean Richard (ed.), Paris: Librairie Orientaliste Paul Geuthner, 1965.

Sauvaget, J., La Chronique de Damas d'Al-Jazari (689-698 H/ 1290-1298), Paris: Librairie Ancienne Honoré Champion, Editeur, 1949.

Sebastats'i (fl. 13th century), "Annals of Anonymous Sebastats'i" in Hakobyan (ed.), Minor Chronicles of the 13th-18th centuries, vol. 2, 1956, 115-151.

_. "Annals of Anonymous Sebastats' $i$ " in Galstyan (ed.), Armjanskije Istochniki o Mongolakh, 1962, 23-33.

Sebeos (d. after 661), The Armenian History Attributed to Sebeos, tr. with notes by R.W.Thomson, historical com. by J. Howard-Johnston, assistance from T. Greenwood, Part I, II. Liverpool: Liverpool University Press, 1999.

Secret History of the Mongols, English tr. with a historical and philological commentary by I. de Rachewiltz, The Secret History of the Mongols. A Mongolian Epic Chronicle of the Thirteenth Century, 2 vols., Leiden: Brill, 2004.

- D. Tserensodnom (ed.), Mongolyn Nuuts Tovchoo, classical Mongolian text, Ulaanbaatar: Monkhiin Useg, 2004.

- Mongolyn Nuuts Tovchoo, (edn. on Historical Military Terms and Terminologies). Ulaanbaatar: Khar Suld Press, 2004.

- Mongolyn Nuuts Tovchoo, Ulaanbaatar: Bolor Sudar Press, 2003.

. The Secret History of the Mongols: The Life and Times of Chinggis Khan, English tr. by Onon Urgunge, Richmond: Curzon, 2001.

. The Secret History of the Mongols, English tr. by F. W. Cleaves, Cambridge, Massachusetts: Harvard University Press, 1982.

- Mongolyn Nuuts Tovchoo, Tr. into modern Mongolian by Ts. Damdinsuren, Second ed., Ulaanbaatar: State Press House, 1957.

Shabānkāra'î, Muhammad ibn 'Alī ibn Muḥammad, Majma' al-ansāb, Mīr Hāsim Muhaddith (ed.), Tehran, 1363/1984.

Smbat le Connétable (1208-1276), (tr.), Assises d'Antioche, Venice: Imprimerie Arménienne Médailler, 1876.

Smbat Sparapet (1208-1276). "Chronicle” in Galstyan (ed.), Armjanskije Istochniki o Mongolakh, 1962, 47-64; in Dédéyan(ed.), La Chronique Attribuée au Connétable Smbat, 1980.

- "Letter of Smbat Constable to King of Cyprus, Henry Lusignan from Samarqand" in Galstyan (ed.), Armjanskije Istochniki o Mongolakh, 1962, 64-66.

. Datastanagirk' (Sudebnik) (The Lawcode). A. G. Galstyan (ed.), Erevan: Haipetrat, 1958.

- "Chronicle" in RHC/DA, E. Dulaurier (ed.), 1869, 643-672.

Srapyan, Armenuhi, Hovhannes Erznkats'i, Erevan: Academy of Sciences Press, 1958. Step'annos Episkopos (fl. 1290), "Annals of Step'annos Episkopos” in Hakobyan (ed.), Minor Chronicles of the 13th-18th centuries, vol. 1, 1951, 32-64.

- "Annals of Step'annos Episkopos" in Galstyan (ed.), Armjanskije Istochniki o Mongolakh, 1962, 33-43.

Step'annos Orbelian (1250/60-1304), History of Siwnik Province, K. Shahnazareants` (ed.), Paris: 1860; T'iflis: 1910.

Strabo, The Geography, tr. by H. L. Jones, London: William Heinemann Ltd, 1969. 
Tārīkh-i Āl-i Saljūq dar Ānātūlì (ca. 765/1363), Nādira Jalālī (ed.), Tehran: Āyina-yi Mīrāth 1377/1999. Also M. J. Mashkūr (ed.), Akhbār-i Salājiqa-yi Rūm. Tehran: Kitābfurūshī-yi Tihrān, 1350/1971, 343-71.

Ter-Davtyan, K.S. (ed.), Pamyatniki Armyanskoi Agiografii, (Armenian Hagiography), vol. 1, Erevan: Academy of Sciences Press, 1973.

Tizengauzen, V., (ed.), Sbornik materialov otnosjaschikhsja $k$ istorii Zolotoi Ordy, (Compendium of documents related to the Golden Horde), Moscow, Leningrad: Academy of Sciences Press, vol. 1, 1884, vol. 2, 1941.

Thomas Artsruni (fl. 10th century), History of the House of Artsrunik', Facsimile of Patkanov's ed. St. Petersburg, 1887; Int. by R. W. Thomson, Delmar, New York: Caravan Books, 1991.

Thomson, R. W. (tr.), “The Historical Compilation of Vardan Arewelc'i”, Dumbarton Oaks Papers, 43 (1989): 125-226.

Toutuo, Liao Shih, 5 vols., Beijing, 1974.

Vahram Raboun, (fl. 14th century), Chronicle of the Armenian Kingdom in Cilicia during the time of the Crusades, tr. by Charles Fried Newmann, London: J. L. Cox Print, 1831.

Vardan Arevelts'i (ca.1200 -1271), Universal History, completed in 1267, G. B. T'osunyan (ed.), Erevan: Erevan University Press, 2001.

Chronicle, int. by R. W. Thomson, Delmar, New York: Caravan Books, 1991.

Vașșāf, al-Haẓrat , Tārīkh-i Vașsẫf, microfilm No.5467, Tehran: Majlesi Library, 1962.

_. Tajziyat al-amșār wa țaziat al a'șār, M. M. Ișfahānī (ed.), 5 vols., Tehran: Ibn-i Sīnā, 1959.

—. Geschichte Wassaf's, tr. by Hammer-Purgstall, Vienna: Kaiserlich-Königlichen Hof-und Staatsdruckerei, 1856.

- Kitāb-i Tazjyat al-Amsār wa Tazjiayat al-A ‘șār, Bombay, 1269/ 1852-53.

Vaughan, Richard (ed.), The Illustrated Chronicles of Matthew Paris: Observations of Thirteenth -Century Life, Cambridge: Alan Sutton, Corpus Christi College, 1993.

Yüan Shih (The History of the Yüan Dynasty), Peking: Chung-hua Shu-chu, 1978.

\section{Secondary Literature}

Abrahamyan, A., "Bnagrakan Ditakumner Step'annos Orbelyani Patmakan Erkum" (Textual Observations in Historical Works of Step'annos Orbelyan), PatmaBanasirakan Handes, 110/3 (1985): 55-67.

Adonts, N., Armenia in the Period of Justinian, N.G. Garsoian (tr., ed.), Lisbon: Calouste Gulbenkian Foundation, 1970.

Agajanov, S. and Yuzbashian, K., "K Istorii Tjurkskikh nabegov na Armeniju v XI v." (On the History of Turkic Incursions into Armenia in the 11th c.), Palestinskii Sbornik, 13 /76 (1965): 144-58.

Aghayan, Ts. et al. (eds.), Hay Zhoghovrdi Patmut'yun (History of the Armenian People), vol. 3, Erevan: Academy of Sciences Press, 1976.

Aigle, D., "Bar Hebraeus et son Public à Travers ses Chroniques en Syriaque et en Arabe," Le Muséon, 118/1-2 (2005): 87-107.

- L'Iran face à la Domination Mongole, Tehran: Institut Français de Recherche en Iran, 1997.

Akasaka, Ts., "Özbeg as a General Term for Ulūs-i Ĵû̂ī after Islamization,” ShigakuZasshi, CIX 3 (2000): 1-39.

Akinean, N., "The Year of the death of King Het'um I," Handes Amsorya, 3-6 (1948): 269-79. 
. "Grigor k'ahanay Aknerts'i as Tatars' Historian," Handes Amsorya 3-6 (1948): 387-403.

Alishan, Gh., Shirak: Teghagrut'iwn Patkerats'oyts', Venice: St. Ghazar, 1981.

- Sisakan: Teghagrut'iwn Siwneats' Ashkharhi, Venice: St. Ghazar, 1893.

Allouche, A., “Teguder's Ultimatum to Qalawun,” IJMES, 22/ 4 (1990): 437-44.

Allsen, T., The Royal Hunt in Eurasian History, Philadelphia: Penn, University of Pennsylvania Press, 2006.

- Culture and Conquest in Mongol Eurasia, Cambridge: Cambridge University Press, 2001a.

- "Sharing out the Empire: Apportioned lands under the Mongols," in Khazanov, A. and Wink, A. (eds.), Nomads in the Sedentary World, Richmond: Curzon, 2001 b, 172-90.

- Commodity and Exchange in the Mongol Empire; A Cultural history of Islamic Textiles, Cambridge: Cambridge University Press, 1997.

_. "Mongols and North Caucasia," Archivum Eurasiae Medii Aevi 7 (19871991): 5-40.

_ "Mongolian Princes and Their Merchant Partners (1200-1260)," Asia Major, third series, v. 2, part 2, (1989): 83-126.

- Mongol Imperialism: The Policies of the Grand Qan Möngke in China, Russia and the Islamic Lands, 1251-1259, Berkeley: University of California Press, 1987. . "Guard and Government in the Reign of the Grand Qan Möngke, 1251-59," HJAS, 46. 2 (1986): 495-521.

. "The Yüan Dynasty and the Uighurs of Turfan in the 13th Century," in Morris Rossabi (ed.), China among Equals, Berkeley: University of California Press, 1983, 243-80.

_ . "Mongol Census Taking in Rus', 1245-1275," Harvard Ukrainian Studies, v. $5(1), 1981$.

Ali-Zade, A. A., Sotsial'no-Economicheskaja i Politicheskaja Istorija Azerbaijana, XIII-XIV vv. (Socio-Economic and Political History of Azerbaijan, the 13th-14th c.), Baku: Academy of Sciences, 1956.

Amitai, R., Studies in the History of the Ilkhanate, Aldershot: Ashgate /Variorum, 2007.

- "The Resolution of the Mongol-Mamluk War," in Amitai, R. and Biran, M. (eds.), Mongols, Turks and others: Eurasian Nomads and the Sedentary World, Leiden: Brill, 2005, 359-390.

- "Turco-Mongolian Nomads and the Iqțā" System in the Islamic Middle East (ca. 1000-1400 AD)," in Khazanov, A. and Wink, A. (eds.), Nomads in the Sedentary World, Richmond: Curzon, 2001 a, 152-71.

—. "The Conversion of Tegüder Ilkhan to Islam," JSAI, 25 (2001 b): 13-43.

_. "Mongol Raids into Palestine (A.D 1260 and 1300)," JRAS 2 (1987): 236-55.

Amitai-Preiss, R., Mongols and Mamluks. The Mamluk-İlkhānid War, 1260-1281, Cambridge: Cambridge University Press, 2004.

. "Ghazan, Islam and Mongol Tradition: A View from the Mamluk Sultanate," BSOAS, 59 (1996): 1-10.

—. "Ayn-Jālūt Revisited," Tārīh 2 (1992): 119-50.

Amitai, R. and Biran, M. (eds.), Mongols, Turks and others: Eurasian Nomads and the Sedentary World, Leiden: Brill, 2005.

Amitai-Preiss, R. and Morgan D. (eds.), The Mongol Empire and its Legacy, Leiden: Brill, 1999.

Anderson, B., The Spectre of Comparisons; Nationalism, Southeast Asia, and the World, London and New York: Verso, 1998. 
Anderson, E., "Thematic Variation in Two Thirteenth-Century Sources for Chinggis Qahan: The Secret History of the Mongols and Kirakos Gandzakets'i's History of the Armenians," JSAS, 15 (2006): 85-112.

Atwood, C., "The Date of the 'Secret History of the Mongols' Reconsidered," Journal of Song and Yuan Studies, 37 (2007), 1-48.

- Encyclopedia of Mongolia and the Mongolian Empire, New York: Facts on File, 2003.

Aubin, J., Émirs Mongols et Vizirs Persans dans les Remous de l'Acculturation, Paris: Association pour l'Avancement des Études Iraniennes, 1995.

Avagyan, S., Vimakan Ardzanagrut'yunneri Barak'nnut'yun (The Lexical Studies of Inscriptions), Erevan: Erevan University Press, 1978.

Avetik'yan, Z., “Step'anos Ark'episkopos Orbelyan,” Ejmiatsin, 9, 10 (1980): 22-30; 47-55.

Ayalon, D., "The Great Yāsa of Chingiz Khān. A Re-examination," Studia Islamica 33, 34, 36, 38 (1971, 1972, 1973): 7-140; 51-80; 8-58; 7-56.

- "The European Asiatic Steppe: A Major Reservoir of Power for the Islamic World," Proceedings of 25th Congress of Orientalists-Moscow 1960, Moscow, (1963) 2: 47-52.

Babayan, L., "Ŕashid-ad-Dini Taregrut'yunneri Zhoghovatsu ev nra Haykakan Aghbyurnerĕ" (Collective Chronicles of Rashīd al-Dīn and its Armenian sources), Patma-Banasirakan Handes, 2/29 (1965), 81-94.

_. Sotsial'no-economicheskaja i politicheskaja istorija Armenii v XIII-XIV vekakh. (Socio-Economic and Political History of Armenia in the 13th-14th c.), Moscow: Nauka, 1969.

- "Armenia in the Period of Mongol Dominion," HAP, v.3, Erevan: Academy of Sciences Press, 1976.

Barfield, T., The Perilous Frontier; Nomadic Empires and China 221 BC to AD 1757, Oxford: Blackwell, 1989.

Barkhudarean, S., “Arts'akh,” CIA, vol. 5, Erevan: Academy of Sciences Press, 1982.

-. "Gegharkunik'," CIA, vol. 4, Erevan: Academy of Sciences Press, 1973.

Barkhutareants', M., Patmut'yun Aghvanits' (History of Albania), Vagharshapat: Holy Ejmiatsin Press, 1902.

Barthold, V., Sochinenija, vol. 2, Moscow: Nauka, 1964.

- Sochinenija, vol. 5, Moscow: Nauka, 1968.

- Turkestan Down to the Mongol Invasion, H. A. R. Gibb (tr.), second edn., London: E. J. W. Gibb Memorial Trust, 1958; fourth edn. 1977.

_. "Persidskaja nadpis' na stene Aniiskoi mecheti Manuch'e," in Sochinenija, vol. 4, Moscow: Nauka, 1966.

Bartikyan, P., "O Vizantiiskoi aristokraticheskoi sem'ye Gavras" (On the Gavras, the Byzantine Aristocratic family), Patma-Banasirakan Handes, 3/118 (1987):190200; 4/119 (1987): 181-193; 1/120 (1988): 163-77.

Basmadjian, K., "Les Inscriptions Arméniennes d'Ani, de Bagnaïr et de Marmachén," Revue de l'Orient Chrétien, 21, 22, 26, 27 (1918-1919, 1920-1921, 1927-1928, 1929-30).

Bausani, A., "Religion under the Mongols," in J. A. Boyle (ed.), The Cambridge History of Iran; the Saljuq and Mongol Periods, vol. 5, Cambridge: Cambridge University Press, 1968.

Bazargur, D. and Enkhbayar, D., Chinggis Khan's Birth-Place and Burial Site (Historical and Geographical Researches), second edn., Ulaanbaatar: Admon, 2006.

Beckingham C. and Hamilton B., (eds.), Prester John, the Mongols and the Ten Lost Tribes, Aldershot, Hampshire: Variorum, 1996. 
Bedrossian, M., Armenian-English New Dictionary, Lebanon: Librairie du Liban, 1985.

Bedrosian, R., "Armenia during the Seljuk and Mongol Period" in, R. G. Hovannisian (ed.), The Armenian People from Ancient to Modern Times, London: Macmillan Press, 1997, 241-71.

- "China and Chinese According to 5-13 th Century Classical Armenian Sources,” Armenian Review, 34.1-133 (1981): 17-24.

_. "The Turco-Mongol Invasions and the Lords of Armenia in the 13-14th Centuries" (Ph.D diss., Columbia University, 1979).

Bedoukian, Paul, Coinage of Cilician Armenia, New York: Amer. Num. Soc, 1962.

Bergeron, P. de, and Jean N. (eds.), Voyages Faits Principalement en Asie dans les XII, XIII, XIV, et XVe siècles, vol. 1, 2, A La Haye: Chez Jean Neaulme, 1735.

Bese, L., "Some Turkic Personal Names in Secret History of the Mongols," AOASH, 32 (2) (1978): 353-369.

Bira, Sh., Ikh Mongol Ulsyn Tüüh, Üzel Surtlyn Zarim Ontslog Asuudluud (Some Problems of the History of Mongolian Statehood), Ulaanbaatar: Interpress, 2006.

__. (ed.), Mongol Sudlalyn Ögüüleliin Tüüver (Selected Articles on Mongol Studies), Ulaanbaatar: Bembi San, 2006.

"Mongolyn Tulgat Tör Baiguulagdsany Tüühen Uchir Shaltgaanyg Sudlah Asuudald" (Study of the Historical Reasons for the Origin of Mongolian Statehood), IAMS Bulletin, 36, 37 (2005-2006): 5-23.

_. "Mongolian Tenggerism and Modern Globalism. A Retrospective Outlook on Globalisation," JRAS, 14.1 (2004): 3-12.

- Mongolian Historical Writings from 1200-1700, Washington: Western Washington University, 2002.

—.Mongolyn Tü̈̈kh, Soyol, Tü̈̈kh Bichlegyn Sudlagaa (Studies in Mongolian History, Culture and Historiography), Ts. Ishdorj and Kh. Purevtogtokh (eds.), 3 vols., vol. 3, Ulaanbaatar: Interpress, 2001.

Biran, M., The Empire of the Qara Khitai in Eurasian History; between China and the Islamic World, Cambridge: Cambridge University Press, 2005.

- Qaidu and the Rise of the Independent Mongol State in Central Asia, Surrey: Curzon, 1997.

_ "The battle of Herat (1270): a case of inter-Mongol warfare," in N. Di Cosmo (ed.), Warfare in Inner Asia (500-1800), Leiden: 2002, 175-219.

Boase, T. (ed.), The Cilician Kingdom of Armenia, Edinburgh: Scottish Academic Press, 1978.

Bor, J., Bilguun Diplomatch Chinggis (Chinggis, the Wise Diplomat), second edn., Ulaanbaatar: Admon, 2004.

Borbone, P., "Barhebraeus and Juwaynī: A Syriac Chronicler and his Persian Source," Acta Mongolica, vol. 9 /320 (2009 a): 147-68.

__ " 'Saint Hulegu and Doquz Khatun': Syriac Perspectives on Mongol Rule (1314th Century Iran/Iraq)," An International Annual of Mongol Studies, vol. 22 /43 (2009 b): 102-112.

. "Some Aspects of Turco-Mongol Christianity in the Light of Literary and Epigraphic Syriac Sources," Journal of Assyrian Academic Studies, 19/2 (2005): 5-20.

- "Barhebraeus e Juwaynī: un cronista siro e la sua fonte persiana," Egitto e Vicino Oriente, XXVII (2004): 121-144.

Bournoutian, A., "Cilician Armenia," in R. G. Hovannisian (ed.), The Armenian People From Ancient to Modern Times, vol. 1, London: Macmillan, 1997, 273-90.

Boyle, J. A., The Mongol World Empire, 1206-1370, London: Variorum Reprints, 1977. 
"Some Additional Notes on the Mongolian Names in the History of the Nation of the Archers," Researches in Altaic Languages, (1975): 33-42.

_ . "Some Thoughts on the Sources for the Il-Khanid Period of Persian History," Iran, XII (1974): 185-88.

- "The Il-Khans of Persia and the Christian West," History Today, XXIII (1973): 554-63.

_. "Rashīd al-Dīn: The First World Historian," Iran, IX (1971): 19-26.

- (ed.), The Cambridge History of Iran. The Saljuq and Mongol Periods, 8 vols., vol. 5, Cambridge: Cambridge University Press, 1968.

. "The Journey of Het'um I, King of Little Armenia, to the Court of the Great Khan Möngke," Central Asiatic Journal, IX (1964): 175-89.

_. "Kirakos of Ganjak on the Mongols," CAJ, VIII (1963 a): 199-214.

. "The Longer Introduction to the Zỉj-i Ilkhānì of Nașir-ad-Dīn Ṭūsī," Journal of Semitic Studies, VIII (1963 b): 244-45.

. "The Death of the Last 'Abbāsid Caliph: a Contemporary Muslim Account," Journal of Semitic Studies, VI (1961), 145-61.

Bresc, H. and Guichard, P., "Explosions within Islam," in Robert Fossier (ed.), The Cambridge Illustrated History of the Middle Ages, 950-1250, vol. 2, Cambridge: Cambridge University Press, 1997, 146-202.

Bretschneider, E., Medieval Researches from Eastern Asiatic Sources, vol.1, London: Kegan Paul, Trench, Trubner \& Co.Ltd, 1887.

Browne, E. D., A Literary History of Persia, Tehran: Sang-e Meel Publications, 1906. Bundy, D., "Religion and Politics in the Reign of Het'um II," in N. Awde (ed.), Armenian Perspectives, Richmond: Curzon, 1997.

. "The Syriac and Armenian Christian Responses to the Islamification of the Mongols," in J. V. Tolan (ed.), Medieval Christian Perception of Islam, New York and London: Routledge, 1996, 33-53.

. "Het'um's La Flor des Estoires de La Terre d'Orient," REA 20 (1987): 223-35.

- "The Anonymous Life of Gēorg Skewrac'i in Erevan 8356: A Study in Medieval Armenian Hagiography and History," REA 18/2 (1984): 491-502.

Buell, P., "Mongol Empire and Turkicization: The Evidence of Food and Foodways," in R. Amitai-Preiss and D. Morgan (eds.), The Mongol Empire and Its Legacy, Leiden: Brill, 1999, 200-23.

— "Early Mongol expansion in Western Siberia and Turkestan (1207-1219): a reconstruction," Central Asiatic Journal, 36 (1992), 1-32.

. "Sino-Khitan Administration in Mongol Bukhara," Journal of Asian History 13.2 (1979): 121-51.

Cahen, C., The Formation of Turkey. The Seljukid Sultanate of Rum: Eleventh to Fourteenth Century, P. M. Holt (tr.), London: Longman, 2001.

—. La Turque pré-Ottomane, Istanbul and Paris: Institut Français d'Études Anatoliennes, 1988.

-Pre-Ottoman Turkey, London: Sidgwick \& Jackson, 1968.

Canard, M., "Le Royaume d'Arménie-Cilicie et les Mamlouks jusqu'au Traité de 1285," REA IV (1967): 217-259.

Chahin, M., The Kingdom of Armenia, London: Croom Helm, 1987.

Chambers, J., The Devil's Horsemen: The Mongol Invasion of Europe, London: Cassell, 1988.

Chamchiants' M., Patmut'iwn Hayots', vol. 3, Venice: Hovhann P'iatseants', 1786. Repr., Erevan, 1984.

Chamichean M., History of Armenia, Johannes Avdall (tr.), vol. 2, Calcutta: Bishop's College Press, 1827. 
Chuluunjav, D., Mongolyn Tuukhiin Filosofi (The Philosophy of Mongolian History), Ulaanbaatar: Bembi San Press, 2005.

Clauson, G., Studies in Turkic and Mongolic Linguistic, London, New York: Routledge Curson, 2002.

Cleaves, F., "The Memorial for Presenting the Yüan Shih," Asia Major, 3rd series, vol. 1, part 1 (1988): 59-70.

. "The Historicity of the Baljuna Covenant," HJAS 18, 3/4 (1955): 357-421.

. The Mongolian Names and Terms in the History of the Nation of the Archers, Cambridge, MA: Harvard University Press, 1954, 132-175.

. "Darugha and Gerege," HJAS 16, 1/2 (1953): 237-59.

. "The Mongolian Documents in the Musée de Téhéran," HJAS 16.1/2 (1953): 1-107.

- "A Chancellery Practice of the Mongols in the 13th and 14th Centuries," HJAS 14.3/4 (1951): 493-526.

Cook, M., "The Rise of the Achaemenids and the Establishment of their Empire," in Ilya Gershevitch (ed.), The Cambridge History of Iran, vol. 2, Cambridge: Cambridge University Press, 1985.

Cosmo, N. Di, "Mongols and Merchants on the Black Sea Frontier in the Thirteenth and Fourteenth Centuries: Convergences and Conflicts," in R. Amitai and M. Biran (eds.), Mongols, Turks and others: Eurasian Nomads and the Sedentary World, Leiden: Brill, 2005, 391-424.

- (ed.), Warfare in Inner Asia (500-1800), Leiden: Brill, 2002.

Cowe, P., "Relations between the Kingdoms of Vaspurakan and Ani," in R. Hovannisian (ed.), Armenian Van/Vaspurakan, California: Mazda Publishers, 2000, 73-85.

- "The Role of Correspondence in Elucidating the Intensification of LatinArmenian Ecclesiastical Interchange in the First Quarter of the Fourteenth Century," JSAS 13 (2003-2004): 47-68.

Cox, C., The Armenian Bible, New York: Diocese of the Armenian Church of America, 1996.

Crawford, P., The 'Templar of Tyre'; Part III of the 'Deeds of the Cypriots'. Aldershot: Ashgate, 2003.

Dabashi, H., "The Philosopher/Vizier: Khwāja Nașir al-Dīn al-Ṭūsī and the Isma'ilis," in F. Daftary (ed.), Medieval Isma'ili History and Thought, 1996, 321-45.

Daftary, F., A Short History of the Ismailis, Edinburgh: Edinburgh University Press, 1998.

- (ed.), Medieval Isma'ili History and Thought, Cambridge: Cambridge University Press, 1996.

—. "H'asan-i Șabbāh) and the origins of the Nizārī Isma 'ili Movement," in F. Daftary (ed.), Medieval Isma'ili History and Thought, 1996, 181-204.

- The Assassin Legends: Myths of the Ismailis, London: Tauris, 1994.

Dagvadorj, O. and Dobchinsuren, D., Mongolyn Ezent Gürnii Ih Zasgiin Tsaaz buyu Chinggis Khany Zarligiin Höh Devter, XIII Zuun (The Great Yasa of the Mongolian Empire or The Blue Annals of Chinggis Khan's Decrees, the 13th Century), Ulaanbaatar: Tsomorlig Hevlel, 2006.

Dalai, Ch. and Ishdorj, Ts., (eds.), Mongol Ulsyn Tuukh (The History of Mongolia, the 12-14th Century), 5 vols., vol. 2, Ulaanbaatar: Admon, 2003.

- Mongolyn Tuukh, 1260-1388 (The History of Mongolia, 1260-1388), N. Ishjamts (ed.), 3 vols., vol. 3, Ulaanbaatar: Erdem, 1992.

Danielian.Ē, "Taroni ev Sasuni Mamikonjanner-T’ónikyannerě /XI-XIIdd./ (The Mamikonians-Tornikians of Taron and Sasun/the 11th-12th century/)," PatmaBanasirakan Handes, vol. 2 (1979): 137-53. 
Damdinsuren, Ts., "Introduction" in Mongolyn Nuuts Tovchoo. Ulaanbaatar: State Press, 1946, 5-22.

Dawson, C. (ed.), The Mongol Mission, London and New York: Sheed and Ward, 1955.

Dédéyan, G. "Le Princes Arméniens de l'Euphratise et les Francs (c.1080-c.1150), in R. Kevorkian (ed.), Arménie, entre Orient et Occident, 1996, 164-173.

- Histoire des Arméniens, Toulouse: Privat, 1982.

Delgerjargal, P., Mongolchuudyn Ugsaa Garval (Ethnogenesis of the Mongols), Ulaanbaatar: Soyombo Printing, 2005.

DeWeese, D., "Cultural Transmission and Exchange in the Mongol Empire: Notes from the Biographical Dictionary of Ibn Al-Fuwațī," in L. Komaroff (ed.), Beyond the Legacy of Genghis Khan, Leiden-Boston: Brill, 2006, 11-29.

- Islamization and Native Religion in the Golden Horde: Baba Tükles and Conversion to Islam in Historical and Epic Tradition, Pennsylvania: Pennsylvania State University Press, 1994.

Doerfer, G., Turkische und Mongolische Elemente im Neupersischen, 3 vols. Wiesbaden: Franz Steiner Verlag GmbH, 1963, 1965, 1975.

Duceller, A., "The Twilight of Empire," in Robert Fossier (ed.), The Cambridge Illustrated History of the Middle Ages, 950-1250. Cambridge: Cambridge University Press, 1997, vol. 2, 203-328.

Dulam, S., Mongol Belgedel Zui (Mongol Symbolic System), vol. 1.Ulaanbaatar: Admon, 1999.

Eganian, M., “O Mul'ke i Mulkadarskom Prave v Armenii,” Teghekagir 11 (1958): 61-74.

Eisma, D., Mongol Rule: Reflections on Mongol Sociopolitics, Leiden: CNWS Publications, 2003.

Encyclopaedia Britannica, 15th ed. Chicago, London: Benton, 1974.

Encyclopaedia of Islam, vol. 1, Leiden: Brill, 1960.

Endicott-West, E., "Merchant Associations in Yüan China: The Ortog," Asia Major, 3rd series v.2, part 2. (1989): 127-54.

- Mongolian Rule in China, Local Administration in the Yüan Dynasty, Cambridge (Massachusetts), London: Harvard University Press, 1989.

Feodorov-Davydov, G. A., Denezhnoje delo Zolotoi Ordy (Monetary Policy of the Golden Horde), Moscow: Paleograph, 2003.

- Obschestvennyi stroi Zolotoi Ordy (Social System of the Golden Horde), Moscow: Moscow University Press, 1973.

Fletcher, J., "The Mongols: Ecological and Social Perspectives," HJAS 46, 1 (1986): 11-50.

Fossier, R. (ed.), The Cambridge Illustrated History of the Middle Ages, 950-1250, Cambridge: Cambridge University Press, vol. 2, 1997.

Fragner, B. G., "Iran under Ilkhanid Rule in a World History Respective," in D. Aigle (ed.), L'Iran Face à la Domination Mongol, Tehran, Institut Français de Recherché en Iran: 1997, 121-31.

Gaadamba, Sh., Nuuts Tovchoony Nuutsaas (Some Secrets of the Secret History), Ulaanbaatar: Ministry of Education Press, 1976.

Galstyan, A., "The First Armeno-Mongol Negotiations," The Armenian Review, 29 (1976): 26-37.

Garsoïan, N., "The Emergence of Armenia; The Arshakuni Dynasty; The Marzpanate; The Arab Invasions and the Rise of the Bagratuni (640-884); The Independent Kingdoms of Medieval Armenia; The Byzantine Annexation of the Armenian Kingdoms in the Eleventh Century," in R. Hovannisian (ed.), The Armenian 
People from Ancient to Modern Times, vol. 1, London: Macmillan Press, 1997, 37-198.

Ghazarian, J., The Armenian Kingdom in Cilicia during the Crusades, London: Curzon Press, 2000.

Golden, P., "'I will give the People unto Thee': The Činggisid Conquest and Their Aftermath in the Turkic World," JRAS 10.1 (2000): 21-41.

Golubovich, G., Biblioteca Bio-Bibliografica Della Terra Santa e Dell' Oriente Francescano, vol. 1, Quaracchi, near Firenze: Tipografia del Collegio di S. Bonaventura, 1906.

Gordlevskii, V., Gosudarstvo Seljukidov Maloi Azii (The State of Seljukids of Asia Minor), Moscow, Leningrad: Academy of Sciences Press, 1941.

Greenwood, T., "Armenian Sources," in M. Whitby (ed.), Byzantines and Crusaders in non-Greek Sources 1025-1204, Oxford: Oxford University Press, 2007, 221-252.

- "The Armenian Presence in Edessa after the Muslim Conquest," in R. Hovannisian (ed.), Armenian Tigranakert/Diarbekir and Edessa/Urfa, Costa Meza: Mazda Publishers, 2006 a, 137-152.

- "The discovery of the relics of St Grigor and the development of Armenian tradition in ninth-century Byzantium," in E. Jeffreys (ed.), Byzantine Style Religion and Civilization in Honour of Sir Steven Runciman, Cambridge; Cambridge University Press, 2006 b, 177-191.

_ "Failure of a Mission? Photius and the Armenian Church," Le Muséon 119, 1-2 (2006 c): 123-167.

. with E. Vardanyan, Hakob's Gospels: The Life and Work of an Armenian Artist of the Sixteenth Century, London: Sam Fogg, $2006 \mathrm{~d}$.

. "A Corpus of Early Medieval Armenian Inscriptions," Dumbarton Oaks Papers, 58 (2004):27-91.

_ .An unpublished Seventeenth-Century Armenian Psalter, A Constantinopolitan Scriptorium and Markos Patkerahan," Revue des Études Arméniennes, 29 (2003-2004): 323-382.

- "Sasanian Echoes and Apocalyptic Expectations: A re-evaluation of the Armenian History attributed to Sebeos," Le Muséon 115, 3-4 (2002): 323-397.

. "A History of Armenia in the Seventh and Eighth Centuries," (DPhil thesis, Oxford: 2000).

- Ass. The Armenian History attributed to Sebeos, R. Thomson (tr.), J. HowardJohnston (historical commentary), Part I, II. Liverpool: Liverpool University Press, 1999.

Grekov, B. (ed.), Ocherki istorii SSSR, Period Feodalizma (Sketches of the History of the USSR, Period of Feudalism), 2 vols., vol. 2, Moscow: Academy of Sciences Press, 1953.

Grekov, B. and Jakubovsky, A., Zolotaja Orda, B. Bystrjansky (ed.), Leningrad: Social-Economic State Press, 1937.

Grigoryan, G. M., Ocherki istorii Sjunika (Sketches of the History of Siwnik'), Erevan: Academy of Sciences Press, 1990.

Grousset, R., The Empire of the Steppes, Naomi Walford (tr.), New Brunswick, New Jersey: Rutgers University Press, 1970.

Gumilev, L. N., Searches for an Imaginary Kingdom: the Legend of the Kingdom of Prester John, R. Smith (tr.), Cambridge: Cambridge University Press, 1987.

_. "Proiskhozhdenije Sobytii" (The Origin of Events) in Mir L'va Gumiljeva, Arabeski Istorii, Moscow: Nauka, 1994.

Guseinov, P., "Istitut Atabekov" (The Institution of Atabeks), Palestinskii Sbornik 15 (78) (1966): 181-96. 
Hacikyan, A. (ed.), The Heritage of Armenian Literature, 3 vols., vol. 1, Detroit: Wayne State University Press, 2000.

Hakobyan, G., Nerses Lambronats'i, Erevan: Academy of Sciences Press, 1971.

Halfter, P., "Das Papsttum und das Königreich Georgien in der Ersten Hälfte des 13. Jahrhunderts," Le Muséon, 118 (2005):109-41.

Halperin, C., Russia and the Golden Horde, the Mongol Impact on Medieval Russian History, London: I. B. Tauris, 1985.

- "Russia and the Mongol Empire in Comparative Perspective," HJAS 43.1 (1983): 239-61.

Hambly, G., Central Asia, Hamburg: Weidenfeld and Nicolson, 1969.

Hartog, L. de, Genghis Khan, Conqueror of the World, London, New York: I. B. Tauris, 1999.

- Russia and the Mongol Yoke: the History of the Russian Principalities and the Golden Horde, 1221-1502, London, New York: I. B. Tauris, 1996.

Hastings, A., The Construction of Nationhood; Ethnicity, Religion and Nationalism, Cambridge: Cambridge University Press, 1997.

Heissig, W., The Religions of Mongolia, Geoffrey Samuel (tr.), London: Kegan Paul International, 2000.

Hewsen, R., Armenia: A Historical Atlas, Chicago: Chicago University Press, 2001.

_. "The Geography of Armenia," in R. Hovannisian (ed.), The Armenian People from Ancient to Modern Times, vol. 1, London: Macmillan, 1997, 1-17.

. "The Meliks of Eastern Armenia," REA X (1973-74): 281-300; XI (1975-76): 219-43.

Hildinger, E., Warriors of the Steppe; a Military History of Central Asia, 500 BC to 1700 AD, Cambridge, MA: Da Capo Press, 1997.

Hillenbrand, C., "The Power and Struggle between the Saljuqs and the Isma'ilis of Alamut, 487-518/ 1094-1124: The Saljuq Perspective," in F. Daftary (ed.), Medieval Isma'ili History and Thought, 1996, 205-20.

Holmgren, J., "Observation on Marriage and Inheritance Practices in Early Mongol and Yüan Society, with Particular Reference to the Levirate," Journal of Asian History 20 (1986): 127-92.

Hodgson, M., "The Ismā'ìli State," in J. A. Boyle (ed.), The Cambridge History of Iran, vol. 5, Cambridge: Cambridge University Press, 1968, 422-82.

. The Order of Assassins; the Struggle of the Early Nizārì Ismä'ìlìs against the Islamic World, Gravenhage: Mouton \& Co, 1955.

Holt, P., Early Mamluk Diplomacy (1260-1290).Treaties of Baybars and Qalāwūn with Christian Rulers, Leiden, New York: Brill, 1995.

Housley, N., The Later Crusades, 1274-1580, Oxford: Oxford University Press, 1992.

Hovannisian, R. (ed.), The Armenian People from Ancient to Modern Times, vol. 1, 2, London: Macmillan Press, 1997.

- (ed.), Armenian Van/Vaspurakan, California: Mazda Publishers, 2000.

Hovsep'ean, G., Khaghbakyank' kam Prosyank' Hayots' Patmut'yan Mej (The Khaghbakyans and the Prosyans in Armenian History), Vagharshapat: Patmagitakan Usumnasirut'yun, 1928/1969.

Howorth, H., History of the Mongols from the 9th to the 19th Century, 4 vols., vol. 2 (1), 3, and 4, Taipei: Cheng Wen Publishing Company, 1970.

Hübschmann, H., Armenische Grammatik: Armenische Etymologie, Hildesheim: Georg Olms Verlagsbuchhandlung, 1962.

Humphreys, R., From Saladin to the Mongols; the Ayyubids of Damascus, 1193-1260, New York: State University of New York Press, 1977.

Hussey, J. (ed), The Cambridge Medieval History, 4 vols., vol. 4, part 1, Cambridge: Cambridge University Press, 1966. 
Ionnisian, A., "Ustanovlenije Mongol'skogo iga v Zakavkazee" (The Establishment of Mongol Yoke in Transcaucasia), in B. Grekov (ed.), vol. 1, Moscow: Academy of Sciences Press, 1953.

Irwin, R., "What the Partridge Told the Eagle: A Neglected Arabic Source on Chinggis Khan and the Early History of the Mongols," in R. Amitai-Preiss and D. Morgan (eds.), The Mongol Empire and its Legacy, Leiden: Brill, 1999, 5-11.

Ishjamts, N., Dashtsevel, S. and Khurmetkhan, M. (eds.), Mongolyn Ezent Gurnii Gadaad Khariltsaa (External Relations of the Mongol Empire), Ulaanbaatar: Oriental Institute, 1995.

Iskanyan, V., "Artsruniats' Artagaghti masin (On the Emigration of the Artsrunids)," Patma-Banasirakan Handes 3 (1965): 67-82.

Ivanow, W., Alamut and Lamasar; Two Mediaeval Ismā'ìlì Strongholds in Iran, Tehran: Isma ili Society, 1960.

Jackson, P., "World-Conquest and Local Accommodation: Threat and Blandishment in Mongol Diplomacy," in J. Pfeiffer and S. Quinn (eds.), History and Historiography of Post-Mongol Central Asia and the Middle East, Wiesbaden: Harrassowitz Verlag, 2006 a, 3-22.

_. "Hülegü," "Ilkhans," "Möngke," "Mongols," in A.V. Murray (ed.), The Crusades. An Encyclopedia, Santa Barbara: ABC-CLIO, 4 vols., 2006 b, vol. 2, 611612; 632; vol.3, 841-847.

- The Mongols and the West, 1221-1410. London: Pearson /Longman, 2005 a.

. "The Mongols and the Faith of the Conquered," in R. Amitai and M. Biran (eds.), Mongols, Turks and others: Eurasian Nomads and the Sedentary World, Leiden: Brill, 2005 b, 245-290.

_. "Hülegü Khan and the Christians: the Making of a Myth," in P. Edbury and J. Phillips (eds.), The Experience of Crusading, 2. Defining the Crusader Kingdom, Cambridge: Cambridge University Press, 2003, 196-213.

. "Christians, Barbarians and Monsters: the European Discovery of the World beyond Islam," in P. Linehan and J. Nelson (eds.), The Medieval World, London, New York: Routledge, 2001 a, 93-110.

- "Medieval Christendom's Encounter with the Alien," Historical Research, 74 (2001 b): 347-69.

- "The State of Research, the Mongol Empire, 1986-1999," Journal of Medieval History 26.2 (2000): 189-210.

- "The Mongols and Europe," in David Abulafia (ed.), The New Cambridge Medieval History, vol. 5, Cambridge: Cambridge University Press, 1999 a, 703-19.

- "From Ulus to Khanate: the Making of the Mongol State," in R. Amitai-Preiss and D. Morgan (eds.), The Mongol Empire and its Legacy, Leiden: Brill, 1999 b, 12-38.

—. "Eljigidei," Encyclopedia Iranica, vol. 8, 1998 a, 366-67.

- "Marco Polo and his Travels," BSOAS 61 (1998 b): 82-101.

—. "Prester John Redivivus: a Review Article," JRAS 3, 7 (1997): 425-432.

. "The Crusades against the Mongols (1241)," Journal of Ecclesiastical History 42 (1991): 1-18.

. "The Mamlūk Institution in Early Muslim India," JRAS (1990 a): 340-358.

. Jalāl al-Dīn, the Mongols, and the Khwarazmian Conquest of the Panjāb and Sind," Iran (1990 b): 45-54.

—_. "Bāyjū," Encyclopedia Iranica, vol. 4, 1990 c, 1.

—_. "William Rubruck: a Review Article," JRAS (1987 a): 92-97.

—. "The Crusades of 1239-1241 and their Aftermath," BSOAS 50 (1987 b): 32-60.

. "The Crisis in the Holy Land in 1260," in G. Holmes and A. Macintyre (eds.),

The English Historical Review, vol. 95, London: Longman, 1980, 481-513. 
"The Dissolution of the Mongol Empire," CAJ 22.3-4 (1978): 186-244.

"The Accession of Qubilai Qa'an: a Reexamination," Journal of Anglo-Mongolian Society, 2 (1975): 1-10.

Jagchid, S. and Hyer, P., Mongolia's Culture and Society, Dawson: Westview Press, 1979.

- "Why the Mongolian Khans Adopted Tibetan Buddhism as Their Faith," The Third East Asian Altaistic Conference, Ch'en Chieh-hsien and J. Sechin (eds.), Taipei, 1969, 108-28.

Jamal, N., Surviving the Mongols, London: I. B. Tauris, 2002.

Jahn, K., "Rashīd al-Dīn as World Historian" Yadname-ye Jan Rypka, Prague: Academia, 1967, 79-87.

Kakabadze, S., "Ustanovlenije kriticheskogo teksta nachal'noi chasti 'Kartlis Tskhovreba' " (The Critical Text of the First Part of the 'Kartlis Tskhovreba'), Palestinskii Sbornik 15 (78) (1966): 172-80.

Kara, G., Knigi Mongol'skikh kochevnikov (Books of the Mongolian Nomads), R. Krueger (tr.), Bloomington: Indiana University, 2005.

Katouzian, H., Sa'di, The Poet of Life, Love and Compassion, Oxford: Oneworld, 2006 Kennedy, H., The Court of the Caliphs: When Baghdad Ruled the Muslim World, London: Phoenix, 2004.

- Mongols, Huns and Vikings: Nomads at War, London: Cassell, 2002.

Kevorkian, R. (ed.), Arménie, entre Orient et Occident, Paris: Bibliothèque Nationale de France, 1996.

—_. "La Diplomatie Arménienne entre l'Europe et la Perse au temps de Louis XIV," in R. Kevorkian (ed.), Arménie, entre Orient et Occident, 1996, 188-195.

Khach'atrian, A., Korpus Arabskikh nadpisei Armenii (Corpus of Armenian inscriptions, 8th-16th century), vol. 1, Erevan: Academy of Sciences Press, 1987.

Khach 'ikian, L., "Syuneats' Orbelyanneri Burt'elean Chughě" (The Burtel Branch of the Orbelians of Siwnik'), in L. Khach 'ikian, Works, vol. 2, Erevan: Gandzasar, 1999, 1-18; Banber Matenadarani 9 (1969): 173-99.

Khachikyan, L., "Mongols in Transcaucasia," Journal of World History (1958): 98-125.

Khandsuren, Ts., Tsend Gun ba Mongolyn Nuuts Tobchoo (Duke Tsend and The Secret History of the Mongols), vol. 1, Ulaanbaatar, MKHAUT Press, 1997.

Khazanov, A. and Wink, A. (eds.), Nomads in the Sedentary World, Richmond: Curzon, 2001.

Kirpichnikov, A., Voennoje delo na Rusi v XIII-XIV vv. (Military Affairs in Rus' in the 13th-14th c.), Leningrad: Nauka, 1976.

Koh Byong-ik, "Patterns of Conquest and Control by the Mongols of the 13th Century," in Ch'en Chieh-hsien and Jagchid Sechin (eds.), The Third East Asian Altaistic Conference, Taipei, 1969, 154-63.

Kolbas, J., The Mongols in Iran: Chingiz Khan to Uljaitu 1220-1309, London and New York: Routledge, 2006.

Konrad, N. Zapad i Vostok (West and East). Moscow: Vostochnaja Literatura, 1972.

Korkmaz, Z. “Tyurko-Mongol'skije obschnosti i znachenije Mongol'skogo v izuchenii Tyurkskih yazykov." (Similarities in Turco-Mongolian Languages and a Significance of the Mongolian in the Studies of Turkic Languages) Sovetskaya Tjurkologija 4 (1987): 71-78.

Korobeinikov, D., "Baiju," Enkyklopaidiko Prosopographiko Lexiko Byzantinēs Istorias kai Politismou IV (2002): 126-29.

. "The Revolt in Kastamonu, c. 1291-93," Byzantinische Forschungen XXVIII (2004): 87-118. 
“'Vladyka Konstantinopolja Velichaishego?' Tituly Vizantiiskikh imperatorov v diplomaticheskoi perepiske Musul'manskikh pravitelei v VII-X vv." (The Great Ruler of Constantinople? The titles of Byzantine Emperors in the Diplomatic Correspondence with the Muslim Rulers in the 7th-10th c), Vizantiiskije Ocherki (2006): 90-107.

Kapoïan-Kouymjian, Angèle. Appendix on Het'um the Historian in l'Égypte vue par des Arméniens, Paris: Fondation Singer-Polignac, 1988.

Kouymjian, Dickran, "The Intrusion of East Asian Imagery in Thirteenth Century Armenia: Political and Cultural Exchange along the Silk Road," The Journey of Maps and Images on the Silk Road, Philippe Forêt and Andreas Kaplony (eds.), Leiden: E. J. Brill, 2008, 119-133, pls. 12-19.

- "Chinese Motifs in Thirteenth-Century Armenian Art: The Mongol Connection," in Linda Komaroff (ed.), Beyond the Legacy of Genghis Khan, Leiden: Brill, 2006, 303-324, 524-526 (pls. 23-25), 590-599 (figs. 58-67).

- "Van under Mongol, Turkmen, Persian, and Ottoman Dominations," in R. Hovannisian (ed.), Armenian Van/Vaspurakan, California: Mazda Publishers, 2000, 87-104.

- "Chinese Influences on Armenian Miniature Painting in the Mongol Period," in D. Kouymjian (ed.), Armenian Studies/Études Arméniennes: In Memoriam Haïg Berbérian, Lisbon: Calouste Gulbenkian Foundation, 1986, 415-468.

. "Adharbayjan Based on the Islamic Coinage of the 5th/11th to the 7th/13th Centuries," PhD dissertation, Armenian Studies Program, Near and Middle Eastern Languages and Civilization,Columbia University, New York: 1969, iii, xii, 466 pages, Ann Arbor: University Microfilms, no. 70-17,025.

Kuhrt, A., The Ancient Near East: c.3000-330 BC, vol. 2, London, New York: Routledge, 1995.

Lane, G., "An Account of Gregory Bar Hebraeus Abu Al-Faraj and His Relations with the Mongols of Persia," Hugoye: Journal of Syriac Studies 2.2 (1999): 1-23.

"Arghun Aqa: Mongol Bereaucrat," Iranian Studies 32.4 (1999): 459-482.

_. Early Mongol Rule in Thirteenth-Century Iran; a Persian Renaissance. London and New York: Routledge Curzon, 2003.

Langlois, J., China under Mongol Rule. Princeton: Princeton University Press, 1981.

Langlois, V. Le Trésor des Chartes d'Arménie ou Cartulaire de la Chancellerie Royale des Roupéniens. Venice: Saint Lazare Press, 1862.

Lambton, A., Continuity and Change in Medieval Persia: Aspects of Administrative, Economic and Social History, 11th-14th Century, Albany: Persian Heritage Foundation, 1988.

- "Mongol Fiscal Administration in Persia," Studia Islamica LXIV and LXV (1986-1987): 79-99; 97-123.

. State and Government in Medieval Islam. London Oriental Series, London: Oxford University Press, 1981.

- Landlord and Peasant in Persia, London: Oxford University Press, 1953.

La Porta, S., "The Armenian Episcopacy in Mamluk Jerusalem in the Aftermath of the Council of Sis (1307)," JRAS 17.2 (2007): 99-114.

Lattimore, O., Desert Road to Turkestan, Second edn., New York: Kodansha International, 1995.

—. High Tartary, New York: Kodansha International, 1994.

-. Inner Asian Frontiers of Asia, Oxford: Oxford University Press, 1989.

-. Mongol Journeys, New York: Doubleday, 1941.

Leopold, A., How to Recover the Holy Land; the Crusade Proposals of the Late Thirteenth and Early Fourteenth Century, Aldershot: Ashgate, 2000. 
Lessing, F. (ed.), Mongolian-English Dictionary, Bloomington, Indiana: The Mongolian Society, 1973.

Lewis, B., The Assassins: A Radical Sect in Islam, London: Phoenix, 2003.

Liddell H., Great Captains Unveiled, Edinburgh, London: William Blackwood \& Sons Ltd, 1927.

Lint, Th. M. van, "Europe beyond Europe: The Case of Armenia and the Armenians," in P. Deproost and B. Coulie (eds.), Les Frontières pour Ouvrir L'Europe, Paris: L'Harmattan, 2004, 153-78.

. "Seeking Meaning in Catastrophe: Nersēs Šnorhali's Lament on Edessa," in K. Ciggaar and H. Teuke (eds.), East and West in the Crusader States, Leuven: Uitgeverij Peeters, 1999, 29-105.

Lister, R., The Secret History of Chenghis Khan, London: Peter Davies, 1969.

Little, D., "Diplomatic Missions and Gifts Exchanged by Mamluks and Ilkhans," in L. Komaroff, Beyond the Legacy of Genghis Khan, Leiden-Boston: Brill, 2006, $30-42$.

- An Introduction to Mamlūk Historiography, Wiesbaden: Franz Steiner Verlag GMBH, 1970.

Lloyd, S., English Society and the Crusades, Oxford: Clarendon Press, 1988.

Luisetto, F., Arméniens \& autres chrétiens d'Orient sous la domination Mongole, Paris: Geuthner, 2007.

Luvsanbaldan, Kh., "Mongol Irakiin Bökhiin Sportyn Hariltsaany tuhai Tüühen Medee" (Historical Information on the Sportive Relationship between Mongolia and Iraq), in L Enkbaatar (ed.), Khaltaryn Luvsanbaldan, Ulaanbaatar: Admon, 2006, 71-72.

Maenchen-Helfen, O., The World of the Huns: Studies on Their History and Culture, Berkeley, London: University of California Press, 1973.

Manandian, H., The Trade and Cities of Armenia in Relation to Ancient World Trade, N. G. Garsoïan (tr.), Lisbon: Livraria Bertrand, 1965.

- K'nnakan Tesut'yun Hay Zhoghovrdi Patmut'yan (Critical View of the History of the Armenian People), vol. 3, Erevan: Academy of Sciences Press, 1952.

Mantran, R., "Islam Dethroned," in Robert Fossier (ed.), The Cambridge Illustrated History of the Middle Ages, 950-1250, vol. 2, Cambridge: Cambridge University Press, 1997, 449-88.

Manz, B., The Rise and Rule of Tamerlane, Cambridge: Cambridge University Press, 1999.

Marr, N., "Armjane-Khalkedonity," in P. Muradyan (ed.), The Caucasian Cultural World and Armenia, Erevan:Gandzasar, 1995, 209-86.

Marshall, R., Storm from the East, London: Penguin Books, 1994.

Martinez, A. "The İl-Xānid Army," Archivum Eurasie Medii Aevi, IV (1986[1988]): 129-242.

Mathews, T. and Wieck, R., Treasures in Heaven, Armenian Art, Religion and Society. New York: The Pierpont Morgan Library, 1998.

May, T., "A Mongol-Ismā'îlì Alliance? Thoughts on the Mongols and Assassins," JRAS 14, 3/3 (2004): 231-39.

- "The Mongol Presence and Impact in the Lands of the Eastern Mediterranean," in D. Kagay, and L. Villalon (eds.), Crusaders, Condottieri, and Cannon, Leiden, Boston: Brill, 2003.

"Attitudes towards Conversion among the Elite in the Mongol Empire," E-ASPAC, (2002): 1-23.

. "Chormaghan Noyan: The First Mongol Governor in the Middle East," (MA thesis, Indiana University, 1996). 
Melik'-Bakhsyan, S., "Ditoghut'yunner Arabneri: Hayastan Katarats Aŕajin Arshavank'neri masin (Notes on the First Arab Conquests of Armenia)," PatmaBanasirakan Handes 3 (1964): 79-90.

Melville, C., "Anatolia under the Mongols," in K. Fleet (ed.), Cambridge History of Turkey. Byzantium to Turkey, 1071-1453, Cambridge: Cambridge University Press, 2009, 51-101.

_. "Jāme'al-Tawārikh,” Encyclopedia Iranica XIV/4 (2008 a): 462-68.

. "Jahangosā-ye Jovaynī," Encyclopedia Iranica XIV/5 (2008 b): 378-82.

"From Adam to Abaqa: Qāḍi Baiḍāwīs Rearrangement of History" Part I, II, Studia Iranica 30/1 (2001): 67-86; 36 (2007): 7-64.

. "The Kheshig in Iran: The Survival of the Royal Mongol Household," in L. Komaroff (ed.), Beyond the Legacy of Genghis Khan, Leiden-Boston: Brill, 2006a, 135-63.

_ . "The Early Persian Historiography of Anatolia," in J. Pfeiffer and S. Quinn (eds.), History and Historiography of Post-Mongol Central Asia and the Middle East, Wiesbaden: Harrassowitz Verlag, 2006 b, 135-66.

. "The Mongols in Iran," in Komaroff and Carboni (eds.), The Legacy of Genghis Khan; Courtly Art and Culture in Western Asia, 1256-1353, London: Yale University Press, 2003 a, 37-61.

_. "H'amd-Allāh Mostawfi," Encyclopaedia Iranica XI (2003 b): 631-34.

- The Fall of Amir Chupan and the Decline of the Ilkhanate, 1327-37; A Decade of Discord in Mongol Iran, (Papers on Inner Asia, 30), Bloomington: Indiana University, Research Institute for Inner Asian Studies, 1999 a. . "The İlkhān Öljeitü’s Conquest of Gīlān (1307): Rumour and Reality," in R. Amitai-Preiss and D. Morgan (eds.), The Mongol Empire and its Legacy, Leiden: Brill, 1999 b, 73-125.

. "H'amd Allāh Mustawfi's Zafarnāmah and the Historiography of the Late Ilkhanid Period," in K. Eslami (ed.), Iran and Iranian Studies, Princeton: Zagros, 1998, 1-11.

—. "Abū Sa'ĩd and the Revolt of the Amirs in 1319," in D. Aigle (ed.), L'Iran Face à la Domination Mongole, Tehran, Institut Français de Recherche en Iran: 1997, 89-120.

_. " 'Sometimes by the Sword, Sometimes by the Dagger': The Role of Ismā' îli s in Mamlūk-Mongol Relations in the 8th /14th Century," in F. Daftary (ed.), Medieval Ismā'ì ì History and Thought, Cambridge, 1996 a, 247-63.

. "Wolf or Shepherd? Amir Chupan's Attitude to Government," in J. Raby and

T. Fitzherbert (eds.), The Court of the Il-Khans, 1290-1340, Oxford: Oxford University Press, 1996 b, 79-93.

—. "Doquz Khatun," Encyclopaedia Iranica VII (1996 c): 475-76.

. "The Year of the Elephant': Mamluk-Mongol Rivalry in the Hejaz in the Reign of Abū Sa'īd (1317-1335),” Studia Iranica 21 (1992): 197-214.

_ "Pādshāh-i Islām: the Conversion of Sultan Maḥmūd Ghāzān Khān," Pembroke Papers, C. Melville (ed.), vol. 1, Cambridge: University of Cambridge, 1990 a, 159-77.

—. “The Itineraries of Sultan Öljeitü, 1304-16," Iran 28 (1990 b): 55-70.

Meyvaert, P., "An Unknown Letter of Hulagu, Il-Khan of Persia, to King Louis IX of France," Viator 11 (1980): 245-61.

Mikaelean, G., Istorija Kilikiiskogo Armjanskogo gosudarstva (History of Cilician Armenian Kingdom), Erevan: Academy of Sciences Press, 1952.

Minorsky, V., The Turks, Iran and the Caucasus in the Middle Ages, London: Variorum Reprints, 1978. 
. “Nașīr al-Dīn Ṭūsī on Finance,” BSOAS, Vol.10, 1940-42, 755-89; Iranica 775 (1964 a): 64-85.

—. "Twenty Articles," Iranica, Tehran: University of Tehran, 1964 b.

. "Pūr-i Bahā's 'Mongol Ode'," Iranica (1964 c): 274-91.

"Pūr-i Bahā and his Poems," Iranica (1964 d): 292-305.

Studies in Caucasian History, London: Taylor's Foreign Press, 1953.

- A Manual of Șafavid Administration, Persian Text in Facsimile (BM. Or. 9496), London: 1943.

Mongolyn Uran Zohiolyn Deejis, Zuun Bilig Orshivoi (The Creams of Mongolian Literature), Ulaanbaatar: State Press, 1959.

Morgan, D. "The Mongols in Iran: A Reappraisal," Iran XLII (2004): 131-36.

_ . "Ibn Bațtututa and the Mongols," JRAS 2.1 (2001): 1-11.

. "Prester John and the Mongols," in C. Beckingham and B. Hamilton (eds.),

Prester John, the Mongols and the Ten Lost Tribes, Aldershot, Hampshire:

Variorum, 1996.

- The Mongols, Oxford: Blackwell, 1990.

- Medieval Persia 1040-1797, London: Longman, 1988.

. "The Great Yāsā of Chingiz Khān' and Mongol Law in the İlkhānate," BSOAS

48.1 (1986): 163-76.

"Who Ran the Mongol Empire?," JRAS (1982 a): 124-36.

. (ed.), Medieval Historical Writing in the Christian and Islamic Worlds, London: SOAS, $1982 \mathrm{~b}$.

Morgan, J. de, The History of the Armenian People. From the Remotest Times to the Present Day, Ernest F. Barry (tr.), Boston, Massachusetts: Hairenik Press, 1949.

Mostaert, A. and Cleaves, F. (eds.), Ilkhaan Argun, Ölziit naraas 1289, 1305 ond Goo Filippt Ilgeesen Zahidluud (Letters of the Il-Khans Arghun and Öljeitu to Philip the Fair), T. Tömörkhuleg (tr.), Ulaanbaatar: Mongol Sudlal, 1998.

Les Lettres de 1289 et 1305 des Ilkhan Aryun et Öljeitu à Philippe le Bel, Scripta Mongolica Monograph Series I, Cambridge, MA: Harvard-Yenching Institute, 1962.

Muginov, A., "Persidskaja unikal'naja rukopis' Rashīd ad-Dīna," Uchjenyje Zapiski Instituta Vostokovedenija XVI (1958): 353-75.

Munkuev, N., Kitaiskii istochnik o pervykh Mongol'skikh Khanakh, Moscow: Nauka, 1965.

Muradyan, P., Armjanskaja epigrafika Gruzii; Kartli i Kakheti, Erevan: Academy of Sciences Press, 1985.

_. Armjanskaja epigrafika Gruzii; Tbilisi, Erevan: Academy of Sciences Press, 1988.

Mushegyan, Kh., "A Gold Coin of Cilician Armenia in the Hermitage," PatmaBanasirakan Handes 2 (29) (1965): 205-06.

Mutafian, Claude. "Trente-six erreurs concernant l'Arménie cilicienne (XIIIe-XIVe siècle)," in B. Der Mugrdechian (ed.), Between Paris and Fresno: Armenian Studies in Honor of Dickran Kouymjian, Costa Mesa, CA: Mazda Publishers, 2008, p. 361-378.

—. La Cilicie au Carrefour des Empires, Erevan: Nairi, 2001.

—. (ed.), Roma-Armenia, Rome: Edizioni de Luca, 1999.

—. "Le Siècle Mongol (1220-1320), Planche de Salut ou Coup de Grâce?," in R. Kevorkian (ed.), Arménie, entre Orient et Occident, 1996, 174-183.

Nagaanbuu, N. Besuudei, "Mongolyn Tüüh Soyolyn Ner Tomyony Gargalgaa” (The Interpretation of Mongolian Historical and Cultural Terms), in Kh Sampildendev (ed.), XIII zuuny Erdem Soyol (The Knowledge and Culture of the 13th century), Ulaanbaatar: Öngöt Hevlel, 2005. 
Nasonov, A. N., Mongoly i Rus'; Istorija Tatarskoi politiki na Rusi (The Mongols and Rus'; History of Tatars' Policy in Rus'), Moscow-Leningrad: Academy of Sciences Press, 1940.

Nicol, D., The Last Centuries of Byzantium, 1261-1453, Second edn., Cambridge: Cambridge University Press, 1993.

Der Nersessian, S., "The Kingdom of Cilician Armenia," Byzantine and Armenian Studies, vol. 1, Louvain: Imprimerie Orientaliste, 1973 a; Academy of Sciences Press, 1988, 329-52.

_. "The Armenian Chronicle of the Constable Smbad or of the 'Royal Historian'," Byzantine and Armenian Studies, vol. 1, Louvain: Imprimerie Orientaliste, 1973b, 353-377.

- The Armenians, London: Thames and Hudson, 1969.

. "The Kingdom of Cilician Armenia," in Kenneth M Setton (ed.), A History of the Crusades, vol. 2, Philadelphia: University of Pennsylvania Press, 1962, 44-71.

- Armenia and the Byzantine Empire; A Brief Study of Armenian Art and Civilization, Cambridge, MA: Harvard University Press, 1947.

Ochir, A., "Temüjiny Törsön Sar Ödriin tuhai" (About Temüjin's Birth Month and Day), IAMS Bulletin 36, 37 (2005-2006): 46-51.

D’Ohsson, A.. Histoire des Mongols depuis Tchinguiz-Khan jusqu'à Timour Bey Ou Tamerlan, 4 vols., Amsterdam: F.Muller, 1852.

Okladnikov, A.(ed.), Istorija Mongol'skoi Narodnoi Respubliki, Moscow: Nauka, 1983.

Orbeli, I., Izbrannye Trudy, Erevan: Academy of Sciences Press, 1963.

Ostrowski, D., "The 'tamma' and the Dual-Administrative Structure of the Mongol Empire," BSOAS, 61, 2, (1998): 262-77.

_. "The Mongol Origins of Moscovite Political Institutions," Slavic Review, 49, 4 (1990): 525-42.

The Oxford Classical Dictionary (OCD), Simon Hornblower and Antony Spawforth (eds.), Third edn., Oxford: Oxford University Press, 1996.

Ozawa, Sh., Mongolyn Nuuts Tovchoony Ertönts (The World of the Secret History of the Mongols), Ulaanbaatar: Mongol Sudlal Press, 2002.

Patton, D., Badr Al-Din Lu'lu: Atabeg of Mosul, 1211-1259, Seattle and London: University of Washington Press, 1991.

Paviot, J., "England and the Mongols (C. 1260-1330)," JRAS 10.3 (2000): 305-18.

Peacock, A., "The Saljūq Campaign against the Crimea and the Expansionist Policy of the Early Reign of 'Ala' al-Dīn Kayqubād," JRAS, 3/16, 2 (2006): 113-49.

_. "Nomadic Society and the Saljūq Campaigns in Caucasia," Iran and the Caucasus 9.2 (2005): 205-30.

Pelliot, P., "Les Mongols et La Papauté," Revue de l'Orient Chrétien 23, 24, 28 (192223, 1924, 1931-32).

Perdue, P., China Marches West, London: Belknar Press, 2005.

Petoyan, V., "Sasuni T’oŕnikyan Ishkhanut'yuně," Teghekagir 2 (1955): 85-96.

Petrushevsky, I., "The Socio-Economic Condition of Iran Under the Îl-Khāns," in J.

A. Boyle (ed.), The Cambridge History of Iran. The Saljuq and Mongol Periods, vol.

5, Cambridge: Cambridge University Press, 1968, 483-537.

- Zemledelije i Agrarnyje Otnoshenija v Irane XIII-XIV vekov, Moscow-Leningrad: Academy of Sciences Press, 1960.

_. "K Istorii Sel'skogo poseleniya i sel'skoi obschiny v Irane v XIII-XV vv.," Uchenye Zapiski Instituta Vostokovedenija XVI (1958): 31-51.

Pfeiffer, J., "A Turgid History of the Mongol Empire in Persia," in J. Pfeiffer and M. Kropp (eds.), Theoretical Approaches to the Transmission and Edition of Oriental Manuscripts, Beirut: Ergon Verlag Würzburg in Kommission, 2007, 107-29. 
"Reflections on a 'Double Rapprochement': Conversion to Islam among the Mongol Elite during the Early Ilkhanate," in L. Komaroff (ed.), Beyond the Legacy of Genghis Khan, Leiden-Boston: Brill, 2006 a, 369-89.

- (ed.), History and Historiography of Post-Mongol Central Asia and the Middle East, Wiesbaden: Harrassowitz Verlag, 2006 b.

_. "Ahmad Tegüder's Second Letter to Qalā'ūn (682/1283)," in J. Pfeiffer and S. Quinn (eds.), History and Historiography of Post-Mongol Central Asia and the Middle East, Wiesbaden: Harrassowitz Verlag, 2006 c, 167-202.

- "Conversion Versions: Sultan Öljeitu's Conversion to Shil'ism (709/1309) in Muslim Narrative Sources," Mongolian Studies 22 (1999): 35-67.

Phillips, E., The Mongols, London: Thames and Hudson, 1969.

Pogossian, Z., "The Armenian Reaction to the Concept of the Primacy of the Roman Church in the Twelfth and Thirteenth Centuries," in O. Merisalo and P. Pahta (eds.), Frontiers in the Middle Ages, Paris: Louvain-la-Neuve, 2006, 259-90.

Poliak, A., "The Influence of Chingiz-Khān's Yāsa upon the General Organization of the Mamlūk State" BSOAS 10 (1942): 862-76.

Powicke, F., "The Compilation of the 'Cronica Majora' of Matthew Paris," Proceedings of the British Academy, XXIX (1944).

Purevdorj, D., Mongolyn Nuuts Tovchoony Tailbar (Comments on the Secret History of the Mongols), Ulaanabaatar: Tektonik Press, 2001.

Raby, J. and Fitzherbert, T. (eds.), The Court of the Il-Khans, 1290-1340. Oxford: Oxford University Press, 1996.

Rachewiltz, I. de, "The dating of the Secret History of the Mongols-A re-interpretation," Ural-Altaische Jahrbücher, 22 (2008): 150-84.

- (ed.), "A Note on the Word Börte in the Secret History of the Mongols," East Asian History 13, 14 (1997): 153-55.

. with H. L. Chan et al. (eds.), In the Service of the Khan: Eminent Personalities of the Early Mongol-Yüan Period (1200-1300), Asiatische Forsc hungen, vol 121, Wiesbaden, 1993.

_. "The title Činggis Qan/Qayan re-examined," in Walther Heissig and Klaus Sagaster (eds.), Gedanke und Wirkung: Festschrift zum 90. Geburtstag von Nikolaus Poppe, Wiesbaden, 1989, 281-98

_ . "Turks in China under the Mongols: A Preliminary Investigation of TurcoMongol Relations in the 13th and 14th Centuries," in Morris Rossabi (ed.), China among Equals, Berkeley: University of California Press, 1983, 281-310.

- Papal Envoys to the Great Khans, London: Faber and Faber, 1971.

Ratchnevsky, P., Genghis Khan, His Life and Legacy, T. N. Haining (tr. and ed.), Oxford: Blackwell, 1991.

Redgate, A., The Armenians, Oxford: Blackwell, 2000.

Remler, Ph., "New Light on Economic History from Ilkhanid Accounting Manuals," Studia Iranica, 14/2 (1985): 157-77.

Richard, Jean, La Papauté et les Missions d'Orient au Moyen Âge (XIIIe-XVe Siècles), Rome: Palais Farnése, École Française de Rome, 1998.

_ . 'D'Älğgigidäi à Ġazan; la continuité d'une politique franque chez les Mongols d'Iran', in D. Aigle (ed.), L'Iran à la Domination Mongole, Tehran: Institut Français de Recherche en Iran, 1997, 57-69.

- Croisades et Etats Latins d'Orient, Aldershot: Variorum Reprints, 1992. . "La letter du Connétable Smbat et les reapports entre Chrétiens et Mongols au milieu du XIIIème siècle," in D. Kouymjian (ed.), Armenian Studies/Études arméniennes: In Memoriam Haïg Berbérian, Lisbon: Calouste Gulbenkian Foundation, 1986, 683-696.

. Croisés, Missionnaires et Voyageurs, London: Variorum Reprints, 1983. 
. Les Relations entre l'Orient et l'Occident au Moyen Âge, London: Variorum Reprints, 1977.

- Orient et Occident au Moyen Âge: Contracts et Relations (XIIe-XVe s.), London: Variorum Reprints, 1976.

Roberg, B., Das Zweite Konzil von Lyon (1274), Paderborn: Ferdinand Schöning, 1990.

Rossabi, Morris, (ed.), China among Equals, Berkeley: University of California Press, 1983.

- Khubilai Khan; His Life and Times, Berkeley: University of California Press, 1988.

Rudt-Collenberg, W., The Rubenides, Het'umides and Lusignans, Paris: Librairie C. Klincksieck, 1963.

Runciman, S., A History of the Crusades, Vol. I. Cambridge: Cambridge University Press, 1951.

Russell, J., "The Formation of the Armenian Nation," in R. Hovannisian (ed.), The Armenian People from Ancient to Modern Times, vol.1, London: Macmillan, 1997, 19-36.

- Zoroastrianism in Armenia, Cambridge, MA: Harvard University Press, 1987.

Saishiyal, Chinggis Khan-nu Tobchiyan (The History of Chinggis Khan), vol. 1, Khokh Khot: Inner Mongolian People's Press, 1987.

Sanjian, A., "The Orbelians and Proshians of Siwnik': Patrons of Religious Institutions," Handes Amsorya (1987): 911-24.

Sasson, J. (ed.), Civilizations of the Ancient near East, 4 vols., vol. 2, New York: Simon and Schuster Macmillan, 1995.

Saunders, J., Muslims and Mongols, G.W. Rice (ed.), Christchurch: University of Canterbury, 1977.

The History of the Mongol Conquests, London: Routledge and Paul, 1971.

Savvides, A., Byzantium in the Near East: Its Relations with the Seljuk Sultanate of Rum in Asia Minor, the Armenians of Cilicia and the Mongols AD c. 1192-1237, Thessalonikē: Kentron Byzantinon Epeynon, 1981.

Scherbak, A., Rannije Turko-Mongol'skije yazykovyje svjazi, VIII-XIV vv. (Early Turco-Mongol Linguistic Connections), St. Petersburg: ILI RAN, 1997.

Schurmann, H., "Mongolian Tributary Practices of the Thirteenth Century," HJAS 19.3/4 (1956): 304-89.

Seaman, G. (ed.), Foundations of Empire: Archaeology and Art of the Eurasian Steppes, vol. 3, Los Angeles: Ethnographics Press, University of Southern California, 1989.

Sechin J. and Hyer, P., Mongolia's Culture and Society, Boulder, Colorado: Westview Press, 1979.

Setton, K. (ed.), A History of the Crusades. The Later Crusades 1189-1311, vol. 2, Philadelphia: University of Pennsylvania Press, 1962.

Shagdar, Kh., Güyüg Khaan, N. Dugarsuren (ed.), Ulaanbaatar: Khaadyn San, 2000.

Shaw, M., "Introduction" in Chronicles of the Crusades, Harmondsworth: Penguin, 1963, 5-9.

Shiraiwa, K., "Īnjū in the Jāmi' al-Tavārīkh of Rashīd al-Dīn," AOASH XLII/ 2-3 (1988): 371-76.

Shirendyb, B., Natsagdorj, Sh. and Perlee, X. (eds.), Bugd Nairamdah Mongol Ard Ulsyn Tüükh (The History of the Mongolian People's Republic), Ulaanbaatar: Academy of Sciences Press, 1966.

Sinclair, T., "The Economy of Armenia under the Il-Khans," JSAS 11 (2000): 39-52.

Sinor, D.(ed.), The Cambridge History of Early Inner Asia, Cambridge: Cambridge University Press, 1990. 
Smith, J. (Jr.), "Demographic Considerations in Mongol Siege Warfare," Archivum Ottomanicum 13 (1993-1994): 329-34.

__. “Ayn Jālut: Mamlūk Success or Mongol Failure?," HJAS 44, no. 2 (1984 a): 307-45.

_ .Mongol Campaign Rations: Milk, Marmots, and Blood?," JTS 8 (1984 b): 223-28.

_. "Mongol Manpower and Persian Population," JESHO 18 (1975): 270-99.

—. "Mongol and Nomadic Taxation," HJAS 30 (1970): 46-85.

Sneath, D. (ed.), Imperial Statecraft: Political Forms and Techniques of Governance in Inner Asia, Sixth-Twentieth Centuries, Bellingham: Mongolia and Inner Asian Studies Unit, University of Cambridge, 2006.

Somogyi, J. de, "A Qașīda on the Destruction of Baghdād by the Mongols," BSOAS 7 (1933-35): 41-48.

Soucek, P., "Armenian and Islamic Manuscript Printing: A visual Dialogue," in T. Mathews and R. Wieck (eds.), Treasures in Heaven, Armenian Art, Religion and Society, New York: The Pierpont Morgan Library, 1998, 115-131.

Spuler, B., History of the Mongols: Based on Eastern and Western Accounts of the Thirteenth and Fourteenth Centuries, New York: Dorset Press, 1972.

- The Mongols in History, London: Pall Mall Press, 1971.

. Die Mongolen in Iran: Politik, Verwaltung und Kultur der Ilchanzeit 12201350, Academie-Verlag, Berlin: 1968.

- The Muslim World, The Mongol Period, C. Bagley and F. Ronald (tr.), vol. 2, Leiden: E. J. Brill, 1960.

- Die Golden Horde. Die Mongolen in Russland, Leipzig: O. Harrassowitz, 1943.

Stewart, A., "The Assassination of King Het'um: The Conversion of Ilkhans and the Armenians," JRAS, 3/15, 1 (2005): 45-61.

. The Armenian Kingdom and the Mamluks: War and Diplomacy during the Reigns of Het'um II (1289-1307), Leiden: Brill, 2001.

Stone, M., Kouymian, D. and Lehmann, H., Album of Armenian Paleography, Copenhagen: Aarhus University Press, 2002.

Le Strange, G. (tr.), Palestine under the Moslems, London: Alexander P. Watt, 1890.

Strayer, J. (ed.), Dictionary of the Middle Ages, vol. 3, New York: Charles Scribner \& Sons, 1983.

Sykes, P., A History of Persia, vol. 2, London: Macmillan, 1951.

Syme, R., Anatolica, Oxford: Clarendon Press, 1995.

Ter-Ghewondyan, A., Armenija i Arabskii Khalifat (Armenia and Arabic Caliphate), Erevan: Academy of Sciences Press, 1977.

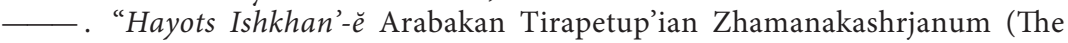
Armenian Ishkhan in the Period of Arab Domination)," Patma-Banasirakan Handes 2 (1964): 121-34.

- (ed.), Teghekagir (Information), Erevan: Academy of Sciences Press, 1955.

Thompson, E., The Huns, P. Heather (revised), Oxford: Blackwell Publishers, 1996.

Thomson, R., "Supplement to A Bibliography of Classical Armenian Literature to 1500 AD: Publications 1993-2005," Le Muséon 120 (1-2) 2007: 163-223.

_. "The Crusaders through Armenian Eyes," in A. Laiou and R. Mottahedeh (ed.), The Crusades from the Perspective of Byzantium and the Muslim World, Washington D.C.: Dumbarton Oaks Research Library and Collection, 2001.

_. "Armenian Christianity," in P. Ken, et al., The Blackwell Dictionary of Eastern Christianity, Oxford: Blackwell, 1999.

- "Armenian Literary Culture through the Eleventh Century," in R. Hovannisian (ed.), The Armenian People from Ancient to Modern Times, vol. 1, London: Macmillan Press, 1997, 199-239. 
A Bibliography of Classical Armenian Literature to 1500 AD, Turnholt: Brepols, 1995.

-. Studies in Armenian Literature and Christianity, Aldershot: Variorum, 1994.

Thorau, Peter, The Lion of Egypt; Sultan Baybars I and the Near East in the Thirteenth Century, P.M. Holt (tr.), London and New York: Longman, 1992.

Tikhonov, D., "Nalogi i nalogovyje terminy v Uigurskom gosudarstve" (Taxes and Tax Terms in Uigur State), Uchjenyje Zapiski Instituta Vostokovedenija 16 (1958): 52-77.

Tikhvinskii, S. and Sandag, Sh. (eds.), Mongol-Tataruud Azi Evropt (The MongolTatars in Asia and Europe), Ulaanbaatar: State Press, 1984.

Togan, Z.(tr.), Leiser, G., "References to Economic and Cultural Life in Anatolia in the Letters of Rashīd al-Dīn," in J. Pfeiffer and S. Quinn (ed.), History and Historiography of Post-Mongol Central Asia and the Middle East, Wiesbaden: Harrassowitz Verlag, 2006, 84-111.

Toumanoff, C., "Armenia and Georgia," in J.M. Hussey (ed.), The Cambridge Medieval History, vol. 4, part 1, Cambridge: Cambridge University Press, 1966, 593-637.

- Studies in Christian Caucasian History, Georgetown: Georgetown University Press, 1963.

Trepavlov, V. (ed.), Posol'skaja kniga po svjazjam Rossii s Nogaiskoi Ordoi (1576), Moscow: Russian Academy of Sciences, 2003.

—. Istorija Nogaiskoi Ordy, Moscow: Vostochnaja Literatura, 2002.

_. Gosudarstvennyi stroi Mongol'skoi Imperii XIII veka, Moscow: Vostochnaja Literatura, 1993.

Tserenbaltav, S. and Minjin, Ts., Temüjin-Chinggis Khany 'Ikh Zasag' Huul' (The Great Yasa of Temüjin-Chinggis Khan), Ulaanbaatar: Artsoft, 2006.

Tseveendorj, D., "Prehistoric Period," in D. Tseveendorj (ed.), The History of Mongolia, vol. 1, Ulaanbaatar: Admon, 2003, 57-109.

Tsevel, Ya, Mongol Khelnii Tovch Tailbar Tol' (Explanatory Dictionary of Mongolian Language), Kh. Luvsanbaldan (ed.), Ulaanbaatar: State Publishing Committee, 1966.

Tumanyan, F., "Oratsutsayin Hashvumnerum Hachakh Katorvogh Yerku Skhali masin (About Two Mistakes that often occur in Calendar Calculations)," Lraber 4 (1973): 79-81.

Tumurtogoo, D. (ed.), Arab Üsegnii Mongol Durskhalyn Sudalgaa (The Mongolian Monuments in Arabic Script), 3 vols., vol. 3, Ulaanbaatar: The International Association for Mongol Studies, 2002.

- (ed.), Mongol Dörvöljin Üsegiin Duraskhalyn Sudalgaa (The Mongolian Monuments in 'Phags-Pa Script), 2 vols., vol. 2, Ulaanbaatar: The International Association for Mongol Studies, 2002.

Turnbull, S., The Mongols, Men at Arms, London: Osprey Publishing Ltd, 1980.

T'urshyan, H., "Shah-i-Armenner (Shahi-Armenians)," Patma-Banasirakan Handes 4 (1964): 117-34.

Uspenskii, F., Istorija Vizantiiskoi Imperii (History of Byzantine Empire), Moscow: Academy of Sciences Press, 1948.

Vásáry, István, Cumans and Tatars; Oriental Military in the Pre-Ottoman Balkans, 1185-1365, Cambridge: Cambridge University Press, 2005.

_ . "Cuman Warriors in the Fight of Byzantium with the Latins," AOASH 57 /3, (2004): 263-270.

- " "History and Legend' in Berke Khan's Conversion to Islam," Aspects of Altaic Civilization, Denis Sinor (ed.), Bloomington: Indiana University, 1990, 230-52. 
"The Origin of the Institution of Basqaqs," AOASH 32 /2, (1978): 201-206.

Vernadsky, G., Mongoly i Rus' (The Mongols and Rus'), Moscow: Agraf, 2001.

- The Mongols and Russia, New Haven: Yale University Press, 1953. 60.

. "The Scope and Contents of Chingis Khan's Yasa," HJAS 3, 3/4 (1938): 337-

Vladimirtsov, B., Obschestvennyi stroi Mongolov, Mongol'skii kochevoi feodalizm (The Social System of the Mongols, Mongolian Nomadic Feudalism), Leningrad: Academy of Sciences Press, 1934.

Voegelin, E., "The Mongol Orders of Submission to European Powers, 1245-1255," Byzantion 15 (1940-41): 378-413.

Wang Min-hsin, "On 'Darqan'," The Third East Asian Altaistic Conference, Ch'en Chieh-hsien and Jagchid Sechin (eds.), Taipei, 1969, 234-36.

Weatherford, J., Genghis Khan and the Making of the Modern World, New York: Three Rivers Press, 2004.

Willey, P., The Castles of the Assassins, London: George G. Harrap, 1963.

Yingsheng, L., "War and Peace between the Yuan Dynasty and the Chaghadaid Khanate (1312-1323)," in R. Amitai and M. Biran (eds.), Mongols, Turks and others: Eurasian Nomads and the Sedentary World, Leiden: Brill, 2005, 339-358.

Yudin, V. (ed.), Utemish Khaji, Chingiz-Name, Alma-Ata: Academy of Sciences Press, 1992.

Zakirov, S., Diplomaticheskije otnoshenija Zolotoi Ordy s Egiptom (Diplomatic Relations between the Golden Horde and Egypt), Moscow: Nauka, 1966. 


\section{INDEX}

Abaqa 13, 15, 27, 28, 78, 93, 96, 125, 135, $154,155,156,160,161,163,164,165$, $166,167,168,169,172,173,174,175$, $176,177,180,187,189,190,193,194$, 221,224

'Abbasid 39, 141, 220

'Abbāsid Caliph 127, 131

Abu'l-Fidā' 29, 185, 186, 199, 209, 211, 212, 213, 216

Abulistān 170

Abū Sa'ìd 26, 116

Acre 145, 172, 173, 174, 183, 185, 186

Afghanistan 28, 39, 42, 127, 135, 151

Aghbugha 57, 61, 74

'Alā al-Dīn Muhammad 123

Alamut 83, 122, 123

al-Ashraf Khalīl 185, 189

Ala-Tagh 137, 160, 170, 176

Albanians 56, 82

Aleppo 62, 65, 83, 133, 136, 137, 138, $139,140,142,143,147,148,164,165$, $174,187,203$

Alfonso III 188

Alinaq 174, 178, 179, 210

al-Kāmil Muḥammad 73, 133, 135

alliance $24,36,66,71,83,84,86,89,140$, $142,145,152,154,157,163,171,173$, $177,179,182,194,198,207,217,221$, 224, 225

al-Maqrīzī 29, 200, 211

al-Mughīth 'Umar 136, 142

al-Nāșir Yūsuf 136, 139, 140

al-Nāṣir Muhammad 188, 207, 208, 212, 225

Alp Arslan 36

al-Sacid Hasan 142

Altai Mountain 37

altamgha 95

Altan Debter 8, 9, 10, 27

Altan Ordyn Ulus 39

Altuna 52, 66, 95

Amanus Mountains 34, 162

Amaury Lusignan 188

Amida 53, 63, 133, 137

Anatolia 1, 32, 64, 65, 66, 67, 91, 114, $122,129,137,170,178,179,182,188$, $195,207,213$ anda 41

Angurag 64, 91, 95

Ani 12, 26, 33, 51, 58, 59, 60, 67, 73, 102, $112,114,116,117,166,205,215$

Antioch 36, 79, 89, 137, 138, 140, 145, $148,155,163,169,172$

Anti-Taurus Mountains 34

Arabic 2, 20, 29, 35, 46, 60, 115, 173, 177, 185, 186, 198, 200, 203, 206, 223

Arghun 13, 17, 19, 24, 25, 27, 28, 75, 76, $78,82,92,105,106,108,109,111$, $137,153,160,168,176,177,178,179$, $180,181,182,183,184,187,190,197$, 202, 224

Armenia 1, 3, 4, 11, 13, 14, 15, 16, 17, 19, $26,28,30,31,32,33,35,36,42,43$, $44,46,48,50,51,52,53,54,55,60$, $63,64,65,66,67,69,72,73,75,78$, $79,80,81,92,93,95,99,100,101$, $102,103,106,107,108,109,110,111$, $112,113,114,117,118,119,120,122$, $124,126,127,130,138,150,151,160$, $162,166,169,181,184,185,189,191$, $199,203,207,210,218,219,222,223$, 224

Armenian 1, 2, 3, 4, 5, 6, 10, 12, 13, 14, $15,16,17,18,19,20,21,22,23,24$, $25,26,27,28,29,30,31,32,33,34$, $35,43,44,45,46,48,51,52,53,54$, $55,56,58,59,60,61,62,64,65,67$, $68,69,71,72,73,74,75,78,79,80$, $81,82,84,85,86,87,88,89,90,91$, $92,93,94,95,96,97,99,102,105$, $106,107,108,109,111,112,114,115$, $116,117,119,120,121,122,125,127$, $129,130,133,134,135,136,137,139$, $140,141,143,144,146,148,149,150$, $153,155,156,157,159,160,161,162$, $164,165,166,167,168,169,172,173$, $174,175,176,177,178,179,180,181$, $182,183,184,185,186,187,189,190$, $193,194,197,198,199,200,201,202$, 203, 204, 205, 206, 207, 208, 209, 212, $213,214,215,216,217,219,220,221$, 222, 223, 224, 225

Armenian Houses 4, 5, 93 
Armenian Kingdom of Cilicia 1, 5, 20, $35,60,79,82,96,148,207,224$

Armenians 1, 2, 3, 5, 6, 11, 14, 16, 19, 20, $22,24,25,28,29,30,31,32,34,35$, $36,43,45,49,50,55,64,65,68,71$, $73,74,84,87,88,89,90,93,94,96$, $97,99,102,108,113,118,120,121$, $122,126,127,137,138,140,141,143$, $145,146,148,149,153,155,156,159$, $160,161,162,164,165,167,169,170$, $171,173,174,176,178,180,181,183$, $186,187,188,189,190,193,197,198$, 199, 200, 203, 205, 208, 209, 212, 213, $214,216,217,218,219,220,221,223$, 224

Armenian sources 4, 6, 11, 14, 15, 24, 29, $44,48,54,55,64,84,86,99,108,120$, $134,138,151,160,201,208,209,220$

Arran 48, 49, 50, 60, 67, 101, 102, 125, $150,151,160,184,209,216,223$

Arrān 150

Artsakh 34, 58

Artsrunids 34, 43, 78, 90, 103, 166

Ashraf Mūsā 136, 139, 142, 146, 147

Asia Minor 32, 33, 35, 36, 39, 61, 63, 73, $79,96,121,219,220,223$

Aslan 59, 75

atabeg $34,49,59,77,78,129,135,144$, 166,181

Awag 12, 34, 56, 58, 61, 63, 67, 72, 73, 74, $76,77,82,85,90,91,92,94,95,96$, $122,166,221$

Ayas

Lajazzo 36, 161, 162, 182, 198, 212, 217

'Ayn Jālūt 146, 147, 156

Ayyubids 43, 63, 136, 147

azats 89

Azerbaijan 31, 49, 50, 51, 53, 59, 60, 61, $63,83,101,102,118,125,132,133$, $135,136,149,151,152,155,171,210$, 218,223

Baarin 58

Badr al-Dīn Lu'lu' 129, 133, 134, 136, 137

Baghdad 13, 39, 52, 55, 60, 64, 83, 87, $112,121,122,126,127,128,129,130$, $132,133,137,142,152,153,154,157$, $160,165,166,181,183,184,187,194$, $196,197,213,215,216,218$

Bagratid dynasty 43, 90

\section{Bagratuni 135}

Baidu 160, 184, 188, 189, 194, 197

Baiju 12, 13, 17, 60, 61, 62, 63, 64, 65, 66, $67,73,74,76,77,79,80,85,91,94$, $95,122,126,127,129,131,137,171$

baj 114

Baraq 167, 168

Bar Hebraeus 5, 30, 79, 81, 83, 126, 127 , $130,138,139,142,155,170,176,185$, 189,197

basqaq 103, 105, 106, 107, 210

Batu 21, 39, 65, 76, 81, 84, 85, 88, 90, 93, $94,101,104,124,144,150,151,153$, 154

Baybars 140, 144, 147, 149, 152, 154, 160, $161,162,163,164,165,169,170,172$, $173,184,187,224$

Berke 13, 150, 151, 152, 153, 154, 155, $156,157,163,167$

Besuts 38

Bilarghun 206

Bitikchis 109

Bjni 34, 75

Bohemond VI 89, 137, 138, 139

Bolad Chinksank 26

Borjigin 8, 38

Börte 39

Bugha 27, 58, 94, 179, 180

Buqa 105, 108, 124, 128, 129, 132, 136, $139,144,145,146,147,148,166,181$

Būyids 129

Byzantium 5, 34, 163, 198, 224

Caesarea 63, 66, 80, 90, 94, 103, 160, 170, 198

Cairo 126, 144, 147, 152, 164, 172, 182, 188,211

Carpini 30, 81, 83, 85

Caspian Sea 46

Catholicos 14, 15, 17, 36, 92, 95, 137, $186,187,205,212,215$

Caucasian Albania 11, 45, 48, 94, 95, 127

Caucasus 1, 4, 18, 19, 27, 32, 39, 43, 44, $46,50,52,53,55,67,71,76,86,90$, $93,95,96,100,101,107,110,115$, $121,122,127,135,149,151,153,154$, $167,168,171,191,194,210,214,216$, $219,221,223$

Čayan Teüke 9, 10

census 13, 19, 25, 99, 103, 105, 107, 108, $109,110,111,115,118,119,208,220$

Central Asia 20, 22, 37, 39, 42, 43, 49, 67, $83,85,100,150,159,195,220$ 
Chaghatai 39, 51, 57, 64, 68, 91, 122, 124 , $125,129,134,150,153,167,168,172$, 210

Chaghataid 152, 153, 189, 204

Chaghatai Ulus 39, 125, 167, 168, 210

Chin Empire 41

Chinese 7, 9, 10, 22, 28, 30, 37, 40, 42, $100,104,106,108,180,184$

Chinggisids 27, 51, 81, 124, 143, 149, $150,152,153,160,166,167,171,191$, $204,218,223$

Chinggis Khan 7, 8, 9, 16, 22, 27, 28, 38, $39,40,41,42,45,46,47,50,51,52$, $53,55,64,74,80,81,100,101,104$, $121,124,125,128,150,151,222$

Choban 204, 209, 210, 211, 213, 215, 216

Chormaghan 19, 45, 50, 51, 52, 53, 54, $55,56,58,60,64,66,67,72,73,76$, $93,94,96,101,102,103,104,122$, $128,166,168,180,221$

Christianity 24, 80, 83, 87, 90, 95, 155 , 196, 213, 219

Cilician Armenia 5, 11, 16, 18, 24, 26, 31, $34,35,36,62,65,79,80,83,84,92$, $96,99,119,120,148,149,159,160$, $161,162,169,179,182,184,185,186$, $187,193,195,198,202,203,205,208$, $209,212,213,217,220,224$

Cilician Armenians 2, 31, 143, 149, 157, $159,160,175,181,190,219,220,221$ clan obog 38, 41, 100, 143, 216

Clement IV 162, 172

Clement V 21, 205, 206

conquest $2,10,18,28,33,39,44,46,52$, $53,56,60,66,68,73,75,101,107$, $110,128,130,132,133,137,142,147$, $153,157,165,189,196,201,204,213$, 222, 224

Constantinople 36, 147, 163, 198

Council of Lyons 173

Crusaders 5, 35, 49, 141, 224

Crusades 5, 20, 22, 34, 84

cultural transmission 3

Cyprus 21, 36, 79, 82, 83, 172, 182, 188, 189, 194, 201, 207, 209, 212, 216, 217

Damascus 29, 136, 137, 138, 139, 140, $143,144,148,173,178,187,199,200$ darughachi 99, 100, 103, 104, 105, 107 davāt-dār 129
David Narin 90, 153

David of Ashby 172, 173

David Ulu 90, 137, 153, 180

davtars 109

decimal system $23,41,45$

Demetrē 33, 78, 94, 108, 174, 179, 180

Derbent 45, 50, 85, 94, 149, 167, 174, $179,180,210$

Dhail ta'rīkh Dimashq 29

divans 109

Dopians 34

Doquz 15, 121, 130, 142, 155

Dwin 34, 75

Dzungaria 38

Edessa 20, 36, 55, 63, 133, 137, 186, 214

Edward I 170, 172, 173, 183, 185, 186, $195,199,206$

Egypt 49, 79, 94, 122, 124, 126, 132, 133, $136,137,140,141,142,144,145,146$, $148,149,152,153,154,156,157,161$, $162,163,165,169,172,174,177,182$, $185,187,188,194$

elchis $75,113,115$

Elikum 59, 75, 181

Erevan 19, 26, 34

Erznka 19, 61, 63, 64, 65, 103, 163, 174

Erzurum 12, 60, 61, 103, 114, 208

Euphrosyne Palaeologina 155, 163

Fars 53, 120, 125

fortress $11,45,48,56,57,58,59,72,74$, $89,94,133,139,140,162,186,187$, 212

Frik 25, 108, 180

Gandzak 12, 14, 19, 48, 51, 53, 54, 60, 125

Gandzasar 26, 76

Gaza 145, 174

Geghark'unik' 75, 210

GegharkGuniku 34, 56, 60, 72

Geikhatu 17, 160, 179, 184, 185, 187, 188, 189,197

Georgia 11, 12, 13, 18, 28, 31, 33, 46, 48, $49,50,53,54,56,63,65,66,67,76$, $78,83,90,92,101,102,107,108,112$, $116,118,122,125,127,130,137,150$, $151,166,167,168,178,180,181,197$, $210,218,223$

Georgians 1, 3, 12, 13, 28, 48, 49, 50, 51, $56,76,90,91,102,146,174,178,180$ 
Ghatagha 58

Ghazan 18, 19, 26, 114, 115, 118, 138, $157,160,179,181,184,188,193,194$, $195,196,197,198,199,200,201,202$, 203, 217, 223, 224

Ghiyāth al-Dīn Kay Khusraw II 59, 60

Gìlān 204, 209

Gobi desert 37

Golden Horde 13, 39, 68, 76, 81, 84, 85, $101,118,129,141,143,149,150,151$, $153,154,155,156,157,159,163,166$, $167,168,171,174,179,180,181,188$, $189,190,196,198,204,210,216,218$, 223

Gontsa 76, 77, 92, 166

Greater Armenia 1, 2, 3, 4, 11, 12, 14, 15, $16,18,24,26,28,29,31,40,43,50$, $55,60,64,65,66,67,68,69,71,77$, $78,79,85,89,90,92,93,94,95,96$, $99,100,102,103,106,107,108,110$, $111,113,114,119,120,126,141,143$, $149,153,160,161,166,173,175,179$, $181,183,186,189,191,197,202,205$, $208,209,210,213,214,217,218,219$, $220,222,223$

Great Mongol Empire 1

Gregory X 173

Grigor Aknerts'i 1, 11, 15, 16, 17, 27, 44, $45,49,50,52,53,54,56,60,62,64$, $67,68,77,80,81,84,85,90,91,94$, $102,103,105,108,109,110,111,112$, $113,117,119,127,131,134,135,136$, $137,139,160,161,162,165,168,169$

Güyük $64,65,74,80,81,82,83,88,90$, $93,94,96,104,122,123,154,171,221$

Hamā 136, 139, 147

Hamadān 46, 48, 53, 129, 132, 144, 150, 175

Hamd Allāh Mustawfī Qazvīnī 29, 99

Hārim 139

Hasan Jalal 58, 74, 75, 76, 82, 85, 93, 94, $96,116,151,153,221$

Hasan-Jalalians 34

Hawak'umn Patmut'ean 14

Hayton 4, 5, 21, 85, 86, 200

Henry I 21, 82

Herat 121, 125, 168, 198, 213

Het'um I. See King Het'um

Het'umids 21, 34, 36, 207

Het'um II 24, 162, 172, 175, 182, 183 , $184,185,186,187,188,193,194,195$, 198, 201, 205, 206, 207, 217, 224
Het'um Patmich' 4, 11, 21, 23, 24, 27, 62, $84,85,86,87,88,125,133,140,148$, $162,165,169,170,174,175,176,178$, $185,198,199,202,203,224$

History of Mar Yaballaha III 30

Holy Land 2, 22, 24, 87, 88, 132, 133 , $136,137,140,148,157,171,183,186$, $189,190,195,201,206,214,221,224$

Homṣ 136, 139, 142, 146, 147, 174, 175, 199

\section{Honorius IV 182}

Hŕomklay 17, 25, 35, 36, 186, 187

Hsi-Hsia Tangqut kingdom 41

Hugh III 182, 209

Hủlegủ $13,15,19,24,27,28,60,69,77$, $78,82,88,92,93,95,96,103,110$, $111,112,113,114,121,122,124,125$, $126,127,128,129,130,131,132,133$, $135,136,137,138,139,140,141,142$, $143,144,145,146,147,148,149,150$, $151,152,153,154,155,156,157,159$, $160,163,164,165,166,167,171,175$, $179,188,200,220,221,222$

Ibn al-Athīr 29, 43, 45, 46, 48, 49, 50, 51 Ibn al-Qalānisī 29

Il-Khanate 2, 29, 39, 51, 69, 76, 91, 93, $106,110,114,116,118,120,121,127$, $149,152,154,157,159,163,167,168$, $171,175,184,189,190,191,193,194$, $195,198,203,204,209,210,211,213$, $214,215,217,218,225$

Iran 9, 22, 26, 27, 29, 32, 39, 41, 46, 51, $52,53,63,64,65,66,67,69,76,86$, $93,108,110,112,114,115,118,120$, $121,122,124,125,126,127,128,135$, $141,142,148,150,151,156,157,160$, $167,177,178,194,195,197,202,204$, $210,211,218,223$

Iraq $39,53,83,125,128,133,135,136$, $137,151,157$

Irenjin 210

ishkhans $43,67,102,106$

Islam $27,35,60,122,123,125,126,127$, $152,159,176,189,193,195,196,203$, $217,219,222$

Ismā'ìlī 121, 123, 125, 126, 128, 131, 132, $141,168,220$

Ismā'ìlīs $64,113,121,122,123,124,125$, $126,141,153$

Itughata 56

Iwanē $33,34,49,56,57,58,72,75$ 
Jalāl al-Dīn 28, 29, 44, 46, 51, 52, 53, 54, $55,123,144$

Jalayirid 218

Jalayirs 38

James I 172

James II 188

Jāmic al-Tawarīkh 10, 26, 27, 45, 46

Japan 40, 147

Jebe $24,42,45,46,47,48,49,50,52,58$, 60,72

Jerusalem 14, 16, 140, 145, 154, 157, 172, $173,194,200,201,203,214,224$

Jochi 39, 51, 65, 68, 101, 124, 129, 141, $150,151,152,167$

Jochids 149, 151, 152, 153

Jujan 37

Justinian II

Byzantine Emperor 35

Juvaynī 28, 29, 45, 48, 52, 53, 55, 58, 78, $82,101,104,105,108,112,113,115$, $123,124,125,126,130,166,177$

Jūzjānī 28, 73, 123, 131, 132, 133, 134, 135,152

Karin 12, 18, 60, 61, 103, 117

Kars 51, 58, 60, 64, 67, 78, 85, 102, 114

K'art'lis Chovreba 30

Kayen 14, 56, 60, 72, 75

Keraits 38

Ket-Buqa 124, 128, 139, 144, 146

Khachen 12, 58, 60, 72, 74, 75, 93, 151

Khaghbakians 34, 93

khal 112

kharaj 112, 117, 208

Kherulen 37

kheshig (kesig) 41

Khingans 37

Khlat 49, 51, 53, 55, 63, 103

Khoshak 77, 78, 166

khuda (quda) 41

Khuiten 47

Khurasan 42, 53, 83, 100, 112, 121, 123, $125,168,179,181,184,197,209$

Khuzistan 51

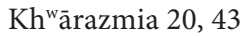

Khwārazm-Shāh 29, 41, 43, 44, 45, 46, 51, $53,54,144$

Kidans 7, 38

King David 49, 68, 77, 91, 92, 108, 121, $127,137,153,155,169,197$

King Het'um 20, 24, 62, 65, 79, 80, 81, $84,85,86,88,89,92,94,121,125$,
$133,136,137,138,139,140,141,148$, $155,160,161,162,169,172,174,175$, $185,187,188,194,198,199,200,201$, 205, 209, 221

Kirakos Gandzakets'i 4, 11, 12, 14, 15, 16, $18,19,24,27,33,35,44,45,46,47$, $48,49,50,51,52,53,54,55,56,57$, $58,59,60,61,62,63,64,65,66,68$, $72,73,74,75,76,79,82,84,85,86$, $87,88,90,91,92,94,95,102,103$, $105,106,108,109,110,111,113,114$, $115,116,117,119,122,125,126,127$, $130,131,133,134,135,137,139,140$, $142,144,146,151,153,154,155,163$, $167,221,222$

Kitāb al-Mukhtașar 29

Korea 1, 40, 66, 83

Korikos 21, 36, 170, 215, 216

Köse Dagh 61, 62, 63, 67, 76, 79, 122

Kostandin of Lambron 36

Kotman 44, 45, 48, 49, 53

Kūhistān 123, 124, 125

Kyrkyzs 38

Lachin al-Manșūr 198

La Flor des Estoires de la Terre d'Orient 21,22

Lasha 49, 90, 94, 103, 108

Lewon II

Leo I 36

Lewon III 17, 24, 169, 170, 174, 179, 181, $182,184,190,224$

Lewon IV 202, 205, 207

Lewon V 208, 215, 216

Liao Shih 7, 30

Liparit 59, 197

Loŕi

Lori 12, 33, 51, 57, 135

Louis IX 65, 83, 130, 146, 171, 172

mal 115, 117, 205

Mamluks 5, 16, 18, 19, 29, 92, 141, 143, $145,146,148,149,150,153,154,156$, $157,159,160,161,162,163,165,166$, $169,172,173,175,177,178,180,182$, $183,185,186,190,198,199,200,201$, 203, 205, 206, 207, 209, 211, 212, 213, $217,220,224$

Mamluk Sultanate 2, 157, 188, 190, 208

Manazkert 51

Manchuria 7, 38

Manichaeism 38 
Maragha 48, 51, 131, 133, 135, 138, 197

Marash 36, 148, 170

Marbo 10

Marco Polo 21, 23, 30, 131, 161

Maria Despina Palaeologina 163, 189

Matheos Urhayets'i 10

Mayyāfāriqīn 27, 73, 133, 134, 135

Merkits 38

Mesopotamia 31, 121, 132, 133, 141, 144, $155,156,175,186$

Michael VIII 155, 162, 163, 190

Middle East 2, 18, 20, 21, 22, 31, 32, 39, $42,52,93,118,120,121,128,141$, $149,157,175,195,221$

Mkhit'ar Anets'i 10

Mkhit'ar Ayrivanets'i 10, 24, 44, 46, 53, $56,92,122$

Molar 11, 57, 67, 94

Möngke 24, 76, 77, 81, 86, 87, 88, 93, 95 , $96,99,109,111,119,121,122,123$, $124,125,127,143,150,152,153,154$, $156,167,173,174,175,196,221$

Mongol administration 2, 29, 103, 106, 120

Mongol-Armenian relations 4, 11, 13, 78, 97,175

Mongol-Armenian relationship 2, 6, 20, 22, 206, 217

Mongol conquest 1, 3, 9, 19, 28, 31, 36, $43,44,46,64,71,86,93,110,120$, $122,133,141,144,159,220,221,223$

Mongol Empire 1, 2, 3, 6, 8, 38, 67, 78, $79,82,83,85,89,99,100,101,107$, $109,110,111,113,118,121,128,132$, $143,147,156,159,167,171,189,203$, $214,219,220,222,223$

Mongol governors 3, 59, 71, 82, 93, 107, $197,219,222$

Mongolian 6, 8, 9, 10, 12, 16, 23, 37, 38, $72,75,100,101,103,105,111,112$, $113,116,117,154,184,196$

Mongols 1, 2, 3, 4, 5, 6, 7, 8, 9, 10, 11, 12, $13,14,15,16,17,18,20,21,22,23$, $24,25,26,27,28,29,31,34,37,38$, $39,40,41,43,44,45,46,48,49,50$, $51,52,53,54,55,56,57,58,59,60$, $61,62,63,65,66,67,68,71,72,73$, $74,75,76,77,78,79,80,81,84,86$, $87,88,89,90,91,92,93,94,95,96$, $97,99,100,102,103,104,106,107$, $109,110,111,114,115,118,119,120$, $122,123,124,127,128,129,130,132$,
$133,135,136,137,140,142,143,144$, $145,146,147,148,149,152,153,154$, $156,159,160,161,162,163,164,165$, $167,169,171,172,173,174,176,182$, $183,186,189,190,193,194,195,196$, 197, 198, 199, 200, 202, 205, 207, 209, $211,214,217,218,219,220,221,222$, 223,224

Mosul 65, 83, 129, 134, 135, 136, 142, 175,197

Mughan 45, 46, 53, 56, 60, 61, 67, 95, $102,108,126,180,209,223$

Muslim sources 26, 45, 48, 59, 64, 116, $121,130,204,207$

Musta'șim 128, 129, 131

Naimans

Naiman 38, 40, 47, 124

Nakhichevan 34, 48, 51, 63, 194, 197, 202

Nașīr al-Dīn al-Ṭūsī 123

Nation of Archers 1

Nawruz 179, 181, 194, 195, 197, 198, 202

Near East 1, 2, 143, 156, 159, 202

nemeri 116, 118

Nersēs 16, 25, 82, 95, 186, 187, 198, 199, 200, 201, 202, 205, 206, 212

Nersēs Palients' 25, 186, 187, 198, 199, 200, 201, 202, 206, 212

Nestorian Christianity 38

Nicholas IV 183, 186

nöker 41

nomads $2,3,8,23,102,115,147,151$, 196

noyans

noyan $55,56,60,64,65,67,68,69$, $88,101,102,109,111,127,132$, $150,151,184,195,219,221,223$

Nuzhat al- Qulūb 29

Ögedei 9, 50, 51, 52, 53, 60, 74, 100, 101, $104,106,112,115,167$

Oirat 106, 197

Oirats 38

Öljeitű 160, 193, 203, 204, 205, 206, 207, 208, 211

Onggirats 38

Onguts 38

Onon 7, 37, 47, 100

Orbelians 17, 34, 59, 90, 92

ordu $86,132,167,179$

Orkhon 7, 37, 38

Orkhon script 7, 38 
Oshin 35, 207, 208, 209, 215, 216

Öteged 51

paiza $82,86,107,133$

Palestine 22, 132, 133, 140, 141, 142, 145 , 146, 147, 171, 172, 183, 224

Patmut' iwn Hayots' 11,13

Patmut'iwn Nahangin Sisakan 17

Persian 2, 4, 11, 20, 26, 28, 29, 36, 54, 55, $60,83,105,106,112,114,116,125$, $127,128,134,137,142,144,181,196$, 204

Pervāne 169, 170

Philippe le Bel 183

Pope 21, 49, 63, 83, 145, 159, 162, 164, $171,172,173,182,186,194,198,205$, 206, 207, 212, 213, 214, 224

Prester John 49, 68, 159

primary sources $2,4,5,6,11,58$

Pŕoshians 92, 141

Pŕosh Khaghbakian 89, 92, 129, 130, 134, 141

qalan $80,111,112,115,116,117,118$

Qalāwūn 173, 177, 178, 179, 181, 182, $184,199,224$

Qara-Balgasun 37

Qara-Khitai Liao 22, 41, 150

Qara Noyan 58

Qara-Qorum 9, 20, 76, 77, 80, 83, 84, 85, $86,87,88,95,109,124,127,133,151$, 156

Qazvin 76, 124

Qipchak Khanate 39, 152

Qongqurtai 178, 179

qubchur 92, 111, 112, 115, 118, 119

Qubilai Khan 10, 147, 155, 178, 179, 204

Queen Tamar 33

Qutlughshāh 195, 197, 200, 201, 202, 204, 209

Quțuz 144, 146

\section{Rabban Sawma 182}

Rashīd al-Dīn 4, 8, 10, 26, 27, 28, 29, 45, $46,47,48,49,50,51,56,57,58,60$, $61,64,75,78,82,101,102,108,111$, $112,113,114,115,117,121,122,123$, $124,125,126,128,129,130,131,132$, $133,134,135,136,137,138,139,140$, $143,144,145,146,147,151,152,153$,
$155,167,168,170,174,175,176,177$, $179,180,181,183,184,185,187,188$, $193,194,195,197,198,209,216$

rebellion $27,74,91,92,96,119,153,178$, $181,197,210$

Richardus 173

Roman Church 173

Rome 65, 79, 173, 183, 205

Ŕubenids 34, 36

Rubruck 21, 30, 60, 62, 63, 73, 85, 87, 88, $89,95,123,127$

Rūm 16, 36, 43, 58, 60, 61, 63, 65, 67, 76, $79,83,84,88,89,90,122,124,125$, $127,131,135,148,151,170,173,179$, $184,186,213,223$

Sadun Artsruni 77, 78, 93, 96, 135, 166, 180,221

Samarqand 20, 121, 150

Samuel Anets'i 10, 18, 205, 208

Sarai 39, 101, 150, 154

Sasun 43, 103, 135

Sati Beg 210

Sayan Mountains 38

Sebastats'i 19, 20, 45, 51, 53, 54, 63, 64, $65,74,108,111,114,126,134,140$, $151,63,64,65,74,108,111,174,178$, $179,181,184,185,189,194,201$

Sebastia 19, 45, 63

Secret History of the Mongols 7, 100

Seljuks 43, 44, 62, 63, 76, 79, 89, 90, 92, $129,159,170,173,174$

Shahnshah $34,57,58,61,74,90,91,92$, 129, 166, 201

shahna 105,140

Shamakha 50, 60

Shamanism 38, 219

Shamkor 12, 48, 56, 57, 60, 102

Sheng-wu Ch'in-cheng lu 10

Shiramun 122, 166, 167, 180

Siwnik' 17, 18, 25, 34, 59, 60, 75, 76, 92, 93, 102, 197

Smbat Orbelian 17, 76, 77, 78, 92, 93, 95, 96, 221

Smbat Sparapet 5, 11, 17, 20, 21, 35, 66, $74,79,80,81,82,84,85,86,88,89$, $94,125,138,144,145,148,161,162$, $164,165,169,170,172$

Sogdian 7, 38

spitak 109, 113

Step'annos Episkopos 18, 19, 27, 44, 45, 48, , 49, 54, 55, 58, 61, 64, 94, 105, 
$108,110,134,169,170,177,178,179$, 181,183

Step'annos Orbelian 4, 11, 15, 17, 18, 25, $27,34,54,59,75,77,78,91,92,93$, $95,105,109,117,153,154,155,163$, $166,175,176,178,179,180,181,187$, $189,194,197,202,222$

Sübedei $24,42,45,46,47,48,49,50,52$, 72

submission $13,51,56,58,61,63,65,67$, $71,73,74,78,80,81,86,89,97,133$, $142,165,177$

Sultan 16, 20, 35, 46, 49, 53, 58, 60, 61, $62,79,83,85,90,94,133,134,136$, $140,144,145,147,148,149,160,161$, $163,164,165,170,173,176,177,178$, $179,181,182,184,186,187,189,194$, $195,198,199,200,201,203,205,206$, $211,212,213,225$

Sulțānīyya 204, 208, 209, 210, 213

Swanetia 25, 73, 90, 91

Syria 5, 13, 21, 29, 31, 36, 63, 89, 112, $121,122,124,132,133,135,136,137$, $140,141,142,143,144,145,146,147$, $148,150,153,156,157,159,160,164$, $167,170,171,172,173,174,175,187$, $188,190,195,199,200,201,204,207$, $217,221,224$

ṣaḥib-dīvān 78, 132, 177, 184

Tabriz 15, 17, 36, 45, 48, 51, 54, 109, 113, $140,143,160,176,178,184,185,189$, $194,197,202,210$

taghar 111, 113, 115, 118, 126

Taiji'uts 38,40

tamgha $101,103,114,115,116,118$

tamghachi 53, 101, 103, 104, 106, 114

Tangquts 22, 40

Ta'rikh-i Jahān-Gushā 28

tarkhan 117

T'at'arats' Patmut' iwn 15

Tatars $11,18,23,38,40,45,46,80,84$, 87,176

Taurus Mountains 34, 103

taxes 2, 26, 29, 35, 71, 80, 87, 92, 95, 99, $103,105,108,109,111,112,114,115$, $116,117,118,119,120,134,154,166$, $176,202,205,214,217,220,222$

Tegüder 25, 27, 124, 129, 156, 160, 167, $175,176,177,178,179,180,193$, 211
Temüjin 38,47

Tenggeri 196

Tiflis 15, 48, 51, 57, 90, 91, 105, 109, 117, $154,167,177,178$

Tigris 129,131

Toghachar 45,47

Tolui 39, 86, 121, 150

Toluids 8, 149, 151, 167, 223

Toqta 181,188

Tornikids 43

T'oros 138, 162, 205

Transoxiana 39, 42, 83, 100, 125, 150

tributes $2,26,33,88,99,118,120,170$, $182,217,220$

triplication 45

tuman $47,55,102,112,167$

Turkic Khanate 37

Turkistan 51

Turks $28,33,36,43,44,55,68,87,130$, 152,222

Tuul 37

Tyre 185, 188, 201, 207

Tabaqāt-i- Nāșirī 28

Uighurs 7, 28, 37, 38

Uighur script 7, 38

ulagh $113,118,126$

'ulamā' 123, 196

Utrār 42, 43

Vachutians 34, 92

Vahram Gagets'i 56, 74, 91, 94

Vahram Rabuni 11

Vakhtangids 167

Vanakan Vardapet 11, 14, 16, 17, 94

Vardan Arevelts'i 4, 10, 11, 12, 14, 15, 18, $27,44,45,48,49,50,51,53,54,56$, $57,58,60,63,65,74,76,85,91,92$, $95,108,111,119,125,127,130,133$, $134,135,137,144,155,156$

Vasil Tatar 74, 81, 94

Vaspurakan 25, 43, 103, 194

vassal $31,41,75,77,79,82,84,89,94,96$, $99,112,141,180,219$

Vașsāf 29, 101, 150

Vayots'-Dzor 34, 208

vazir 105

vilayet $102,103,107,120,167,179$

Western Turkestan 38

White Annals 9 
xalan 80

Xianbis 37

Xiongnu

Hunnu 37

yam 115, 118

yarghuchis 148

yarlikh 86

Yaroslav of Suzdal 83

Yasa 23, 152, 210

Yeke Monggol Ulus

Great Mongol State 38, 39, 219, 225
Yoshmūt 133, 134

Yüan Dynasty 39, 113

Yüan Shih 9, 10, 30, 50, 101, 113

Zabel

Isabel 36, 188

Zak'arē 33, 34, 57, 58, 74, 75, 78, 92, 129, 154

Zak'arids 13, 18, 33, 60, 75, 78, 90, 102, 166

Zafar-Nāma 124 



\title{
BRILL'S \\ INNER ASIAN LIBRARY
}

\author{
Editors \\ NICOLA DI COSMO \\ DEVIN DEWEESE \\ CAROLINE HUMPHREY
}

ISSN 1566-7162

The Brill's Inner Asian Library Series is dedicated to the scholarly research of every aspect of the history, literature, religion, arts, economy and politics of Inner Asian cultures and societies. The Series aims to contribute to the development of Inner Asian studies by representing also non-Western scholarly traditions.

1. Di Cosmo, N. and D. Bao, Manchu-Mongol Relations on the Eve of the Qing Conquest. A Documentary History. ISBN 9004117776

2. Williams, B.G., The Crimean Tatars. The Diaspora Experience and the Forging of a Nation. 2001. ISBN 9004121226

3. Levi, S.C., The Indian Diaspora in Central Asia and its Trade (1550-1900). 2002. ISBN 9004123202

4. Allworth, E.A., Evading Reality. The Devices of 'Abdalrauf Fitrat, Modern Central Asian Reformist; Poetry and Prose of 'Abdul Qadir Bedil. Transl. from Persian by William L. Hanaway. 2002. ISBN 9004125167

5. Gross, J. and A. Urunbaev, The Letters of Khwāja 'Ubayd Allāh Ahrār and his Associates. 2002. ISBN 9004126031

6. Atwood, C.P., Young Mongols and Vigilantes in Inner Mongolia's Interregnum Decades, 1911-1931. 2002. ISBN 9004126074

7. Rachewiltz, I. de (tr.), The Secret History of the Mongols. A Mongolian Epic Chronicle of the Thirteenth Century. 2003. ISBN 9004131590 (Set), ISBN 9004135960 (Vol. 1), ISBN 9004135979 (Vol. 2)

8. Elverskog, J., The 'Jewel Translucent Sütra'. Altan Khan and the Mongols in the Sixteenth Century. 2003. ISBN 9004132619

9. Muhammad- Sharîf-i Șadr-i Ziyā, The Personal History of a Bukharan Intellectual. The Diary of Muhammad-Shariff-i Șadr-i Ziyā. 2004. ISBN 9004131612

10. Dale, S.F., The Garden of the Eight Paradises. Bābur and the Culture of Empire in Central Asia, Afghanistan and India (1483-1530). 2004. ISBN 9004137076 
11. Amitai, R. and M. Biran (eds.), Mongols, Turks, and Others. Eurasian Nomads and the Sedentary World. 2005. ISBN 9004140964

12. Frank, A.J. and M.A. Usmanov, An Islamic Biographical Dictionary of the Eastern Kazakh Steppe: 1770-1912. 2005. ISBN 9004141278

13. Drompp, M.R., Tang China and the Collapse of the Uighur Empire. A Documentary History. 2005. ISBN 9004141294

14. Russell-Smith, L., Uygur Patronage in Dunhuang. Regional Art Centres on the Northern Silk Road in the Tenth and Eleventh Centuries. 2005. ISBN $900414241 \mathrm{X}$

15. Tighe, J.R., Constructing Suiyuan. The Politics of Northwestern Territory and Development in Early Twentieth-Century China. 2005. ISBN 9004144668

16. Newby, L.J., The Empire and the Khanate. A Political History of Qing Relations with Khoqand c. 1760-1860. 2005. ISBN 9004145508

17. Kakar, M.H., A Political and Diplomatic History of Afghanistan, 18631901. 2006. ISBN 9789004151857

18. Srinivasan, D.M. (ed.), On the Cusp of an Era. Art in the Pre-Kuṣāna World. 2006. ISBN 9789004154513

19. Subtelny, M.E., Timurids in Transition. Turko-Persian Politics and Acculturation in Medieval Iran. 2007. ISBN 9789004160316

20. Baumann, B., Divine Knowledge. Buddhist Mathematics According to Antoine Mostaert's Manual of Mongolian Astrology and Divination. 2008. ISBN 9789004155756

21. Forêt, P. and A. Kaplony (eds.), The Journey of Maps and Images on the Silk Road. 2008. ISBN 9789004171657

22. Donzel, E. van and A. Schmidt (eds.), Gog and Magog in Early Eastern Christian and Islamic Sources. Sallam's Quest for Alexander's Wall. 2010. ISBN 9789004174160

23. Kara, G. Dictionary of Sonom Gara's Erdeni-yin Sang. A Middle Mongol Version of the Tibetan Sa skya Legs bshad. Mongol - English - Tibetan. 2009. ISBN 9789004175792

24. Dashdondog, B. The Mongols and the Armenians (1220-1335). 2011. ISBN 9789004186354 